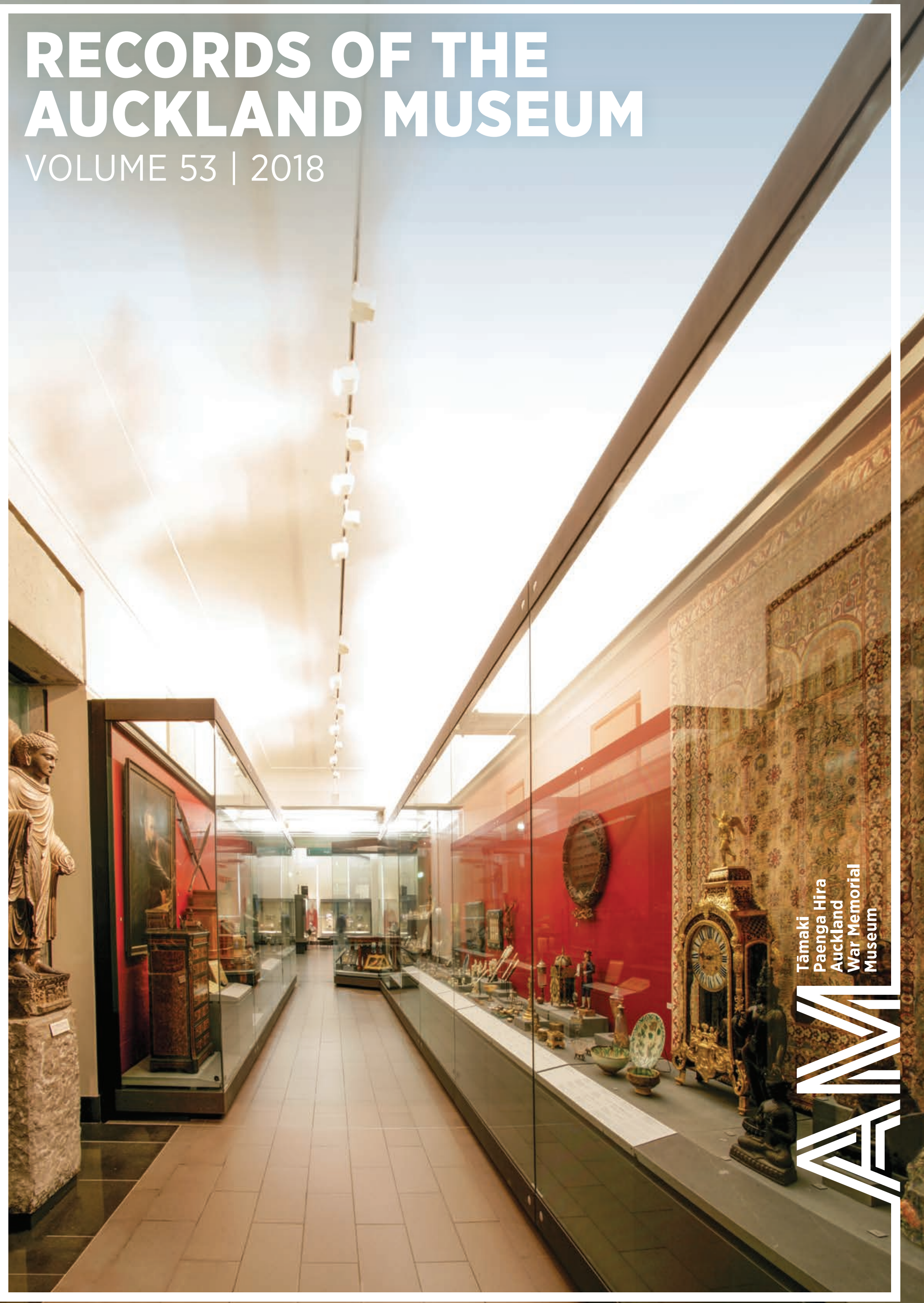




\section{Records of the Auckland Museum \\ Volume 53 | 2018}

Auckland, New Zealand, 2018. 
RECORDS OF THE AUCKLAND MUSEUM

ISSN 1174-9202 (Print)

ISSN 2422-8567 (Online)

In continuation of Records of the Auckland Institute and Museum

Volume 1, Number 1 (June 1930)

Published by Order of the Trust Board

Dr David GAIMSTER, Director

[Vol. 52 was published on 15 December 2017]

Editors

J.W. EARLY and L. FUREY

Production

L. FUREY

The Auckland War Memorial Museum has a statutory role to advance and promote cultural and scientific scholarship and research that is met in part by publication of the Records of the Auckland Museum. The Records have been published continuously since 1930. Issues are annual.

The Records contain the results of original research dealing with material in the collections of Auckland Museum, and research carried out by Museum staff members in their particular subjects. All papers are refereed. Instructions for authors are given at the end of this, or recent volumes. The Records are distributed, largely by exchange, to libraries at about 250 academic institutions-throughout the world. Proposals for exchange agreements should be addressed to the Auckland Museum Library Manager.

The contents of the Records are reported in Index New Zealand, Anthropological Index (Royal Anthropological Institute, London), Anthropological Literature (Harvard University), Biological Abstracts, Kew Record of Taxonomic Literature, Zoological Record and GeoRef (American Geological Institute). Vol. 34 contained indexes to the contents of volumes 1-33. Monographs are produced occasionally in the series Bulletin of the Auckland Museum (see website: Library Services/Museum Publications).

(C) 2018, Auckland War Memorial Museum. Private Bag 92018, Auckland, New Zealand www.aucklandmuseum.com

Cover image: The Mackelvie Gallery, Auckland War Memorial Museum. Photograph by Krzysztof Pfeiffer. 
Records of the Auckland Museum

\section{Volume 53 | 2018}

\section{Table of Contents}

\section{Articles}

'A matter of duty': the Egyptian collection at the Auckland War Memorial Museum Joshua Emmitt \& Louise Furey

Preserving a legacy: an analysis of the role and function of the Mackelvie Trust Board, 1885-2010

Andrew McKay

'Your list is certainly a formidable one': the Rev. A.H. Voyce and the Auckland Museum Moira White

The plants of Waya Island, Fiji

Rhys O. Gardner

Charles De Kempeneer (c.1852-1884), preparator: one of Auckland Museum's earliest employees

B.J. Gill 



\title{
'A matter of duty': the Egyptian collection at the Auckland War Memorial Museum
}

\author{
Joshua Emmitt School of Social Sciences, Faculty of Arts, University of Auckland \\ Louise Furey Auckland War Memorial Museum
}

\begin{abstract}
The Auckland War Memorial Museum houses nearly 2000 Egyptian artefacts dating from the Palaeolithic to the modern era. Artefacts were obtained from professional institutions and societies including Cairo Museum, the Egypt Exploration Society, and the British Museum in the early 20th century. In addition, a number of objects were obtained from 'soldier collectors' during World Wars I and II. The collection is made up of objects from around Egypt, but mainly consists of collections from Amarna, Saqqara, Kharga, Abydos, and Matmar, amongst others. Here the history of the collection is examined.
\end{abstract}

\section{Keywords}

Egypt; soldier collectors; Egypt Exploration Society; history of museum collections; Fred Waite; archaeology.

\section{INTRODUCTION}

The acquisition history of the Egyptian archaeological collection in Auckland Museum mirrors that of other large museums in New Zealand which sought to increase their holdings of material for purposes of display and education. The majority of the acquisitions were small, peaking in the years of WWI and WWII, and immediately after. In the intervening years the museum also acquired material from institutions in Egypt and England, and in some cases targeted objects from specific periods of Egyptian history, based on the shifting interests of the curators and directors over time, and the goal of having a "representative" collection.

This paper has been developed out of a Collection Readiness project to make the museum collections more accessible and to improve the descriptions of items in the Egyptian collection. Previously uncatalogued material was also described and records created, and records for Egyptian items in the archaeology collections increased from 1436 to 1918. Many objects have been imaged and the records are accessible online: http://www. aucklandmuseum.com/discover/collections. In addition, research was carried out into the internal provenance of many of the items obtained from known archaeological excavations. An earlier study of the history of the collection (Bol 2006) was drawn on and expanded with research into provenances of individual objects.

Since 1983 the removal of objects from Egypt has been restricted to only those authorised by the Antiquities Service. This directive has affected museums and fieldwork research teams around the world, for example the Petrie Museum of Egyptian Archaeology (Stevenson and Challis 2015), but during the late 19th and early 20th century thousands of artefacts were distributed from foreign-led projects to institutions, museums, and individuals around the world. A research project entitled Artefacts of Excavation has traced many of the Egyptian artefacts sent by British institutions to local and global museums between 1880 and 1980 (Stevenson 2014; Stevenson et al. 2016). This project has provided data on where specific objects are now, resulting in an online database of object destinations and guides relating to the distributed material (egyptartefacts.griffith.ox.ac.uk). The project has helped establish the original contexts of many of the objects in the collection of Auckland Museum, much of which were unknown due in part to the lack of published data from sites at the time of object distribution. In addition to the professional sources, a small but significant component of the collection was obtained by New Zealanders who were stationed in Egypt during WWI and WWII.

The Egyptian collection in the Auckland War Memorial Museum spans a time period from the Palaeolithic through to the modern day, and come from around the country, but primarily from the Nile Valley (Fig. 1). The Annual Reports of Auckland Institute and Museum from the 1870s and 1880s list the few Egyptian acquisitions received from well-known Aucklanders including L.D. Nathan, James Russell, and John Logan Campbell. Many of the wealthy individuals of the time undertook 'Grand Tours' of Europe and the 


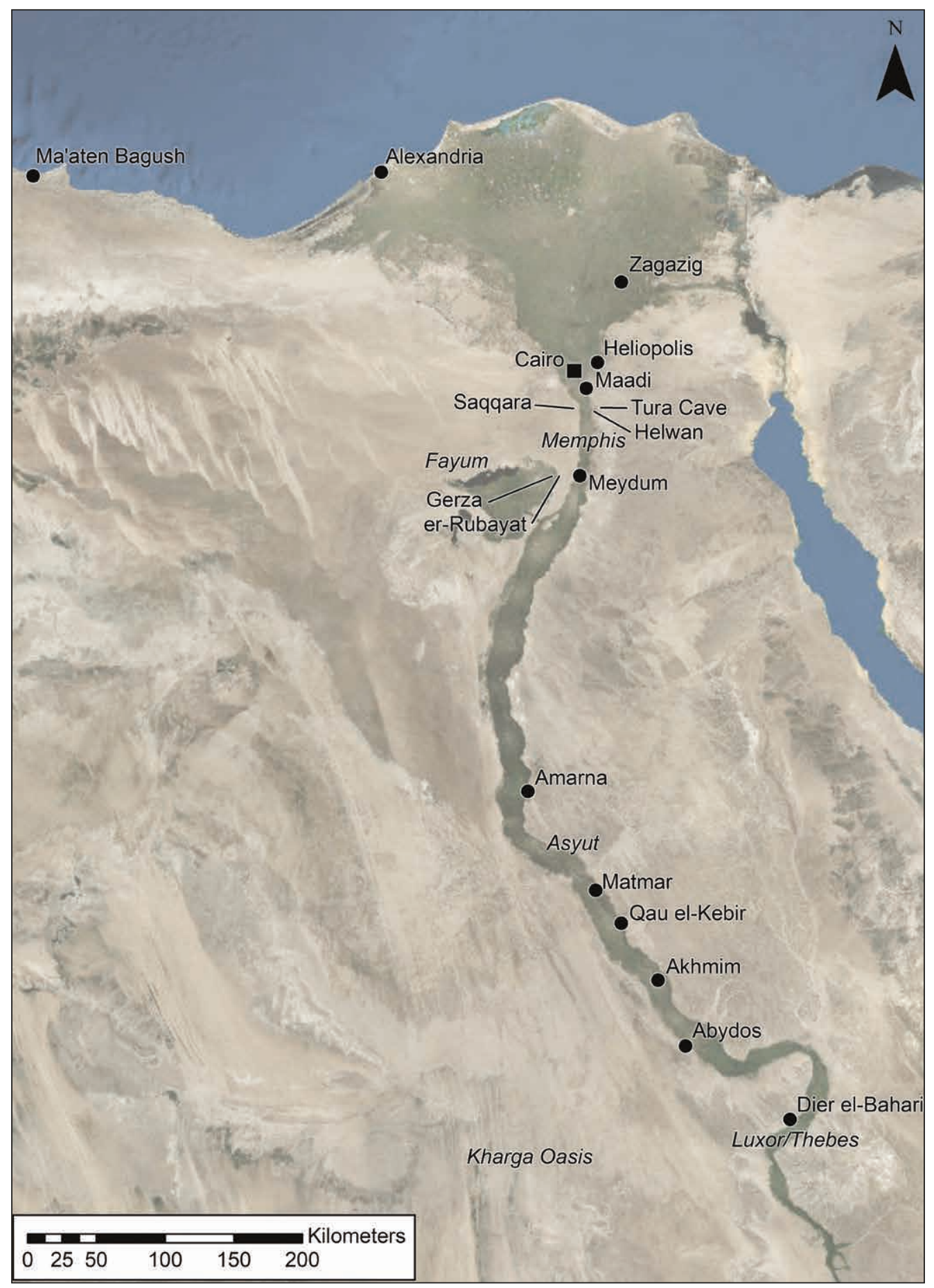

Figure 1. Map showing provenance of objects in the Auckland Museum Egyptian collection.

Mediterranean, returning with objects and curios to decorate their residences and to donate to institutions such as Auckland Museum. For instance, Logan Campbell's gifts to the museum in 1877 included beads and a kohl pot (Hamilton 2015). Thomas Cheeseman, Curator of Auckland Institute and Museum from 1874-1923, actively sought to increase the collections of the museum by corresponding with individuals and overseas institutions and arranging exchanges of surplus objects of New Zealand origin for new items to increase the diversity of the museum's collections. One such arrangement, with Professor Enrico H. Giglioli of Florence Museum, resulted in the acquisition of a mummy in 1896, which is discussed further below. Cheeseman also solicited objects, such as his request to the director of excavations at Beni Hasan, upon reading in a periodical that there was surplus pottery available for museums (letter, Cheeseman 5 April 1904). No items were received and a reply to Cheeseman's letter has not been found. 


\section{CAIRO MUSEUM}

Prior to 1914 the museum had a small Egyptian collection. This changed after the start of WWI when the New Zealand Expeditionary Force (NZEF) was based in Egypt for further training prior to being sent to Gallipoli. The museum acknowledged public interest by seeking to expand the Egyptian collection:

"The active and historical part taken by the New Zealand Expeditionary Force in Egypt has attracted the attention of the Dominion to that country, and for many years will continue to do so. Under these circumstances, the Council considers that it is almost a matter of duty to commence the formation of a small Egyptian collection, which to a certain extent will allow the citizens of Auckland to personally inspect some of the remains of the oldest known civilisation. Negotiations were consequently opened with the Gizeh Museum at Cairo, and a collection of over 70 articles has been obtained... If circumstances permit, the Council hopes to gradually follow up this beginning by future consignments." (Annual Report of the Auckland Institute and Museum 1916-1917: 11)
Thomas Cheeseman initiated correspondence with James Quibell, Keeper at Cairo Museum 1914-1923 (Bierbrier 2012: 450), after an introduction by Dr A. Challinor Purchas, medical officer with the NZEF (Auckland Star, 29 January 1918; New Zealand Herald, 30 January 1918). Auckland Museum sent 10 Egyptian Pounds (LE) to Cairo Museum, with Cheeseman requesting as many objects as the sum would buy. Until 1970 Cario Museum had a sales room where objects from excavations could be bought (Piacentini 2011). Quibell in a letter to the Cheeseman (31 January 1916), pre-empted what he saw as predictable questions such as "Why do you not send me a list of objects on sale and let me pick what I want?" to which he answered his own question by saying "it would be difficult to hold [objects] back for the necessary time. Good things sell like hot cakes". This highlights one of the issues of being so far away as correspondence could take months or more, and the market that the dealers of objects were operating in was of a faster pace. In addition, the correspondence was occurring in the context of World War I, which would cause other issues for the shipping of the objects.

The material sent to Auckland is described briefly in the Annual Report of the Auckland Institute and Museum for 1917-1918: 9. The consignment consisted of "about"

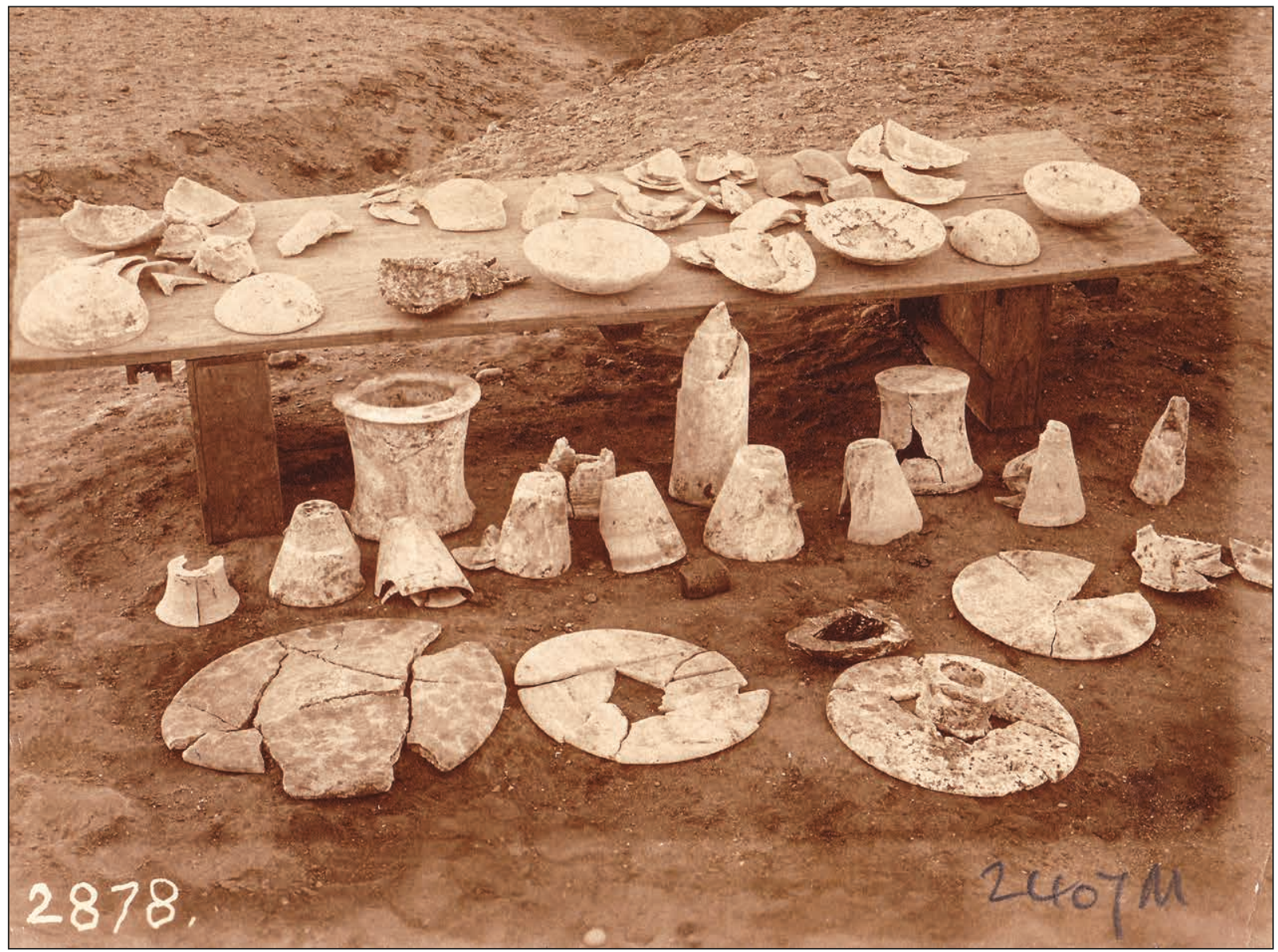

Figure 2. Alabaster vessels from Mastaba 2407 after excavation. The objects in the figure are now in the Auckland Museum collection. Photo 2878 copyright Università degli Studi di Milano, Egyptological Library and Archives, Quibell Collection (Orsenigo 2017). 
100 artefacts, with the "most interesting" being a series of vessels excavated by Quibell at Saqqara. While the Annual Report would suggest that the acquisition was routine, the consignment was delayed by some months due to an unspecified hold-up at the Suez Canal. In addition, an Australian Maritime Strike in 1916 delayed both mail communication to New Zealand and the objects themselves (letter, Cheeseman 1918). The objects eventually arrived in good order and were immediately put on display in a dedicated cabinet in early 1918.

The material from Saqqara was from Mastaba (tomb) 2407 , located south of the Teti Pyramid and was excavated between the years of 1910 and 1914 (Fig. 2) (Quibell 1923). In the correspondence between Quibell and the museum there is no mention of age of the items from Saqqara, and the original consignment sheet has not been retained. In the newspaper account, the Annual Report for 1917-18, and ethnology register, the objects are attributed to an 11th Dynasty tomb. In the later publication of the excavation however, Quibell (1923) attributed the tomb to the late second or early third dynasties, and comparison of vessel forms with others from the period (Aston 1994) would support this attribution. This error possibly occurred if the consignment note accompanying the objects stated "II Dynasty" as it is the custom to write dynasty numbers in Roman numerals, which was then transcribed as 11 th dynasty.

In addition to the Saqqara material, 52 of the objects received from Cairo Museum were from other locations. These included a canopic vase, cloth with hieroglyphic writing, amulets, ceramic vessels, statuettes, and ushabti figures. The pieces are what could be described as "odds and ends" as none of them form an assemblage from a single excavation, but they did provide the museum with a wide range of material culture from Egypt that could serve as the foundation for a larger collection. Of the more curious objects obtained, three samples of "mummy wheat" were sent from a tomb at Deir el-Bahari attributed to the 20th Dynasty. No direct provenance information for the wheat samples is possible, but based on the attribution to the 20th Dynasty and Dier el-Bahari, it is possible that the samples originated from Theban Tomb 320 (also referred to as DB320) (Reeves and Wilkinson 1996: 194-6). Mummy wheat itself has a complex history, and the term had several uses including wheat found inside of mummies, or found in tombs, including inside miniature granaries. In some cases cultivation of samples was attempted, with no success (Moshenska 2017).

\section{THE EGYPT EXPLORATION SOCIETY AND BRITISH EXCAVATIONS IN EGYPT}

After the acquisition of material from the Cairo Museum, attention was directed to obtaining artefacts through the Egypt Exploration Society (EES). During the early 20th century there were extensive ongoing excavation projects throughout Egypt, following the tradition of archaeological investigations which started in the mid-19th century. A key participant in some of these excavations was the Egypt Exploration Society (founded in 1882 as the Egypt Exploration Fund, and the name was changed in 1920). The Society carried out archaeological excavations and funded the work by having institutional members who paid a subscription or made a monetary donation. In exchange surplus objects were sent to the subscribing institutions, or to institutions in proximity to subscribing members. The system worked very well for museums worldwide which otherwise would not have the opportunity to acquire items, and they were able to obtain genuine artefacts for their collections. The amount paid by each subscriber varied, and the number of artefacts received was commensurate with the subscription amount. Several New Zealand museums subscribed to the society. For several years Auckland Museum purchased from EES a subscription to the Journal of Egyptian Archaeology, and in 1924 the society was approached for an artefact subscription service. Beginning in 1926, a $£ 10$ subscription was paid on an annual basis.

The first consignment of 22 objects was received from the 1925-26 excavation of Abydos (accession no. 1926.225). This excavation was of burial contexts dating from the Predynastic to Ptolemaic periods. Thirteen of the objects were beads or necklaces, which prompted a request from Cheeseman for objects "other than beads" to be sent the following year (letter, Jonas 1927). One object of note from this acquisition was a large fragment of a greywacke palette with a falcon head (10429) (Fig. 3). This palette is of a fine finish and is attributable to tomb 1636 at Abydos, in which was also found five ceramic vessels (Egypt Exploration Society: AB.TC.25-26.1636). Animal shape palettes are common in Predynastic contexts, particularly those attributed to the Naqada I and II periods, as the form declined from Naqada III onwards (Stevenson 2009). The falcon headed palette is not an uncommon form, but rather the thickness (18 mm), and general size (L: $243 \mathrm{~mm}, \mathrm{~W}: 120$ $\mathrm{mm}$ ) of the artefact make it one of the larger examples.

From the 1926-27 season onward material was received from excavations at Amarna (accession no. $1928.40 ; 32$ items). The following year, 1927-8, there was no EES expedition to Egypt due to a lack of funding, and therefore no material distributed to the subscribing institutions (letter, Jonas 1928). Instead, the museum received a plaster cast of the bust of one of the daughters of Akhenaten (Fig. 4), with the original (which was retained by the Cairo Museum) published by Frankfort (1927: LIII). Copies of the bust were sent to several institutions that year in lieu of the usual range of artefacts (Records of Excavation: DIST.51.21). The following year excavations resumed at Amarna, and material was sent to Auckland from the 1928-29 (accession no. $1929.340 ; 21$ items) and 1930-31 (accession no. 1932.34; 27 items) seasons. Many of the letters sent by Auckland to acknowledge receipt of items requested more information about the objects. Brief descriptions were provided but it was stressed that information about particular objects was difficult to provide. The results of the relevant excavation at Amarna were not published until later, when Frankfort and Pendlebury published their The City of Akhenaten series; volumes two (Frankfort and Pendlebury 1933) and three (Pendlebury 1933 ) include reference to material sent to Auckland. 


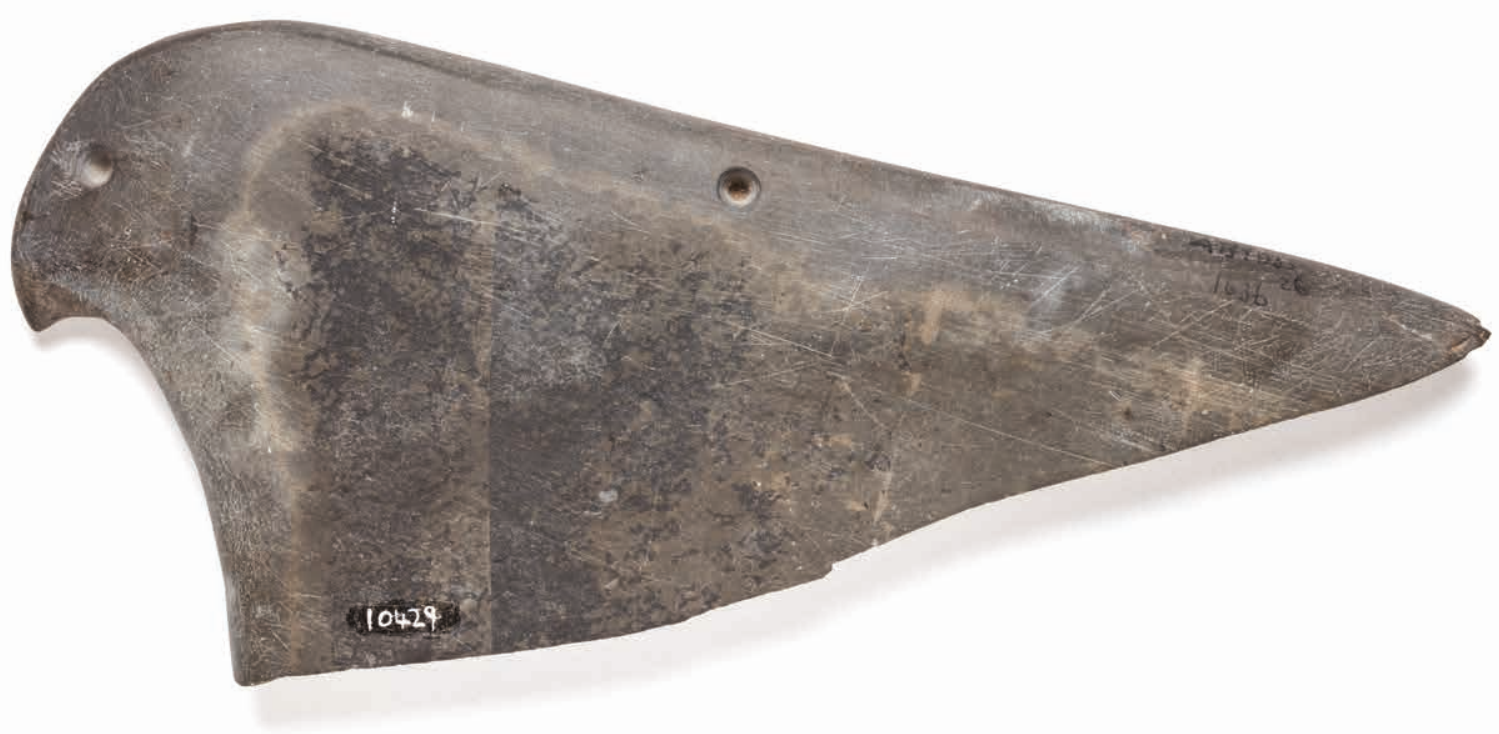

Figure 3. Palette from Abydos 1925-1926, tomb 1636. Auckland War Memorial Museum. 1926.22, 10429.

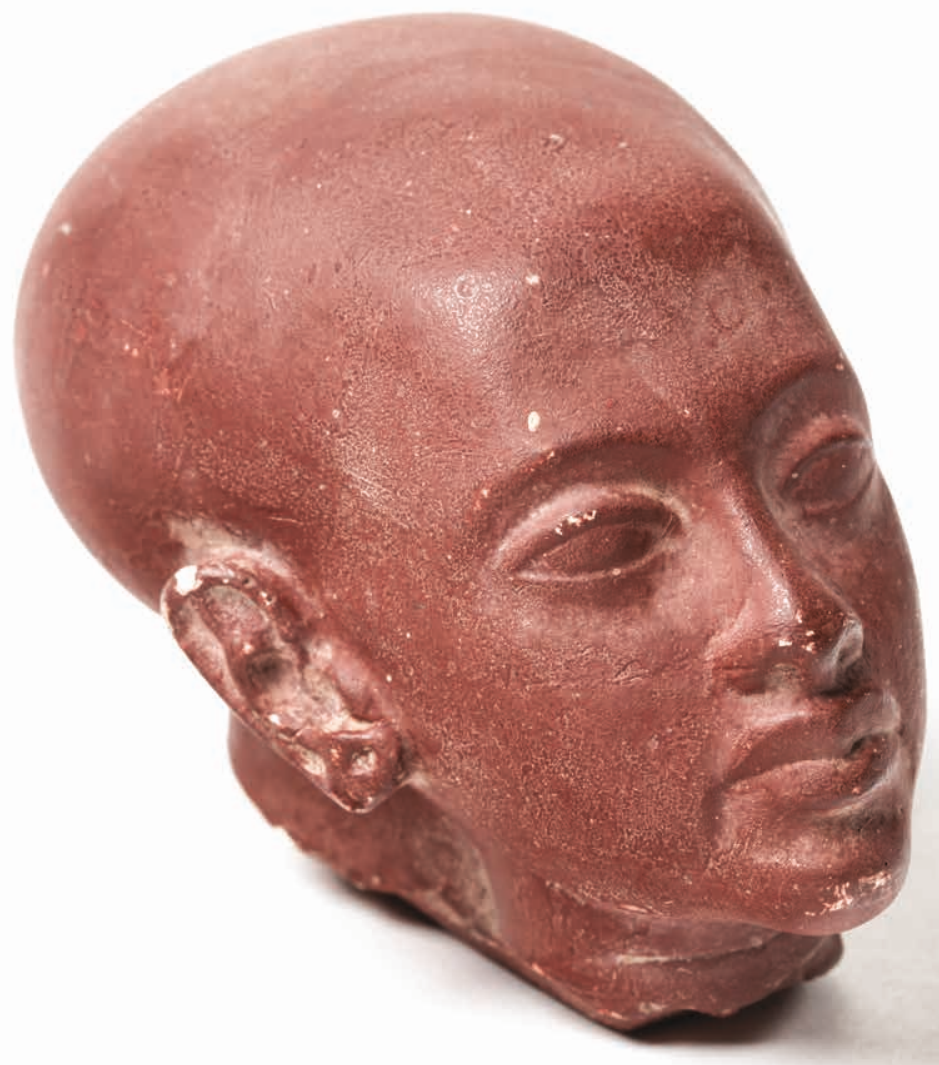

Figure 4. Plaster cast of the bust of a daughter of Akhenaten. Auckland War Memorial Museum. 1928.6, 1389. 
Amongst the material obtained from the EES from Amarna were large blue-painted vessels (Fig. 5). One of the vessels (2013.x.40) is marked 24/223 which implies it is from the 1923-24 season at Amarna and was distributed to the museum in 1926 (C. Hamilton, Monash University, pers. comm. 14 January 2014). The vessels are among those repaired by W.H. Young of the Ashmolean Museum (letter, anon. 1925-26). According to the EES distribution lists, Auckland should have only received one of the blue-painted vessels from the 1926-1927 field season (Egypt Exploration Society: DIST.REG.03). It seems that an error on the part of the EES meant that a vessel meant for the Dominion Museum in Wellington was sent to Auckland, as well an additional one. These vessels sat uncatalogued in the museum collections until 2013.

The final acquisition from the EES to Auckland was in 1935 (1935.260; 28 items), as the subscription was suspended from 1932 to 1934. The reason for this is unknown, but it may have had something to do with the lack of material sent from the 1931-1932 season and a corresponding lack of communication from the EES (letter, Archey 7 May 1935). A final payment of $£ 10$ was made in 1935, and in return some faience objects from Deir el-Bahari were sent, along with two ushabti and one string of beads of unknown provenance. Gilbert Archey, Director of Auckland Museum at the time, in correspondence to the EES (letter, Archey 7 May 1935) was unsure if funds could be secured to continue the subscription to the society, and no further items were received from the EES after that year.

Meanwhile Archey was pursuing other avenues for acquiring objects. An approach was made to the British Museum in June 1932 for duplicates of Roman and Greek objects. The response was negative but the offer was made that "some early Egyptian Antiquities may shortly become available, and if any of these would be desirable for your Museum a small selection could be reserved" (letter, British Museum 30 June 1932). At that time Guy Brunton was excavating at Matmar, and the British Museum likely put Archey in direct communication with Brunton, although the introductory letter from Archey requesting assistance with purchasing particular objects to the value of $£ 10$ has not been located. Archey’s request for material from a specific period of Egyptian history, the Predynastic, suggests the museum, for the first time, was assessing the Egyptian collection and seeking to fill in the gaps. Gertrude Caton-Thompson, a colleague of Brunton, advised Archey that no suitable objects were to be found at the dealers in Cairo, and offered to provide items from Brunton's excavation at Matmar which were stored in the over-stocked British Museum (letter, CatonThompson 1932a). Auckland Museum sent a payment of $£ 10$ and in return received nine vessels and some beads from tomb 5109 at Matmar (letter, Caton-Thompson 1932b; Brunton 1932a) (18727 - 18737). These eleven objects are erroneously identified in Auckland Museum's accession register (1932.558) as being purchased from the British Museum. The Matmar excavation was carried out under the auspices of the British Museum, which had the first choice of objects, but as Brunton had organised funding of the four excavation seasons (1928-31) himself, the remaining items were owned by Brunton and were his to distribute (letter, Brunton 1932b; CatonThompson 1932c). However, packing and freighting was facilitated through the British Museum due to Brunton's travel commitments (letter, Brunton 1932a). A total of 92 objects were provided by Brunton (1932.559), dating from the Predynastic to the Coptic periods, and as he noted to Archey (letter, Brunton 1932b), they were worth more than the payment made. Also included were alabaster vessels, scarabs, and beads dating to primarily the First and Second Intermediate Periods. The distribution of objects to Auckland Museum is noted in the publication of the excavation (Brunton 1948).

The final group of artefacts obtained from British excavations in Egypt came from Caton-Thompson in 1937. At this time Caton-Thompson was working on the publication from her survey and excavations of prehistoric material from Kharga Oasis, which occurred between 1930 and 1932. Due to the time required to draw the relevant artefacts, and the expense involved, the publication of Caton-Thompson's work at Kharga Oasis did not occur until 1952 (Caton-Thompson 1952; 1983: 154-5). None of the artefacts sent to Auckland Museum are depicted in the final publication, whether this is because they were shipped before drawing or that those artefacts were just not included, is unknown. The material sent by Caton-Thompson consists of 92 Palaeolithic stone artefacts from Kharga Oasis, and originate from KO20 and related locales. In a letter to Archey, Caton-Thompson (1936) alluded to sending a second box of material that would contain Neolithic material was well as pottery; however, this second box never eventuated.

\section{SOLDIER COLLECTORS}

The Egyptian collection also benefited post-WWI from donations from soldiers and their relatives. Donors names carried their military title such as Major Guy Cheeseman (son of Thomas Cheeseman) and $\mathrm{Dr}$ A. Challinor Purchas (17 items) who served as a surgeon in Egypt during the war. Items from each donor were generally small in number and also scale, able to be carried in kitbags as souvenirs. Items included beads, ushabti, figures, small pots and mummified animals. Notable donations after WWI included 48 objects by W.H. Gummer, architect, who had not enlisted to fight, but was in England from 1908-1912 where there would have been opportunities to acquire the small objects including figures, small bronze boxes and scarabs (Lochhead 1998). The collections also benefited from the gift of Rev. Angus MacDonald, chaplain to the armed forces in Egypt, who donated 24 objects in 1925: 16 items were purchased from Cairo Museum, and others acquired "mostly in the neighbourhood of the pyramids", at Saqqara and Memphis. This was the first collection by a private individual with some indication of where the objects were obtained beyond a general 


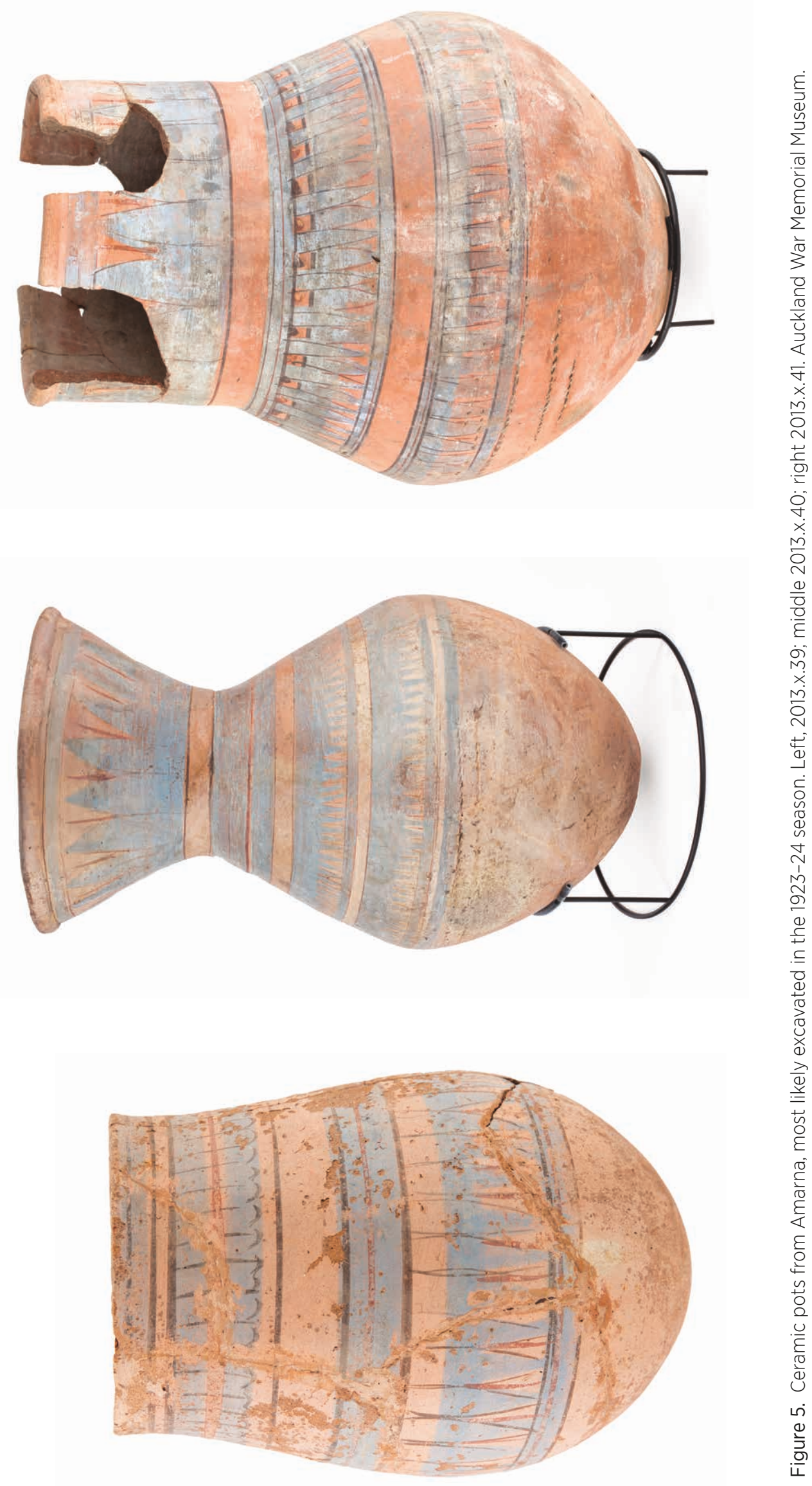


Egypt attribution. Another large collection of 43 items was donated by the widow of Charles Mackesy who reached the rank of Lieutenant Colonel. Sent to Egypt, then Gallipoli in 1915, he returned to Egypt for the remainder of WWI to take charge of the New Zealand Mounted Rifles Brigade (Green 1996).

While New Zealanders also served in Egypt during WWII, the subsequent donations of material to the museum were few in number, with a notable exception of the large collection made by Colonel Fred Waite. During both wars New Zealanders were primarily camped at Maadi, but were also stationed in the Libyan Desert and the Mediterranean coast, along with smaller camps in the greater Cairo area. During leave, soldiers were free to travel around Egypt as they could, and most spent their time in Cairo (Hedley and Hutching 2009). The objects collected represent the range of tourist trinkets that would be expected from any tourist to the country. However, opportunities were taken by some to carry out their own digging. For example, two bead necklaces [51224.1 \& 51224.2] collected by Mr Moller during World War I were accompanied by an account:

\footnotetext{
"Beads from Zeitoun, Egypt. I dug these up in the old city of On [Heliopolis] just outside our camp in Zeitoun in Dec 1914... A mate of mine Jack Heasberry and I got shovels from the quarter-master and started to dig. We struck a wall for a start and then got inside it, and found a tomb... We were stopped by two officers who told us a French syndicate has the rights for excavating there, so we stopped."
}

Other material collected by soldiers was less conventional, with rocks and sand from near the pyramids forming part of the collection. In addition, there are several pieces of polished granite said to be from the pyramid of Khufu at Giza and some limestone fragments from the top of the Sphinx. While some of these artefacts are likely genuine, most originate from the numerous stalls that sold "authentic" Egyptian artefacts to foreign troops and visitors.

The majority of material brought home by soldiers in the war came in the form of small isolated items. The exception to this is a collection of 152 stone artefacts, originally identified as from "Bargush", being an English phonetic spelling of Ma'aten Bagush, which was also known as Baggush Box, a transit camp and fortification during WWII on the Mediterranean Coast east of Mersa Matruh (Fig. 1). This material consists of stone flakes collected from the general area around the camp. Little is known regarding the collection beyond this, and it is currently under investigation.

After World War II donations of material from soldiers or soldiers' families came in over a period of time. Often items were part of personal effects or material bequeathed to the museum. Like the acquisitions following WWI, these offers tended to be small items such as bead necklaces, scarabs, and ushabti figures, some of which were genuine and others were not. Bead necklaces tend to be composites of mismatched beads from different periods, possibly assembled by vendors.
Again, military titles predominate in the acquisition information, for instance, Sgt. R.A. Scobie who worked at the museum as the education officer before and after the war, Gunner Laurie Birks, and Driver W.S. Baxter.

\section{COLONEL FRED WAITE}

One individual in particular made a notable contribution to the museum Egyptian collection. Colonel Fred Waite (1885-1952) was born in Dunedin and worked at the Otago Daily Times as a compositor. He enlisted in the NZ Expeditionary Force in 1914 as a lieutenant, served in Gallipoli where he won the DSO for gallantry and returned to New Zealand in 1916 where he became an instructor at NZEF training camps. He returned to civilian life after the war but during the second World War, as Lieutenant Colonel Waite, became the overseas commissioner for the National Patriotic Fund Board and was stationed in Cairo from 1941-44. He was then promoted to the rank of Colonel. It was during this period he was able to amass a number of artefacts. On his return to New Zealand he donated a large number of them to Otago Museum and became honorary keeper of Middle Eastern Archaeology (Green 1998). He published a volume on Predynastic pottery (Waite 1950), which received positive reviews internationally (Clark 1952).

Waite also had opportunities to collect Egyptian material during WWI and gifted it to Otago Museum. During his second secondment to Egypt during WWII, he collected substantially more material which Otago was also the beneficiary of but also gifted items to other main museums in New Zealand.

Whilst in Egypt Waite employed a soldier named Keith R. Collins, who was injured while on tour in Crete and did not want to be sent home as he was to marry an Egyptian woman (Collins 1952). Collins operated as a driver for Waite and helped to pack antiquities that were being sent back to New Zealand. Collins' wife, Heda, was the daughter of an Egyptian doctor who knew many archaeologists in Egypt and passed these connections through to Waite (Collins 1952). He was introduced to Zaki Saad, who was at that time the Chief Inspector of Saqqara and Giza, and was excavating at Saqqara (Bierbrier 2012: 481). It was from Saad that Waite likely obtained the alabaster vessels from Saqqara he donated to the Auckland Museum in 1943. In addition, Waite knew Flinders Petrie, Walter Emery, and Guy Brunton, all eminent scholars in the early 20th century (Skinner 1952). His connections ran higher as well, with King Farouk gifting him one hundred vessels from Helwan, now distributed throughout New Zealand museums, including Auckland (Skinner 1952).

The willingness of Waite to obtain material for New Zealand museums was first communicated through E.H. McCormick (letter, 23 April 1942), in which he forwarded a circular prepared by Waite (1942) offering to purchase items himself for donation to museums, but if a museum wished to obtain a particular item then money for the purchases would have to be provided. The museum director Gilbert Archey, who was himself away at war during WWII, knew Waite personally, which 
may have been a contributing factor in Waite sending material directly to Auckland Museum in 1942.

The majority of material obtained by Waite was of Predynastic origin as he had a particular interest in the period, at one time stating that he would "hate to venture into the ramifications of the Egyptian dynasties" (Waite 1942). In particular stone artefacts were sent in large quantities, as Waite (1942) highlighted in his circular "Flint stuff I can get in plenty, as no one wants it nowadays". Waite knew many of the dealers in Cairo and was the first to accompany any groups who were going into the desert and might come across antiquities (Bowie 1952). With dealers he had a "no questions asked" policy as to how the objects came into their possession (Bowie 1952).

During the 1930 s and 40 s there was a widespread trade in forged antiquities for sale to tourists, expanding on the previously established trade of high-end forgeries for the European market (Fiechter 2009). Waite (1942) was confident of his ability to avoid purchasing forgeries: "I have made some study of the modern village factories that now manufacture antiques, and think I can avoid the many clever copies now made for museums and tourists. I am also in touch with experts who can detect this modern material". Talking to one of the Egyptians selling cheap antiquities to the soldiers, Waite (undated) found that the man's father and uncle had both dug for Flinders Petrie, and now owned the land which the city of Memphis is situated on. Waite learnt that the men guarded the site for the Antiquities Service who were conducting excavations there, but also carried out "excavations" of their own, for sebakh (organic material used for fertiliser) and antiques, which they sold. Through these two men Waite was introduced to more antiquities dealers who sold real and fake objects, and with their advice, as well as that of Saad, and Raschid Bey of the Arabic Museum, was able to avoid forgeries.

Waite's collecting initially favoured Otago Museum, and he states in his circular, "Originally I set out to collect for the Otago University Museum, and of course my best stuff will go there, but there are many interesting duplicates" (1942). Once Waite learned of the wider museum interest for Egyptian antiquities, he approached all of the main New Zealand museums, including Auckland (letter, McCormick 1942). Auckland Museum received two consignments of material directly from Waite in 1942 (1942.106; 226 items) and 1943 (1943.84; 47 items) plus a few other items that were catalogued some years later as 'stock'. The Dominion Museum also received objects directly from Waite in 1943 (Oliver 1943 ) but also from Otago Museum the same year.

The final acquisition of Waite material was obtained by way of Otago Museum in 1946. Difficulties in transporting objects from Egypt to the different New Zealand museums prevented Waite from sending material directly to them (Skinner 1952), and instead he sent it all to the Otago Museum from where it was to be redistributed. As a result directors of other museums, including Auckland, were invited by H.D. Skinner to visit and make their selection.

Archey visited Otago Museum in 1946 and made his selection $(1947.49 ; 261$ items $)$. While the majority of the items were directly from Waite, there were also 91 objects catalogued by Otago Museum from 1943-1946 which Waite had previously gifted, and four objects which can be attributed to other sources. Skinner (1946), in a letter to Archey, insisted that the items were to be documented as a gift from Otago Museum, not Waite, contradicting a newspaper article in which Archey acknowledged the generosity of Waite (Otago Daily Times, 31 July 1946), and the Auckland Museum accession register attributes all of the items to Waite 'per Otago Museum'.

In total Auckland Museum received 546 objects which can be attributed to Waite. As mentioned, Waite had an affinity for Predynastic material, including stone vessels, slate palettes, and pottery. Reflecting Waite's (1942) comment that flint objects were easily obtained, 203 of the objects sent were stone artefacts, mostly of flint, and in the form of adzes and points. Much of the pottery sent includes the black-topped variety, one of which has an unusual potmark (Emmitt and Hellum 2015). Twenty-one of the Helwan vessels dating to the first dynasty, gifted to Waite by King Farouk, were also donated to Auckland, as were a large collection of lamps from the Greco-Roman period. Waite (1942) stated in his original circular that they were "easy to collect". Auckland Museum also obtained 30 ushabti figures attributed to Memphis.

Waite also gave objects to individuals, some of which eventually made their way to Auckland Museum. For instance, 10 Predynastic pots and Greco-Roman lamps were given to John William Kealy after WWI and donated by his widow in 1981. Kealy was also in Egypt during WWI where he met Waite. He also had a long association with Auckland Institute and Museum and was on the Council from 1939-1967, presiding as President from 1955-57 (Annual Report of the Auckland Institute and Museum 1970-71: 11).

\section{OTHER NOTABLE ACQUISITIONS}

There are two human mummies in the collection. One is an adult female, and the other a young boy. More is known of the history and health of the adult female.

The first mummy to be obtained was that of a boy. Thomas Cheeseman (letter, 19 September 1877) regularly corresponded from 1877 with Enrico Hillyer Giglioli, Director of the Florence Natural History Museum in Italy (letter, 23 November 1877; Gill 2010), and they exchanged objects for their respective museums, including plants, animals, and ethnographic items. Cheeseman (letter, 17 June 1895) askd Giglioli to find him "...A really good Egyptian mummy..." for the new Anthropological Hall on the Princes Street site. In 1896 the mummified body of a boy in an open wooden coffin arrived in Auckland, but Cheeseman's acknowledgement of its arrival (letter, 12 October 1896) expressed his disappointment: "I am very pleased indeed to have the Egyptian mummy although of course I should have liked the mummy of an adult better than that of a child. Nevertheless it is very acceptable, and perhaps another opportunity may occur to obtaining a larger specimen." 
The arrival of the mummy was briefly acknowledged as "mummy in its original wooden case - exchange from Prof H.H. [sic] Giglioli, Florence" but there was no further elaboration (Annual Report of the Auckland Institute and Museum 1896-97:15). There are no relevant letters from Giglioli related to the history of the mummy and attempts to trace the correspondence from Giglioli to Cheeseman has been unsuccessful (B. Gill, pers. comm.).

Cheeseman persisted in his attempts to acquire another mummy. In a letter (15 June 1916) to Quibell, he also asked, unsuccessfully, for assistance with obtaining one:

\footnotetext{
"Can you tell me what it would cost to obtain a really good mummy with its chief adjuncts. We have an inferior one at present, but if we obtain further articles through you, which I hope will be the case, I should like to have one which would be more satisfactory."
}

The boy mummy was not put on display until 1929 when the current building in the Auckland Domain was opened, and he remained in the public gallery space until 1969 when he was put into storage due to the poor state of preservation.

Examination by Eric Young (ex-Associate Curator at the Metropolitan Museum of Art in New York) in 1971 indicated the boy was probably six or seven when he died and dates to the 4th century BC based on stylistic elements of inscriptions on his wrappings. A Greek influence can also be interpreted which may mean he came from the Memphis region. Unfortunately, there is no extant copy of Young's report and information has come from a newspaper article of 1971 (New Zealand Herald, 14 January 1971).

An adult mummy was finally obtained in 1957 from Canterbury Museum in exchange for a coconut grater, a head rest from Tikopia, and a drum from New Guinea. The mummy did not rate a mention in the Annual Report, and she was not accessioned until 1986. The female mummy was one of two acquired by Canterbury Museum in the late 19th century. A donation of $£ 50$ to Canterbury Museum in 1889 came with the stipulation that it was to be used to secure two mummies along with other items which the director, Sir Julius von Haast, was to source while he was in London as the New Zealand Commissioner at the Colonial and Indian Exhibition (Fyfe 2006). Von Haast wrote to Giglioli, the director of the Zoological Museum of Vertebrates in Florence, who in turn contacted Ernesto Schiaparelli, Director of the Egyptian Museum in Florence, who finally contacted Émile Brugsch, the Assistant Director of the Egyptian Antiquities Service. Once this correspondence (which reads like a who's-who of museum directors in the late 19 th century) had run its course, von Haast was informed that, for $£ 5$, there was a "good plain mummy" from Akhmim that would be sent to Canterbury Museum. The second mummy was sourced through contacts in London as Brugsch could not supply a "fine mummy" until the following year. Payment was sent to Brugsch with shipping arrangements. Von Haast, unfortunately, would not see his acquisitions as he died in 1887, and the female mummy arrived in Christchurch in June 1888 (Fyfe 2006).

After acquisition from Canterbury Museum, the female adult mummy was put on display in Auckland Museum, moving through various spaces, until she was removed for a lengthy four year conservation treatment in the early 2000s. A CT scan was obtained in 2005 indicated she was about 32 years old, with teeth worn from a diet containing abrasive material (Dennison 2010). She was apparently ill from multiple conditions including a non-Hodgkin's lymphoma of a pretracheal lymph node, inflamed sinuses, and dental abscesses. The CT scan also determined that the internal organs had not been removed during mummification. There were also no amulets evident within the linen wrappings. The name Ta-Sedgement has been attributed to the mummy but is not confirmed.

The mummy likely comes from the excavations supervised by Gaston Maspero, then the Director of the Bulaq Museum and Antiquities Service, at Akhmim between 1884 and 1887 (Edwards 1884; Bierbrier 2012: 360; M. Claude, University Paul-Valéry Montpellier, pers. comm. 14 May 2014). This attribution is further supported by the fact that Brugsch was curator at the Bulaq and Cairo Museums under Maspero, with mummies being sold through the latter at this time (Brierbrier 2012: 83). Radiocarbon dating of the linen indicated the mummy lived within the mid-late Third Intermediate Period to early Late Period. The date range is $850-575 \mathrm{BC}$. Translation of hieroglyphics from the interior of the coffin is underway and will be reported on at a later date. The name "Souser" is present: only one other known example of the name is formed in the same way, Souser-dedes (known from a coffin once in a private collection in Brussels, and from mummy linen in the British Museum BM17177), and it may be a local name specific to the Akhmim region (M. Claude pers. comm.).

The collection has two examples of Fayum mummy portraits, one of a woman and the other of a man (Fig. 6). Fayum mummy portraits were likenesses painted on board and commissioned by the elite to adorn their mummy after death (Borg 2010). The paintings are likely from the site of er-Rubayat in the Fayum, which was found by Bedouin salt miners working in the area (Graf 1893; Thompson 1982: 4; Bierbrier 2000). The portraits were originally acquired from a dealer in Cairo by Herr Theodor Graf, a Viennese art trader, in 1887, who subsequently put them on display in Vienna (Auckland Star, 2 November 1935). Some portraits were sold off, but at least 200 were kept in the collection until the early 1930's when they were sold at auction (Thompson 1982:4). Hoffman, an Austrian merchant, acquired the two paintings from this auction and deposited them in Auckland Museum in 1935 soon after his arrival in Auckland. His intention was to have them displayed to encourage a buyer to come forward, but this was unsuccessful and the same arrangement was made with the Dominion Museum where they were transferred in May 1939 (letter, Oliver 1939). Hoffman made it clear to 

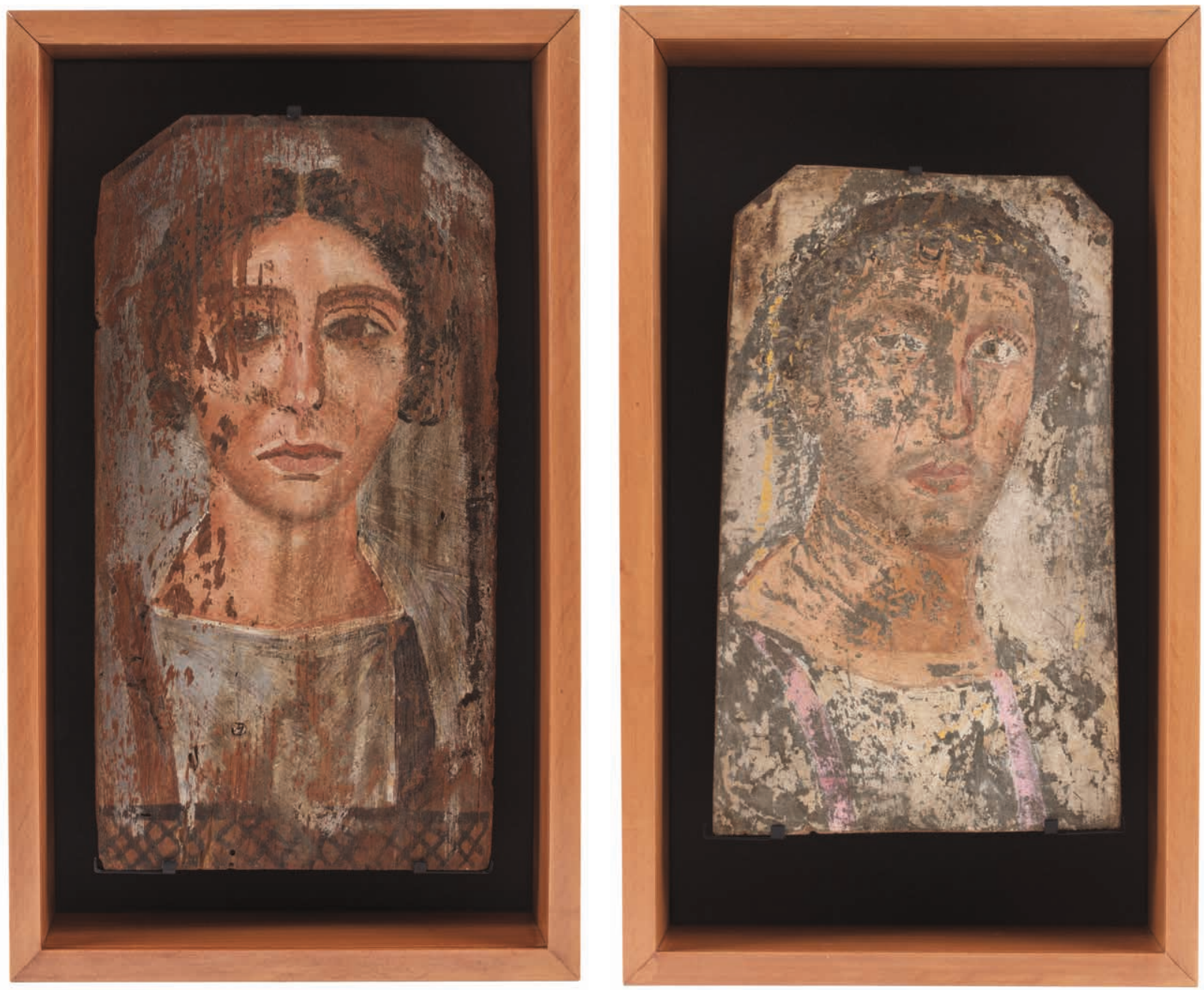

Figure 6. The Fayum mummy portraits: 22218 (left), 22219 (right). 1935.314. Auckland War Memorial Museum.

Oliver, that he would sell them for cash or exchange for a farm (letter, Hoffman 1939a) and the museum would receive a commission (letter, Hoffman 1939b). They were insured for three months by the Dominion Museum, then removed from display and returned to Auckland in late November of the same year (letter, Archey 1939), still under the original deposit arrangement. In a letter to Oliver (14 June 1940) Hoffman expressed his regret that no one could be found to purchase the portraits and donate them to a museum as he (Hoffman) intended to donate the money he received to "Returned Soldiers Organisation of NZ in favour of whose "Widows and Orphants-Fund [sic]".

Fayum mummy portraits are found in many Egyptology collections in the world, however, due to the lack of specific provenance information for many of them, including those acquired by Graf, until recently little was known about their purpose and manufacture (Borg 2010).

\section{Egypt at the Auckland War Memorial Museum}

The range of the material in the collection is remarkable for a museum on the other side of the world, and whose collecting activity was primarily through soliciting artefacts. The material from Cairo Museum and the EES puts the collection on par with many British and American collections. Cheeseman and subsequently Archey in the early 20th century acquired material from Egypt in the way that many institutions did, however it was also the personal contact with the likes of Brunton and Caton-Thompson that meant Auckland received more and higher-quality material than it otherwise may have. This is in spite of the attitude of some of the subscription services towards non-English institutions, as highlighted in a letter from the EES regarding the distribution of el Amarna pots restored by W.H. Young at the Ashmolean Museum:

"I think these are the special ones for England and I want these sent off first so that there should be no 
mistake. With the foreign ones it is less important which pot goes to which museum." (Records of Excavation: DIST.46.35a-c).

Approximately $72 \%$ of the Egyptian Collection at Auckland War Memorial Museum was obtained through subscription services, bulk purchases as described above, or large donations such as those by Waite, leaving approximately 550 artefacts donated to or purchased by the Museum over time. While some of these consist of purchases and exchanges, such as that for the female mummy, the majority were donations by New Zealanders who had obtained objects on their military tours, travels, or through purchases in Europe. The material that was acquired from the Cairo Museum, EES, and other sources represents the contribution of New Zealand to excavations in Egypt, at a time when large scale, effectively "crowd-funded" excavations, were occurring in the country. The connections that were made by the museum directors or through the likes of Waite tie the collection to the history of archaeology in Egypt, and in return the collections serve as a reminder of New Zealand's history in Egypt.

The original reason for the active solicitation and acquisition of the Egyptian collection has largely passed from public memory. However, the desire to educate and to present different cultures to the public, particularly school children, remained strong. Immediately post-WWII the Education Service was actively promoting school visitations to the museum, and to satisfy the needs of provincial children, who could not visit the museum, school cases were constructed for loan to schools and were mobile displays. One of these wooden boxes, with doors, and glass-fronted display incorporating objects, was on Ancient Egypt and its creation is reported in the Annual Report for 1945-46: 18. A later version is shown in Fig. 7. Egyptian objects featured prominently in gallery spaces from 1918 when the material from Cairo Museum was exhibited, and the larger space in the new building allowed more objects to be shown as they were acquired. Egyptian material featured in The Hall of General Anthropology in 1929, in the Logan Campbell ceramic gallery in 1968, the Hall of Man in 1969 (renamed People of the World in early 1980s), Ancient Civilisations in 1999-2007, and a large part of the space in the current Ancient Worlds Gallery which opened in 2007 is devoted to Egyptian material.

There is renewed interest amongst researchers in the older excavations in Egypt. In part this is due to the difficulties of working in Egypt after the "Arab Spring". Museum collections world-wide have become a substitute for excavations, allowing objects to be analysed and interpreted in new ways as more data is gathered and analytical methods have improved. The research being done in the archives of EES to track the destination of objects is complemented by work such as this, and Collections On-line, making the objects accessible to researchers elsewhere.

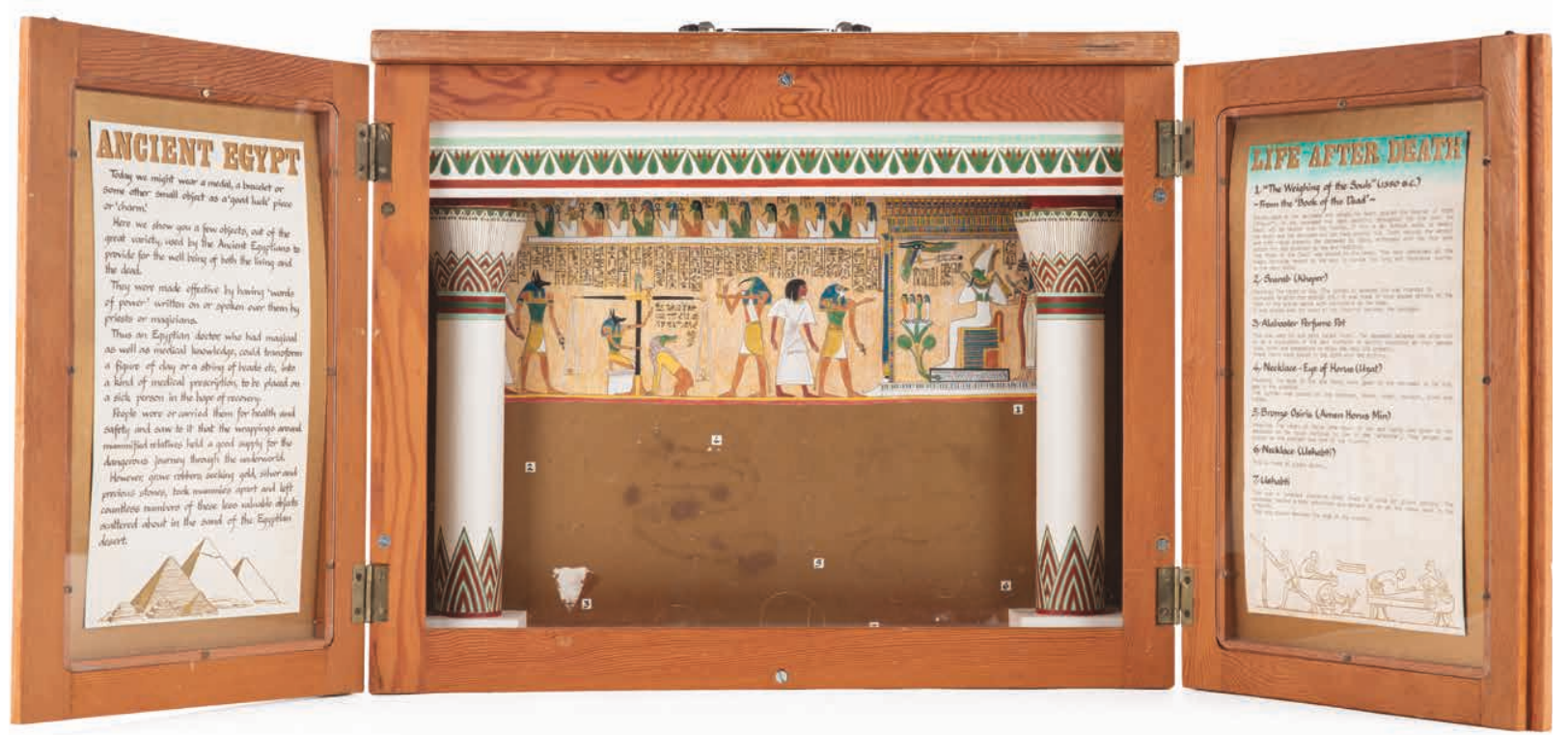

Figure 7. School case titled 'Ancient Egypt'. Objects removed before being decommissioned. 


\section{ACKNOWLEDGEMENTS}

This article comes from recent work undertaken by the authors to re-examine the Egyptian material in the Auckland War Memorial collection. Thanks to Martin Collett and Elizabeth Lorimer for retrieving correspondence from the museum archives, and to Moira White, Curator Otago Museum, for information about the 1946 acquisition. The image of alabaster vessels from Mastaba 2407 at Saqqara (Fig. 2) is courtesy of Patrizia Piacentini and Christian Orsenigo, and copyright of Università degli Studi di Milano, Egyptological Library and Archives, Quibell Collection. Thanks to Elizabeth Cotton for allowing imaging of the decommissioned school case. Thanks also to Rebecca Phillipps for commenting on a draft of this manuscript, and to two anonymous reviewers for the helpful comments.

\section{REFERENCES}

Published

Annual Report of the Auckland Institute and Museum for 1896-1897. Auckland War Memorial Museum Archives.

Annual Report of the Auckland Institute and Museum for 1916-1917. Auckland War Memorial Museum Archives.

Annual Report of the Auckland Institute and Museum for 1917-1918. Auckland War Memorial Museum Archives.

Annual Report of the Auckland Institute and Museum for 1945-1946. Auckland War Memorial Museum Archives.

Annual Report of the Auckland Institute and Museum for 1970-1971. Auckland War Memorial Museum Archives.

Aston, B.G., 1994. Ancient Egyptian Stone Vessels: Materials and Forms. Heidelberg: Heidelberger Orientverlag.

Bierbrier, M.L., 2000. The discovery of the mummy portraits. Pp 32-33. In Ancient Faces: Mummy Portraits from Roman Egypt, edited by S. Walker. New York: The Metropolitan Museum of Art.

Bierbrier, M.L. (ed.), 2012. Who Was Who in Egyptology. 4th Revised Edition. London: Egypt Exploration Society.

Bol, K.A., 2006. Every Museum Needs a Mummy: a study of the collecting practices that formed the ancient Egyptian collection at the Auckland War Memorial Museum. Unpublished MA dissertation, University of Auckland.

Borg, B.E., 2010. Painted Funerary Portraits. UCLA Encyclopedia of Egyptology, 1(1). Retrieved from https://escholarship.org/uc/item/7426178c.

Brunton, G., 1948. Matmar: The British Museum Expedition to Middle Egypt 1929-1931. London: Quaritch.

Caton-Thompson, G., 1952. Kharga Oasis in Prehistory. University of London: The Athlone Press.
Caton-Thompson, G., 1983. Mixed Memoirs. Gateshead: Paradigm Press.

Clark, J.D., 1952. Egyptian Predynastic Pottery. Otago Museum Handbook, No. I. 1950. 16 pp. text, map and 20 plates. Review. Antiquity 26(103): 168. doi: 10.1017/S0003598X00023991

Dennison, J., 2010. Ta-Sedgemet, the mummy in the Auckland War Memorial Museum. Records of the Auckland Museum 47: 111-127.

Distribution of el Amarna pots restored by Mr Young at the Ashmolean Museum. Records of Excavation DIST.46.35a-c. http://egyptartefacts.griffith.ox.ac.uk/ documents/dist-46-35a

Edwards, A., 1884. Maspero in Upper Egypt. The Academy 625: 301-302.

Egypt Exploration Society. “AC.TC.25-26.1636”. 29 November 2016. Online image. Flikr. Accessed 8 August 2018. https://www.flickr.com/photos/ egyptexplorationsociety/31153182732/in/album$72157677082159666 /$

Emmitt, J. and J. Hellum, 2015. A Predynastic vessel with a potmark in the Auckland War Memorial Museum. Records of the Auckland Museum 50: 15-19.

Fiechter, J.-J., 2009. Egyptian fakes: masterpieces that duped the art world and the experts who uncovered them. Paris: Flammarion.

Frankfort, H., 1927. Preliminary Report on the Excavations at Tell el-'Amarnah, 1926-7. The Journal of Egyptian Archaeology 13(3/4): 209-218. doi: $10.2307 / 3853960$

Frankfort, H. and J.D.S. Pendlebury, 1933. The City of Akhenaten: Part II: The North Suburb and the Desert Altars. London: Egypt Exploration Society.

Fyfe, R., 2006. The provenance of the Canterbury Museum mummies. Records of the Canterbury Museum 20: 15-19.

Gill, B.J., 2010. The Cheeseman-Giglioli correspondence, and museum exchanges between Auckland and Florence, 1877-1904. Archives of Natural History 37 (1): 131-149. doi: 10.3366/E0260954109001697

Graf, T., 1893. Catalogue of the Theodor Graf collection of unique ancient Greek portraits: 2000 years old, recently discovered and now on view in Old Vienna, Midway Plaisance at the World's Columbian Exposition, Chicago. Chicago.

Green, D., 1996. Mackesy, Charles Ernest Randolph. Dictionary of New Zealand Biography. Te Ara - the Encyclopedia of New Zealand. https://teara.govt. nz/en/biographies/3m19/mackesy-charles-ernestrandolph (accessed 13 July 2018).

Green, D., 1998. Waite, Fred. In Te Ara - the Encyclopedia of New Zealand, https://teara.govt.nz/en/ biographies/4w1/waite-fred (accessed 9 July 2018).

Hamilton, J., 2015. Sir John Logan Campbell in Egypt. Auckland War Memorial Museum - Tamaki Paenga Hira. First published 20 May 2015. Updated 29 June 2015. URL: www.aucklandmuseum.com/discover/ collections/topics/sir-john-logan-campbell-in-egypt

Hedley, A. and M. Hutching, 2009. Fernleaf Cairo: New Zealanders at Maadi camp. Auckland: HarperCollins. 
Lochhead, I.J., 'Gummer, William Henry' Dictionary of NZ Biography, first published in 1998. Te Ara - the Encyclopedia of New Zealand, https://teara.govt.nz/ en/biographies/4g24/gummer-william-henry (accessed 12 July 2018)

Moshenska, G., 2017. Esoteric Egyptology, Seed Science and the Myth of Mummy Wheat. Open Library of Humanities 3 (1): 1. doi: 10.16995/olh.83.

Museums to which were sent casts of the head of the princess, Daughter of Akhenaten, the original having been found at Tell-el-Amarna 1926-1927. Records of Excavation DIST.51.21. http://egyptartefacts.griffith. ox.ac.uk/documents/dist-51-21.

Orsenigo, C., 2017. James E. Quibell's records on Saqqara in the archives of Alexandre Varille. Pp. 675-683. In Bárta, M., Coppens, F., and Krejčí (eds), Abusir and Saqqara in the year 2015. Prague: Faculty of Arts, Charles University.

Pendlebury, J.D.S., 1933. The City of Akhenaten: Part III. The Central City and the Official Quarters. London: Egypt Exploration Society.

Piacentini, P., 2011. The dawn of museums and photography in Egypt. In Piacentini, P. (ed.) Egypt and the Pharaohs. From Conservation to Enjoyment. Milan: Skira.

Quibell, J.E., 1923. Excavations at Saqqara 1912-1914: Archaic Mastabas. Cairo: Institut Français d'Archéologie Orientale.

Reeves, M., and R.H. Wilkinson, 1996. The Complete Valley of the Kings. New York: Thames \& Hudson.

Stevenson, A., 2009. Palettes. UCLA Encyclopedia of Egyptology, 1(1). Retrieved from https://escholarship. org/uc/item/7dh0x $2 \mathrm{n} 0$

Stevenson, A., 2014. Artefacts of excavation. The British collection and distribution of Egyptian finds to museums, 1880-1915. Journal of the History of Collections 26 (1): 89-102. doi: 10.1093/jhc/fht017.

Stevenson, A. and D. Challis, 2015. Introduction: a modest little museum. Pp. 11-23. In Stevenson, A. (ed.), The Petrie Museum of Egyptian Archaeology: Characters and collections. London: UCL Press.

Stevenson, A., E. Libonati, and A. Williams, 2016. 'A selection of minor antiquities': a multisited view on collections from excavations in Egypt. World Archaeology 48 (2): 282-295. doi: 10.1080/00438243.2016.1165627.

Thompson, D.L., 1982. Mummy Portraits in the J. Paul Getty Museum. Malibu: J. Paul Getty Museum.

Waite, F., 1950. Egyptian Predynastic Pottery. Dunedin: Otago Museum.

\section{Newspaper}

An Egyptian Collection Inaugurated. 29 January 1918. Auckland Star, XLIX(25): 6. Retrieved from https://paperspast.natlib.govt.nz/newspapers/ AS19180129.2.60

Egyptian Relics. 30 January 1918. New Zealand Herald, LV(16761): 6. Retrieved from https://paperspast. natlib.govt.nz/newspapers/NZH19180130.2.51
Museum treasures - Colonel Waite's Gifts - Selection for Auckland. Otago Daily Times, 31 July 1946.

Not so much mystery now about the mummy. New Zealand Herald, 12 January 1971.

2000 Years Old. Mummy Portraits. Rare Museum Accessions. Auckland Star, 2 November 1935.

Letters and unpublished sources

Anon., 1925-26. Letter to the Distribution Committee, Egypt Exploration Society. Auckland War Memorial Archives.

Archey, G.E., 1935. Letter to M.C. Jonas, 7 May 1935, DIST.58.35a-b, Records of Excavation.

Archey, G.E., 1939. Letter to R. Hoffman, 1 December 1939. Auckland War Memorial Museum Archives.

Bowie, C.F.D., 1952. 'Untitled note.' The Life and letters of Fred Waite (unpublished draft). Complied by H.D. Massey and O.N.Gillespie. Alexander Turnbull Library 78-165-2/04.

British Museum, 1932. Letter to G.E. Archey, 30 June 1932. Auckland War Memorial Museum Archives.

Brunton, G., 1932a. Letter to G.E. Archey, 21 November 1932. Auckland War Memorial Museum Archives.

Brunton, G., 1932b. Letter to G.E. Archey, 12 August 1932. Auckland War Memorial Museum Archives.

Caton-Thompson, G., 1932a. Letter to G.E. Archey, 26 March 1932. Auckland War Memorial Museum Archives.

Caton-Thompson, G., 1932b. Letter to G.E. Archey, 5 July 1932. Auckland War Memorial Museum Archives.

Caton-Thompson, G., 1932c. Letter to G.E. Archey, 3 December 1932. Auckland War Memorial Museum Archives

Caton-Thompson, G., 1936. Letter to G.E. Archey, 1 January 1936. Auckland War Memorial Museum Archives.

Cheeseman, T.F., 1877. Letter to E.H. Giglioli, 19 September 1877. Auckland War Memorial Museum Archives.

Cheeseman, T.F., 1895. Letter to E.H. Giglioli, 17 June 1895. Auckland War Memorial Museum Archives.

Cheeseman, T.F., 1896. Letter to E.H. Giglioli, 12 October 1896. Auckland War Memorial Museum Archives.

Cheeseman, T.F., 1904. Letter to Director of Excavations, Beni Hasan, 5 April 1904. Auckland War Memorial Museum Archives.

Cheeseman, T.F., 1916. Letter to J.E. Quibell, 15 June 1916, Auckland War Memorial Museum Archives.

Cheeseman, T.F., 1918. Letter to J.E. Quibell, 15 March 1918, Auckland War Memorial Museum Archives.

Collins, K.R. 1952. 'Untitled note'. The Life and letters of Fred Waite (unpublished draft). Complied by H.D. Massey and O.N.Gillespie. Alexander Turnbull Library 78-165-2/04

Egypt Exploration Society, n.d. List of Antiquities presented to the Auckland Institute, New Zealand. DIST.REG.03. Auckland War Memorial Archives.

Giglioli, E.H., 1877. Letter to T.F. Cheeseman, 23 November 1877. Auckland War Memorial Museum Archives. 
Hoffman, R., 1939a. Letter to W. Oliver, 7 June 1939. Original in archives of Te Papa Tongarewa, reproduced in Egyptian Collection Document Bank, compiled by Ross O'Rorke 1998.

Hoffman, R., 1939b. Letter to Secretary National Art Gallery and Dominion Museum Board of Trustees, 12 July 1939. Original in archives of Te Papa Tongarewa, reproduced in Egyptian Collection Document Bank, compiled by Ross O'Rorke 1998.

Hoffman, R., 1940. Letter to W. Oliver, 14 June 1940. Original in archives of Te Papa Tongarewa, reproduced in Egyptian Collection Document Bank, compiled by Ross O'Rorke 1998.

Jonas, M.C., 1927. Letter to G.E. Archey, 8 January 1927. Auckland War Memorial Museum Archives.

Jonas, M.C., 1928. Letter to G.E. Archey, 21 April 1928. Auckland War Memorial Museum Archives.

McCormick, E.H., 1942. Letter to G.E. Archey, 23 April 1942. Auckland War Memorial Museum Archives.

Oliver, W., 1939. Letter to G.E. Archey, 26 May 1939. Original in archives of Te Papa Tongarewa, reproduced in Egyptian Collection Document Bank, compiled by Ross O’Rorke 1998.
Oliver, W., 1943. Letter to H.D. Skinner, 24 August 1943. Original in archives of Te Papa Tongarewa, reproduced in Egyptian Document Bank, compiled by Ross O'Rorke 1998.

Quibell, J.E., 1916. Letter to T.F. Cheeseman, 31 January 1916. Auckland War Memorial Museum Archives.

Skinner, H.D., 1946. Letter to G.E. Archey, 26 September 1946. Auckland War Memorial Museum Archives.

Skinner, H.D., 1952. "Untitled note". The Life and letters of Fred Waite (unpublished draft). Complied by H.D. Massey and O.N. Gillespie. Alexander Turnbull Library 78-165-2/04

Waite, F., 1942. Egyptian Prehistoric Material. Auckland War Memorial Museum Archives.

Waite, F., n.d. ““'Typical!” Note accompanying "Forged Egyptian Antiquities"” - by T.G. Wakeling, published in London, 1912." The Life and letters of Fred Waite (unpublished draft). Complied by H.D. Massey and O.N. Gillespie. Alexander Turnbull Library 78-165-2/04.

Joshua Emmitt, School of Social Sciences, Faculty of Arts, University of Auckland. josh.emmitt@auckland.ac.nz Louise Furey, Auckland War Memorial Museum, Auckland. 



\title{
Preserving a legacy: an analysis of the role and function of the Mackelvie Trust Board, 1885-2010
}

\author{
Andrew McKay University of Auckland
}

\begin{abstract}
Established to manage the art collections of one of Auckland city's former businessmen, the Mackelvie Trust Board has operated for over 125 years. The Trust was set up to administer James Tannock Mackelvie's (1824-85) collection of European paintings, books, decorative arts and objets de vertu including bronzes, clocks, coins and natural treasures now held at the Auckland Art Gallery, the Auckland War Memorial Museum and the Auckland Public Library. This article will explain how part of the collection came to be at the Auckland War Memorial Museum, how the Trustees administered the will, and how the Trust Board itself evolved to include professional expertise. The impact of this evolution on Mackelvie's gifts and bequest and the collection's development is one of the most important findings. After an evaluation of the collection's management over time, it is concluded that while the Mackelvie Trust Board has always endeavoured to implement Mackelvie's wishes, financial and physical restrictions led to certain compromises regarding control and display of the collection. Nevertheless, the Trustees have always acted in good faith and protected Mackelvie's legacy for the enjoyment of future generations of Aucklanders and visitors to the city.
\end{abstract}

\section{Keywords}

Mackelvie Trust Board; Auckland Institute and Museum; James Tannock Mackelvie.

\section{INTRODUCTION}

The subject of this study, James Tannock Mackelvie (born Glasgow, Scotland, 1824 - died London, England, 1885) was a man known to enjoy the good things in life (Fig. 1). To a friend, Mackelvie wrote "all I ever wanted was $£ 5,000$ a year, and nothing to do but spend it" (Carroll 1994). Art was his passion, and the people of Auckland have become the main beneficiaries of his ability to indulge this interest. During Mackelvie's six short years in Auckland (1865-1871) he acquired a substantial fortune (estimated at $£ 60,000$ ). With a strong sense of civic duty, Mackelvie was a founder of the Acclimatisation Society, which formed the botanical garden in the Domain, and was an inaugural member of the Auckland branch of the Philosophical Society in 1867 . This organisation changed its name the following year to become the Auckland Institute and Museum (Stacpoole 1985).

On his return to London, England in 1871, he purchased a substantial inner-city residence near Victoria Station, London. As the centre of the art world, it was the ideal base for a gentleman collector of means, and over the next fourteen years Mackelvie undertook his own 'Grand Tour', and built an extraordinarily diverse collection of "paintings, sculptures, bronzes, ivories, jades, enamels, porcelain, clocks and watches, coins and medals, arms and armour, books, mosaics, bonbonnieres, rock crystal and glass" that he intended be used to form a teaching collection in Auckland (Stacpoole 1985: 7). He also built up a fine collection of books, along with archaeological and ethnographic artefacts that were gifted to the Auckland Institute and Museum prior to his death. ${ }^{1}$ This latter collection comprised prehistoric materials found in settlements along the shores of Swiss lakes such as stone adzes, pottery, knives and spindles gifted in 1883 in order that the Auckland Institute and Museum have truly encyclopaedic collections (Stead 2001). All of the artefacts, artworks and publications that Mackelvie amassed are now owned by, or entrusted to, Auckland's three key cultural institutions - the Auckland Art Gallery, the Auckland War Memorial Museum² and the Auckland

1 Mackelvie bequeathed some 500 books, which included volumes with superb lithographs, and a book of specimens of tapa cloth brought back from Captain Cook's third Pacific voyage. More than half of the book collection focussed on the early history of the colony, and was sent to the curator and secretary of the Auckland Institute and Museum, Thomas Frederic Cheeseman, between 1877 and 1884.

2 In 1997 Auckland Institute and Museum changed its name to Auckland War Memorial Museum to reflect the changed legislation-mandated governance structure. The majority of references in this paper refer to Auckland Institute and Museum, or Auckland War Memorial Museum, but for simplicity the name Auckland Museum is used throughout. 


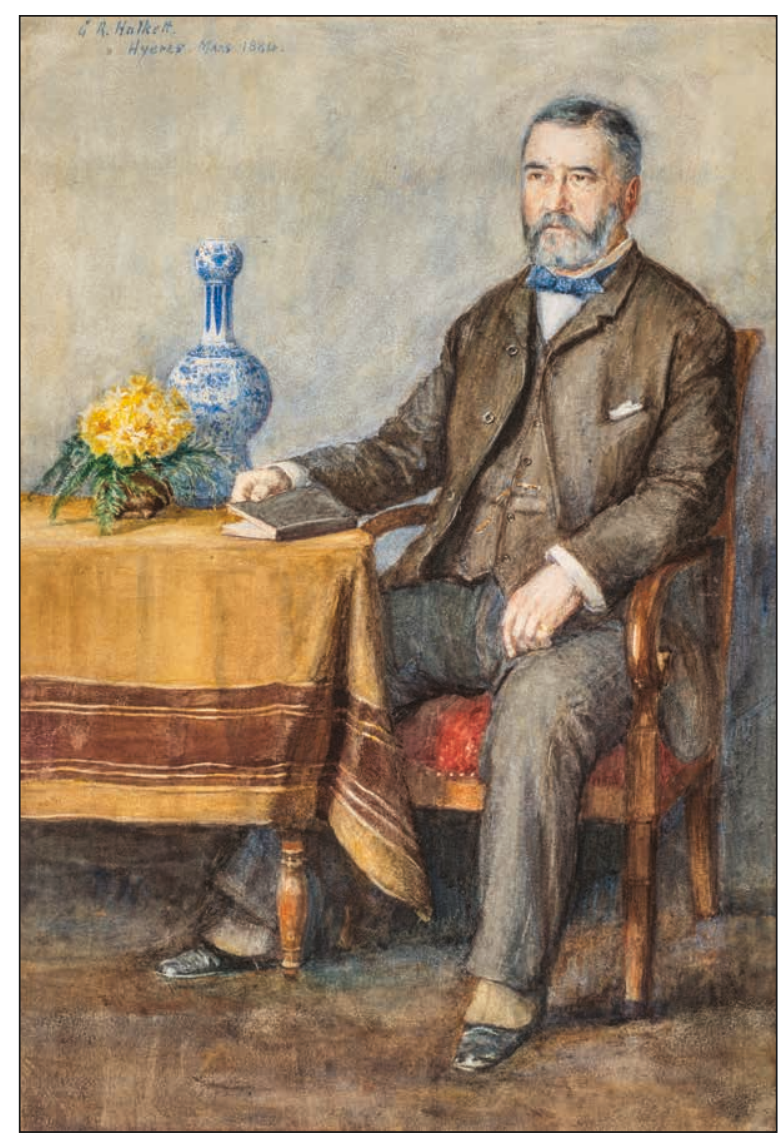

Figure 1. George Halkett, James Tannock Mackelvie, 1884, watercolour Mackelvie Trust Collection, Auckland Art Gallery Toi o Tāmaki, bequest of James Tannock Mackelvie, 1885. M1885/1/32

Public Library. Mackelvie was a methodical man and kept meticulous diaries, letter-books and inventories of his collection. Fortuitously for the future Trustees of his collection, he would prepare and publish, just prior to his death, the Catalogue of the Mackelvie Collection for Auckland, New Zealand, 1885. Wanting his legacy to be maintained, Mackelvie also commissioned oil, watercolour and photographic portraits of himself, and prepared a will that stipulated that his collection would be placed in Trust and administered by an independent committee tasked with the responsibility of adhering to the terms of his will after his death.

\section{ADMINISTERING THE WILL}

Back in London in 1877 Mackelvie had his lawyer draft his will shortly after he had made his first gift of Jardine's Naturalist's Library to the Auckland Public Library. Even though he was a single man with no immediate family, he kept the terms of the will confidential to ensure that no one would pressure him to change his vision for the civic repositories of Auckland being the recipients of his collection (Will 1877). After his death eight years later in June 1885, Mackelvie's will provided small legacies for his sister, nieces and nephews, but left the bulk of his assets to a trust to be set up in his name - The Mackelvie Trust. The will specified that four Auckland-based Trustees - the banker David Limond Murdoch (1885-1911), artist Albin Martin (1885-1888), businessman and philanthropist John Logan Campbell (1885-1912) and lawyer-financier Thomas Russell (1885) - be appointed as executors of the Trust and "shall stand possessed the said pictures, prints, bronzes, statues, vases, works of art, articles of vertu and curiosities... bequeathed to them" (Will 1877: 10).

Mackelvie's will (1877) also specified that any residue monies from the estate be used to "purchase or acquire a site in or near the city of Auckland in New Zealand suitable for the erection of a building... and cause to be erected on such site a museum capable to receive and display the said collection" (Will 1877: 11). Mackelvie favoured a site in the expansive grounds of Government House in Waterloo Quadrant, near to the Auckland Museum in Princes Street (Fig. 2). Three years before his death, Mackelvie wrote a letter to Thomas Cheeseman outlining this proposal:

"My idea has always been that as Auckland is no longer the seat of Government, Government House does not require so much vacant ground around it, and that a part of it should be used for the erection of an Art Gallery for the benefit of the inhabitants. I quite agree with Sir George Grey's idea of erecting a large building by degrees on that ground, and I hope it is not too late to abort it. I also agree with you as to the folly of a number of separate institutions all over the town, requiring no end of expenditure to look after them." (Mackelvie 1882)

While Cheeseman had been appraised of Mackelvie's wishes prior to his death, Mackelvie's stipulation that the collection had to be housed in a building specifically erected for the purpose both surprised and caused consternation to the Auckland City Councillors who received copies of his will. Mackelvie believed that housing his collection in its entirety in a purpose-built structure would preserve its integrity. This idea was at variance with what the City Council had previously been led to believe: that Mackelvie would bequeath his collection to the City Council unencumbered (Garrity 1975). It was this assurance, along with Sir George Grey's promise to donate his sizeable collection of books and manuscripts, which was the catalyst for the competition to design Auckland's first Free Public Library and Art Gallery in 1883. The French Châteaustyle building was designed by Melbourne architects John H. Grainger and Charles A. D'Ebro, and the foundation stone for the building was laid at the corner of Coburg (now Kitchener) and Wellesley Streets on 4 June 1885 (also coincidentally the date of Mackelvie's death in London). The Auckland Free Library and Art Gallery opened to the public on 17 February 1888 . To accommodate Mackelvie's collection, significant alterations were made to the design of the art gallery section of the building and a wing added to create The Mackelvie Gallery, specified to be attached to the Free Public Library and Art Gallery. It was not until the construction of a new central library building in 1971 that the Mackelvie and Grey book collections were separated and allocated to the Auckland Public Library. 


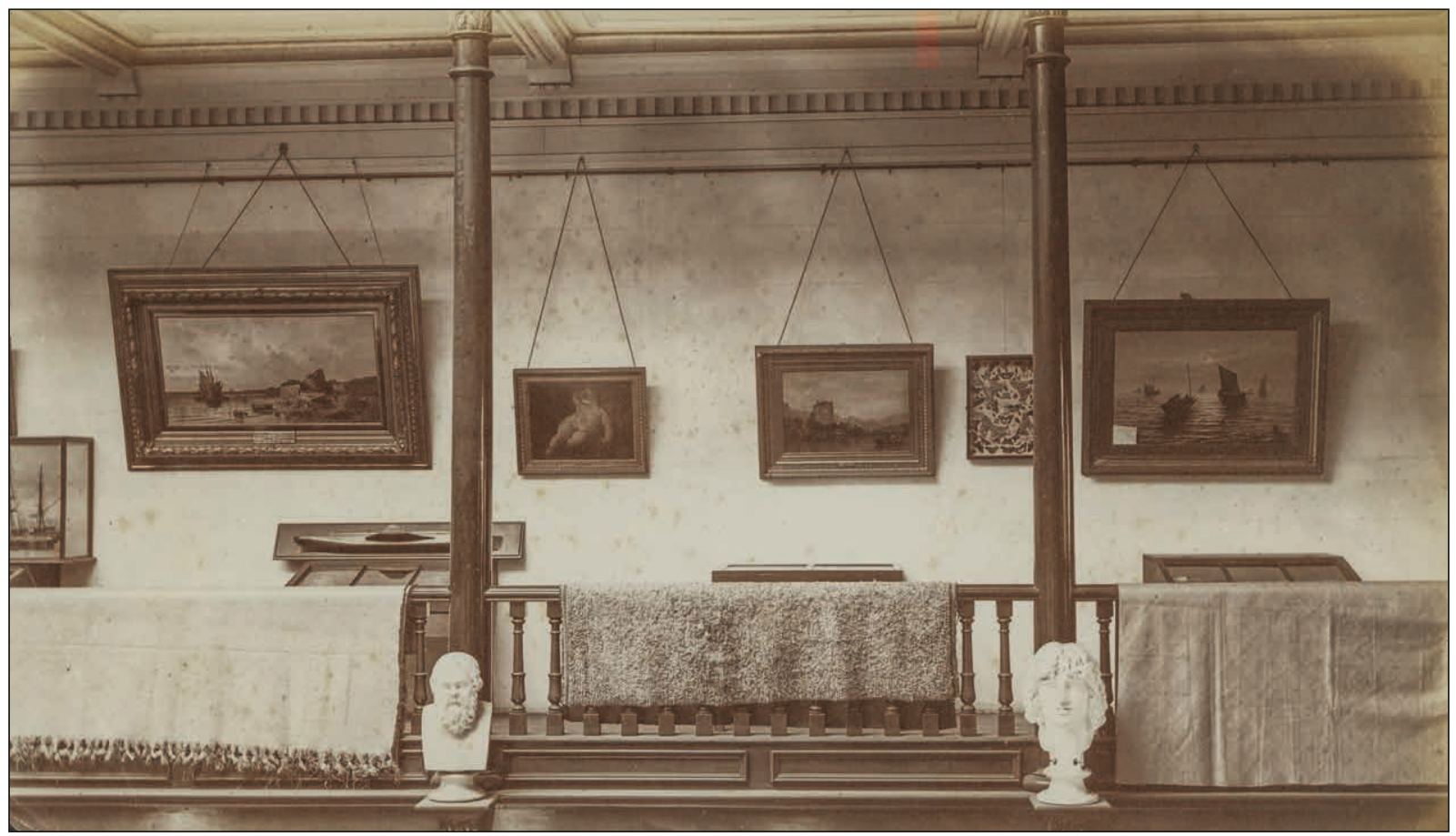

Figure 2. Mackelvie Collection, Auckland Museum, Princes Street, c. 1882. Print, Ph-NEG-SL780, Auckland War Memorial Museum.

Another condition of Mackelvie's will was that the public be granted free access to view his collection, including on Sundays. To support this, further sums of $£ 2,000$ and $£ 1,000$ were to be invested with the income derived providing salaries for custodians, and also pay for maintenance and insurance of the gallery. Any remaining surplus was to be allocated for the "purchase, transport and arrangement" of art or objects to add to the existing collection (Will 1877: 12). It would be this last provision, the requirement that the Trustees make acquisition decisions, which would prove most problematic.

Unfortunately a global economic downturn during the mid-1880s decreased the value of Mackelvie's property and shares, ending speculation about a dedicated gallery being constructed: the $£ 10,000$ allocated in the will for gallery construction costs had depreciated to about half its value. That would suffice only to purchase a site and erect a building, with no funds left to invest to pay staff, maintain or build on the collection (Vennell 1971). This meant that the Trustees were left in the position of having the authority, but not the means to administer the terms of the Trust. For the next eight years, the problem of how to resolve this dilemma became their main focus. As a result, the majority of his bequested collection, which had arrived from England in 1887, was held in the bonded store of Brown and Campbell in Shortland Street, and was unable to be enjoyed by the public as Mackelvie had envisaged.

The High Court of Justice, Chancery Division, in London approved the 'scheme' to amend the relevant provisions of the will so that Mackelvie's collection could be housed in a wing attached to the new municipal art gallery. The favourable ruling required confirmation by the Supreme Court of New Zealand (which was duly given in 1892) that whilst still giving "practical effect to the intentions of the testator," the Trust was relieved of the costly burden of constructing its own dedicated Mackelvie building (Will 1877: 26). This momentous decision released the capital necessary to purchase art for the collection. The numerous boxes stored at Brown and Campbell's premises could be unpacked and the contents finally put on display in the new 'Mackelvie Gallery' in 1893.

The Mackelvie Gallery within the Free Public Library and Art Gallery was not large and a lack of wall space to display artwork soon became a major issue. Following extensions in 1912 and 1916, the building was able to accommodate more artworks and decorative arts items. Acquisitions could consequently be made for both the City and Mackelvie collections. By 1922, further variations were made to Mackelvie's will that superseded the 1892 scheme. Roles were defined: the City Council would control the buildings while the Trustees maintained control of the collection. Alarmingly, a new clause was added to the will allowing the City Council the right to give "the Trust Board two years' written notice to remove the Mackelvie collection from the said buildings," if so desired (Mackelvie Trust Board Papers 1922: 3). This clause has never been invoked, however.

Still the conditions for display of the burgeoning Mackelvie collection remained cramped in the art gallery building, and in 1923 it was suggested that the Mackelvie Trust Board relocate the entire collection to the proposed Auckland War Memorial Museum which 
was to be built in the Domain. The Trust rejected this idea on the basis that an art gallery provided the proper viewing conditions for the largely pictorial collection (Vennell 1971). However, Dr Gilbert Archey, (later Sir) (1890-1974), Director of the Auckland Museum emphasised the desirability of having the decorative arts in one building as a single comprehensive display. In 1931 Archey offered a solution to the space issue when he approached the Mackelvie Trustees asking for all the pieces from the Mackelvie decorative arts collection for display in the newly-constructed museum which had opened in 1929. This offer was accepted on the proviso that the items be displayed in a dedicated space and be clearly labelled as on loan from the 'Mackelvie Trust' collection, and that they would be returned to join the rest of the collection at the Auckland Art Gallery on demand.

In 1955, the Auckland City Council proposed an internal agreement that would divide the Mackelvie artwork collection into groups to be exhibited in rotation, with the Auckland Art Gallery having the authority to include Mackelvie artworks in temporary exhibitions curated by its professional staff. In addition, the Board would be encouraged to exhibit portions of the collection throughout the Province of Auckland (Mackelvie Trust Board Papers 1955). In keeping with the terms of the will, the art displayed was required to be clearly labelled as belonging to the Mackelvie Trust collection, with conditions regarding free access to be observed (Agreement on Mackelvie Art Collection 1955). It was decided that a private bill be introduced into Parliament "to give effect to the new agreement" which would allow the Mackelvie Trust Board wider powers to utilise the collections held in the three cultural institutions in Auckland (Vennell 1971: 36). After much expensive consultation with lawyers, this bill was finally drawn up and introduced into the House of Representatives in August 1958. It became law the following month as the Mackelvie Trust Act 1958 and remains on the statute books today.

\section{AGENCY AND FUNCTION OF THE MACKELVIE TRUST BOARD}

A key focus of the Mackelvie Trust Board, particularly during the first half of the 20th century, was on improving the environmental conditions for the display of their collection in the Mackelvie Gallery. The Victorian-era Auckland Art Gallery lacked temperature and humidity control. The temperature variation, especially during the peak summer and winter periods, soon caused considerable damage to a number of the paintings. At a meeting of the Trustees in 1917 a temporary solution was found and artist (and inaugural director of the Elam School of Art) Edward Payton (1859-1944) was authorised to clean mildew off the paintings (Mackelvie Trust Board Papers 1917). However, such cosmetic treatment did not address the cause of the problem. In 1927, a heating system, paid for by the Auckland City Council, was finally installed. Unlike the painting collections, the decorative arts in the Mackelvie Collection were not affected by such poor environmental conditions. This included wooden furniture [display cases and vitrines] which benefitted from the modern storage conditions at the new museum building in the Domain to which it was relocated in 1931.

These changing circumstances for the collection often occasioned the production of a catalogue or inclusion of the Mackelvie Collection in an Auckland Museum or Auckland Art Gallery publication. The catalogue Mackelvie compiled just prior to his death in 1885 was subsequently amended and republished, particularly during the earlier years of the Trust, when new items were acquired or sold from the collection. The publication of catalogues served not only a practical purpose - to provide the most current inventory record of the collection - but also educated the public on the contents of the Mackelvie Collection itself. Publications on the collection helped improve its visibility as an entity. In The Centennial History of the Auckland Institute \& Museum 1867-1967 A.W.B. (Baden) Powell, assistant director of the Auckland War Memorial Museum from 1936 to 1963 , outlined the importance of the Mackelvie collection to the museum. Powell writes that the Mackelvie collection "has added pieces in every field, many of superb quality," in particular its assembly of watches and clocks, with an "emphasis on the history of clock-making rather than novelty," a range of European 18 th-century snuff boxes, an 18th-century lacquer chest and numerous Oriental ceramics (Powell 1967).

Further opportunities to publicise the collection included exhibitions in 1971 to mark the centenary of the city of Auckland. This included a display of Auckland landscape paintings in the Gallery along with the exhibition 'Auckland 1871' comprising objects of china, glass and silver in the Museum (Gamble 1971). A further exhibition followed in 1985, jointly curated by the Auckland Art Gallery curator Andrew Bogle and Auckland Museum's Curator of Applied Arts Brian Muir, to commemorate the centenary of Mackelvie's death. This exhibition was spread over both institutions, with displays at both the Auckland Art Gallery and the Auckland Museum (Fig. 3). During this time, a centennial display was also held in the Rare Books Room of the Auckland Public Library of select books from the Mackelvie book collection. This display reflected Mackelvie's great interest in the arts, and included fine examples of 19th century illustrated book production such as wood and copper engraving, etching, lithography and hand colouring (The Mackelvie Collection 1985). By this stage, the Mackelvie Collection had grown to approximately 2,500 items in the Art Gallery and 900 in the Museum with about 500 books in the Public Library (Mackelvie Trust Board Papers 1984). It was agreed that only the best of the Mackelvie Collection and works not often displayed were to be featured in the centenary exhibition with "the emphasis in each case... on the cream of the collections" (Mackelvie Trust Board Papers 1984). An event of this scale was testament to the individuals on the Board at the time who had the organisational ability, public relations skills and commercial savvy. These combined to ensure that the Centennial Exhibition became a pivotal moment in the history of the Trust. 


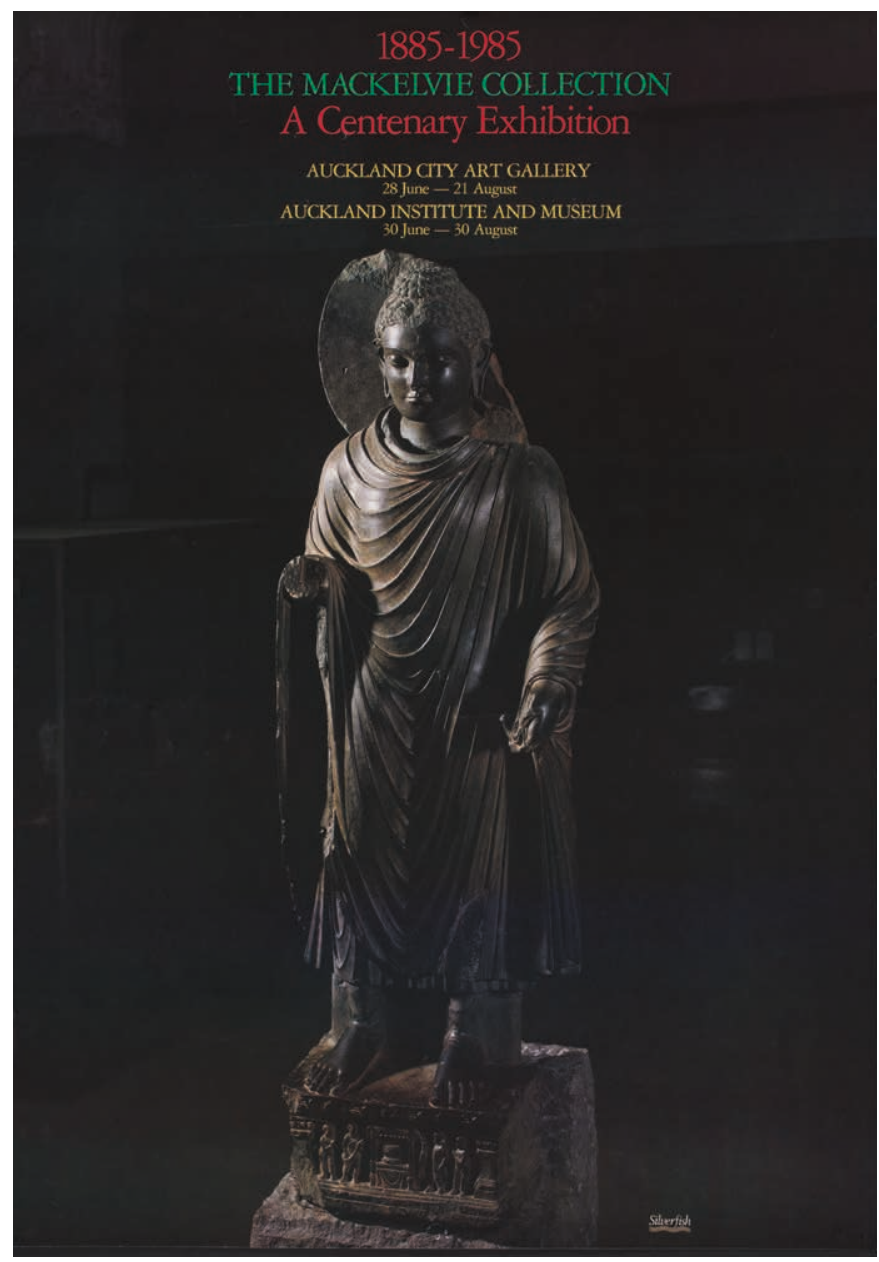

Figure 3. Poster from the Auckland War Memorial Museum. The Mackelvie Collection 1885-1985. A centenary exhibition. EPH-PT-6-61.

\section{COLLECTION MANAGEMENT}

Recognising that there was no expertise in art acquisition or curatorship amongst the initial complement of Trustees, the Mackelvie Trust Board, via connections in London, appointed a series of art buyers to assist with the purchase of pictures in London during the early twentieth century. These included the Scottish artist Sir George Reid (1841-1913), President of the Royal Scottish Academy, and the English-artist (and member of the Royal Academy) Marcus Stone (1840-1921). ${ }^{3}$ These men were selected based upon their reputation in art circles with the Trustees placing considerable faith in the ability of these men to purchase paintings representative of key developments in British art and therefore suitable for the educational purpose of the collection. Consequently there was little or no guidance as to what to buy but plenty of

3 In 1897 Mackelvie Trustee David Murdoch wrote to the English-artist Marcus Stone requesting his services as art agent for the Mackelvie Trust Board in London. Stone had recently married Laura Brown, the daughter of John Logan Campbell's business partner William Brown. money, derived from income received from the Trust's investments in property and debentures.

By the early 1920s, the Trustees, for no apparent reason, terminated the arrangement with their London agents, and instead decided themselves to make a series of purchases for the collection. This proved to be an unwise decision as many of these purchases during this period came to be assessed by later Trustees as poor choices which indicated that expert advice was necessary. Edward Payton (1859-1944), the former director of the Elam School of Fine Arts, who was concerned about the excessive quantity of Victorian paintings and the overall quality of the acquisitions made by the Trustees became an agent for the Board in 1930. He was sent to Europe with the authority to spend up to $£ 6000$ on paintings, focussing on "French, British, Cornish and Scottish works" (Stacpoole 1985: 11). However, Payton's purchases received a torrent of criticism when they were displayed in the gallery on his return. Irish playwright George Bernard Shaw (1856-1950) who visited the Auckland Art Gallery in 1934, exclaimed "Bonfires! What you need is some nice big Bonfires!" when asked his opinion of the Mackelvie collection (Fairburn 1947: 56). 
From 1885 until 1930 over $£ 16,000$ was spent by the Mackelvie Trust Board in acquiring English paintings for the collection, a huge amount of money to spend on art at that time. The combination of the Board's laissez faire approach to planning acquisitions and a lack of art knowledge among the Trustees themselves unfortunately resulted in a high number of poor quality works entering the collection.

In 1944 the situation took a turn for the better. The Chairman of the Mackelvie Trust Board Sir Cecil Leys (1877-1950), proposed that the English-born farmer, sculptor and President of the Auckland Society of Arts, Richard Oliver Gross (1882-1964) join the Trust (Mackelvie Trust Board Papers 1944). As a sculptor, Gross sought to address the lack of sculpture in the Mackelvie collection by acquiring a number of important bronze figurative sculptures including Aristide Maillol's The Woman who walks through the water in 1957 (Stacpoole 1985). The Board sought assistance with the purchase of the Maillol nude bronze from Gilbert Archey, Director of Auckland Museum, and with a donation from the National Art Collections Fund, they acquired it for $£ 2,700$ (Mackelvie Trust Board Papers 1957). In addition to Gross, Leys sought to extend the range of advisers to include John Rothenstein (1901-1992), the Director of the Tate Gallery in London, and the Australian newspaper executive and governor of the Art Gallery of South Australia in Adelaide, Sir Frederick Lloyd Dumas (1891-1973). Both men provided excellent advice on acquisitions.

\section{PROFESSIONAL STAFFING CHANGES}

Changes in staffing at the Auckland Art Gallery affected the direction in which the Mackelvie collection was developed during the immediate post-war period. In 1952, Dr Eric Westbrook (1915-2005), an English-born artist and curator was appointed as the first professionally trained director. The Trustees felt that the "greatest difficulties of maintaining the Board's collection would almost automatically disappear" (Mackelvie Trust Board Papers 1951). Westbrook was seen as someone who could take the Auckland Art Gallery and its collection, along with the Mackelvie art collection, to the next stage in its journey.

Westbrook ensured that it was his sole responsibility as Art Gallery Director to select the pictures to be exhibited, with the Mackelvie Trust Board reserving the right to select those for display only in the Mackelvie Gallery. This arrangement continued under Westbrook's successor, the art historian and academic Peter Tomory (1922-2008), who was instrumental in introducing professional standards to the Art Gallery during his directorship from 1956 until 1964 (Brown 1981). Tomory quickly set up a conservation laboratory at the Art Gallery to redress the neglect of the Art Gallery's collection, and Mackelvie Collection works were also treated by the conservator Les Lloyd. Considered to have a good first-hand knowledge of the London art market, Tomory immediately put in place a robust policy for the acquisition of art works that included the Mackelvie collection. He determined that the Mackelvie Collection could benefit from some judicious deaccessioning which would improve its coherence and also permit a greater rotation of the collection for display. If the works were sold on the open market, this would also release capital that could be put to use to acquire new works.

The controversial culling of the collection that resulted was not limited to items in the Mackelvie Gallery at the Auckland Art Gallery. Mr T.J. (Trevor) Bayliss, inaugural Curator of Applied Arts and later Assistant Director of Auckland Museum, wrote to the Mackelvie Trust Board on more than one occasion proposing that items which had "no real museum value" be disposed of (Mackelvie Trust Board Papers 1968). In 1975, for example, Bayliss suggested a review of the museum's Mackelvie collection objects, with the revenue from the sale of the collection items to fund the purchase of a pair of Tang Dynasty Urns (Mackelvie Trust Board Papers 1975). Although this purchase did not eventuate, it indicates that Bayliss (who was an expert in British and European ceramics, and writing a guide to the Museum's ceramic collection), recognised that there were many inferior pieces in the Mackelvie Collection. A detailed inventory was eventually compiled of all items in the Mackelvie Collection held by Auckland Museum and forwarded to the Mackelvie Trust Board. The inventory showed weaknesses in the museum's [Mackelvie] collection of silver (Mackelvie Trust Board Papers 1987). Trustee Dr Lindo Ferguson recommended that the Board investigate local silver purchases (of English or New Zealand objects), and solicit donations from any local silver collectors of the same. Subsequent additions to the Mackelvie silver collection included a pre-1899 Fabergé bell push made of gold, silver, enamel and ruby (1991) and an 1875 English silver ewer (1992).

In the $1970 \mathrm{~s}$ and $1980 \mathrm{~s}$ the Trustees were - in the opinion of John Stacpoole - pure amateurs, "a group of people who had a liking to art" (Stacpoole 2017). ${ }^{4}$ During these decades, the Mackelvie collection continued to focus on acquiring foreign paintings, while the acquisition of New Zealand works was the responsibility of the Auckland Art Gallery staff. This differentiation constrained the number of acquisitions made by the Board as it was a period where the price of international art work had escalated dramatically, making it difficult for them to acquire works. In order to generate funds to purchase new works, the Trustees continued to deaccession inferior collection items, discreetly auctioning off selected paintings and objects.

Most of the collection development was centred on the paintings in the Art Gallery, however the Trustees did occasionally buy decorative art pieces for Auckland Museum, to correct perhaps an historical imbalance across the collection. This occurred more frequently from the 1960s when Dr Gilbert Archey recommended that the Mackelvie Trust Board use the museum's agents in London to identify items of furniture for acquisition (Mackelvie Trust Board Papers 1960). ${ }^{5}$

4 John Massy Stacpoole OBE (1919-2018) was a Mackelvie Trust Board Trustee (1972-2008) and Chairman (1974-1990).

5 During this period these London-based agents included the fine arts dealers Thomas Agnew \& Sons and Roland, Browse \& Delbanco. 
Through such agents, they acquired a significant 18th-century lacquered chest-on-chest with decorative Chinese panel inserts, made by the firm of Elizabeth Bell in London, which was purchased for an undisclosed sum in 1963, and the sculptured Indian Gandharan figure of Buddha c. AD 200 (Fig. 4) was purchased for $\$ 6,000$ at a London auction in 1970. The Buddha and the chest-onchest were assigned to Auckland Museum by the Mackelvie Trust Board, forming a key part of the Asian art collection and the Landmarks: International Design and Decorative Arts collection, and became part of the permanent displays in the Asia Hall and Disney Hall of English Furniture (Gamble 1971). In 1984 Trustees Dr Lindo Ferguson and John Stacpoole purchased a 19th-century commode made by Anton Seuffert (1815-1887) at the Auckland auction house Cordy's for $\$ 6,750$ (Fig. 5) and this, too, went on display at Auckland Museum (Mackelvie Trust Board Papers 1984). These same two Trustees had previously purchased a pair of carved Māori panels from the house of Te Tiki a Tamamutu at Waitahanui, Taupo in 1981. The ethnologist and assistant director of the museum Dr David Simmons prepared an acquisition proposal for the panels, researching their provenance and history which was presented to the Mackelvie Trust Board in 1981. There was much discussion among the Trustees over the principle of owning Māori artefacts. It was suggested to the Trustees by Dr Simmons that "the pair of carvings would sell for $£ 40,000$ if they could be sold overseas and probably for $\$ 10,000$ if they were auctioned in New

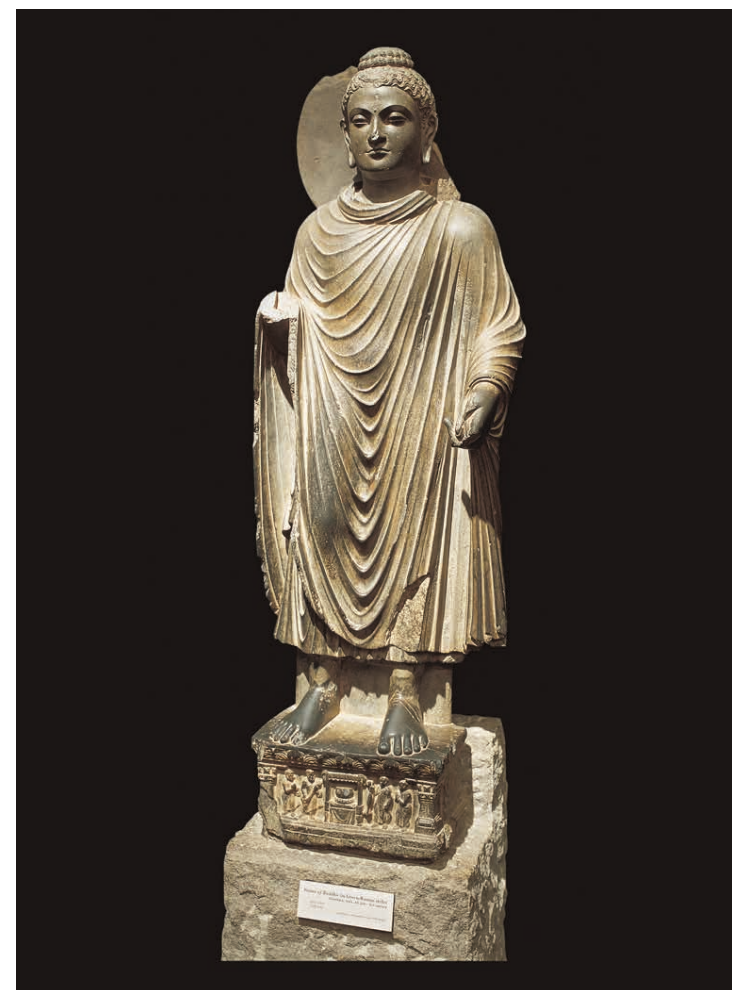

Figure 4. Buddha, AD 2nd-3rd century. Gandhara, North India. Mackelvie Collection, Auckland War Memorial Museum. M1067.

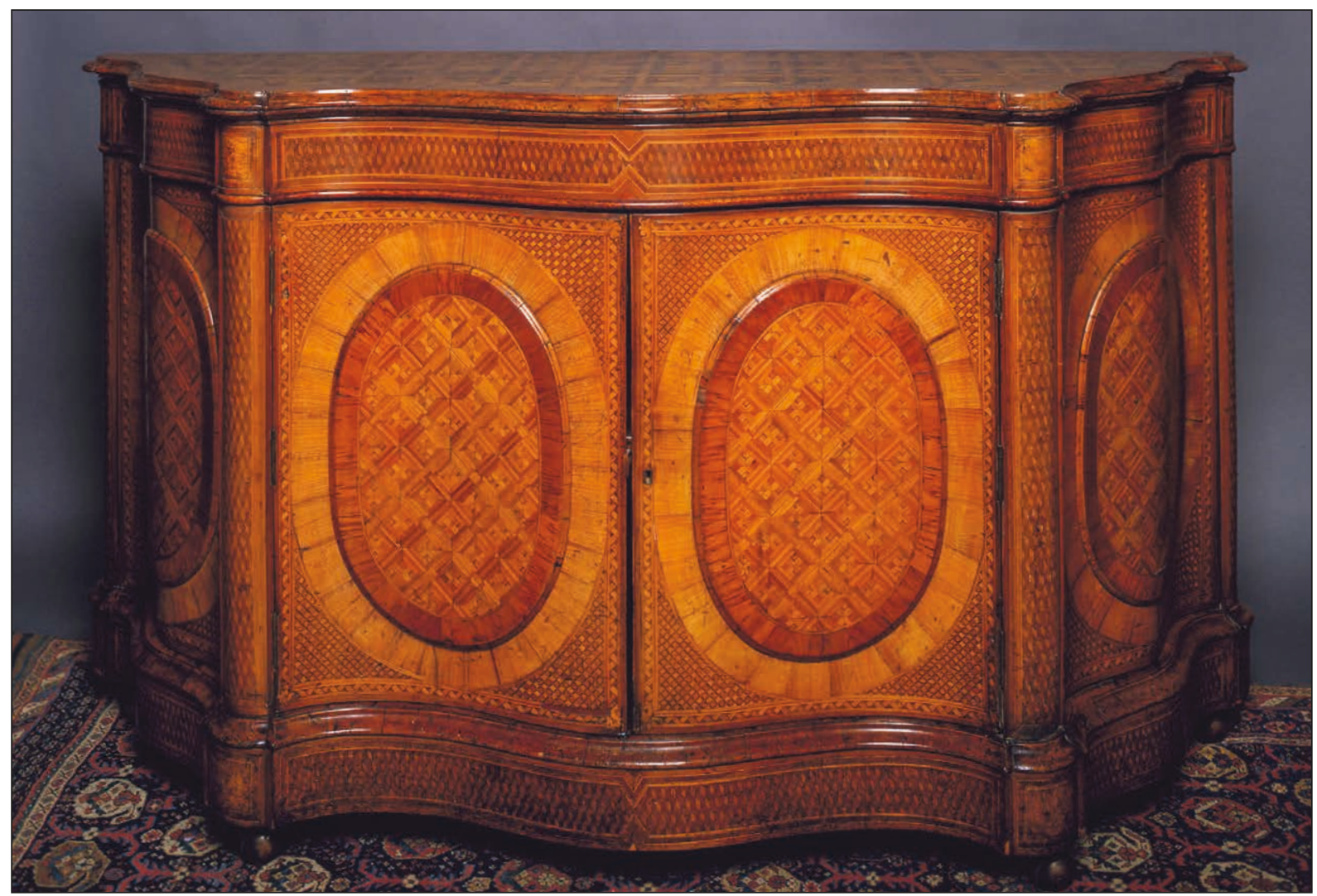

Figure 5. Commode of New Zealand native timbers, late 19th century. Attributed to Anton Seuffert. Mackelvie Collection, Applied Arts and Design, Auckland War Memorial Museum. F137. 
Zealand" (Mackelvie Trust Board Papers 1981). As a result, a decision was made to purchase the carvings for $\$ 5,000$ and retain them in New Zealand.

By the late 1980s, the Mackelvie Trust Board, returning to their interest in the fine arts collection at the Auckland Art Gallery, realised that they should shift their focus to more modern art works as the prices of 19th-century paintings became prohibitive (Mackelvie Trust Board Papers 1988). As a result, in the 1990s the Board's acquisition policy evolved to include early 20thcentury British works, which helped the collection gain a better representation of paintings from this period.

In 1997 Christopher Saines, then director of the Auckland Art Gallery, asked Mackelvie Trust Board Chairman John Wigglesworth (Chair from 1990 to 2011) to fund a part-time curatorial assistant dedicated to the Mackelvie collection (Mackelvie Trust Board Papers 1997). It was agreed that a major part of the Trustees' responsibility to maintain, exhibit and enhance the collection could be achieved by this dedicated Mackelvie curator. Mary Kisler, a specialist in Italian Renaissance art, was appointed to the position in May 1998. As part of the Trust's quarterly meetings, she presents reports on various activities related to the Mackelvie collection in the Auckland Art Gallery such as restoration projects, exhibitions, loans, and research on specific paintings.

It should be acknowledged that in the 21 st century all three institutions that house the Mackelvie collections are progressively developing and allowing free access to it as an ongoing process. This has involved the adding of new images and records, along with improving its online accessibility of this information to the public. This is a type of access that Mackelvie could only have dreamed of.

\section{CONCLUSION}

James Tannock Mackelvie's gift to Auckland was one of the most generous of the late 19th-century's bequests to civic institutions in New Zealand. Mackelvie chose to leave his collection to the city where his fortune had been made as a way of helping to bring about an improvement in the refinement and education of Aucklanders. The realisation of his vision would not have been possible without the significant role played by the Mackelvie Trust Board. Left in a difficult position upon Mackelvie's death with the requirement to build a gallery but not the means to do so, they have managed to steward the legacy into a world class collection of art, objects and books. Whilst the Auckland Free Public Library and Gallery had provided a safe repository for Mackelvie's art and book collection since 1887, it was not until 1929 with the opening of the Auckland War Memorial Museum that the Mackelvie decorative arts collection found a permanent home to further showcase the benefactor's diverse range of collecting interests. The first dedicated display at the museum was relocated in 2005 to establish 'The Mackelvie Collection' in the Decorative Arts Gallery on the first floor, and it remains to this day an integral component of the overall Auckland Museum experience (Fig. 6). This is due in part to the experience and expertise of the museum staff, but it also reflects the good stewardship of the Mackelvie Trust Board who remain dedicated to preserving Mackelvie's legacy for the enjoyment of future generations of Aucklanders and visitors to the city.

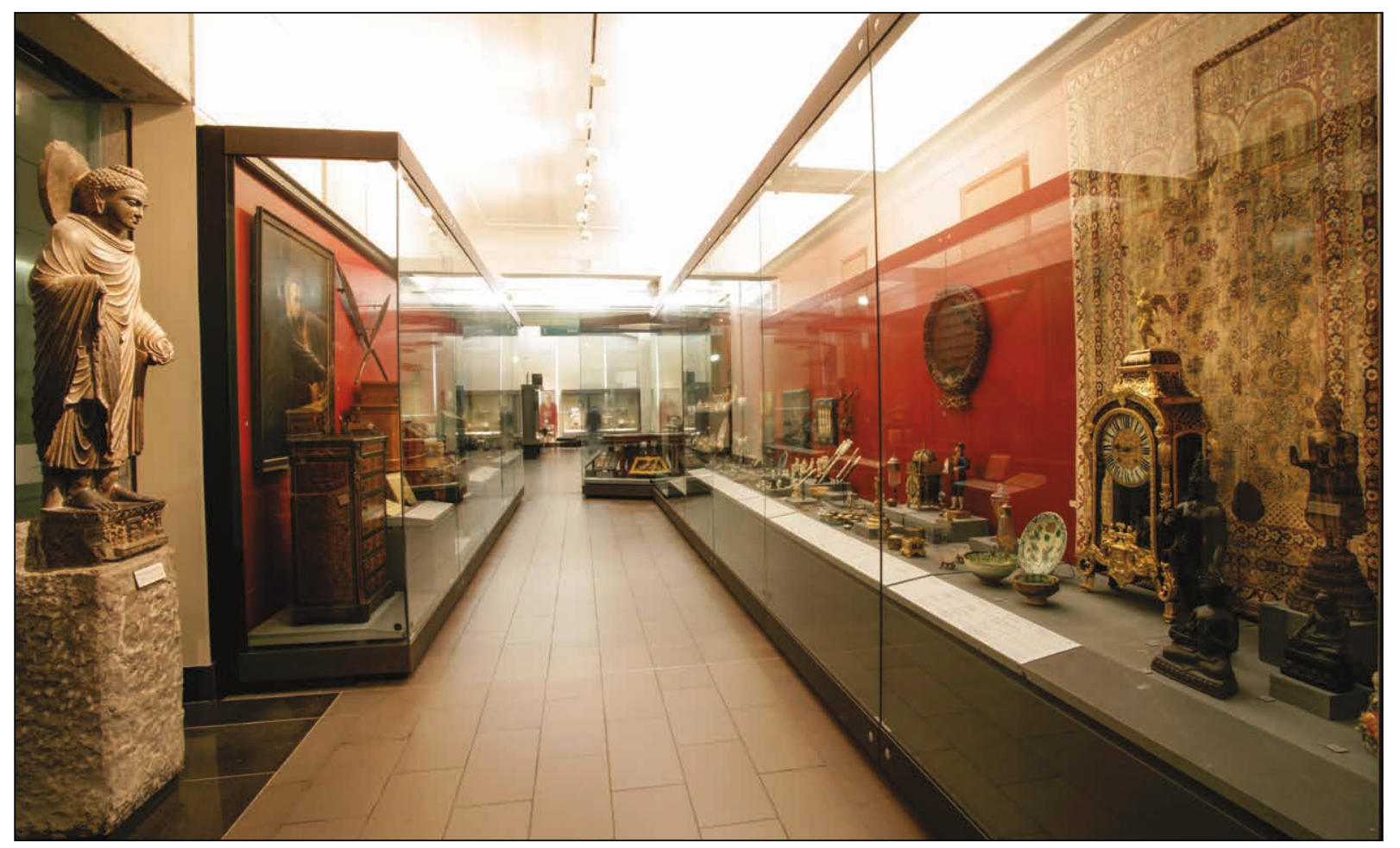

Figure 6. The Mackelvie Gallery, Auckland War Memorial Museum. Photograph by Krzysztof Pfeiffer. 


\section{REFERENCES}

Agreement on Mackelvie Art Collection. New Zealand Herald, March 111955.

Brown, Gordon H., 1981. New Zealand Painting, 1940-1960: Conformity and Dissension. Wellington: Queen Elizabeth II Arts Council of New Zealand.

Carroll, Penelope, 1994. Trust in Art. New Zealand Herald, August 251994.

Fairburn, A.R.D., 1947. Some reflections on New Zealand Painting. Landfall 1(1): 49-56.

Gamble, Brenda (ed.), 1971. New Zealand News. Art Gallery \& Museums Association of New Zealand 2(9): $11-17$.

Garrity, Tim, 1975. The Mackelvie Trust. Gallery Quarterly 60: 17-19.

James Tannock Mackelvie Papers, MS-51-142, Auckland War Memorial Museum Library.

The Mackelvie Collection: A centennial display of the Mackelvie gift of books (1985). EPH-2014-1954, Auckland War Memorial Museum Library.

Mackelvie Trust Board Papers, CL 06/10. E.H. McCormick Research Library, Auckland Art Gallery.
Mackelvie Trust Board Papers, NZMS 895, Series No. $2 / 1 ; 2 / 2 ; 2 / 3 ; 2 / 4 ; 2 / 5$. The Sir George Grey Special Collections, Auckland Central Library.

Powell, Arthur William Baden (ed.), 1967. The Centennial History of the Auckland Institute and Museum 1867-1967. Auckland: Auckland Institute and Museum.

Stacpoole, John, 1985. James Tannock Mackelvie and his Trust. In A. Bogle \& B. Muir, The Mackelvie Collection: a centenary exhibition, 1885-1985. The Mackelvie Trust: Auckland City Art Gallery; Auckland Institute and Museum, Auckland.

Stead, Oliver (ed.), 2001. 150 Treasures. Auckland: David Bateman/Auckland Museum.

Vennell, C.W., 1971. The Mackelvie Trust. Auckland: Wilson \& Horton Ltd.

Will of James Tannock Mackelvie, Westminster, London. 1877, December 21. BBAE, 1587, A48, 36, R8081626. Archives New Zealand, Auckland Regional Office.

Andrew McKay, University of Auckland. amck256@aucklanduni.ac.nz 



\title{
'Your list is certainly a formidable one': the Rev. A.H. Voyce and the Auckland Museum
}

\author{
Moira White Otago Museum
}

\begin{abstract}
The Auckland War Memorial Museum holds a large number of cultural objects, a collection of shells, and a group of butterflies, all collected by the Methodist missionary, Arthur Henry Voyce during his years as a Methodist minister in Bougainville in the period 1926-1958. His relationship with museums in New Zealand, and the background to the acquisitions is described.
\end{abstract}

\section{Keywords}

A.H. Voyce; Bougainville; Auckland Museum; Methodist missions; Otago Museum.

Voyce was born in Tasmania in 1899 but moved to New Zealand as a child with his family in 1907. He enrolled at Auckland's Trinity Methodist Theological College in 1923. Arthur married Beryl Haliday in the same month as his dedication - March 1926 - and the couple began what was to be over 30 years of missionary work on the island of Bougainville later that year.

A.H. Voyce amassed a very large collection of artefacts during his time on Bougainville, and facilitated collecting by other individuals and institutions. He was also an enthusiastic philatelist and conchologist. Voyce contacted the Auckland Museum in 1930, while he was in New Zealand during his first period of leave from the island, offering to place a quantity of material on loan there. The reply to this suggestion noted, "Your list is certainly a formidable one, and appears to be full of interesting articles, all of which, judging by the list, will be of good service here" (Auckland Museum to Voyce, 7 February 1930) and the conversation continued.

Voyce maintained his collecting, and contact with the Auckland Museum, through the 1930s and into the 1940s. The Australian Museum in Sydney, the Otago Museum in Dunedin, the Dominion Museum (now the Museum of New Zealand Te Papa Tongarewa) in Wellington, and Harry Beasley's Cranmore Ethnographical Museum in Kent also acquired material from him in those years. He is said to have provided much of the Rev. F. W. Brasher collection in the South Australian Museum, too (South Australian Museum and Hale: 204).

The Voyces were absent from Bougainville during the latter part of World War II. They returned immediately after, but collecting and museum contact seems to have been greatly reduced then. Arthur and Beryl retired to New Zealand in 1958.

\section{EARLY HISTORY}

An active member of his local Young Men's Bible Class group as a teenager, A.H. Voyce was recommended as a candidate for the ministry in the early $1920 \mathrm{~s}$. He enrolled at the Trinity Methodist Theological College in 1923 and offered himself for foreign mission work before finishing his course of study. Having completed three years at the College he was received on probation and at the fourteenth annual conference of the New Zealand Methodist Church, A.H. Voyce was dedicated to the work of the foreign mission in the Solomon Islands.

He married Beryl Haliday at the Methodist Collegiate Church in Grafton Road, Auckland on 17 March 1926. Beryl wore an ivy brocade crêpe de chine gown, and white georgette train with shell pink lining and silver lace. Her bouquet held white asters, dahlias, orange blossoms and maidenhair fern (Auckland Star, 26 March 1926: 12). Fellow students acted as Voyce's best man and groomsman. The couple sailed from New Zealand for Bougainville on the Mileusia (The New Zealand Methodist Times [NZMT], 14 August 1926: 14).

Named after (and by) the French 18th century circumnavigator Louis Antoine de Bougainville, the island of Bougainville was at that time part of the Mandated Territory of New Guinea, under the administrative control of Australia; a former part of Germany's colonial interests in the Pacific.

"It is a lonely and arduous outpost to which the Rev. A.H. Voyce and Mrs Voyce have gone", their colleague Allan Cropp wrote: "No finer work is being done today for God and humanity in the Pacific than by our devoted missionaries and their brave wives" (NZMT, 20 November 1926: 2). 


\section{ON BOUGAINVILLE}

Arthur and Beryl Voyce stayed initially with Cropp, who was appointed in 1921 (Luxton 1955: 111) at the Skotolan mission station while construction of their house was underway at Tonu, in the Siwai area to the south of the island. Voyce described visits to oversee the work: "We had to get the huge uprights and cross-bars cut from the bush... We got the post holes dug and the uprights in... The boys, under the guidance of the teachers, are to have the floor in, the roof on, and the walls up by the time we go again in about six weeks".

Maritime access was challenging. Voyce described an attempted landing:

\footnotetext{
"Mrs. Voyce and I went and got through safely. The next load capsized in a huge breaker, and a big safe and a horsehair bed and other things went floating off on the surface of the water... other things - a kerosene tin of rice belonging to the boys, 3 boxes and plants of ours, and a valuable portable gramaphone [sic] - which was proving such an asset and a blessing in our work - all went to the bottom of the ocean, never to be recovered. Naturally we were somewhat upset, but losses and trials of this sort are, I suppose, just some part of the missionary's life." (Open Door 5 (3): 3-6)
}

The Reverend and Mrs Voyce settled into their newly built house, planted a range of crops, started a school for local children, held church services and offered some medical treatments for the nearby population, such as dressing wounds, tropical sores and skin diseases. Beryl had attended a St John's course in Auckland but gained midwifery experience on the island.

In November, under the heading 'Cheerful in the midst of inconveniences', A. H. reported that in their first two months he had walked approximately $286 \mathrm{~km}$. $\mathrm{He}$ also noted the number of daily patients attending their clinic for treatment of sore, ulcers, boils and skin diseases had risen from 117 in their first week to 169 in the third, "It soon gets noised abroad that there is a free dressing of wounds at the Methodist Mission". He said they had already run out of crysophanic acid (which they mixed with kerosene to treat ringworm), and would appreciate the donation of an ear syringe. He added that as their bath and stove had not yet arrived Mrs Voyce was having to do all their cooking over a camp fire outside, and that they had run out of both dripping and butter (NZMT, 12 February 1927: 12).

A replacement for the mourned gramophone was received in 1927, at the end of which year there was a special request for cricketing gloves. He also suggested that gifts of calico and soap, beads, knives and mouth organs would be appreciated.

Writing of Bougainville in the 1930s, the American anthropologist Douglas Oliver noted that "Like the Marists the Methodists based their operations principally on stations, somewhat isolated from the indigenous communities, where youthful converts boarded, worked, attended school... the education included training in agriculture and industrial arts" (Oliver 1973: 117). This seems close to the situation Voyce described; Oliver's description may even be based on Tonu.

There were regular periods of furlough in New Zealand, and travel off-station also occurred for social and professional reasons. Soon after their arrival in 1926, the Voyces were best man and matron of honour at the wedding of the Revd Hubert Brown and Miss Irene Crespin at Numa Numa, on the island's east coast, on which occasion Mrs Voyce wore a dress of apple green crêpe de chine. A.H. attended the annual Methodist Synod meetings. At the Solomon Islands Synod in Roviana in 1928 he gave a trial sermon and was examined on his book list (NZMT, 9 February 1929: 12). In 1929 he described a fortnight's exploration into the 'wilds of the mountains' (NZMT, 21 September 1929: 10). The purchase of a surf boat, Te Oranga, earlier that year greatly reduced the time and effort involved in a trip to the Buin Police Post to collect mail and cargo: 20 hours by sea for a journey that was 80 miles (c. $129 \mathrm{~km}$ ) by road for the round trip (NZMT, 21 September 1929: 10). The rest of the world must have seemed a little less distant.

\section{CONTACT WITH AUCKLAND MUSEUM}

Arthur Henry Voyce was ordained in 1930. The couple (and their first child) were on leave in Auckland in the early part of that year, while the Reverend Tom and Mrs Dent lived at Siwai in their absence (NZMT, 5 April 1930: 15). Furlough involved a certain amount of deputation work and Voyce had vocational commitments, as well as enjoying time with family and friends. Beryl Voyce spoke to a number of Women's Auxiliary groups. Belshazzar Gina was still in New Zealand then, having been accepted as a candidate for the Methodist ministry in 1929. Gina was well known in Church circles, and he and Voyce visited the Taipowhenui pā near Hawera together. Following a welcome by the Revds R.T. Haddon and Piripi Rakena, both men spoke: Voyce about the mission work on Bougainville; Gina more personally about his father's conversion to Christianity and the effect of Christianity on his people (NZMT, 5 April 1930:10). Voyce also give an illustrated address at Te Awamutu in March, and spoke in Pahiatua, Makomako, New Plymouth, Takapuna and in Wellington, where he spoke to a Methodist Auxiliary meeting on the impact of Christianity on his mission district, and "...had many interesting curios to show, illustrating artistic handicraft among the people. A collection of beautiful butterflies also excited attention".

He took advantage of being in New Zealand to ask Sunday School Superintendents if they would donate materials for the Bougainville mission kindergarten teachers to use: picture cards, Plasticine, coloured papers, scissors and crayons; razor blades, rulers, whistles, pocket knives, belts, tennis balls or marbles (NZMT, 19 April 1930: 16). He also mentioned that a compass and a strong tent would make life more comfortable when he, Mrs Voyce and their baby were travelling in mountain areas; and that sets of slides for the magic lantern they had already received, would be well used. 
Voyce also made contact with the Auckland Museum It was during this period of leave. He wrote offering to place a quantity of material on loan there, and received an encouraging reply, "Your list is certainly a formidable one, and appears to be full of interesting articles, all of which, judging by the list, will be of good service here" (Anonymous, Auckland Museum to Voyce, 7 February 1930). The Museum arranged to have a Checker Express van call at the Voyce's Mt Eden address to uplift the collection. Gilbert Archey saw it when he returned from leave and wrote to tell Voyce he had shown a selection to members of the Institute Council, but suggested the return of some objects that he felt were already well represented there. A week later Voyce replied from Hamilton, asking for a list of the pieces that were to be retained by the Museum. He also mentioned he had more material with him, including a Fijian whale tooth necklace that he had obtained by exchange from Australia (Fig. 1). The two men discussed meeting when Voyce's deputation work in the North Island was completed.

The Rev. and Mrs Voyce left New Zealand in early May (NZMT, 17 May 1930: 14). Back in Bougainville, Voyce was eager to continue - to increase - his collecting activities. He was travelling more widely, negotiating passes in the Crown Prince Range which brought him into contact with the people of the Kongara, Kieta and Luluai Valley areas. At one point he reported that in nine days he had walked nearly $210 \mathrm{~km}$ in the Nagavisi and Baisi districts.
He described his collection of "stone implements from various islands... I have close on 200 here. Then there are some big things such as carved posts, wooden drums, etc which I would send if Captain Burgess could pick them up in Kieta - about May of 1931" (Voyce to Archey 24 October 1930). Burgess was then captain of the Southern Cross, the Melanesian Mission steamer. Not long after, Voyce wrote asking for "a few lines in writing to the effect that, should I require them [items from his collection at the Museum] any time in the future they will be made available. I don't anticipate requiring them for some considerable time, but it seems to be merely a business proposition to have this arrangement definitely in writing... Also, should I desire to insure the collection against all risks, can I do this through you?'(Voyce to Archey 26 October 1930)

The following year he wrote,

"I secured some fine old stuff from New Guinea hinterland recently, including one of the finest stone clubs on original handle I have ever seen. - also a couple of fine axes on original handles \& a very fine dogs' teeth \& shell breast ornament. Have also got some new things from other places, including an original stone fish from Buka \& the whole story of its use in the peoples' fishing culture. The stone fish I left in the Auckland Museum was a model (on a very large scale) of the original small ones, so sacred in the cult..." (Voyce to Archey, 21 May 1931). (Fig. 2)

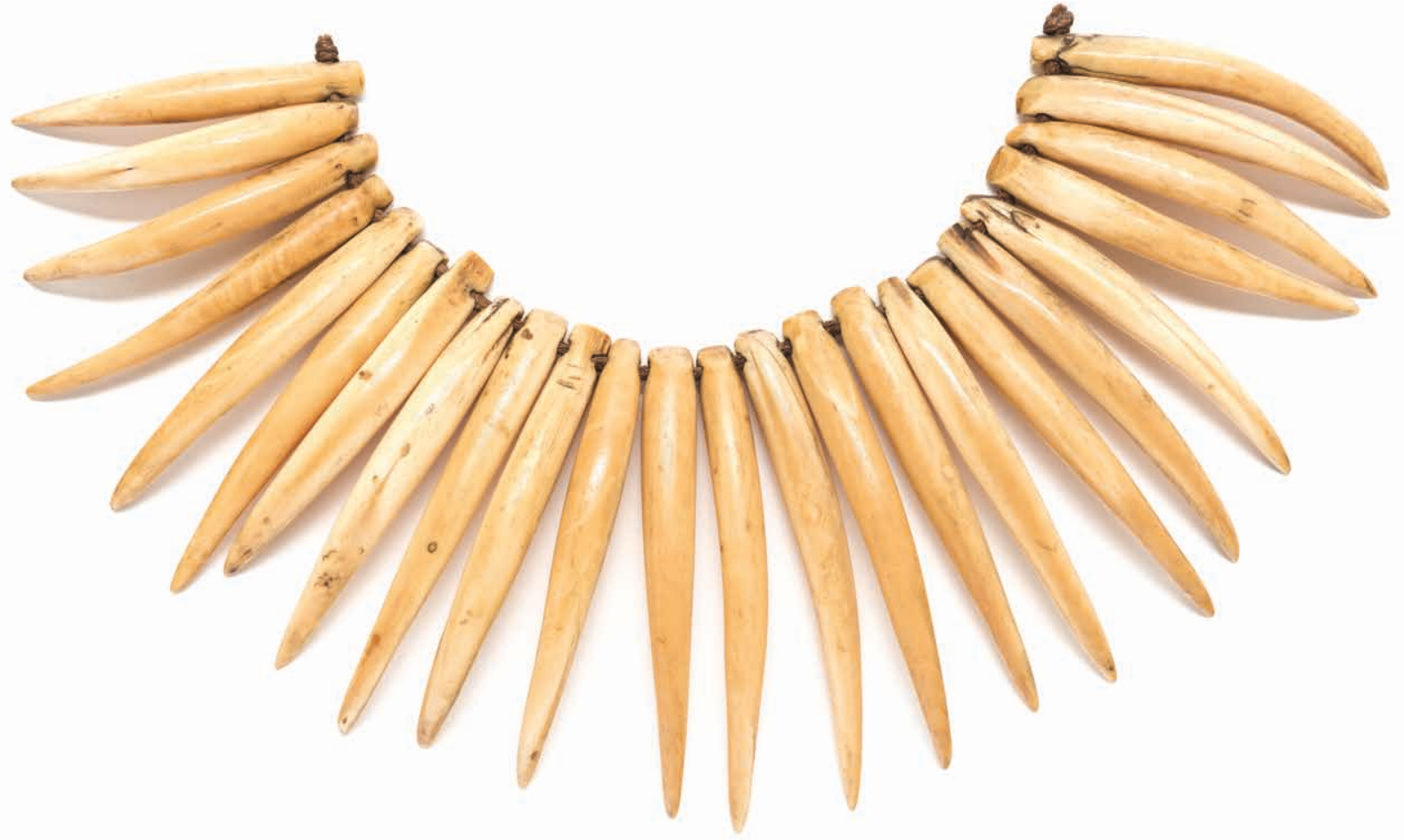

Figure 1. Wasekaseka. Auckland War Memorial Museum. 1930.16, 13661. 


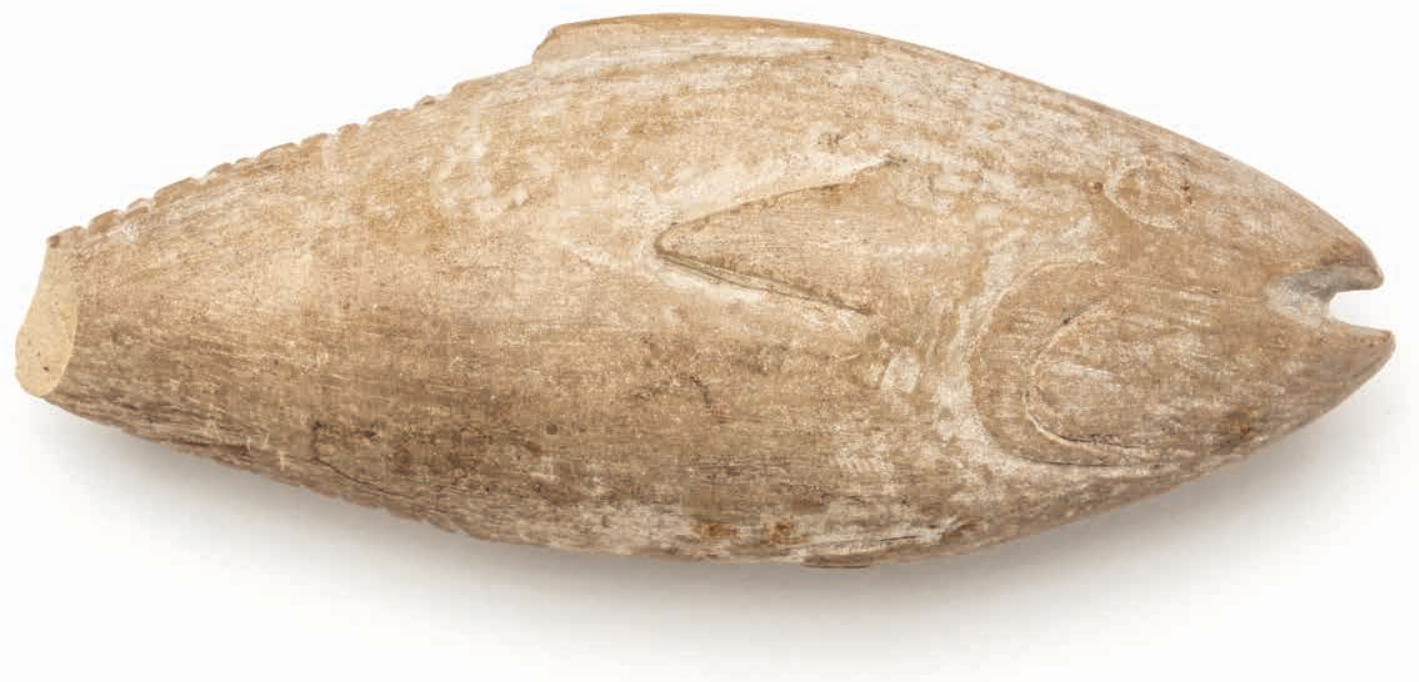

Figure 2. Atun. Stone fish, Petats Island, Solomon Islands. Auckland War Memorial Museum. 1934.145. 24195. Oxford anthropologist, Beatrice Blackwood, spent a year in the north of Bougainville over 1929-30, and seems to have had more contact with Cropp than with Voyce (1935: viii). She wrote that "the stone models of fish used in bonito magic (now sometimes replaced by the more easily manufactured wooden ones) are the only examples known to me of figures made of stone" (Blackwood 1935: 438).

The Southern Cross schedule did not include Kieta that year and Voyce said, 'I have not purchased the items yet - so I think it would be best to leave the matter in abeyance for a time. My own collection is of course rapidly mounting up - the stone implements are now going on for 800' (Voyce to Archey, 21 December 1931). He also offered to try to obtain particular items from the Solomon Islands or Papua New Guinea that Archey felt would be important for the Museum. Little specific guidance eventuated, Archey explaining 'it is really difficult for us to know here what to ask for, of course, there is such an amazing variety of articles made in Melanesia, and we have hardly sufficient detailed knowledge to be able to specify any one article. Generally speaking we are glad to get any genuine old article and would always be glad to receive examples of the commoner stone adzes from the different districts' (Auckland Museum to Voyce, 7 April 1932).

The Voyces' next period of leave was planned for late 1933. A.H. suggested to Archey that he deposit another large group of material at the Auckland Museum. In his reply, Archey mentioned the issues of storage space and the staff time involved in cataloguing, numbering and labelling. He raised the questions of tenure and possible acquisition:

"...we should like to be assured that the collection will remain for a long enough period for us to take advantage of it as comparative study material and for display. Of course we are hoping that it will, in the end, form part of our permanent collection as your gift..." He finished, "I therefore look forward with much interest to hearing your views on the ultimate permanent home of your collection" (Archey to Voyce, 31 March 1933).

Voyce responded that he was inclined to consider the suggestion if they could agree on the terms. He expressed a preference for the collection to remain intact. Despite Archey's tentative mention of a gift, Voyce was clearly interested in sale, rather than donation. "If I sell it", he wrote, "I will then be able to acquire during my further residence in New Guinea, a very much more extensive collection than I could otherwise do. Of course I always intended to continue to collect, but my resources are not large (I have only my missionary stipend - enough said) \& so the collecting would always be limited" (Voyce to Archey, 27 September 1933).

In New Zealand, two weeks of deputation work in South Canterbury was scheduled in September, followed by six weeks travelling in Otago and Southland. A lantern lecture titled 'Pioneering Amongst the Forest and Mountaineering Tribes of Bougainville' was given in the Temuka Methodist Church (Press, 19 September 1933: 6). Another at the Methodist Church in Rakaia attracted a large audience (Press, 16 September 1933: 5). Topics discussed at a well-attended lantern lecture in Ashburton included 'scenic attractions, climatic conditions, the products of the Islands, [and] difficulties encountered through grievances and superstition...' 


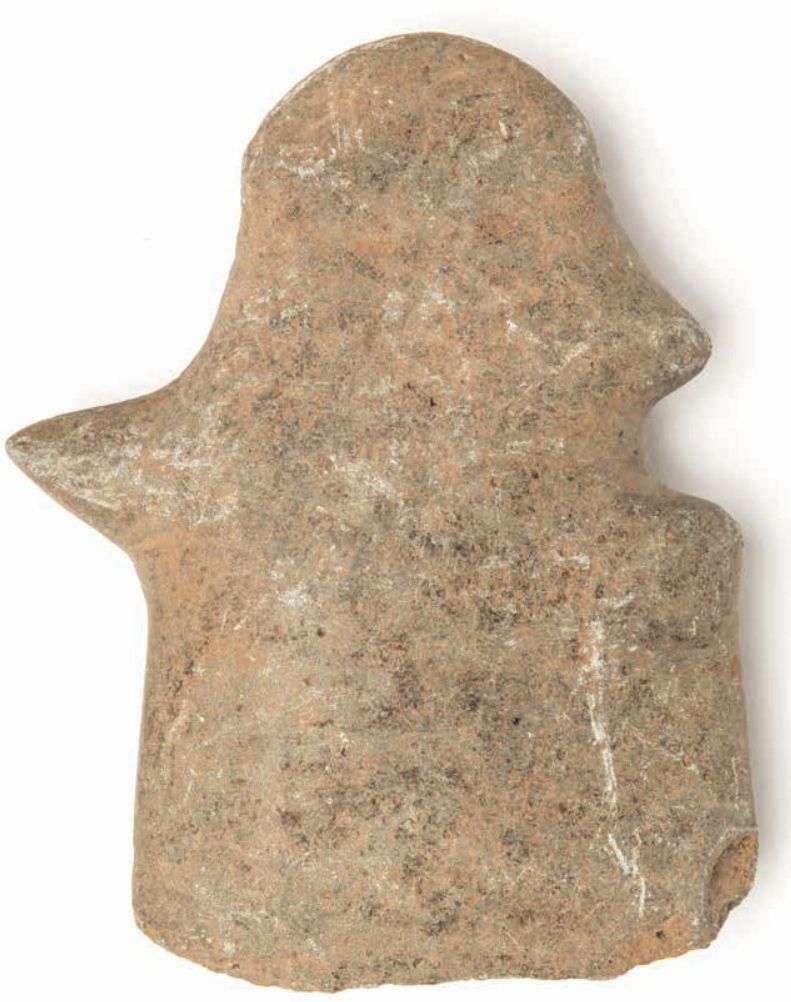

Figure 3. Adze. Roviana, Solomon Islands. Auckland War Memorial Museum. 1930.16. 38427.
(NZMT, 30 September 1933: 14) It closed with a display of 'specimens of native handiwork, shells, and butterflies' for sale: 'Good business was done' (NZMT, 30 September 1933: 15). His missionary meeting in Geraldine was described as 'luminous and informative'.

An advertisement headed 'Sale of Mission Curios' the following month (NZMT, 14 October 1933: 10) advised readers of the New Zealand Methodist Times that the Revd A.H. Voyce had brought with him to New Zealand 'large quantities' of basketry trays and mats (priced from between one and five shillings depending on size and style), plaited fibre work (including serviette rings), 'native necklets' of flying fox or opossum teeth (for one or two shillings) (Figs 4 and 5), 'wonderfully made' spear heads (five shillings each), and small, medium or large tropical shells, including cowrie or nautilus (from threepence to a shilling each). These items were being sold to raise money for the Missionary Society's Fund.

In Otago, Voyce delivered "a splendid address at a Foreign Mission anniversary service in Maheno", showing "numerous beautiful images of island scenes", after which "a wide range of native art and craft work" was exhibited (Otago Daily Times [ODT], 23 September 1933: 16). He spoke in Cromwell in early October. One apparent outcome of this engagement was the donation of a gramophone and thirty records to the Bougainville mission (NZMT, 9 December 1933: 14). At an evening lantern lecture in Palmerston the following month, 'Gorgeous tropical butterflies, beautiful shells, rare and intricate native

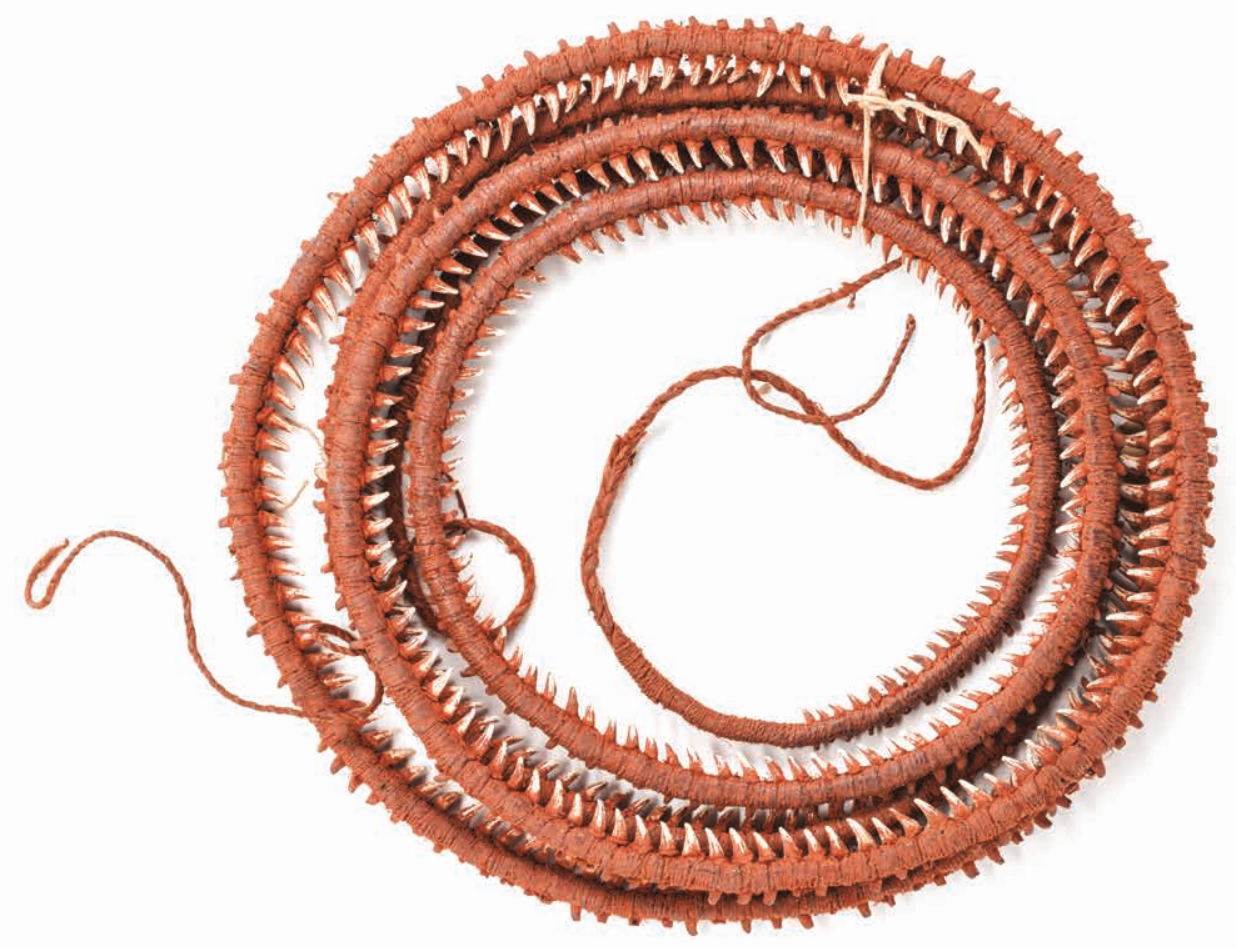

Figure 4. 'Flying fox teeth worked onto string and coloured with red pigment. Value of this currency f2'. Petats Island, Buka. Auckland War Memorial Museum. 1934.145. 20164. 


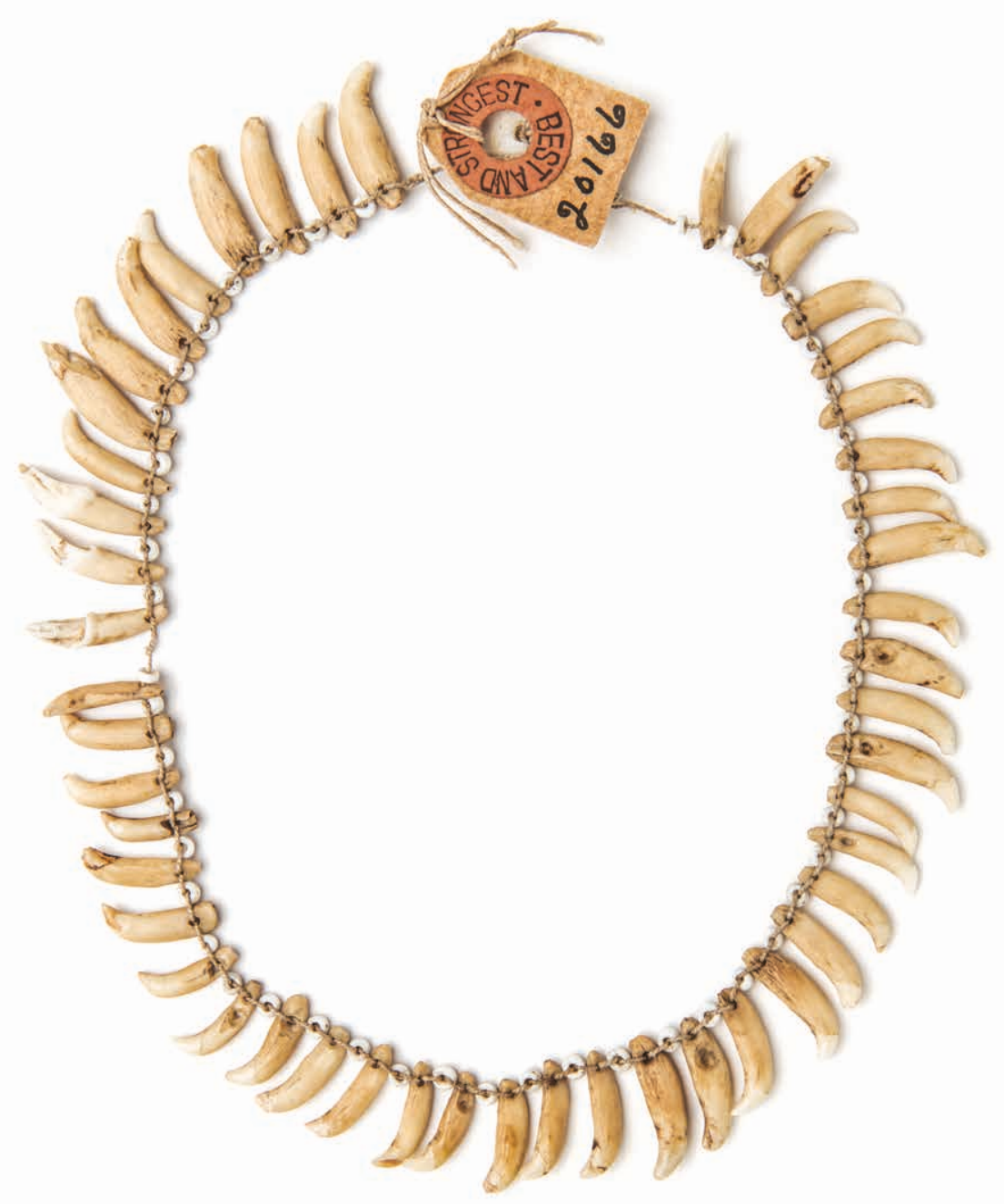

Figure 5. Neck ornament of teeth. Kunu Village, Siwai Distict, Bougainville. Auckland War Memorial Museum. 1934.145. 20166.

arts and crafts, the dreaded Kundu drum, and a hideous maneating crocodile, were among the novel sights shown' (ODT, 4 November 1933: 16). (Figs 6 and 7).

Later in November Voyce spoke at an 'at home' held in the Young Women's Christian Association club room in Christchurch, as part of an international week of prayer. He mentioned Bougainville's increasing economic importance due to gold and copra exports, and described the fauna as "grand and gorgeous, yet often repulsive" (Press, 17 November 1933: 2).

The Methodist Women's Missionary Union was held in Dunedin in 1933. Voyce attended and met H.D. Skinner of the Otago Museum while in the city. The encounter seems to have helped clarify his feelings on issues regarding his collection. He wrote to Archey soon after that Skinner,

“...showed me very proudly his Solomon \& Maori collections, (some classified in types something after the method I had hoped to pursue). I noted numerous articles on display, stone artifacts etc,
...\& I happened casually to mention the fact that I had brought home a collection of North Melanesian artifacts to the number of 1500 to 2000. He stood in amazement \& we talked much of stone implements. I told him that you had asked if I would consider its being acquired by purchase, by the Auckland Museum. He begged me to let him have a portion of the collection \& made a generous offer for a portion of it, without seeing any part of the collection. Of course I explained that it was impossible for me to treat for even a portion of the collection without first discussing the matter with you... He says that if they are able to acquire a portion, the collection would be open to me at any time for study purposes. Now, I merely mention this matter, so that in making an offer, you can please yourself whether you make an offer for it in whole or in part... Mr Skinner is going to give me much assistance on my return, in discussing classification of stone artifacts, etc ..." (Voyce to Archey, 27 September 1933) 


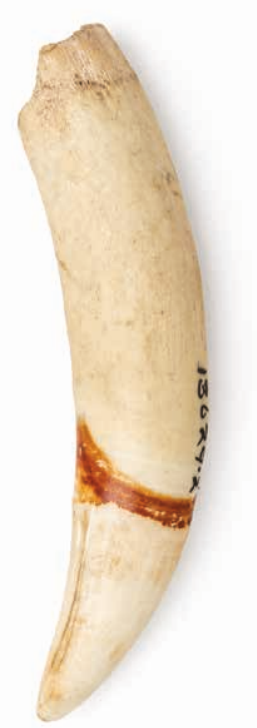

Figure 6. Kevi, crocodile tooth. Siwai District, Bougainville. Auckland War Memorial Museum. 1930.16. 13629.2
He preached at Methodist churches while in Dunedin including Dundas Street Methodist and the Cargill Road Methodist Circuit (Evening Star, 28 October 1933: 19).

Near the end of the year Voyce asked Archey directly if he was prepared to acquire his collection: "If you desire to make an offer, will you offer for the whole collection or will you have to consider a part being secured elsewhere? ... If it is a case of awaiting some Board meeting I would be glad if you would write briefly immediately, giving some indication of your opinion one way or the other, so that in the event of my early return to the islands I may have time to consider what I should best do in regards to the collection: (Voyce to Archey, 20 December 1933). This having first noted that he had received "an enquiry from the Cranmore Ethnographical Museum - Kent - England - but I don't propose to reply until I hear from you". (ibid.)

Shortly after, before he left New Zealand, he set a price and wrote agreeing to sell the material then on loan to the Auckland Museum to them for $£ 250$, on three conditions:

- that it be known as "the Rev A.H. Voyce collection, acquired by purchase";

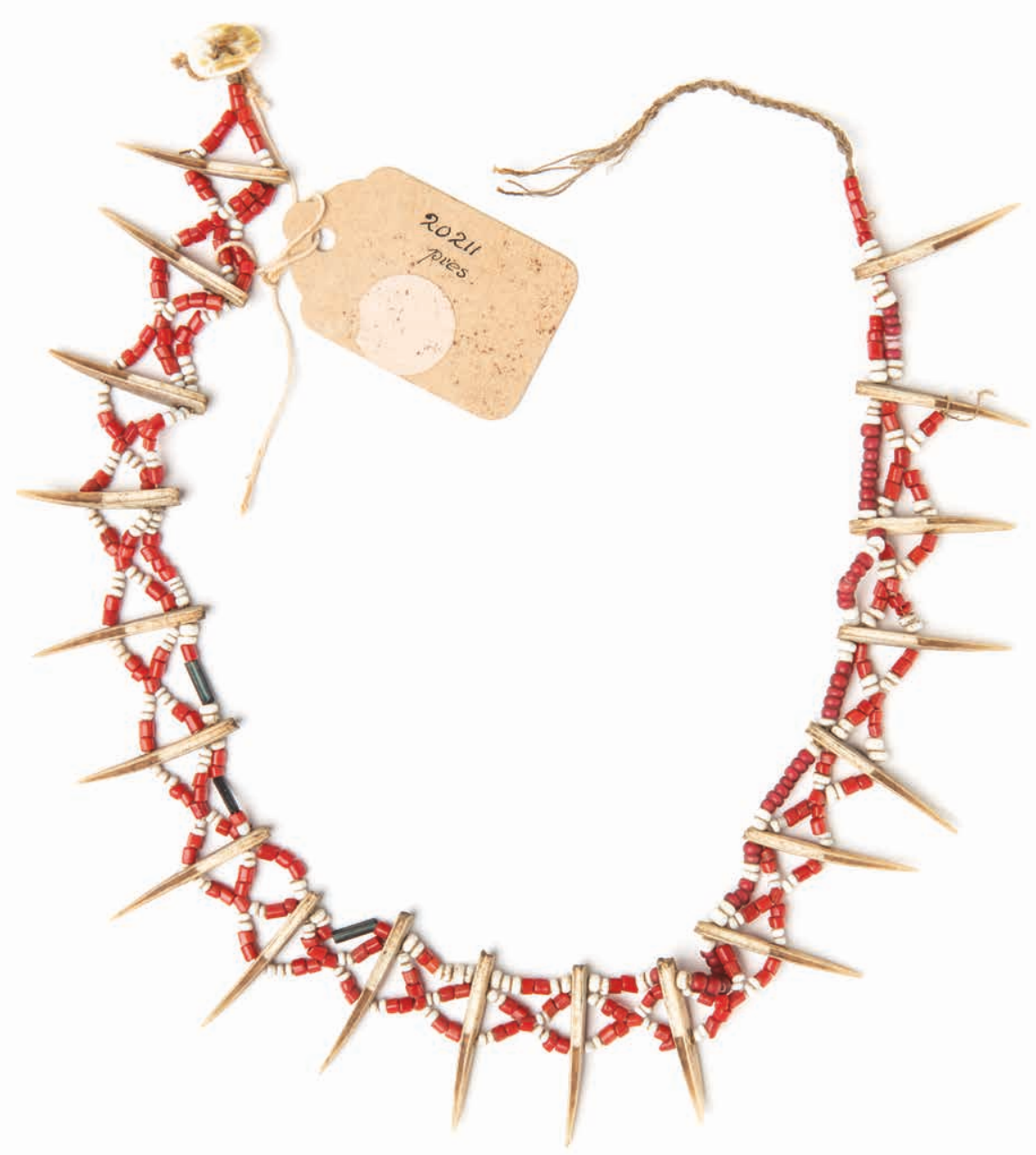

Figure 7. Neck ornament of sail fish teeth and glass trade beads. January 1931. Musiminoi, Siwai District, Bougainville. Auckland War Memorial Museum. 1934.145. 20211. 
- that he should have free access to it at any time for study or comparison; and

- that the Museum would supply him with a detailed listing of the collection when registration and cataloguing was completed (Voyce to Archey, 22 December 1933). The matter was with Archey for resolution, and he successfully sought external funding. Details of payment were agreed and a schedule finalised in 1934. Photographs of five items from Voyce's collection made up an illustrated page in the Museum's Annual Report for that year (Annual Report of Auckland Museum 1934: 9). Since the purchase was financed by another source, however, it was reported as an:

\footnotetext{
"important and generous gift... of a collection from Northern Melanesia presented to the Museum by a prominent citizen. This collection, which consists of over 2,000 specimens, comprises a wide range of articles, all carefully documented, among them being many types of ornaments, carvings and implements, and, in particular, a very extensive and compete collection of all types of stone adzes" (Auckland Museum 1934: 13).
}

The following year, the donor of an "extensive ethnographical collection from Northern Melanesia" in 1933 was named as Mr (later Sir) William Goodfellow,

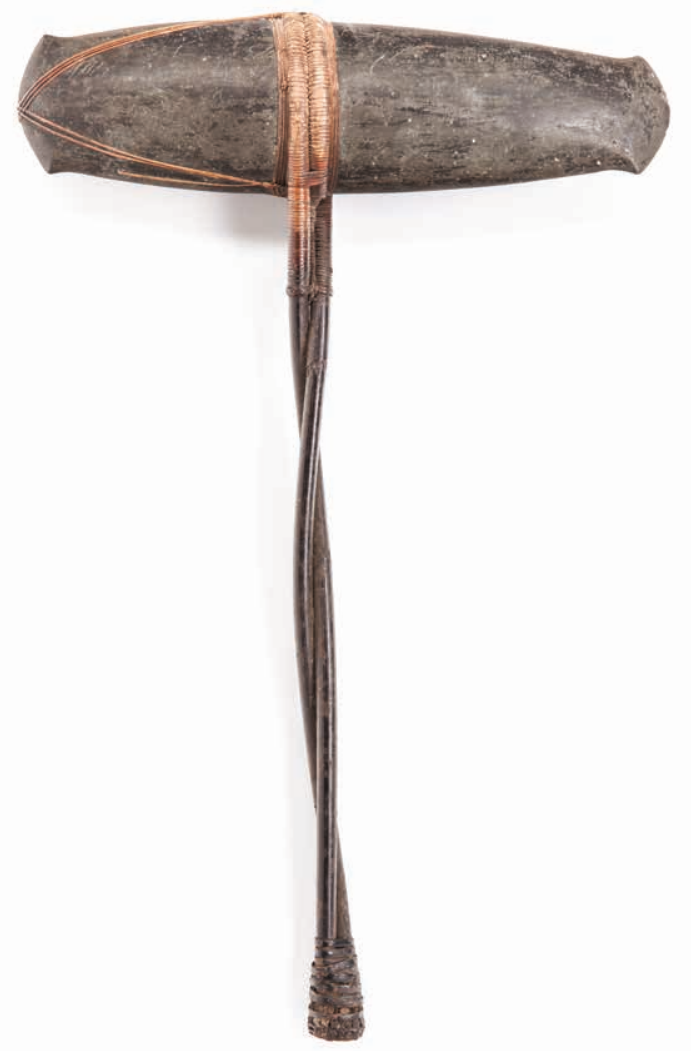

Figure 8. 'Hafted stone adze. ...beautifully shaped and flared at both ends. Polished, original handle.' Koaka, Kunua District, North Bougainville. Auckland War Memorial Museum. 1934.145. 20554. a Life Member of the Auckland Institute (Annual Report Auckland Institute and Museum 1935: 33). [accession number 1934.145].

Voyce, meantime, was still making contacts; still, apparently, anticipating the expansion of his collection. Skinner had given him a letter of introduction to Walter Reginald Brook [W.R.B.] Oliver, Director of the then Dominion Museum (now Te Papa Tongarewa Museum of New Zealand). Their first attempt at meeting didn't eventuate but early the next year Voyce wrote to Oliver (8 January 1934) from Buin to say he was sending "on deposit" some teeth necklets and bamboo combs "to serve as an introduction from here". He continued:

"I collect for several well known museums in NZ \& Australia, \& also for Cranmore Eth. Museum, but even so I am able to often secure duplicates to an extent not often desired by these institutions. Would your institute be agreeable to receiving genuine native arts, curios etc of Ethno. value \& interest, with place of origin, native name $\&$ all particulars given with the numbers, on deposit - with a view to purchase later... I write to know before purchasing much stuff, as I don't want too much left on my hands... Conditions would be that if you desired to receive a large lot on deposit, that you should pay shipping charges, $\&$ also that any big articles, too large for packing in cases etc, such as wooden gongs

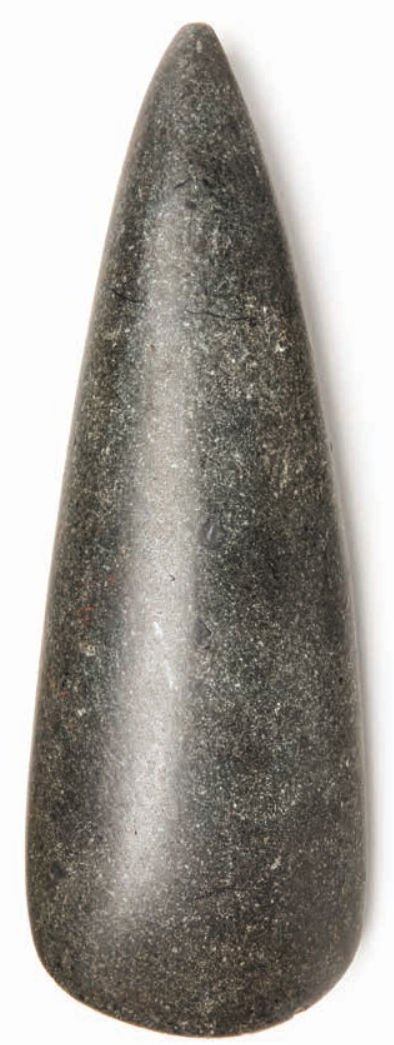

Figure 9. Kahaku, stone adze. Morone, Siwai District, District, Bougainville. Auckland War Memorial Museum. 1934.145. 20915. 
etc, would automatically become the possession of your museum, upon your defraying outgoing expenses". (ibid.)

Back in Bougainville, he wrote to Vic [Victor Frank, or V.F.] Fisher in Auckland, "I visited Aust Museum. They have very little Bougainville stuff. - Only a few adzes - ordinary type 1A. - \& only two kunua type 1 A. Very little other stuff. I was amazed at the smallness of their B \& B [Bougainville and Buka] section" (Voyce to Fisher, 5 March 1934).

Later in 1934, Voyce told Archey, he would be spending a year in Teop, further north (Voyce to Archey, 3 September 1934). Contact continued in the early part of 1935, with discussion of further possible acquisitions and Voyce's preparations for his paper, 'A Classification of the Wood-working Tools of Bougainville', to be delivered at the Fifth Science Congress of the Royal Society of New Zealand, in May (Anonymous 1936: 454). He also planned to present a classification of Bougainville kapkap (ibid.) The content for the former may have been drawn from a manuscript on the stone wood-working implements of Bougainville and Buka he offered to the Journal of the Polynesian Society [JPS] (Voyce to Archey, 24 January 1935) but declined, possibly because of its size and number of illustrations (Archey to Voyce, 22 March 1935). At the 1935 Solomon Islands Synod held in Buka, A.H. was elected Assistant Secretary.

In 1936, the Voyces moved again, to the southern coast of the main island, and began the work of establishing a new c. 150 hectare Head Station for south Bougainville at Kihili. They hosted 200 people for Christmas celebrations in December, which began with a 6 am service. Voyce planned to grow rice and peanuts, among other crops. With building of various structures and facilities underway he wrote in 1937, "work presses so hard one hardly knows what to do first, houses, roading, bridging, fencing, gardens." He was contending with his own physical limitations at the same time, having dropped a heavy log on his toe, crushed one thumb in a wire strainer, and suffered from patches of obstinate tropical ringworm.

In 1937 the annual Synod meeting was held at Sasamuga, Choiseul and at the end of that year the Voyces were again on furlough in New Zealand. As usual, A. H. travelled to fulfil his deputation obligations, and maintained communications with his museum contacts. He wrote to Walter Oliver at the Dominion Museum to let him know he would be attending the conference of the Methodist Church in February 1938, and hoped to be able to meet him then in Wellington. He exhibited a 'strange variety of articles of native craftsmanship' at one Auckland speaking engagement. In May he gave a lecture on the development of airfields in New Guinea to an Auckland Institute audience (New Zealand Herald, 26 May 1938: 22), and he was again negotiating the sale of a large number of artefacts to the Auckland Museum; this time his 'recent collection' of stone implements:

"You bought my last collection of about 1200 I think. This is a collection of more than twice that size - specialised - largely of Bougainville \& Buka - but containing many new types - also a comparative collection of many very unusual types from Choiseul \& New Georgia for comparison with B. \& Buka. Also some 40-50 very fine Mt. Hagen axes from New Guinea. All are catalogued as heretofore. I want $£ 360$ for the collection...

Also I have some books as under which I wondered if the Institute Library would be interested to consider for purchase..." (Voyce to Archey [6] May 1938)

The books included Guppy (1887), Ivens (1927), Meyer and Parkinson (1900), Beasley (1928), and Naven (Bateson 1936). Voyce was obviously familiar with the writing of collectors, missionaries, anthropologists and travellers in the area in which he lived.

By June he was reported to have completed a "very successful deputation itinerary of South Auckland, Auckland and Hawkes' Bay-Manawatu Districts" (NZMT, 4 June 1938:6). The two older Voyce children remained in New Zealand to attend school when A.H. and Beryl returned to Bougainville.

Matters were not finalised until the following year. Archey wrote:

\begin{abstract}
"It would hardly to right to say that I was disappointed, for no one appreciates more than I do the scientific value of all this localized material; but it does appear to me that there is a great deal of material of one type, more so, I must confess, than I had expected...
\end{abstract}

I may add that if the collection had included more of the articles other than adzes, that is to say, if the articles which I have been able to show the Council had themselves been able to make a wider appeal both to the members and, through our exhibition halls, to the public, the Council would, I am sure, be far more ready to pay the higher price and if, in future, you are able to send us on approval for purchase any articles of the type I have indicated, I am sure the Council would view the possible purchase in a liberal spirit. You will understand when I tell you that it is the long series of apparently quite uniform material, not all of it perfect, which fails to make an appeal to those who have the ultimate and important task of finding the money." (Archey to Voyce, 27 June 1939)

Nevertheless the purchase went ahead. 'Old friends' E. Earle Vaile and Mr Goodfellow were both credited with the gift of an 'important Solomon Islands collection' in the 1939-40 financial year (Annual Report of Auckland Institute and Museum 1940: 6, 33, 36; accession numbers 1940:101, 1940:102).Vic Fisher reported that as a result "Much time was devoted to the registration of a large collection of stone adzes from the Solomon Islands and New Guinea" (Annual Report of Auckland Institute and Museum 1941: 14). The Dominion Museum in Wellington, and the Otago Museum in Dunedin also purchased artefacts from Voyce in the late 1930s. 
Near the end of 1940 Voyce wrote to Fisher that he expected to be in New Zealand on furlough around July 1941, bringing with him "such articles as you have indicated a desire to have the offer of, e.g., shell ornaments, fish hooks, wooden carvings, pestles, mortars, fish traps or any kindred articles." He finished, "I have noted that you do not desire bows, arrows or spears, nor any further stone implements unless of new types" (Voyce to Fisher, 27 November 1940). Six items were purchased from Voyce in 1941 (Accession number 1941.157; L. Furey, pers. comm, 2018).

Voyce seems to have assumed that he, at least, would return to Bougainville after this period of leave. The advent of the Pacific War, however, meant the decision was taken out of his hands. Japanese forces landed on Bougainville while the Voyces were in New Zealand. During his enforced absence from the island, A.H. initially spent some time lecturing - to church groups, Rotarians, the Travel Club, and groups of American servicemen in New Zealand. For some of these engagements he apparently borrowed objects he had sold to the Auckland Museum, to use as illustrative material. The Museum wrote mid-year to remind him to return items they had lent him in March, as the "times of emergency necessitate frequent changes in the arrangement of our collections" (Auckland Museum to Voyce, 29 June 1942).

Early in 1943 he suggested the sale of his collection of bamboo boxes. These he said were "acquired 8 to 10 years ago. All are from Bougainville \& form an exhaustive collection of types $\&$ designs. They cost from $2 /$ - to $7 /$ - or $9 /-$ each... The collection is for sale as a whole \& is not open to breaking up..." (Voyce to Turbott, 12 April 1943). They were acquired the following year (accession no. 1944: 75). In May he spoke at a missionary rally to mark the forty-second anniversary of the founding of the Methodist Mission at Munda, New Georgia, in the 'stricken Solomon Islands', described as the Superintendent of Japanese Occupied Bougainville (Auckland Star, 20 May 1943: 8).

Not long after, however, he wrote of his almost immediate departure for Melanesia, saying he was "urgently recalled from the South Island by the Army Authorities examined \& passed yesterday \& I leave by plane in a day or two for the Pacific as Chaplain" (Voyce to Auckland Museum, 24 August 1943). Voyce served as a Chaplain with the New Zealand 3rd Army Division for a time in Vella Lavella, Solomon Islands, his familiarity with the area considered to be of use to the armed forces. He was also able to travel to meet church members on some of the other Western Province islands, and maintained contact with his Church colleagues in Auckland during these months. They reported he had visited the location of their former headquarters in the Munda area, on the island of New Georgia, including the site of their boat-shed, workshop and slip-way; but that all the vessels that had been left there were destroyed (NZMT, 22 January 1944: 5).

This account also seems to come from that time:

"On New Year's Eve, a native concert party, with Padre Voyce in charge, arrived at this camp, and in the afternoon, he conducted a thanksgiving service, which the natives of the village attended, bringing gifts of all kinds, such as mats, baskets, walking sticks, etc. That evening the concert party put on their show... when Padre Voyce announced that they would sing the "Hallellujah Chorus" I nearly fell off my seat with surprise... At the end of the concert, one of our lads acted as auctioneer and sold many of the articles brought down for the thanksgiving service. The bidding was quite spirited; an ordinary native mat sold for eighteen dollars, $£ 5$ 9s $6 \mathrm{~d}$ in New Zealand currency. Actually the mat was worth no more than about $9 \mathrm{~s} 6 \mathrm{~d}$. All the articles offered were sold for much more than their actual worth, but the lads were not thinking in terms of actual value. That was their way of contributing to the missionary work among the natives" (NZMT, 1 July 1944).

It seems Voyce continued to acquire objects during his time with the Army. Late in the year he wrote to Vic Fisher offering to sell a number of turtle shell pendants, cone shell pendants, tridcacna pendants, poata, shell currency and two pieces of 'native cloth' from 'the Vella Lavella, Kulambanga, Ranonga and Simbo areas of the New Georgia group of the Solomon Islands' (Voyce to Fisher, 4 December, 1944). Most were priced between one and five dollars, with annotated sterling conversion sums. Two separate 1944 purchases from Voyce are recorded; one of 273 items (accession no. 1944.14), the other of 63 items (accession no. 1944.75).

Voyce returned to New Zealand in early 1944; welcomed back at St Paul's, Remuera, on 27 February. In July of that year he gave a lecture titled 'The Native in the Pacific War Situation' at the Auckland Institute and Museum (New Zealand Herald, 20 July 1944). He also took advantage of the opportunity to research and write. In July, Methodist Times readers were informed that the Rev. Voyce had been granted three months leave on full pay to work on a book that would focus on 'our Mission work in the Solomons, but which will also include a geographical, historical and ethnological survey. After eighteen years' experience and close study of conditions on Bougainville and Buka and frequent contact with the British Solomons, Mr. Voyce's book should be authoritative and intensely interesting, especially to New Zealand and Australian Methodists' (NZMT, 1 July 1944: 2).

A.H. Voyce returned to Bougainville as soon as allowed - December 1945 (Luxton 1955: 197). His assessment of the situation at Kihili was, not surprisingly, depressing. As Japanese forces had occupied the area, it had been a target of the Allied offensive. He reported thousands of bomb craters full of stagnant water "and the Buin coast a litter of many hundreds of burnt-out Japanese trucks, motor-cars, tanks and other mechanical transport, gun posts, naval and anti-aircraft guns, planes and other things... Kihili... is a wilderness".

Beryl joined him a little later in the year, with a picnic set from the Ladies Auxiliary as part of her Auckland leaving gift. They and a number of other Methodist missionaries lived for some time on the west 
coast of the island at Cape Torokina, which had been the site of the first United States Marine amphibious landings in 1943. Voyce wrote in late 1946 of having sent a marquee down to colleagues who were building a station at Moisuru, near Kihili, which had access to a useful anchorage in Buin Bay (NZMT, 7 December 1946: 7). He also mentioned salvaging a two-engine barge and spoke longingly of a 'fine big refrigeration building' on the beach, both apparently left behind after the fighting.

The Voyces remained working in Bougainville for another decade, returning to live in New Zealand in 1958.

Arthur Henry Voyce died in Auckland in 1984. His funeral notice included the note: 'No flowers by request, but donations to the United Church, Bougainville, would be appreciated'. Beryl died nine years later in 1993.

\section{OTHER INTERESTS}

A.H. Voyce was also a shell collector and a keen philatelist. In the early 1930s he raised the subject of stamp collecting with Archey. Keen to obtain franked Solomon Islands stamps in good condition, he proposed posting a number of parcels to him at the Museum, from which Archey would carefully remove the stamps, with safe margins, and return them in his next letter to Voyce. A contributor to a postage stamp chat board in 2009 commented that 'For collectors of BSIP, a couple of Reverend A. H. Voyce covers are obligatory' (http:// www.stampboards.com/viewtopic.php?t=13132\&f=17).

In retirement he advertised for used WWII period envelopes from the Solomon Islands, and authored a number of Pacific postal history publications (Voyce 1966; Voyce 1971; Voyce 1974; Voyce 1981). A 1970s issue of Bougainville stamps (Voyce 1978) were illustrated with works from his own collection and, serendipitously, released on the Voyces' wedding anniversary.

He and his father worked together on Design Work as Shown on Bougainville Arrows and Spears (Voyce 1973). Deborah Waite's review astutely commented that the volume's primary value lay in 'the presentation of such a large quantity of weapons with geographic attributions and in the precise rendering of decorative details' (Waite 1978: 108). It also has a pleasing historic link. Voyce referenced the well-known Methodist missionary/collector George Brown's descriptions of Bougainville arrows (Brown 1908) and Melanesians and Polynesians (Brown 1910) in a letter, adding (Voyce to Scrivin, 31 October 1934), "I have a very varied collection of many scores of differing varieties of arrows ... some few with plain polished wooden points, and with decorated shafts, but the great majority being carved into very wonderful forms, many with holes of varying sizes through the heads, into which in times of fighting lighted grass or reeds were placed..., others again with forty and more reversely inserted barbs... others gaily decorated with coloured reeds".

Six years later he published Peacemakers: the story of David Pausu (Voyce 1979) which added to the documentation of Methodist church and mission history.

Voyce's name is also known in shell collecting circles and he published an article on Cox's cowrie (Voyce 1962).
As previously noted, he sold some species to aid mission fundraising. He also donated shells to the Auckland Museum at different times, the first with a group of corals and specimens of vegetable ivory, then collections of mollusca in later years (Annual Report of Auckland Institute and Museum 1931: 38; 1934: 45; 1935: 43).

He gave a number of butterflies to the Museum (Annual Report of Auckland Museum 1933: 19, 44) but there is little comment about their history and provenance. Newspaper accounts in 1930 and 1933 mention in passing that he showed tropical butterflies, shells and artefacts at talks given in New Zealand but do not elaborate.

\section{THE COLLECTION?}

The Revd Voyce was known in his lifetime to be a collector on an impressive scale. Douglas Oliver (1955) described him as an energetic collector of ethnographica. Thousands of artefacts left Bougainville at his instigation. A large but unknown number were possibly then-recently-made, for European purchase.

The Auckland Museum has 3452 artefacts purchased from A.H. Voyce. The molluscs and butterflies are additional. The Otago Museum has a similar number: there are more than 3500 object records linked to Voyce's name. As well as more than 1000 arrows, the collection includes adzes and axes, kapkap, bows, gourds, toys, pipes, women's clothing, belts, betel chewing equipment, baskets, bags and other containers, fish traps, combs, fishhooks, armlets, ceramic sherds, spears, ornaments, walking sticks, masks, clubs, a shield, bird snares, musical instruments, scrapers, wooden figures, barava fragments, sinkers, a pounder, tapa, and upi, molluscs and gastropods. More than 150 objects that Harry Beasley acquired from Voyce are now in the British Museum. In 1935 the Australian Museum bought 385 Bougainville - Buka artefacts from him: stone axes, body ornaments, bone implements, baskets, combs, aprons, spears and smoking pipes. Te Papa Tongarewa's Collections Online (https://collections.tepapa.govt.nz/ search/Voyce/results) shows 31 objects (including adze blades, armlets and armbands, belts, bags and biruka, combs and kapkap) and 12 specimens linked to A.H. Voyce. He also contributed some items to the Trinity Methodist Theological College Museum.

He collected, it seems, almost anything connected to the world he moved to in the 1920s. Some artefacts might have illustrated the different-ness of the foreign mission environment to a home audience. Others could bear witness to the changes Christianity had effected in the lives of the people among whom they lived. Well aware of this, Voyce described one particular neck ornament, asking 'Do you wonder why they brought this heirloom to me?' then answered, 'More and more as the years go by, are such things losing their value in the eyes of the people, no more, we hope, and believe, will tribal fighting take place in Siwai, for the Man of Galilee is making his influence felt in the cause of universal peace.' But it is his personal collection documenting minute variations in different object types; the multitude 
of items that reached various museums, the souvenirs and presents he arranged for visiting colleagues, which are more likely to be associated with him now. Personal collecting, and the enlistment of missionary assistance in the acquisition of cultural material and natural science specimens, by museums and other collectors, was almost commonplace in the early 20 th century. It had been so for decades when the Voyces went to Bougainville. Even so, the quantity of material he amassed is striking.

Where did it come from? Voyce had opportunities to collect in Bougainville that were available to few others in the first half of the 20th century. He was well known for walking great distances (Carter 1973: 181) during his first years on the island. He visited villages and other mission stations, relieved colleagues on furlough, attended Synod meetings in various locations, and travelled to larger centres for mail and supplies. Voyce visited commercial plantations on Bougainville in the course of his work and enjoyed the hospitality of their managers - a night's accommodation; a meal, a cup of tea or glass of chilled milk; offers of transport. He knew and sometimes travelled with men who had relatives or friends working on the plantations, and connections in other villages.

We have anecdotal hints at the relationship behind some pieces and though few, they indicate the breadth of his contacts and the contexts for his collection. The Auckland Museum collection includes some objects that came from named individuals (Figs 10 and 11).

He mentioned enquiring (successfully) for old stone implements when visiting a village to let them know the Mission could settle the teacher they wanted, there. He described a Thanksgiving service in which cash and curios both formed part of the collection (Voyce to Scrivin, 18 October 1934); the curios being sold (in that instance to staff) to add to the total. He mentioned going "into an inlet... leading eventually past a spot where the natives of that area meet at regular intervals to barter foods, etc. an old established native market" (Voyce to Scrivin, 30 July 1932). Although he physically unearthed some objects, he said that all the stone artefacts in his collection with the exception of perhaps 10 or 12 (which we found on clearing our station \& gardening)" had been purchased from local residents (Voyce to Archey, September 1933). He purchased and exchanged material with other collectors, for example Fig. 12. Dockets made out to A.H. Voyce from the Lutmis Store in Madang, record the sale of 14 Ramu axes for a total of $£ 2.15 .0$ and a wooden Sepik River figure for 3/6 in 1933.

Overall, one gains the impression that he was constantly open to possibilities. Did he fully understand the complexities of the gifts or exchanges he was part of? It is hard to know. We hear little of indigenous agency from him. He understood he had privileged access to the communities among whom he worked. His mission relationships meant he possessed, as he put it, 'a key of entry into almost every district'. He had some facility with the language himself and access to skilled interpreters. He mentions how eager villages are to have a teacher placed among them, and that the demand for injections and other medical services was great, but not the extent to which he considered that these were also part of the contexts in which his collecting took place.

One might also argue that his museum contacts effectively enabled Voyce to collect: financially and conceptually. One suspects he would have done so anyway, but they almost certainly augmented the scale. By purchasing material they freed up money for further acquisition. Provision of storage when material was on loan in the Auckland Museum - and research access after ownership changed hands - meant he was not burdened by those constraints and difficulties. Finally, they seem to have helped him to feel justified. When he introduced himself to WRB Oliver by saying he collected for several well-known museums, he was essentially offering credentials and claiming a collegial standing.

Voyce also actively increased the range of material culture items made (at least for sale; perhaps not for local use) in the areas in which he lived. He and Beryl introduced basket making to the Siwai area through the Tonu mission station. Beyond the usual means of church circulation, these were sold through a Bougainville trader and overtures were made to an Auckland outlet. When at Teop, he said they had "taught a lot of varying handicrafts, e.g. shells strung on strings as necklaces... sold ... at $1 \mathrm{~s}$ per string, occasional tables, walking sticks of very old coconut wood, some inlaid with shell, others carved tops, others with ivory nut tops and others just plain polished sticks, serviette rings of plaited pandanus and wild black banana fibres etc, etc," (Voyce to Scrivin, 18 October 1934). Parallels between this and the list of items sold for fundraising purposes (NZMT, 14 October 1933: 10) indicate that the material advertised for sale at his meetings in New Zealand, and at the 1944 concert party described above, were largely of contemporary manufacture. How much of the material sold to museums or circulated through other transactions was of this ilk is unclear, and possibly not well documented. Geographical provenances are attached to a large number of Voyce collection items, but that is not of course an indication of age. There are, for example, quantities of seemingly little-worn fibre items.

The scientific corollaries of collecting appealed to Voyce. Aware that it would enhance the interest and research value of objects he amassed, he noted local language names, recorded localities, sought to identify variations of a form or design. He developed an interest in folklore and legends, and joined the Polynesian Society. Madden, at the Cranmore Museum (possibly at Beasley's behest), organised Voyce's nomination as a Fellow of the Royal Anthropological Institute, with local correspondent status.

During periods of leave he spent time working with material he had deposited in the museum. Planning to publish, he asked museum staff for sketches, diagrams, photographs, measurements, weights and geological determinations. Classificatory systems appealed. As Gardner (2006) noted for his 19th century predecessors, morphology and geographical location; presence or absence interested him. He told Vic Fisher how helpful for his formulation of tool types he had found it to be able to see all the relevant material together in one place. 


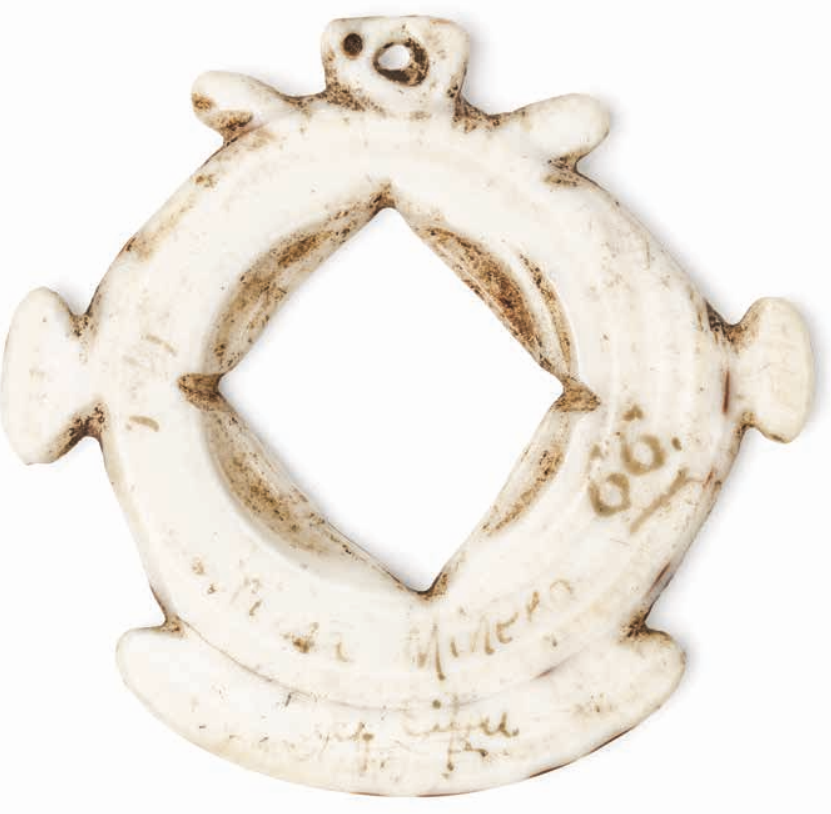

Figure 10. 'Kesi, shell breast ornament. from Chief Sipiu.' January, 1931. Sirima, Mihiro, Siwai District, Bougainville. Auckland War Memorial Museum. 1934.145. 20189.

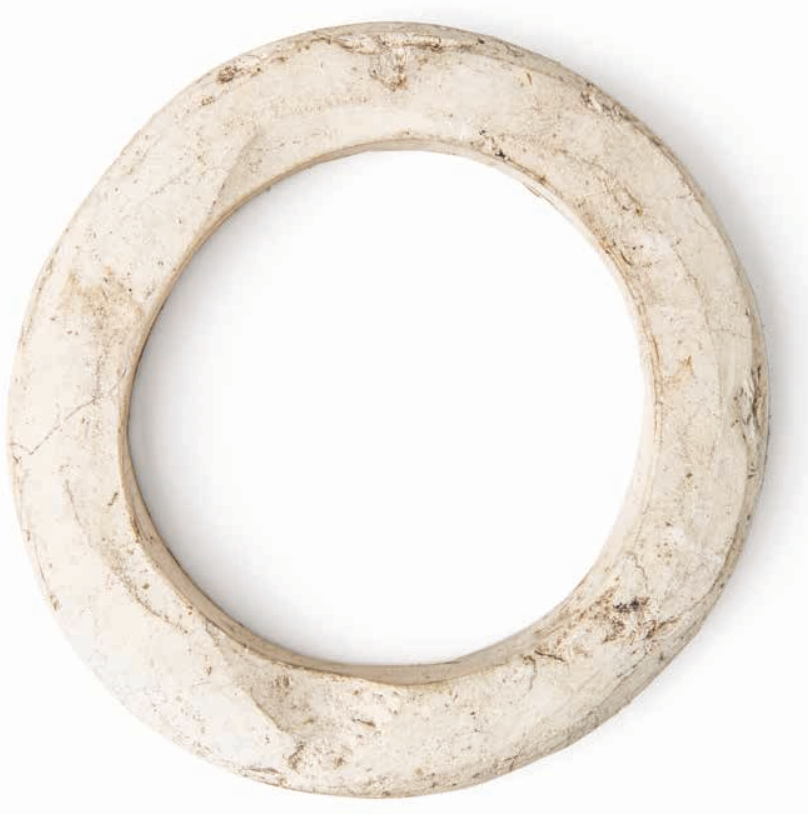

Figure 12. Poata, shell ring. Dug up at Kindu by Rove, December 1930. Kindu, Roviana, New Georgia. Auckland War Memorial Museum. 1934.145. 20204.

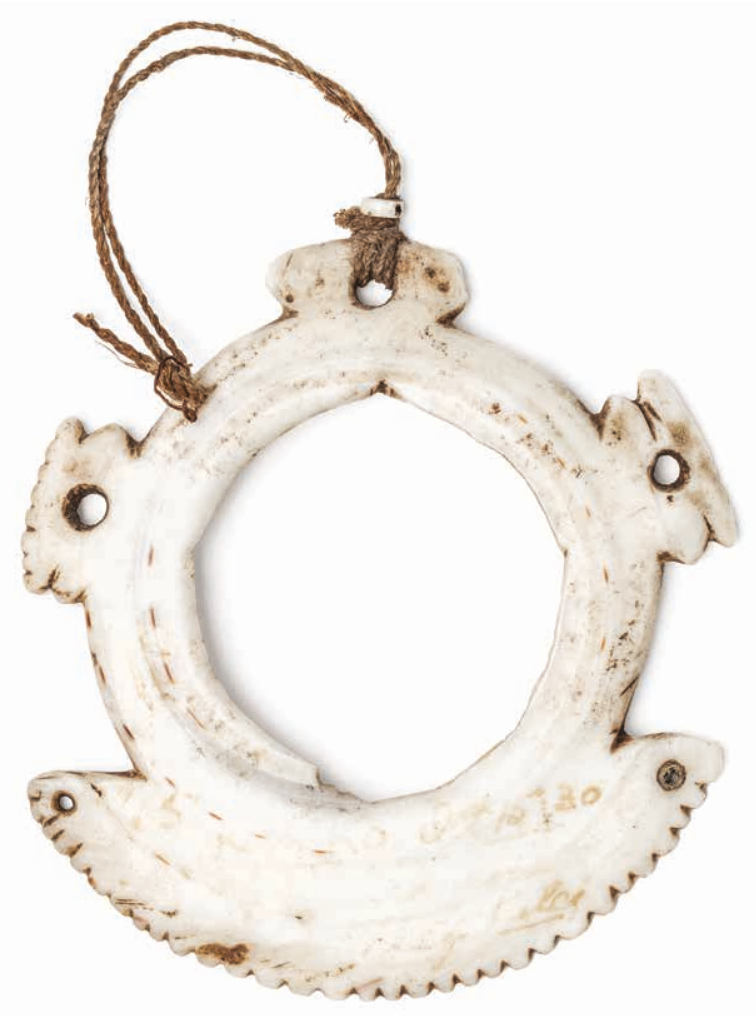

Figure 11. 'Kesi, shell breast ornament from Chief Putei.' October, 1930. Kahiko, Siwai District, Bougainville. Auckland War Memorial Museum. 1934.145. 20194.

'Remember how our backs used to ache when we were working on the stone implements?' he asked. Skinner encouraged his interest in writing. He lent him books by Douglas Kennedy, and Gladys Reichard (1933), and singled out Te Rangi Hiroa's Samoan Material Culture (Buck, 1930) as a model.

Despite all this, Voyce's publications are primarily philatelic. The National Library of Australia holds copies of school exercises (Voyce 1931) and hymns that Voyce translated into Motuna (Voyce 1932). The Auckland Museum Library holds a manuscript copy of a draft paper on wooden drums from Bougainville (Voyce ms). H.D. Skinner expressed confidence that it would be of interest to the JPS but encouraged him to consider making the varied articles he was contemplating, chapters in a single book (Skinner to Voyce, 18 December 1933). It is unclear whether the manuscript Voyce was working on in 1944 stemmed from that; if it was one of those he did publish; or if it was uncompleted.

As Lucie Carreau (2010) perceptively wrote when discussing Harry Beasley, it is often unclear when a collection starts or gains formal recognition. As with Beasley's, the inception of the Voyce collection is vague. Indeed, can every item that passed through his ownership be considered part of his collection? Its full extent is ambiguous for a number of reasons including the multiplicity of people whose own collecting he facilitated. While conventions vary between institutions, 


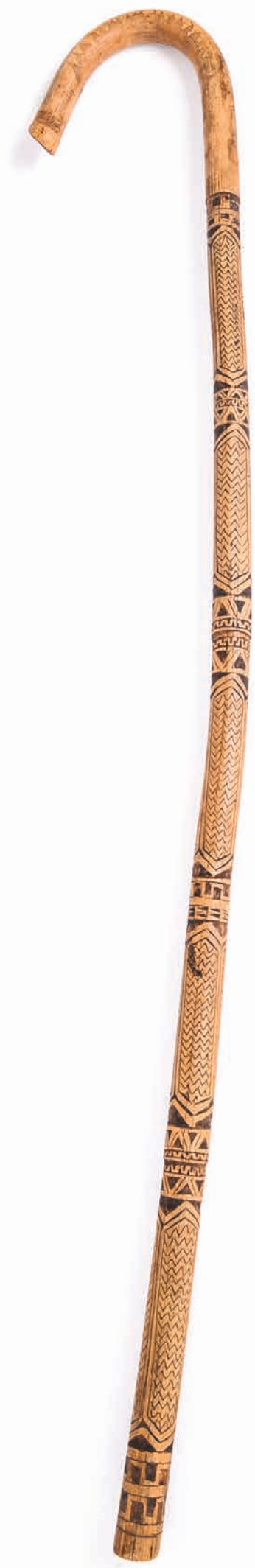

Figure 13. Walking stick. Otago Museum, Dunedin. D39.1891. at the Auckland Museum the appropriate courtesies of acknowledgment meant that at the time of acquisition, Voyce was less publically reported in connection with the collection than were Sir William Goodfellow or E. Earle Vaile, the donors.

A question to add is when does a collection end? Voyce's first sale to the Auckland Museum seemed to mark a finite group of material with some personal meaning to him. Yet once the transaction was complete, acquisition started anew, or continued. As each group was parted with others seemed to come into view.

To what extent can his collection be said to represent a way of life in Bougainville? We might wish we knew more of the cultural context for the objects he acquired, and more details of the relationships and transactions that took place between Voyce and the original owners. What role did he see for the mass of material culture that he helped to leave Bougainville, play in New Zealand, Australian and European museums?

The Voyce collection also invites conjecture about the role of these objects in his own identity, to the world of the museum associates with whom he was in contact for a decade or more; and their impact on the public who have seen and thought about them since they left Melanesia.

\section{ACKNOWLEDGEMENTS}

Grateful thanks to Louise Furey and to Kolokesa Māhina-Tuai, also to Fuli Pereira, and Zoe Richardson, all of Tamaki Paenga Hira Auckland War Memorial Museum; Logan Mecalfe, Australian Museum; Cynthia McKenzie, Methodist Church Archives; Jennifer Twist, Te Papa Tongarewa Museum of New Zealand; and Christopher Pugsley.

\section{REFERENCES}

Anonymous, 1936. Minutes and Proceedings of the Fifth Science Congress of the Royal Society of New Zealand. Transactions and Proceedings of the Royal Society of New Zealand 36: 451-6

Annual Report of the Auckland Institute and Museum for 1930-31. Auckland.

Annual Report of the Auckland Institute and Museum for 1932-33. Auckland.

Annual Report of the Auckland Institute and Museum for 1933-34. Auckland.

Annual Report of the Auckland Institute and Museum for 1934-35. Auckland.

Annual Report of the Auckland Institute and Museum for 1939-40. Auckland.

Annual Report of the Auckland Institute and Museum 1940-41. Auckland.

Bateson, Gregory, 1936. Naven: A Survey of the Problems suggested by a Composite Picture of the Culture of a New Guinea Tribe drawn from Three Points of View. Cambridge University Press.

Beasley, H.G., 1928. Pacific Island Records: Fish Hooks. London: Seeley, Service \& Co.

Blackwood, Beatrice, 1935. Both Sides of Buka Passage. Oxford: Clarendon Press. 
Brown, George, 1908. George Brown, D.D. Pioneermissionary and explorer, an autobiography; a narrative of forty-eight years' residence and travel in Samoa, New Britain, New Ireland, New Guinea and the Solomon Islands. London: Hodder and Stoughton.

Brown, George, 1910. Melanesians and Polynesians: their life-histories described and compared. London: Macmillan \& Co.

Buck, Peter Henry, 1930. Samoan Material Culture. Honolulu: Bernice Pauahi Bishop Museum.

Carreau, L., 2010 'Becoming 'Professional': From the Beasley Collection to the Cranmore Ethnographical Museum. Journal of Museum Ethnography 23: 41-55. Accessed 10 July 2018, Stable URL: http:// www.jstor.org/stable/41416854

Carter, George, 1973. A Family Affair. Auckland: Institute Press.

Gardner, Helen, 2006. Gathering for God: George Brown in Oceania. Dunedin: Otago University Press.

Guppy, H.B., 1887. The Solomon Islands and Their Natives. London: Swan Sonnenschein, Lowrey \& Co.

Ivens, Walter, 1927. Melanesians of the South-east Solomon Islands. London: K. Paul, Trench, Trubner.

Luxton, C.T.J., 1955. Isles of Solomon. A Tale of Missionary Adventure. Auckland: Methodist Foreign Missionary Society of New Zealand.

Meyer, A.B. and R. Parkinson, 1900. Album of Papua types II. Dresden: Stengel \& Company.

Oliver, D., 1955. A Solomon Island Society. Harvard University Press.

Oliver, D., 1973. Bougainville a personal history. Melbourne University Press.

Reichard, Gladys, 1933. Melanesian Design, a study of style in wood and tortoiseshell carving. New York, Columbia University Press.

South Australian Museum and H.M. Hale, 1956. The First Hundred Years of the [South Australian] Museum 1856-1956. Adelaide.

Voyce, A.H., [1931] Solomon Islands school exercises, English-Motuna. Wellington: Wright and Carman Printers.

Voyce, A.H., 1932. [Hymns]. Kieta Bougainville: Methodist Mission.

Voyce, A.H., 1962. Hunting Cypraea coxeni in the Solomon Islands. The Cowrie 1 (4): 56-8.
Voyce, A.H., 1966. The Postal History of Barakoma Airfield. Melbourne: Hawthorn Press.

Voyce, A.H., 1971. New Zealand Registration Markings. Auckland: Postal History Society of New Zealand.

Voyce, A.H., 1973. Design Work as Shown on Bougainville Arrows and Spears. Rabaul: Trinity Press.

Voyce, A.H., 1974. Bougainville Police Runner Mails. Masterton: R. Startup for the Postal History Society of New Zealand.

Voyce, A.H., 1978. Bougainville Art: the planning of a set of new stamps. Coromandel: Ponwinkle Publications.

Voyce, A.H., 1979. Peacemakers: the story of David Pausu and the United Church of South Bougainville. Auckland, Wesley Historical Society.

Voyce, A.H., 1981. A Place in the Sun. Coromandel: Ponwinkle Publications.

Voyce, A.H. The wooden drums and drumming of the Motuna people, South-western Bougainville Island, Northern Solomons, Mandated Territory of New Guinea. Auckland War Memorial Museum MS-632.

Waite, Deborah B., 1978. Review: Voyce, H. M. Design Work as shown on Bouganville Arrows and Spears. Pacific Studies 2(1): 107-8.

Unpublished sources

Correspondence between A.H. Voyce and staff of the Auckland Museum is held at the Auckland Museum Library:

Between 1931 and 1935 (incl.), correspondence between Archey and Voyce, between Fisher and Voyce, and between Voyce and the Auckland Museum, is held at Auckland War Memorial Museum MUS-95-43-20.

Between 1938 and 1945 (incl), correspondence between Archey and Voyce, between Fisher and Voyce, between Turbott and Voyce, and between Voyce and the Auckland Museum, is held at Auckland War Memorial Museum MUS-95-43-21

Correspondence between Voyce and Scrivin is held at Alexander Turnbull Library Micro-MS-Coll-08-0935

Correspondence between Voyce and Oliver is held at Museum of New Zealand Te Papa Tongarewa: MU000002-064-0

Moira White, Otago Museum, Dunedin. Moira.White@otagomuseum.nz 



\title{
The plants of Waya Island, Fiji
}

\author{
Rhys O. Gardner Auckland War Memorial Museum
}

\begin{abstract}
An annotated species-list is given for Waya Island (Yasawa Is. Group, Fiji). It contains 38 ferns and lycophytes, 1 cycad, 55 monocotyledons, and 224 dicotyledons. Nearly all these 318 species are indigenous to Fiji or are likely to be ancient (pre-European) introductions. Except for six species, post-European introductions (weeds and cultivated species) have not been included.

Two species are endemic to Waya: Embelia deivanuae (Myrsinaceae) and Psychotria volii (Rubiaceae). Five are rare in Fiji: Guettarda wayaensis (Rubiaceae), Mollugo pentaphylla (Molluginaceae), Ormocarpum orientale (Leguminosae), Polystichum pilosum (Dryopteridaceae), and Prosaptia vomaensis (Polypodiaceae). Another two Fijian rarities, Euphorbia plumerioides (Euphorbiaceae) and Sarcolobus stenophyllus (Asclepiadaceae), were found on Waya in 1937 but have not been seen since.

Waya's taller native vegetation is situated mostly on rugged rocky topography and is dominated by members of Leguminosae (Cynometra, Kingiodendron, Maniltoa), Sapindaceae and Sapotaceae. In Fiji at large such "dry zone" cover has been greatly reduced by continual fires, so Waya's remnants, though small and discontinous, have substantial biodiversity value.
\end{abstract}

\section{Keywords}

Waya Island; Yasawa Islands; Fiji archipelago; higher-plant species; dry-zone forest.

\section{INTRODUCTION}

This account of the higher-plants found on the small Fijian island of Waya mainly concerns species native to Fiji, but a number of post-European introductions have been included too - in total 318 species are treated. It is largely based on specimens collected by Harold St John in 1937 and cited in A. C. Smith's Flora Vitiensis Nova, and on collections made by the author in 1991, 1992 and 2017. St John seems to have been the first botanist to visit Waya - although both the U.S. Exploring Expedition in 1840 , and Berthold Seemann in 1860, made collections from a range of Fiji's islands they did not make landfall in the Yasawas. Since St John's time, this group of islands has been collected from only infrequently (Smith 1979: 76). I hope to show that this neglect is undeserved.

I have written twice already on Wayan botany: on my most noteworthy finds (Gardner 1997), and on plantnames in the Wayan ("West Fijian") language (Gardner $\&$ Pawley 2006). The latter article makes no mention of those indigenous species - mainly the less common ones and those of no use to humans - that lack a Wayan name.

\section{THE SETTING}

Waya is located at the southern end of the Yasawa Islands chain, $50 \mathrm{~km}$ off the northwestern coast of Fiji's largest island, Viti Levu (Fig. 1). It is a "high" (volcanic) island, irregularly circular in outline, c. $7 \mathrm{~km}$ in diameter and 2100 ha. in extent. Its rugged topography, deriving from andesitic flows, agglomerates and tuff, reaches 510 $\mathrm{m}$ (1673 feet) at the peak of Vatunareba in the southeast, overlooking the bay of Yalobi. The highest point, of 561 $\mathrm{m}$ (1841 feet), is reached in the northeast by the less dramatic peak of Uluiwaya.

Yalobi (to early Europeans, Alacrity Bay) on the southern coast is the largest of the island's several, reef-fringed bays. In Yalobi village, and in the island's three other coastal villages, Nalauwaki, Waya Levu, Natawa, there live c. 1200 people, their lifestyle based on fishing and gardening (cassava, bananas, yams), together with income from cruise-ship visits, backpacker tourism, and off-island work, e.g., in Fiji's tourist resorts (Waya has just one of these).

Human occupation of Waya goes back 2,500 years or more (Hunt et al. 1999), so it is unlikely that any of the existing taller vegetation can be thought of as "original". The slopes above the gardened valleys are mainly of induced grassland or scrub, with forest only in those areas too steep or too rocky to cultivate and where fire cannot get to. There are considerable areas of bare or scrubby rocky ground on Vatunareba.

The central part of the island consists of broken topography between the island's two high- points. Relatively well-forested, it is the watershed for a number of small streams, but in its more fertile places trees are continually being felled, often for the cultivation of agona (the kava plant, Piper methystichum). 


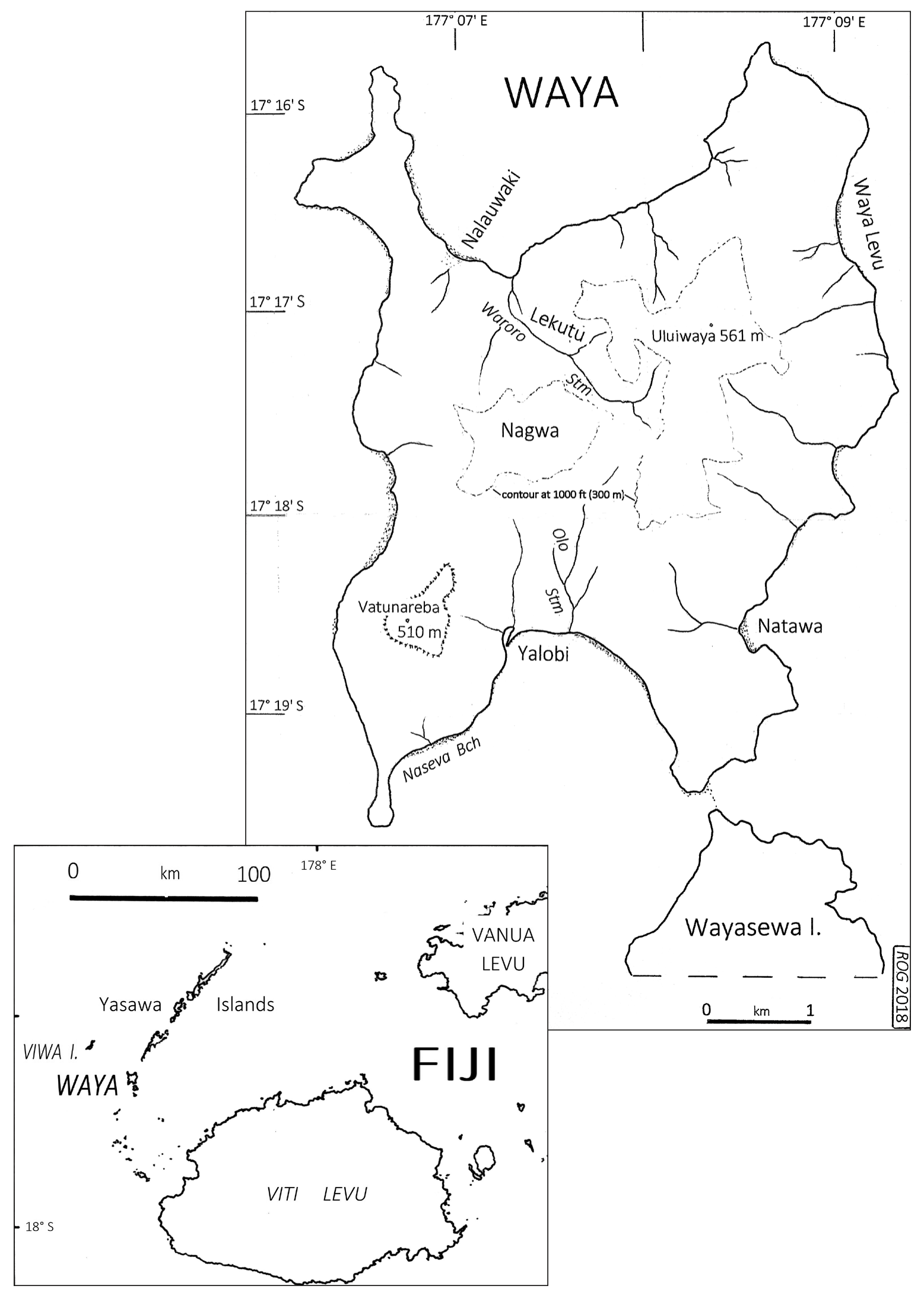

Figure 1. Waya Island. Based on the chart "Yasawa Islands, Fiji. Sheet 1: Waya Group", surveyed by A. H. Pickmere. Alexander Turnbull Library, Wellington. [Privately published 1973; reproduced here with the permission of the copyright holder Janet M. Watkins, Auckland]. Note: the location of "Lekutu" is approximate only. 
Waya has a climate similar to that of the eastern (leeward) coast of Viti Levu, with a distinctly dry, cool season during the middle part of the year (Derrick (1957: 108; Twyford \& Wright 1965: 76). This dryness is intensified by the often very shallow character of its predominantly steepland soils (Twyford \& Wright 1965: 491). The island then has special ecological and conservation interest, with "dry zone forest" now greatly depleted not just on the larger Fijian islands but in the New Caledonia-Fiji-Tonga region at large (MuellerDombois \& Fosberg 1997; Gillespie \& Jaffré 2003; Keppel \& Tuiwawa 2007).

Most of Waya's coastal and low- to mid-altitude forest has gone, but the woody plants that remain can be taken to indicate what "dry zone forest" here was like:

a) a low presence of "moist rainforest" taxa, e.g., absence of Arecaceae, Elaeocarpaceae and Podocarpaceae, only one member of Hymenophyllaceae (Trichomanes atrovirens), only one member of Lauraceae (Litsea vitiana), absence of Elatostema (and the wide-ranging Procris pedunculata is present but rare), and just one species each of Cyrtandra and Medinilla (both rare on Waya);

b) an abundance of species belonging to Anacardiaceae, Ebenaceae, Sapindaceae and Sapotaceae; abundance of Geissois ternata (Cunoniaceae); local dominance of legume trees, that is, species of Cynometra, Kingiodendron, Maniltoa and Serianthes - cf. the dry Maniltoa-Pleiogynium forest of the Tonga island of Eua (Mueller-Dombois \& Fosberg 1997: 353);

c) a predominance of drought-resistant species in the regrowth communities: Dodonaea viscosa, Ficus barclayana, Mallotus tiliifolius, Melochia degeneriana and Parasponia andersonii, these small trees together with semi-scandent "cast-iron" shrubs such as Rhamnella vitiensis, Smythea lanceata and Ventilago vitiensis (all Rhamnaceae), and Celastrus richii (Celastraceae).

Although Waya's forest and scrub is now very discontinuous it is still "natural" in that the most aggressively weedy trees of other dry parts of Fiji notably the legumes Adenanthera pavonina, Albizia saman, and Leucaena leucocephala, are relatively restricted in extent.

Waya's ecological values are also greatly enhanced by the absence of that Fijian pest the small Asian mongoose, Herpestes javanicus. Consequently, smaller lizards are abundant, and also, Fiji's largest and most endangered lizard, the Fijian crested iguana (Brachylophus vitiensis), is still regularly sighted. Unfortunately for its indigenous plants though the island is home to a fair number of goats, their introduction dating back to the late 1940 s or early '50s (A. Pawley pers. comm.).

\section{SCOPE AND STYLE}

No keys or descriptions of the families and genera represented in Waya's flora are given here. However, scans of herbarium specimens of some of the more notable species (mostly those endemic to Fiji, or species indigenous to Fiji but uncommon there) can be found on the web-site of the Auckland War Memorial Museum (http://www.aucklandmuseum.com/collections-research/ collections/search). All are my own Wayan collections, housed in the herbarium of this museum.

In the main text below the species are arranged alphabetically by family, within the following sequence: 38 ferns and lycophytes (Lycopodiella, Psilotum and Selaginella); 1 gymnosperm (a species of Cycas); 55 monocotyledons; 224 dicotyledons. A concise listing is given in Appendix 1.

A number of the species treated are probably not indigenous to Fiji. Most of these are likely to have been introduced in pre-European times, being food-plants or weeds associated with the peopling of the Pacific Ocean region. Six species likely to be modern introductions have been included, either because they are so conspicuous in the Wayan landscape, e.g., the grassland-dominant Cenchrus polystachios, or because they represent a new distribution record, e.g., Adiantum trapeziforme. Also, coastal species not so far known from Waya but occurring (or likely to occur) $27 \mathrm{~km}$ westwards on the atoll of Viwa I. have been included.

Two species appear to be endemic to Waya: Embelia deivanuae (Myrsinaceae) and Psychotria volii (Rubiaceae). Two species of wide distribution westwards of Fiji, Carex brunnea and Rinorea benghalensis, are currently known in the Fiji archipelago only from Waya. Two or possibly three Wayan species appear to be rare Fijian endemics: Guettarda wayaensis, Polystichum pilosum and possibly Prosaptia vomaensis. The legume tree Serianthes vitiensis, rare on Waya, is known otherwise by only two or three old collections from Vanua Levu. St John collected two rare Fijian plants I was unable to find: the widespread Euphorbia plumerioides, and the Fijian endemic Sarcolobus stenophyllus (Asclepiadaceae).

\section{SCIENTIFIC NAMES}

Names for the ferns and lycophytes, including family ones, have been updated from those of Brownlie (1977), using mainly the checklist of Brownsey \& Perrie (2011). For the flowering-plant genera and families Flora Vitiensis Nova (hereafter, FVN) has largely been adhered to, in order to assist reference to that comprehensive work's keys etc. However, three updated placings have been made: Cordyline is transferred into Asparagaceae, Dianella into Xanthorrhoeaceae, and all legumes into Leguminosae. Also, because FVN's family-level classification is now seriously out of date, reference is sometimes made to the latest scheme ("APG IV") of the Angiosperm Phylogeny Group (2016), e.g., "Casearia FLACOURTIACEAE (APG IV Salicaceae)". Where names at specific or generic level have been updated, the ones used by Brownlie (1977) or FVN are given using the phrase "Formerly known as X". 


\section{WAYAN PLANT NAMES}

The language of Waya belongs to the Western Fijian Language grouping (Geraghty 1983: 268). The Wayan plant-names offered in the present work do not include the obsolete ones (cited as such by Gardner \& Pawley 2006). These names, recorded by St John but not confirmed by me in 1991/2, have been included here in the citation of St John's specimens, with modern spelling added if necessary.

\section{THE SPECIMENS}

Except for a relatively small number of entries (mainly sight-records of the writer) this work is specimen-based. Almost all the specimens were collected by St John or me, but a few others have been added from the citations of FVN. For the identification of St John's specimens reliance has been placed on Brownlie (1977), FVN, and modern revisions. Some of St John's Wayan collections at US can be viewed at that institution's online database.

Collection details for St John and me are as follows (modern spellings in brackets):

\section{St John}

Collection numbers 18005-18173, made 15-22 July 1937; specimens at BISH in the first instance, with some duplicates at US and (at least of some ferns) at SUVA. The numbers (which include several bryophytes) and their localities are:

18005-18012, 18030, 18059-18060, 18089-18097, 18171-18173 Yalobi

18013-18029 Olo Creek, N of Yalobi

18031-18058 Naruarua Gulch, W side of Batinareba [Vatunareba]

18061-18067 woods along Waroro Creek

18068-18088 woods along Wailevu Creek 18098-18120, 18153-18170 Nagua [Nagwa]

18121-18130 woods along Olo Creek, N of Yalobi

18131-18152 Nakawa Gulch, W side of Batinareba

[Vatunareba]

St John's obsolete plant-names are cited as written in his notebook (BISH), as are the names of his localities (which are cited only where I did not rediscover the species). The exact location of St John's two gullies ("gulches"), on the west side of Vatunareba, and his "Wailevu Creek", seem to be unknown to the Wayan people of today.

\section{R.O. Gardner}

My specimens, which were obtained from numerous localities on Waya, are numbered 6249-6541 (27 Oct to 15 Nov 1991), 6654-6890 (12 July to 16 August 1992), and 11291-11344 (2-11 June 2017). Their label-notes on habitat etc., have sometimes been rewritten in the present work, in the interest of brevity and clarity. A first set of these collections is at AK; others are at BISH, CHR, SUVA and US.

\section{THE ENTRIES}

If a species is endemic to Fiji this is stated. For distribution within the Fijian archipelago the data offered here is just a summary of that in Brownlie (1977) and FVN. These works were based on a thorough knowledge of the Fijian collections gathered up to that time, so they should still be adequate, at least for comparative and conservation purposes. For abundance on Waya itself some indication is often given in the specimen-notes.

All St John specimens cited in FVN, but only the most informative of the my own have been included in the species-entries.

In the entries the citing of synonyms and references has been kept to a minimum. To find more about a particular Wayan fern or lycophyte's taxonomic history, and relevant keys and descriptions, see Brownlie (1977), Orchard \& McCarthy (1998), Nakamura \& Matsumoto (2008), and Chen et al. (2017). For flowering plants the best source of such data is FVN, but it is not yet available as an e-book. However, the two classic accounts of Fiji's flowering plants, Asa Gray's (1854) U.S. Exploring Expedition volume (only partly about Fiji) and Berthold Seemann's Flora Vitiensis (186573), are available at free-access Web sites like Botanicus and Biodiversity Heritage Library. When referring to Gray and Seemann I have noted page numbers, which will make it unnecessary to first consult FVN or other secondary sources.

Gray is still worth reading, for his expressive descriptions. Seemann's descriptions are in Latin but his long asides on Fijian ethnobotany and history, e.g., on Cocos, Excoecaria, Ficus obliqua, Piper methysticum, Santalum and Tacca, are in English. Both works, and also the U.S. Exploring Expedition volume on ferns (Brackenridge 1855) contain superb illustrations of Fijian plants, and these have been noted in the species-entries.

\section{SIGNS AND ABBREVIATIONS}

* Superscript before species' name indicates a likely introduction in post-European times.

$\varnothing \quad$ diameter

dbh diameter breast height (of a tree trunk)

E east(ern)

flr(s) flower(s)

Illn illustration

infl., infls. inflorescence(s)

1.s. longitudinal section

occ. occasionally

NW north-west(ern), SE south-east(ern), etc.

t.s. transverse [cross-]section

us. usually

FV Flora Vitiensis [B. Seemann 1865-73]

FVN Flora Vitiensis Nova [A.C. Smith, 1979-91]

USEE 15, Atlas U.S. Exploring Expedition Vol. 15, Atlas [A. Gray, 1856]

USEE 16, Atlas U.S. Exploring Expedition Vol. 16, Atlas [W. Brackenridge, 1855] 
AK Botany Department, Auckland War Memorial Museum, Auckland, New Zealand

BISH Herbarium Pacificum, Bishop Museum, Honolulu, Hawaii

CHR Allan Herbarium, Landcare Research, Lincoln, New Zealand.

DA Department of Agriculture, Fiji (herbarium collection series; first set at SUVA).

SUVA South Pacific Regional Herbarium, University of the South Pacific, Suva, Fiji

TNS National Museum of Nature and Science, Tsukuba, Japan

US United States National Herbarium (Smithsonian Institution), Washington D.C., U.S.A.

\section{FLORA, PART 1: FERNS, LYCOPHYTES, CYCAD}

\subsection{ASPLENIACEAE}

Asplenium amboinense Willd.

Abundant in Fiji's forests. ROG 6796, E side of peaks above Waya Levu, occ. in mesic places in forest. Illn: USEE 16, Atlas pl. 19 fig. 2.

Asplenium polyodon G. Forst.

In Fiji most abundant in higher-altitude forests of the larger islands. St John 18033, "tokalo". Illn: USEE 16, Atlas pl. 22 fig. 1, as A. falcatum var. attenuatum.

\subsection{BLECHNACEAE}

Blechnum orientale $\mathrm{L}$.

Widespread in Fiji's forests. St John 18061, "ndondobalawa".

\subsection{CYATHEACEAE}

Cyathea lunulata (G. Forst.) Copel. balabala Widespread in Fiji, often abundant. St John 18098, “mbalambala". ROG 6336, -7, near Nagwa, to $7 \mathrm{~m}$ tall $15 \mathrm{~cm} \mathrm{dbh}$, in damp gullies in secondary forest. Illn: USEE 16, Atlas pl. 39, as "Alsophila lunulata R.Br. ?". Holttum (1964:267) considered that this plate represents the Fijian plant, i.e., the endemic subspecies C. lunulata subspecies vitiensis (Carr.) Holttum.

\subsection{DAVALLIACEAE}

\section{Davallia heterophylla Sm.}

Widespread in Fiji's lowland forests. St John 18157, "kara". Formerly known as Humata heterophylla.

Davallia solida (G. Forst.) Sw.

Widespread on Fiji's dry-zone coasts, including those of the smaller islands. ROG 6438, towards the peaks $\mathrm{N}$ of Yalobi, on shady rock cliffs away from goats.

\subsection{DENNSTAEDTIACEAE}

\section{Microlepia speluncae (L.) T. Moore}

Rather local in Fiji (Waya, the three largest islands, and Ovalau). ROG 6514, slope NW of Vatunareba, common in open bouldery forest.

Pteridium esculentum (G. Forst.) Cockayne mata Abundant locally in the drier parts of Fiji's two largest islands. No specimen known from Waya, but species presence recorded on label of ROG 6536 (Pteris vittata).

\subsection{DICKSONIACEAE}

\section{Calochlaena straminea (Labill.)}

M.D. Turner \& R.A. White balabala leke Widespread in Fiji, in open mesic forest sites. St John 18064. ROG 6341, Nagwa, uncommon in shady secondary forest. Formerly known as Culcita straminea. Illn: USEE 16, Atlas pl. 38 fig. 2, as Dicksonia torreyana.

\subsection{DRYOPTERIDACEAE}

Polystichum pilosum Copel.

Endemic to Fiji, rare; in open forest or scrub, known just from Waya and two dry montane localities (Ba, Viti Levu; Macuata, Vanua Levu). ROG 6785, towards Vatunareba summit, occ. in uppermost gully forest.

\subsection{GLEICHENIACEAE}

Dicranopteris linearis (Burm.f.) Underw. mata Common in Fiji's dry regions, often with Pteridium esculentum. St John 18071, "kavindi".

\subsection{HYMENOPHYLLACEAE}

Trichomanes atrovirens (C. Presl) Kunze Widespread and abundant in Fiji's forests, St John 18122, "rhausongiri". ROG 6863, E of Koroimatalevu peak (high point S of Lekutu), local on clay banks of stream in shady forest. Formerly known as Trichomanes boryanum.

\subsection{LOMARIOPSIDACEAE}

Nephrolepis hirsutula (G. Forst.) C. Presl digi Abundant in Fiji. ROG 6377, Yalobi to Nalauwaki track, occ. at forest edges and straggling among Miscanthus. In Gardner \& Pawley (2006) this collection was identified as $N$. biserrata (Sw.) Schott. I now think it agrees better with $N$. hirsutula, having dark-centred appressed scales on the base of the stipe, and rachisscales that are red-brown, acuminate and strongly dentate distally (Hovenkamp \& Miyamoto 2005). 


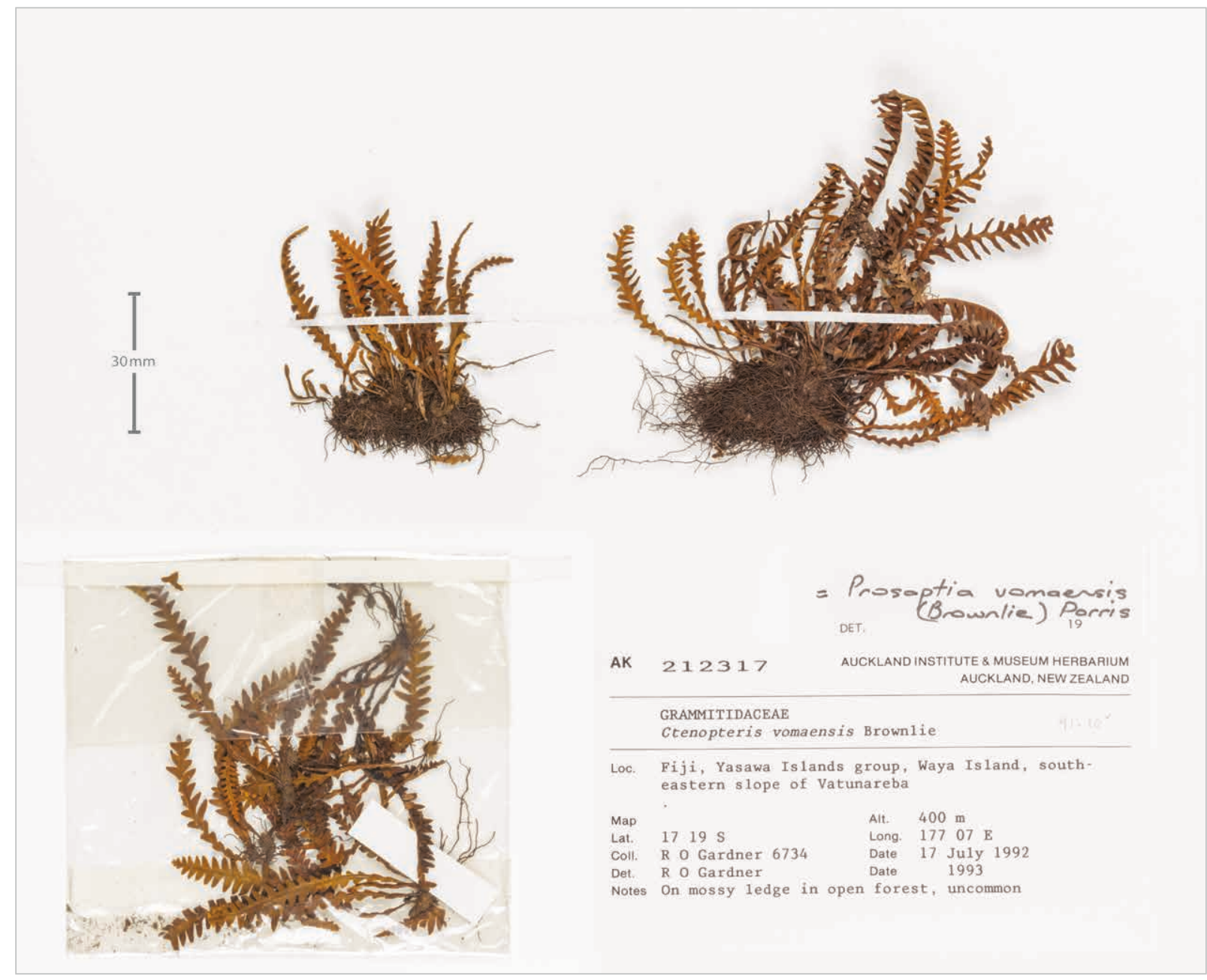

Figure 2. Prosaptia vomaensis, AK212317. (c) Auckland Museum CC BY.

\subsection{LYCOPODIACEAE}

\section{Lycopodiella cernua (L.) Pic.Serm.}

Abundant in Fiji. St John 18068, "o ranaranga". Formerly known as Lycopodium cernuum.

\subsection{LYGODIACEAE}

\section{Lygodium reticulatum Schkuhr}

vere lumuka

In Fiji widespread on forest margins and in secondary forest. ROG 6251, Yalobi, common in dryish scrub. Wrongly cited as L. articulatum by Gardner \& Pawley (2006: 107).

\subsection{MARATTIACEAE}

Angiopteris evecta (G. Forst.) Hoffm.

bāwale

Widespread and abundant in Fiji's wetter forests. St John 18114. ROG 6489, peaks W above Nagwa, in dense forest away from goats, uncommon.

\subsection{POLYPODIACEAE}

Drynaria rigidula (Sw.) Bedd.

sova ni gwata

Widespread in Fiji, especially in open forest. St John 18046, "temba". ROG 6456, slope W of Yalobi, perching on older trees.

\section{Microsorum grossum (Langsd. \& Fisch.)}

S.B. Andrews

vativati

Widespread in Fiji's dry open forests. ROG 6320, gardens in valley NW of Yalobi, edge of relic forest among boulders. Formerly known as Phymatosorus grossus.

\section{Prosaptia vomaensis (Brownlie) Parris}

Perhaps endemic to Fiji, in rocky forest (Waya, Viti Levu) at mid-altitude. ROG 6734, SE slopes of Vatunareba, on mossy ledge in open forest, uncommon. Formerly known as Ctenopteris vomaensis. Recorded from Vanuatu (Nakamura \& Matsumoto 2008: 249) but a voucher cannot be located (A. Ebihara of TNS, pers. comm. March 2015). Fig. 2. 
Pyrrosia lanceolata (L.) Farw.

tuāida

Widespread in drier forests of Fiji. St John 18141, "komokomo". ROG 6688, SE slopes of Vatunareba, uncommon epiphyte in gully forest. Formerly known as Pyrrosia adnascens.

\subsection{PSILOTACEAE}

Psilotum nudum (L.) P. Beauv. velau kai Widespread in Fiji. ROG 6665, above Olo stream, a few plants on ledge of shaded rock face, seemingly uncommon on the island.

\subsection{PTERIDACEAE}

Acrostichum aureum L.

būrete

Widespread in Fiji at the rear of mangrove and in other estuarine situations. No specimen known from Waya, but sighted in the mangrove at Yalobi (obs. ROG 1990s).

\section{Adiantum hispidulum Sw.}

Widespread in Fiji, in open dry places. St John 18081, "tokalo".

\section{* Adiantum trapeziforme L.}

Native to tropical America; naturalized in Fij on Waya, and in southern Viti Levu (Brownsey \& Perrie 2011: 526). $R O G$ 6864, stream $\mathrm{E}$ of Koroimatalevu peak (high point $\mathrm{S}$ of Lekutu), local in open hillside regrowth.

Antrophyum plantagineum (Cav.) Kaulf. Widespread in Fiji's wetter forests. St John 18048.

\section{Cheilanthes nudiuscula (R.Br.) T. Moore}

Local in Fiji (Waya and the three largest islands), in dry open rocky places. St John 18148. ROG 6453, slope W of Yalobi, occ. on rocky ledges. Formerly known as $C$. hirsuta.

\section{Doryopteris concolor (Langsd. \& Fisch.) Kuhn}

Widespread in Fiji in dry open rocky places, sometimes on limestone. St John 18083, "turalo". ROG 6454, 11311 , slope W of Yalobi, occ. on rocky ledges.

\section{Haplopteris elongata (Sw.) E.H. Crane}

Widespread in Fiji's wetter forests. St John 18049, "o ni koro". Formerly known as Vittaria elongata.

\section{Pteris tripartita Sw.}

Widespread in Fiji. ROG 6515, slope NW of Vatunareba peak, local in open forest of bouldery slope on good soil, "[a kind of] balabala".

\section{* Pteris vittata $\mathrm{L}$.}

Probably not native to Fiji (rare here, known only from Waya and Viti Levu). ROG 6536, high point on E side of Olo stream, local on burnt knoll, on shallow soil; Dicranopteris and Pteridium also seen only here.

\section{Taenitis pinnata (J. Sm.) Holttum}

Rather local in Fiji, in mesic and somewhat shaded forest sites. St John 18063, "totondro lo". ROG 6755, peaks E above Yalobi gardens, local in shady dry forest.

\subsection{SCHIZAEACEAE}

Schizaea dichotoma (L.) Sm.

Widespread in Fiji, in all vegetation types, from Pteridium fernland to dense forest. St John 18020, "seisei”.

\subsection{SELAGINELLACEAE}

\section{Selaginella firmula A. Braun ex Kuhn}

Endemic to Fiji, widespread in forest, often abundant. St John 18022. ROG 6866, stream E of Koroimatalevu (high point S of Lekutu), on stiff clay at edge of stream terrace in shady forest.

\section{Selaginella laxa Spring}

Widespread in Fiji in damp to mesic open forests. No specimen known from Waya, but seen by $R O G$ in 2017 , on Vatunareba (soil overhangs at upper edge of shady ravines), and along the higher part of Olo stream, in scrubby cover close to the water.

\section{Selaginella victoriae T. Moore}

Endemic to Fiji, in mesic to rather dry forests, widespread. St John 18021, "mbambaranga”. ROG 6340 , Nagwa, locally common in older forest.

\subsection{TECTARIACEAE}

Tectaria latifolia (G. Forst.) Copel.

Widespread and often abundant in Fiji's drier forests. St John 18014, "gutivi". ROG 6303, Olo stream, abundant among rocks in relic streamside forest.

\subsection{THELYPTERIDACEAE}

Macrothelypteris torresiana (Gaudich.) Ching Local in Fiji, mainly on the two largest islands, in dry open sites. ROG 6418, slope above Naseva Beach, among boulders in open forest.

Sphaerostephanos invisus (G. Forst.) Holttum digi Common in Fiji, in open ground. ROG 6314, E of Olo stream, occ. in rocky tall forest on slope.

\subsection{CYCADACEAE}

Cycas celebica Miq. niuniu Common in drier regions of Fiji. St John 18045, "wiro". $R O G$ 6419, slope above Naseva Beach, abundant in burnt scrub and grassland, only the youngest leaves nibbled by goats. Sometimes known as Cycas rumphii f. seemannii (de Laubenfels \& Adema 1998: 371). St John's name was misspelt "wairo" by Gardner \& Pawley (2006: 108). 


\section{FLORA, PART 2: MONOCOTYLEDONS}

\subsection{ARACEAE}

\section{Alocasia macrorrhizos (L.) G. Don}

via sam

Anciently cultivated in Fiji, often persisting or naturalizing at least by vegetative means. $R O G$ 6356, gardens in valley NW of Yalobi, scattered in the lower, damper places, ripe fruit. $R O G$ 6513, slope NW of Vatunareba, common in open forest on bouldery slope, in good soil.

\section{Amorphophallus paeoniifolius}

(Dennst.) Nicolson

abia $s \bar{a}$

Widespread in Fiji (anciently introduced ?) mainly in disturbed coastal forest. ROG 6517, slope NW of Vatunareba, occ. in open forest on good soil of bouldery slope.

Cyrtosperma merkusii (Hassk.) Schott via kau Anciently cutivated in Fiji, often naturalized in wet places. $R O G$ 6333, gardens in valley NW of Yalobi, cultivated. Formerly known in the central and eastern Pacific as C. chamissonis.

Epipremnum pinnatum (L.) Engl. alu Common in Fiji's forests. St John 18056. ROG 6309, Olo stream, climbing over rocks and trees in shady streamside forest.

\subsection{ARECACEAE}

Cocos nucifera $\mathrm{L}$. niu

Ubiquitous in Fiji. No specimen known from Waya. Sighted by ROG (1990s, 2017) at Yalobi, etc., cultivated, and sporadic in coastal forest.

Pritchardia pacifica Seem. \& H. Wendl. māsei Widely cultivated in Fiji since pre-European times. No specimen is known from Waya, but the plant was sighted by $R O G$ at Yalobi in 2017, where a tree c. 5 $\mathrm{m}$ tall stands at the site of the former bure of the Tui Waya. There are no wildings on the scrubby slopes around, perhaps because the seeds are avidly eaten by rats (D. Watling, pers. comm. 2014). Illn: FV t. 79.

\subsection{ASPARAGACEAE}

Cordyline fruticosa (L.) A. Chev. $\bar{a} k o t o$, qolo Widespread in Fiji, in cultivation and as a forest understorey plant. St John 18075. ROG 6319, gardens in valley NW of Yalobi, occ. in relic forest. Illn: FV t. 94, as Dracaena sepiaria.

\subsection{CYMODOCEACEAE}

\section{Halodule pinifolia (Miki) den Hartog}

lēcau

Widespread and often abundant on Fiji's coast. ROG 6449 , between Yalobi and Naseva Beach, local on shallow sandy reef-flat. $R O G$ 6831, Yalobi, a few patches on sand on coral platform a short way below high-water mark, with Halophila minor.
Syringodium isoetifolium (Aschers.) Dandy lēcau Quite frequent on Fiji's muddy reef-flats. ROG 6829, beach at Yalobi, abundant in the drift.

\subsection{CYPERACEAE}

\section{Carex brunnea Thunb.}

In Fiji known just from the highest part of Waya (Gardner 1997: 491). ROG 6508, 6672, SE Vatunareba, locally common in open forest above c. $300 \mathrm{~m}$, amongst Scleria lithosperma.

\section{Carex dietrichiae Boeck.}

In Fiji's forests, perhaps widespread. ROG 6849, E side of peaks above Waya Levu, in ridge thicket. Listed as a dry-zone Fijian forest species by Keppel \& Tuiwawa (2007: 561). Fig. 4

\section{Cyperus javanicus Houtt.}

Common in Fiji, usually near beaches and creek mouths. ROG 6396, Waya Levu, on gravel berm at beach rear. Sometimes known as Mariscus javanicus.

Fimbristylis cymosa $\mathrm{R}$. Br.

Uncommon in Fiji (Viti Levu and Viwa I.), on rocks at the coast. No specimen known from Waya, but sighted on Viwa I. in July 1992; see label of ROG 6771, Sesuvium portulacastrum.

\section{Fimbristylis dichotoma (Burm. f.) Kern}

Abundant in Fiji, usually weedy in open ground. $R O G$ 6302 , near sandy mouth of Olo stream.

\section{Fimbristylis ovata (Burm. f.) Kern}

Widespread in Fiji in dry open ground. St John 18129, "dodobawale". ROG 6803, above Yalobi school, common among grasses on dry hillside.

\section{Gahnia aspera (R. Br.) Spreng.}

In Fiji's dry forests, infrequent. ROG 6460, slope $\mathrm{W}$ of Yalobi, rare in forest of dry gully, ripe fruit. Listed as a dry-zone forest species by Keppel \& Tuiwawa (2007: 561).

\section{Rhynchospora corymbosa (L.) Britton}

Abundant in Fiji, in swamps, along streams, and as a weed. St John 18080, "o nice". ROG 6802, Yalobi, in wet ground below school water-tanks, not seen elsewhere.

\section{Scleria lithosperma (L.) Sw.}

Widespread and abundant in Fiji. St John 18015, "weisa". ROG 6254, Yalobi, $30 \mathrm{~cm}$ high tussocks, common in dryish scrub, ripe fruit.

Scleria polycarpa Boeck. benici

Abundant in Fiji's drier forests. St John 18016, "nitiniti". ROG 6253, Yalobi, to c. $1.5 \mathrm{~m}$ tall, in dryish open scrub and on grassy hillsides; ripe fruit. 


\subsection{DIOSCOREACEAE}

Dioscorea bulbifera L.

qwā karai

Widespread in Fiji in dry open places. ROG 6342, near Nagwa, abundant in overgrown garden. ROG 6437, valley NW of Yalobi, regrowing abundantly on recently burnt slopes.

Dioscorea pentaphylla $\mathrm{L}$. kwaileni

Widespread in Fiji in dry open places. ROG 6468, Lekutu, in aqona garden, perhaps kept on from the wild.

\subsection{HEMEROCALLIDACEAE (APG IV: Asphodelaceae)}

Geitonoplesium cymosum (R. Br.)

A. Cunn. ex Hook.

wā bitubitu

Local in Fiji's forests (mainly Viti Levu). ROG 6806, peaks $\mathrm{E}$ above gardens in valley NW of Yalobi, climbing at scrub margin on dry ridge, uncommon here, not seen elsewhere on island.

\subsection{HYDROCHARITACEAE}

Halophila minor (Zoll.) den Hartog Abundant on Fiji's shores. ROG 6813, Yalobi, a few patches on sand at $\mathrm{W}$ end of beach.

\subsection{ORCHIDACEAE}

\section{Calanthe triplicata (Willemet) Ames}

Common in Fiji's forests. ROG 6486. peaks W above old Nagwa village site, on ground in dense forest, away from goats.

Dendrobium tokai Reichenb. f. ex Seem.

Widespread epiphyte in Fiji's forests. St John 18051, "viavia ni delana". ROG 6696. SE slopes of Vatunareba, in dry forest, rare here.

\section{Eulophia pulchra (Thouars) Lindl.}

Scattered in Fiji's lower-altitude forests (Waya and five other islands). St John 18024, Olo Creek, N of Yalobi, "parapara".

\section{Liparis condylobulbon Rchb. $\mathrm{f}$.}

Widespread and oftenabundant in Fiji's drier forests. $R O G$ 6812, peaks $\mathrm{E}$ above gardens in valley $\mathrm{NW}$ of Yalobi, low on tree trunk in open Geissois forest.

\section{Oberonia equitans (G. Forst.) Mutel}

Widespread in Fiji's drier forests (most common on Viti Levu). ROG 6847, E side of peaks above Waya Levu, epiphytic in open ridge-crest thicket, at one place only.

Pseuderia smithiana C. Schweinf.

Endemic to Fiji, rather local (Waya, Viti Levu, Vanua Levu, Kandavu). St John 18158, close to rocky summit, climbing over trees, "theme".
Spathoglottis pacifica Rchb. f.

Widespread and abundant in Fiji's grassland and dry open scrub. St John 18069, "varavara". ROG 6823, SE side of ridge above Yalobi-Waya Levu track, in light Arytera-Guioa dry forest.

Taeniophyllum fasciola (G. Forst.) Seem.

Widespread in Fiji, in forest and often on cultivated trees too. No specimen known from Waya; seen by $R O G$ in 2017 in forest on SE slope of Vatunareba.

\subsection{PANDANACEAE}

Freycinetia urvilleana Hombron \& Jacq. $\quad w \bar{a} m \bar{e}$ Widespread in the forests of Fiji (known from six high islands, including Waya). ROG 6715, high point NE of Olo stream, common low climber in forest around summit. The Fijian plants are sometimes segregated as the endemic F. milnei Seem.

Pandanus tectorius Sol. ex Parkinson vadra Common in coastal parts of Fiji. St John 18132, "vandu [va $d u$ ]", 18138, "vandra". ROG 6481, slope W of Yalobi, $3 \mathrm{~m}$ tall in forest of rocky gully, ripe fruit. The Wayan plants have been segregated as $P$. yasawaensis. This is said to have notably small (4 cm long) phalanges, and to grow only on Waya and in the vicinity of Sigatoka on Viti Levu (FVN 1: 489). It seems likely it is just a small-leaved inland ecotype of $P$. tectorius.

\subsection{POACEAE}

* Cenchrus polystachios (L.) Morrone manivusi Introduced to Fiji, now abundant in the dry grasslands of the two largest islands, and on Waya. ROG 6300, Yalobi, dominating dry grassy slope. Formerly known as Pennisetum polystachyon.

\section{Centotheca lappacea (L.) Desv.}

Widespread in Fiji's forests. No specimen known from Waya; presumed present but rare.

\section{Chrysopogon aciculatus (Retz.) Trin.}

Widespread in Fiji, often near the coast. No specimen known from Waya; seen by $R O G$ in 2017 on dry grassy slopes above Yalobi.

Coix lacryma-jobi L. sìlā

Widespread in Fiji, weedy in damp open sites. $R O G$ 6369 , near Nagwa, local at stream edge.

\section{* Cymbopogon coloratus}

(Hook. f.) Stapf $\bar{o}$ cagicagi

An introduction, now found locally in Fiji (Waya, Viti Levu) in dry open places. ROG 6738, SE slopes of Vatunareba, open lava slope, one tussock on soil patch. Brought to Fiji from India in the early 1900s in error for the true lemon-grass C. citratus (FVN 1: 380); wrongly noted as indigenous to Fiji by Gardner \& Pawley (2006: 103). 
Cymbopogon refractus $\mathrm{R}$. $\mathrm{Br}$.

$\bar{o}$ cagicagi

Widespread in Fiji on dry open hillsides. St John 18102. Gardner \& Pawley (2006: 103) may have been wrong in saying that this grass is not indigenous to Fiji.

\section{Cyrtococcum oxyphyllum (Hochst. ex Steudel) Stapf}

Widespread in Fiji, in light dry forest and as a weed. St John 18127, "o salasala". ROG 6313, east of Olo stream, common grass of shady tall relic forest in dryish gullies.

\section{Digitaria setigera Roth ex Roem. \& Schultes}

Widespread but uncommon in Fiji. No specimen known from Waya; presumed present.

\section{Heteropogon contortus (L.) P. Beauv.} ex Roem. \& Schultes

Local in drier regions of Fiji (the two largest islands, and Waya). in grassland . ROG 6804, Yalobi, above the school, local on dry grassy ridge, $40 \mathrm{~cm}$ tall.

\section{Imperata conferta (J. Presl) Ohwi}

$\bar{o}$ tirau

Widespread Fiji on hillsides and as a weed, but said not to cover extensive areas (FVN 1: 365). ROG 6509, slope SW of Yalobi, uncommon in soil remnants of eroded slope. The similar-looking Imperata cylindrica (L.) P. Beauv. is said to occur in Fiji (Clayton \& Snow 2010: 81). The single, Wayan specimen (cited here) is more like $I$. conferta in its inflorescence, but lacks fertile spikelets. It was identified as I. cylindrica by Gardner \& Pawley (2006: 103).

Lepturus repens (G. Forst.) R. Br.

Widepread on Fiji's coast. No specimen known from Waya; presumed present.

\section{Miscanthus floridulus (Labill.) Warb.}

ex K. Schum. \& Lauterb. ō sina, sina Widespread in Fiji's dry zone grasslands. ROG 6269, Yalobi, to $2 \mathrm{~m}$ tall, abundant on the island's burnt-over hillsides.

Oplismenus compositus (L.) Beauv.

Widespread in Fiji's forests. No specimen known from Waya; seen by $R O G$ in 2017 on forest edges at mid-altitude on Vatunareba. For a treatment of this taxon as three species see Clayton \& Snow (2010: 52)

\section{Paspalum scrobiculatum L.}

Widespread in Fiji, often with Dicranopteris linearis in open infertile (wet or dry) sites.

$R O G$ 11316, inland from Yalobi, at edges of waterfilled pools in rocky outcrops in grassland, and local on dry grassy hillside. Often known, in the Pacific Ocean region, as $P$. orbiculare.

\section{Schizostachyum glaucifolium}

(Rupr.) Munro

bitu dī, ō bitubitu

Widely cultivated in Fiji. ROG 6417, slope above Naseva Beach, at foot of cliffs below peaks, a few groves in open forest, the culms to c. $6 \mathrm{~m}$ tall and $7 \mathrm{~cm}$ $\varnothing$. The status of this bamboo is unclear; some consider it a Fijian endemic, or at least, indigenous there (FVN 1: 294; W. A. Whistler, pers. comm.).

\section{Stenotaphrum micranthum (Desv.) Hubbard}

Widespread on Fiji's coast, perhaps most abundant on the smaller islands. No specimen known from Waya; presumed present.

Thuarea involuta (G. Forst.) R. Br. ex Sm. Widespread on Fiji's coast. ROG 6291, Yalobi, plentiful along stable sandy foreshore.

\subsection{SMILACACEAE}

Smilax vitiensis (Seem.) A. DC. in DC. wā bitubitu Abundant and widespread in Fiji. St John 18025, "wa $m e$ ". ROG 6487, track between Yalobi and Nalauwaki, in dense forest at the peaks W of Nagwa. ROG 6712, towards high point NE of Olo stream, in open ridge forest below summit. Illn: FV t. 93, as Pleiosmilax vitiensis.

\subsection{TACCACEAE (APG IV: Dioscoreaceae)}

Tacca leontopetaloides (L.) Kuntze abia $d \bar{u}$ Widespread in Fiji's coastal forests; perhaps an ancient naturalization. St John 18028.

\subsection{XANTHORRHOEACEAE (APG IV: Asphodelaceae)}

Dianella adenanthera (G. Forst.) R.F. Henderson Widespread in Fiji's drier forests. ROG 6709, towards high point NE of Olo stream, local in open ridge forest, inflorescence notably fragile. Not included in the dry-zone forest species-list of Keppel \& Tuiwawa (2007).

\subsection{ZINGIBERACEAE}

Curcuma longa L.

reregwa

Anciently cultivated in Fiji. St John 18027. ROG 6661, Yalobi, abundant on dry grassy slope, having spread vegetatively downslope from an old garden, apparently able to resist fire.

Zingiber zerumbet (L.) Sm. cegwata Anciently cultivated in Fiji. ROG 6366, near Nagwa, common in open forest, not flowering, no old fruit seen. 


\section{FLORA, PART 3: DICOTYLEDONS}

\subsection{ACANTHACEAE}

Graptophyllum insularum (A. Gray) A.C. Sm. Widespread and abundant in Fiji. St John 18107. $R O G$ 6440, towards the peaks $\mathrm{N}$ of Yalobi, above the gardens, in scrub on ridge crest. $R O G 6710$, towards high point NE of Olo stream, local in open ridge forest, flrs without scent.

\subsection{AIZOACEAE}

Sesuvium portulacastrum (L.) L

Widespread but rather local on Fiji's coast. No specimen known from Waya, Present on Viwa I.: ROG 6771, on coral with Fimbristylis cymosa.

\subsection{AMARANTHACEAE}

\section{*Achyranthes aspera $\mathrm{L}$.} sorisori tavui

Widespread weed in Fiji. ROG 6664, above Olo stream, in scrub below rock face. The Fijian plants belong to var. pubescens (Moq.) C.C. Towns.

Deeringia amaranthoides (Lam.) Merr. tokoi Rather local on Fiji's coast (Waya, Viti Levu and several other islands). ROG 6834, E end of Yalobi, $1.5 \mathrm{~m}$ tall bush, rare in coastal forest; leaves said to be cooked and eaten with octopus [cf. resemblance between animal's tentacles and plant's infructescence].

\subsection{ANACARDIACEAE}

Dracontomelon vitiense Engl.

tawarau

Scattered in Fiji's drier forests, also a village tree. $R O G$ 6530 , slope E of Olo stream, behind the school on dry slope, several $15 \mathrm{~m}$ tall $70 \mathrm{~cm}$ dbh buttressed trees.

Pleiogynium timoriense (DC.) Leenh.

Widespread and abundant in Fiji's drier forests, but apparently rare on Viti Levu. St John 18120. ROG $6458,6466,6474 \& 6480$, slope W of Yalobi, 4-5 m tall, in forest of rocky gully. ROG 6730, above Naseva beach, fruit ripe, skin pinkish crimson, the flesh of similar colour and with a slippery-mealy texture, slightly acid, not sweet but not unpalatable. Although not uncommon on Waya, no local name has been obtained for it.

\section{Rhus taitensis Guillemin} manaw̄ Widespread in Fiji, often abundant in dry scrub and secondary forest. St John 18067, "tawarau". ROG 6420 , above Naseva beach, $6 \mathrm{~m}$ tall $25 \mathrm{~cm}$ dbh, in open forest. $R O G$ 6482, W above Nagwa, $4 \mathrm{~m}$ tall, in scrub on rocky slope. Sometimes known as $R$. simarubifolia. 1ln: USEE 15, Atlas pl. $44 \mathrm{~B}$, as Rhus simarubaefolia.

\section{Semecarpus vitiensis (A. Gray) Engler}

Widespread in Fiji's drier forests. ROG 6435, towards peaks $\mathrm{N}$ of Yalobi, above village's gardens, $12 \mathrm{~m}$ tall 30 $\mathrm{cm} \mathrm{dbh}$, in forest among boulders. Illn: USEE 15, Atlas pl. 43, as Oncocarpus vitiensis.

\subsection{APIACEAE}

Centella asiatica (L.) Urb. totodro Abundant in Fiji. ROG 6363, ridge above Yalobi, occ. at edge of track through grassland.

\subsection{APOCYNACEAE}

Alyxia bracteolosa A. Gray

vono Common in Fiji (Waya and six other high islands), in open drier sites. St John 18117. ROG 6756, peaks E above Yalobi village gardens, local in open ridge forest. At least some of the Wayan plants have been placed in a narrow-leaved variety, var. angustifolia A. Gray, which is said to occur in Fiji (Waya and three other high islands) and Tonga. However, this variety is not maintained by Middleton (2002).

Alyxia stellata (J.R. \& G. Forst.) Roem. \& Schult. Widespread in Fiji, in open drier sites. St John 18052 \& 18161, "vono"; St John 18113, "vundi".

Cerbera manghas $\mathrm{L}$. rewa Widespread in Fiji. ROG 6347, W above Nagwa, trees to $8 \mathrm{~m}$ tall $20 \mathrm{~cm} \mathrm{dbh}$, common in secondary forest, not eaten by goats. ROG 6678, SE slopes of Vatunareba, $4 \mathrm{~m}$ tall $10 \mathrm{~cm} \mathrm{dbh}$, in dry open forest. A colonizer of grassy slopes, the fruits being dropped there by fruit-bats.

\section{Melodinus glaber Turrill} wata

Local in Fiji (Waya and the two largest islands). St John $18053 \mathrm{~A}$, "wata". ROG 6475, slope W of Yalobi, vine to $5 \mathrm{~m}$ high in forest of rocky gully.

Ochrosia oppositifolia (Lam.) K. Schum. vāō Widespread but rather local on Fiji's coasts. The species seems not to grow on Waya but does occur on nearby islets, e.g., ROG 6853, W side of Narara I., trees to $8 \mathrm{~m}$ tall, locally common on rocky slopes just above high-water; this stand said to provide house-posts for the Wayan people. Formerly known as Neisosperma oppositifolium.

\section{Ochrosia vitiensis (Markgraf) Pichon}

Local in Fiji's coastal forests. ROG 6784, gap in ridge $\mathrm{S}$ of Vatunareba summit, one $2 \mathrm{~m}$ tall treelet in dry scrub.

Tabernaemontana pandacaqui Lam. lāqaiqai Common in Fiji's drier light and rocky forests. St John 18149, "totoka". DA 13656. ROG 6305, Olo stream, among rocks in streamside forest; abundant elsewhere 
on the slopes, not eaten by goats. $R O G 6674$, SE slopes of Vatunareba, abundant in dry open places, ripe fruit. Formerly known as Ervatamia obtusiuscula. The first two specimens above are said to belong to a "narrowleaved form", which is found elsewhere in Fiji besides Waya (FVN 4: 98).

\subsection{ARALIACEAE}

\section{Polyscias multijuga}

\section{(A. Gray) Harms}

walanibekwa

Widespread and abundant in Fiji's forest and forest regrowth. St John 18104, "wala nimbergua". ROG 6271, Yalobi, $2.5 \mathrm{~m}$ tall, in scrub and open forest, infl. with female flrs proximally and males distally. Illn: FV t. $18 \& 19$, as Nothopanax multijugum.

\subsection{ASCLEPIADACEAE (APG IV: Apocynaceae)}

Hoya australis $\mathrm{R}$. Br.

Widespread in Fiji, often abundant in dry coastal forest. St John 18164. ROG 6307, Olo stream, above the washing place, uncommon in scrub of gorge. $R O G$ 11323, gully on lower E slope of Vatunareba, epiphytic with Drynaria, flrs fragrant.

Sarcolobus stenophyllus (A. Gray) P.I. Forst. Endemic to Fiji, rare (Waya and northern Vanua Levu). St John 18032, “langaingai”. Illn: FV t. 31, as Gymnema stenophyllum. Formerly known as Leichardtia stenophylla (FVN 4: 114; Forster 1992). Apart from the Wayan collection, only three 20th C. collections are known.

\subsection{ASTERACEAE}

Wollastonia biflora (L.) DC.

Widespread on Fiji's rocky shores. St John 18011 , "thekawa".

\subsection{BALANOPHORACEAE}

Balanophora fungosa J.R. \& G. Forst. varavara Apparently rather local in Fiji's forests. St John 18029. $R O G 6747$, E side of peaks above Waya Levu, in open mesic forest on good soil, also nearby in old Hibiscus tiliaceus scrub on fine talus; male flrs ochre-yellow and pollen white, female flrs brown. The Fijian population belongs to subspecies fungosa, whose members are monoecious.

\subsection{BARRINGTONIACEAE}

(APG IV as Lecythidaceae) Barringtonia asiatica (L.) Kurz

Widespread and abundant on Fiji's coast. No specimen known from Waya; commonly observed, e.g., at Yalobi (ROG 1990s \& 2017).
Barringtonia edulis Seem.

kutuvala

Endemic to Fiji; known from forests on Waya and several other high islands. ROG 6317, E of Olo stream and school, common in relic forest among boulders; fruit green, bat-chewed stones on ground. ROG 6717, loc. supra, trees to $20 \mathrm{~m}$ tall, regenerating in rocky gully.

\subsection{BORAGINACEAE}

Cordia subcordata Lam.

nawanawa

Widespread on Fiji's coast. ROG 6861, Yalobi, near Olo, $7 \mathrm{~m}$ tall $30 \mathrm{~cm}$ dbh trees, locally common in sand among rocks just above HWM, ripe fruit. Illn: FV t. 34 .

\section{Heliotropium foertherianum}

Diane \& Hilger

Widespread on Fiji's coast. No specimen known from Waya; presumed present on Viwa I. Formerly known as Argusia argentea.

\subsection{CAPPARIDACEAE}

\section{Capparis cordifolia Lam.}

Apparently rather local on Fiji's coast. No specimen known from Waya, but there is one from Viwa I.: ROG 6770 , on coral among Casuarina, Pemphis, Guettarda, "bēbē ni vatu".

\subsection{CASUARINACEAE}

Casuarina equisetifolia J. R. \& G. Forst. velau Widespread in Fiji. St John 18155.

\subsection{CELASTRACEAE}

Cassine vitiensis (A.C. Sm.) A.C. Sm.

Endemic to Fiji (Waya, Viti Levu, Ovalau). ROG 6787, towards summit of Vatunareba, $8 \mathrm{~m}$ tall $15 \mathrm{~cm}$ dbh, uncommon in gully forest.

\section{Celastrus richii A. Gray}

Endemic to Fiji, rather uncommon. St John 18053. ROG 6502, slope $\mathrm{W}$ of Yalobi, towards Vatunareba, liane in open forest. ROG 6724, SE slope of Vatunareba, brittle-stemmed liane, common in dry open forest, ripe fruit, each with six seeds.

\subsection{CLUSIACEAE (APG IV: Calophyllaceae)}

Calophyllum inophyllum $\mathrm{L}$. dilo Abundant on Fiji's coast. St John 18903. ROG 6359, Yalobi, at the Sayaba compound, $3 \mathrm{~m}$ tall tree on sand at rear of beach, ripe fruit.

Calophyllum vitiense Turrill damanu

Endemic to Fiji (Waya, Viti Levu, Vanua Levu and several other high islands). ROG 6527, Lekutu, $8 \mathrm{~m}$ tall $15 \mathrm{~cm}$ dbh tree by stream; 6674, loc. cit., $10 \mathrm{~m}$ tall 30 $\mathrm{cm}$ dbh tree, fruit on ground, probably ripe. 
Garcinia pseudoguttifera Seem.

suweru

Widespread in Fiji's forests. St John 18072,

"nambulinomati". ROG 6345, Nagwa, treelet $3 \mathrm{~m}$ tall, locally common in older forest. ROG 6748, E side of peaks above Waya Levu, $4 \mathrm{~m}$ tall, common in forest.

\subsection{COMBRETACEAE}

Terminalia catappa $\mathrm{L}$.

Abundant in Fiji's coastal forests. St John 18094, "tavola". ROG 6278, Olo end of Yalobi, occ. in open forest. $R O G$ 6668, above Olo stream, $10 \mathrm{~m}$ tall, in streamside forest, ripe fruit.

\section{Terminalia litoralis Seem.}

Abundant in Fiji's coastal forests. ROG 6720, Olo stream mouth, $6 \mathrm{~m}$ tall, above mangrove.

\section{Terminalia vitiensis A.C. Sm.}

Endemic to Fiji (Waya and south-central coast of Viti Levu), in dry forest. ROG 6682, SE slopes of Vatunareba, $4 \mathrm{~m}$ tall $10 \mathrm{~cm}$ dbh, uncommon, bark hard, scaly and fissured; flrs lemon-yellow, not scented; fruit unripe, winged along each side. Fig. 3.

\section{Connarus pickeringii A. Gray}

Endemic to Fiji, widespread in drier forests. St John 18130, "wa vatu". ROG 6499, slope W of Yalobi, locally common in forest of rocky gully. Illn: USEE 15, Atlas pl. 45.

\subsection{CONVOLVULACEAE}

Evolvulus alsinoides (L.) L.

Uncommon in Fiji (Waya and Navutu-i-loma), in dry open places. St John 18134,"o-chichi". ROG 13030, E side of Vatunareba, steep open slope, local on thin soil.

\section{Ipomoea littoralis $\mathrm{Bl}$.}

sovivi

Widespread on Fiji's coasts. ROG 11313, slope W of Olo stream, uncommon scrambler in open scrub.

Ipomoea pes-caprae (L.) R. Br. $\quad w \bar{a}$ vulavula Widespread on Fiji's sandy shores. ROG 6444, Naseva beach, on sand-berm above drift-line.

\section{Merremia peltata (L.) Merr.}

veliawa

Widespread in Fiji, especially in disturbed forest. No specimen known from Waya. Abundant in forest at top of Olo Creek (obs. ROG, 2017).

\section{Operculina turpethum (L.) A. Silva Manso}

Widespread in Fiji. ROG 6395, near Waya Levu, vine in scrub, ripe fruit. $R O G 11317, \mathrm{~W}$ of middle part of Olo stream, locally common in rather damp place in scrubby grassland.

\subsection{CUNONIACEAE}

Geissois ternata A. Gray

vuga

Endemic to Fiji; known from drier forests on at least six of the high islands, including Waya. St John 18128. ROG 6376, Lekutu forest between Yalobi and Nalauwaki, $10 \mathrm{~m}$ tall $40 \mathrm{~cm}$ dbh, locally dominant. $R O G 11340$, above mid- part of Olo stream, relic tree in grassland, $8 \mathrm{~m}$ tall.

The St John collection is said to belong to the endemic var. serrata A.C. Sm., which has large, conspicuously toothed leaflets and bristly-hairy stipules (FVN 3: 18). $R O G 6376$ has such stipules, but its leaflets are subentire. Recorded as a dry-zone forest species by Keppel and Tuiwawa (2007), but apparently infrequent at their study sites. Illn: USEE 15, Atlas pl. 86.

\section{Weinmannia vitiensis Seem.}

Endemic to Fiji (Waya, Kadavu, Moala, Taveuni). ROG 6704, towards high point NE of Olo stream, $5 \mathrm{~m}$ tall multi-trunked tree on forest margin. ROG 6789, $4 \mathrm{~m}$ tall bushes, local towards ridge crest.

\subsection{DICHAPETALACEAE}

Dichapetalum vitiense (Seem.) Engl.

Widespread in Fiji but rather local ROG 6433, towards the peaks $\mathrm{N}$ of Yalobi, liane, stems $1 \mathrm{~cm} \varnothing$, in forest. $R O G$ 6750, E side of peaks above Waya Levu, uncommon in open forest.

\subsection{DILLENIACEAE}

Dillenia biflora (A. Gray) Martelli kulukulu Widespread in Fiji's forests (Waya, the three largest islands and Ovalau). ROG 6335, Nagwa, $10 \mathrm{~m}$ tall 20 $\mathrm{cm} \mathrm{dbh}$, locally abundant in light forest, bark falling in large, nearly square, greyish red flakes. Illn: USEE 15, Atlas pl. 1, as Capellia biflora.

\subsection{EBENACEAE}

Diospyros gillespiei (Fosb.) Kostermans kailo Endemic to Fiji. ROG 6675, 6972, SE slopes of Vatunareba, $4 \mathrm{~m}$ tall $10 \mathrm{~cm} \mathrm{dbh}$, common in dry forest up to $\mathrm{c}$. $300 \mathrm{~m}$. The Wayan plant belongs to var. gillespiei, which is known also from four of the larger islands. Fig. 4.

\section{Diospyros major (G. Forst.) Bakh.}

Widespread in Fiji. St John 18167, "bamba". ROG $6516,3 \mathrm{~m}$ tall $10 \mathrm{~cm}$ dbh, seen once in open forest of ridge below rock peaks, flrs male, apparently opening at night and dropping the next day. ROG 6684, SE slopes of Vatunareba, $3 \mathrm{~m}$ tall treelet, occ. in light forest at higher altitudes. ROG 6760, peaks E above Yalobi village gardens, $2 \mathrm{~m}$ tall, common in ridge thickets. Diospyros phlebodes (A.C. Sm.) A.C. Sm. kailo Endemic to Fiji (the several largest islands, and some smaller ones, often near the coast). 


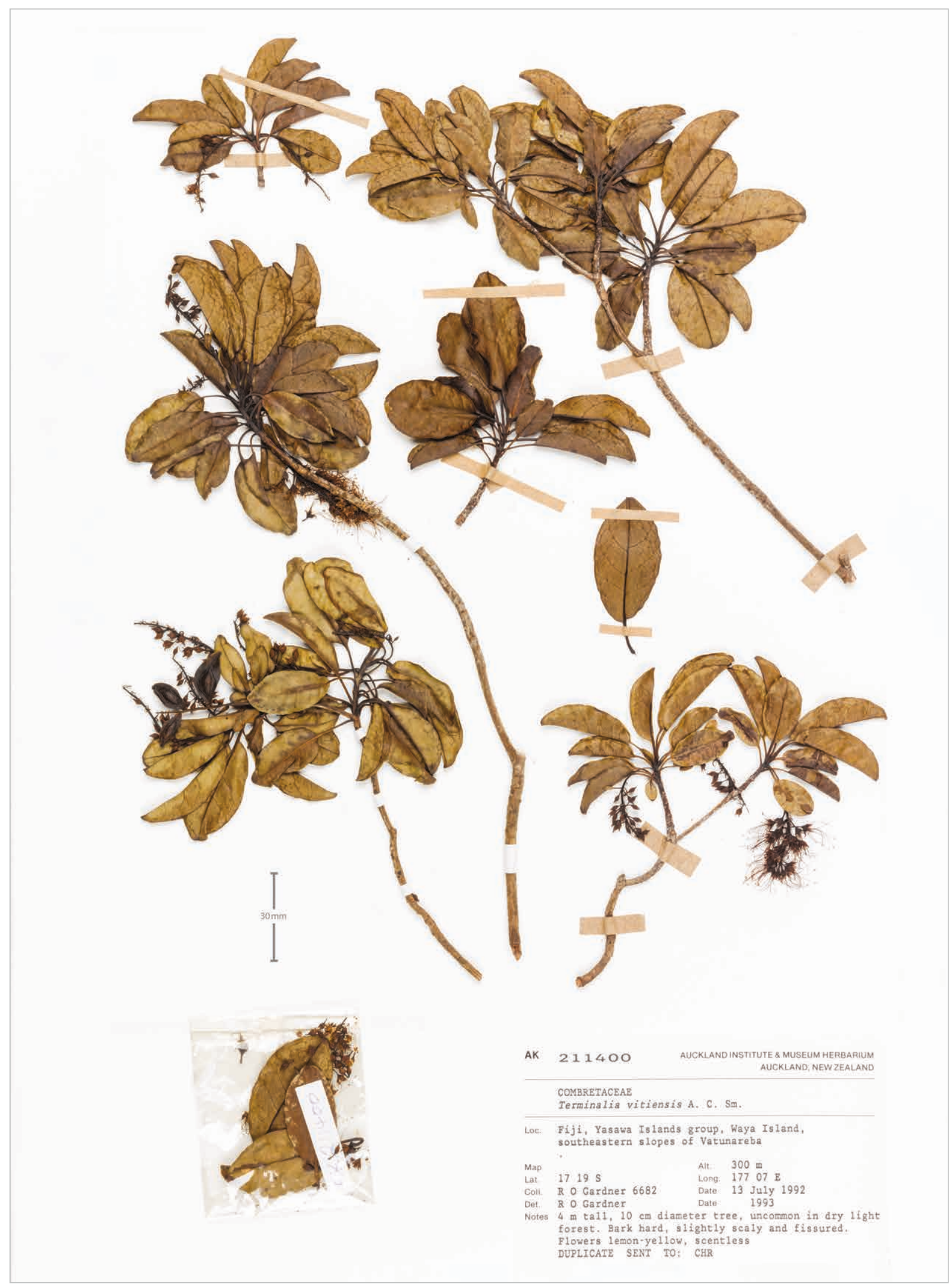

Figure 3. Terminalia vitiensis, AK211400. (c) Auckland Museum CC BY. 


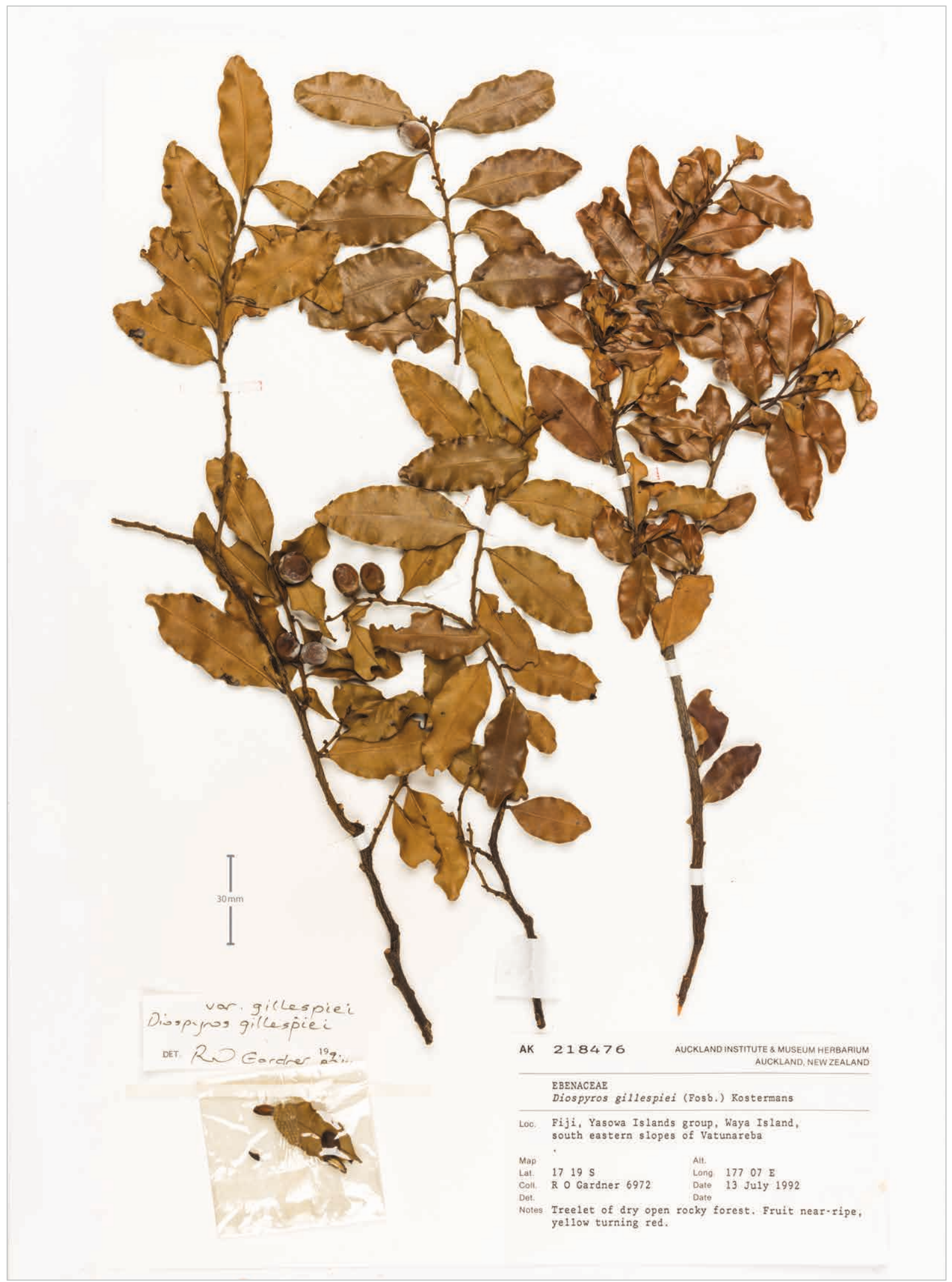

Figure 4. Diospyros gillespiei gillespiei, AK218476. (c) Auckland Museum CC BY. 
ROG 6331, 6430, Yalobi village gardens, trees $2 \mathrm{~m}$ tall, occ. in relic forest on bouldery slope. ROG 6740, 6677, SE slopes of Vatunareba, $4 \mathrm{~m}$ tall, occ. in dry light forest and middle and higher altitudes, fruit ripe. Fig. 5.

\section{Diospyros vitiensis Gillespie}

Endemic to Fiji. St John 18121, "sawira". ROG 6745, -9, E side of peaks above Waya Levu, $3 \mathrm{~m}$ tall treelets in open forest. The Wayan plant belongs to var. longisepala (Gillespie) A.C. Sm., which is also found on Viti Levu and some other high islands.

\subsection{EUPHORBIACEAE}

\section{Acalypha lanceolata Willd.}

Rare in Fiji. No specimen is known from Waya, but the following comes from nearby Naukacuvu I.: ROG 6857, Aug 1992, plant $50 \mathrm{~cm}$ tall, on sandy waste ground around construction site of future resort; presumed to have arisen from the seed-bank. FVN (2: 524, under A. boehmerioides) cites three old collections from Fiji but only one modern one, which supports the idea that the species is an ancient Polynesian weed, unable to compete with more-aggressive newcomers.

\section{Acalypha repanda Muell. Arg.}

karabusi

Widespread in Fiji. St John 18170, "kalambuthi". ROG 6304, Olo, shrub $3 \mathrm{~m}$ tall, common in streamside scrub. ROG 6352, Yalobi, coast E of Olo, $2 \mathrm{~m}$ tall treelets in degraded forest. The Wayan plants belong to var. denudata (Muell. Arg.) A.C. Smith, a small-leaved variety endemic to Fiji and said to be common in the drier zones of Viti Levu and Vanua Levu.

\section{Claoxylon echinospermum Muell. Arg.}

Endemic to Fiji (three highest islands and Waya). ROG 6413, slope above Naseva Beach, $1.5 \mathrm{~m}$ tall treelet in young forest. ROG 6707, towards high point NE of Olo stream, $2 \mathrm{~m}$ tall treelet, local on forest margin.

Codiaeum variegatum (L.) A.H.L. Juss. gwali Widely cultivated (an ancient introduction ?) in Fiji, and often naturalizing. ROG 6741, 6793, E side of peaks above Waya Levu, $3 \mathrm{~m}$ tall, in forest near ridge crest.

Croton metallicus Seem. asiravu

Endemic to Fiji (Waya, Vanua Levu, Kambara). St John 18039, “asirapu”. St John 18119, “asiravu”. ROG 6505 , W side of Vatunareba, near summit, a few $2.5 \mathrm{~m}$ tall bushes, leaves scented of mint and sawdust; orange to crimson when dry. Illn: FV t. 56.

\section{Croton microtiglium Burkill}

Fiji (Waya, Viti Levu and elsewhere). St John 18162, "sobusobu". ROG 6731, SE slope of Vatunareba, $3 \mathrm{~m}$ tall $10 \mathrm{~cm} \mathrm{dbh}$, rare in open forest, perhaps eaten by goats, leaves brittle and hardly fragrant. Illn: FV t. 57, as Croton verreauxii var. storckii.
Euphorbia plumerioides Teijsm. ex Hassk.

Rare on Fiji's rocky coasts (Waya, Viti Levu, and elsewhere). St John 18035, open ledges, $3 \mathrm{~m}$ tall shrub, 600 feet [180 m] a.s.1. "reanitua", medicinal, for constipation. Previously treated as E. fidjiana and said to be endemic to Fiji. Forster (1994: 260) suggests that the plant might not be native to Fiji and that its current sites are mainly where it has been cultivated, e.g., as a garden boundary-marker. Peekel (1984: 320), Henderson \& Hancock (1988: 248) and Hopkins and Menzies (1995: 79) provide ethnobotanical data and illustrations.

Excoecaria agallocha $\mathrm{L}$.

$\operatorname{sinu}$ Widespread on Fiji's coast. St John 18160, "tuku”.

\section{Glochidion concolor Muell. Arg.}

Widespread in Fiji. ROG 6403, Waya Levu gardens, $2 \mathrm{~m}$ tall, in regrowth. $R O G$ 6412, slope above Naseva Beach, crooked treelets $4 \mathrm{~m}$ tall in young forest. $R O G$ 6659,6691 , above Yalobi in thickets on steep slope. The genus is referred by APG IV to the Phyllanthaceae.

Glochidion seemannii Muell. Arg.

Endemic to Fiji (Waya and six other high islands). $R O G$ 6713 , high point NE of Olo stream, $7 \mathrm{~m}$ tall $15 \mathrm{~cm}$ dbh tree at edge of forest. The genus is referred by APG IV to the Phyllanthaceae.

Glochidion vitiense (Muell. Arg.) Gillespie qalo Endemic to Fiji (Waya, and seven other islands). ROG 6476 , slope $\mathrm{W}$ of Yalobi, $3 \mathrm{~m}$ tall tree in forest of rocky gully. The genus is referred by APG IV to the Phyllanthaceae.

Homalanthus nutans (G. Forst.) Guill. Widespread and often abundant in Fiji's secondary forests. St John 18085, "tautau”. ROG 6350, near Nagwa, c. 250 $\mathrm{m}$ alt., treelets to $3 \mathrm{~m}$ tall, dominating some recently burnt slopes, rather infrequent below this altitude.

\section{Macaranga seemannii}

(Muell. Arg.) Muell. Arg. velutu Widespread in Fiji's forests. St John 18074, "velutu". ROG 206377, Yalobi, c. $4 \mathrm{~m}$ tall, cut for firewood. The Wayan plants belong to var. seemannii, which has the range of the species.

Mallotus tiliifolius (B1.) Muell. Arg. aqwata Widespread in Fiji in dry coastal forest. ROG 6258, 6267 , Yalobi village, $4 \mathrm{~m}$ tall, cut for firewood, bark grey-brown, thin and flaky. ROG 6511, slope SW of Yalobi, $4 \mathrm{~m}$ tall $10 \mathrm{~cm} \mathrm{dbh}$, common in open forest of rocky gully, male flrs with a spicy scent.

\section{Phyllanthus virgatus G. Forst.}

Formerly widespread in Fiji (an ancient weed ?), now rare. No specimen is known from Waya, but there is one from elsewhere in the Yasawa Is.: Naviti I., DA 11765. The genus is referred by APG IV to the Phyllanthaceae. 


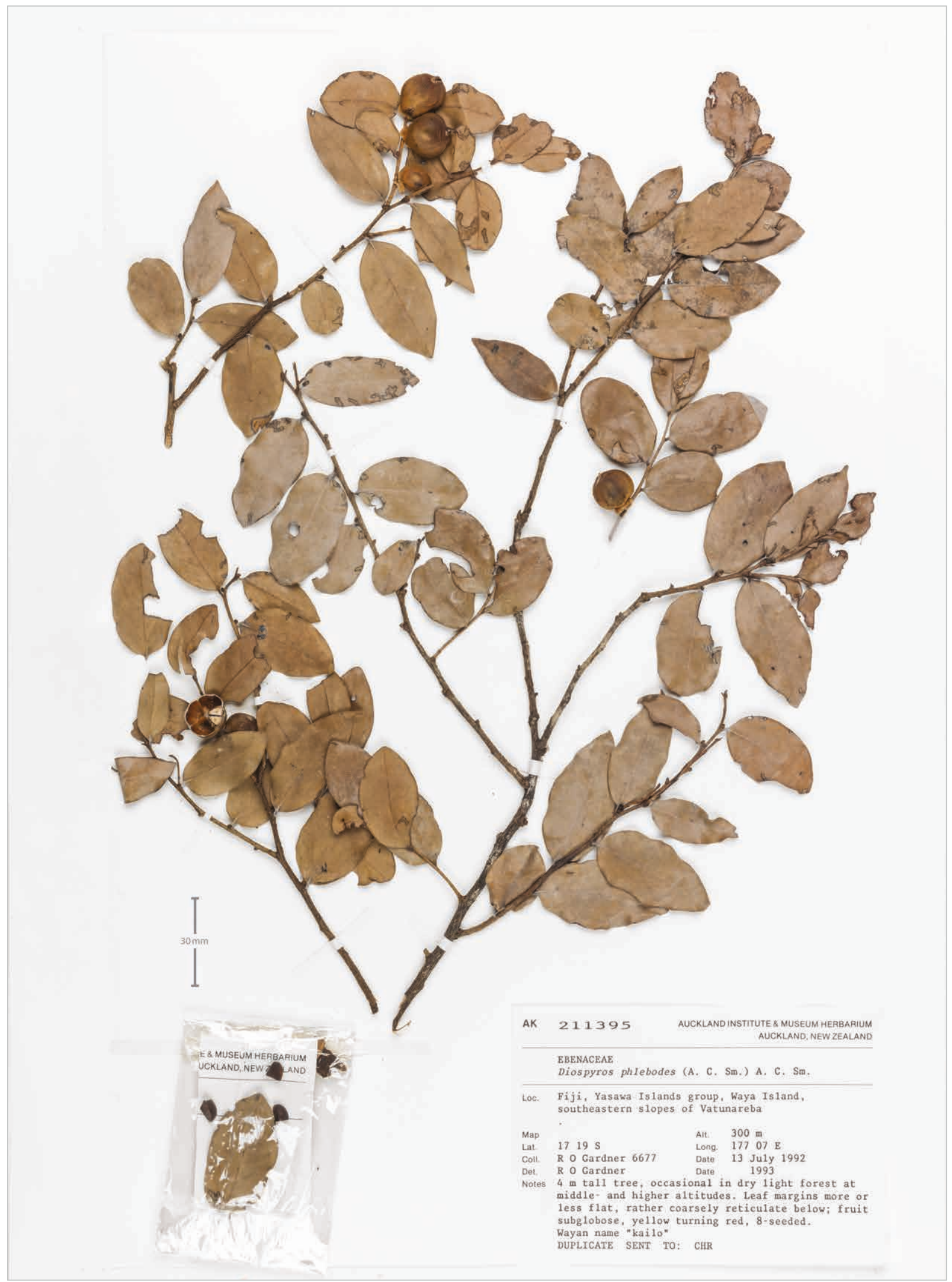

Figure 5. Diospyros phlebodes, AK211395. (c) Auckland Museum CC BY. 
Stillingia pacifica Muell. Arg.

rewarewa

Local on Fiji's coast (Waya, Viti Levu and several other islands). St John 18057, "vasa". DA 13668. ROG 6306 , Olo stream, to $3 \mathrm{~m}$ tall, occ. among rocks in relict streamside forest, abundant elsewhere on dry volcanic slopes, not eaten by goats. $R O G$ 6443, slope above Naseva beach, $3 \mathrm{~m}$ tall, locally dominant on rocky ground, fruit ripe, "rewarewa". Also known as S. lineata (Lam.) Muell. Arg. subspecies pacifica (Muell. Arg.) Steenis.

\subsection{FLACOURTIACEAE (APG IV: Salicaceae)}

Casearia longifolia A.C. Sm.

Endemic to Fiji, dry forest (Waya, Viti Levu). St John 18111, "bombongua". DA 13667. ROG 6405, gardens of Waya Levu village, $3 \mathrm{~m}$ tall in regrowth. ROG 6692, -3, SE slopes of Vatunareba, $3 \mathrm{~m}$ tall, common in dry forest.

\section{Erythrospermum acuminatissimum}

(A. Gray) A.C. Sm.

Widespread in Fiji. St John 18073, "dakariwai". ROG 6495, slope $\mathrm{W}$ of Yalobi, $2 \mathrm{~m}$ tall, occ. in forest of rocky gully, ripe fruit. $R O G 6697$, SE slopes of Vatunareba, $6 \mathrm{~m}$ tall, common here in mid-altitude forest, flrs rose-scented. The genus is referred by APG IV to the Achariaceae.

Flacourtia subintegra A.C. Sm.

Endemic to Fiji ( Waya, Viti Levu Vanua Levu, Ovalau and Vanua Mbalavu). St John 18166 (US), Nakawa Gulch, upper woods, tree $8 \mathrm{~m}$ tall $4 \mathrm{~cm}$ dbh, "ngalo". $R O G$ 11332, foot of rocky slope $\mathrm{W}$ of Yalobi, $10 \mathrm{~m}$ tall $20 \mathrm{~cm}$ dbh sprawling male tree, flrs honey-scented.

\section{Homalium vitiense Benth.}

tura

Endemic to Fiji, rather infrequent, mainly on the two largest islands and Waya. St John 18146. ROG 6421, slope above Naseva Beach, crooked tree $3 \mathrm{~m}$ tall $25 \mathrm{~cm}$ basal $\varnothing$ in scrub on rocky slope. $R O G 6888$, SE slope of Vatunareba, $5 \mathrm{~m}$ tall $15 \mathrm{~cm}$ dbh tree, common in dry open scrub.

Xylosma simulans A.C. Sm.

Fiji (Waya and several other islands but not Viti Levu). St John 18166, "ngalo". ROG 6673, SE slopes of Vatunareba, $3 \mathrm{~m}$ tall, local in dry open scrub.

\subsection{GESNERIACEAE}

\section{Cyrtandra anthropophagorum Seem.}

Endemic to Fiji. $R O G$ 6851, E side of peaks above Waya Levu, $1 \mathrm{~m}$ tall plants in open place in thicket near ridge crest, not seen elsewhere. This is the most widespread and abundant Cyrtandra species in Fiji, presumably because it tolerates relatively dry sites.

\subsection{GOODENIACEAE}

Scaevola sericea Vahl

Widespread on Fiji's coast. ROG 6535, E of Olo stream mouth, $2 \mathrm{~m}$ tall, at rear of beach. Often known as $S$. taccada.

\subsection{GYROCARPACEAE (APG IV: Hernandiaceae)}

Gyrocarpus americanus Jacq. toca, toutou Widespread in Fiji's drier coastal forests. St John 18110, "toto". St John 18151, "toto". ROG 6362, Yalobi, ridge above Sayaba compound, $10 \mathrm{~m}$ tall $50 \mathrm{~cm}$ $\mathrm{dbh}$, in relic forest among boulders. $R O G$ 6827, ridge E of Yalobi, on rocky grassy hillside; crushed leaves smell of beans.

\subsection{HERNANDIACEAE}

Hernandia nymphaeifolia (Presl) Kubitzi buevu Widespread on Fiji's coast. St John 18090, "mbuebu". ROG 6283, Yalobi, $8 \mathrm{~m}$ tall tree on sandy low terrace at rear of beach, flrs with a spicy fragrance.

\subsection{HIPPOCRATEACEAE}

Salacia vitiensis A.C. Sm.

Endemic to Fiji, rather uncommon (Waya, Viti Levu, Vanua Levu, Vanua Mbalavu). ROG 6687, SE slopes of Vatunareba, liane in dry forest. $R O G 6868$, loc. cit., in open place in gully forest.

\subsection{ICACINACEAE (APG IV: Cardiopteridaceae)}

\section{Citronella vitiensis R. Howard}

Endemic to Fiji (Waya, Viti Levu, Ovalau, Vanua Levu), perhaps usually in drier forests. ROG 6744, E side of peaks above Waya Levu, $3 \mathrm{~m}$ tall tree in ridge thicket, fruit green to purple.

\subsection{LAMIACEAE}

Leucas decemdentata (Willd.) Sm.

Rather local in Fiji. ROG 6772, Nagwa peaks (E above gardens in valley NW of Yalobi), on rock ledge in the open, not seen elsewhere. Formerly widespread in open dry sites, now losing to competition from more-aggressive weeds (cf. Acalypha lanceolata, Mollugo pentaphylla, Phyllanthus virgatus, and Plectranthus forsteri).

\section{Plectranthus forsteri Benth.}

Uncommon in Fiji. St John 18109, "mbambaranga". ROG 6890, near Vatunareba summit, on rock ledge in open scrub, not seen elsewhere, ripe fruit. Apparently another of Fiji's pre-European weeds; see the preceding entry. Illn: FV t. 47.

\subsection{LAURACEAE}

Cassytha filiformis L. walawala Abundant on Fiji's coast. St John 18097, Wailevu Creek. ROG 6654, Olo stream, in rocky streamside hibiscus scrub. 


\subsection{LAURACEAE}

Litsea vitiana (Meissn.) Benth. \& Hook. f.

Endemic to Fiji (Waya and the three largest islands, and others). St John 18054, "tarutaru ni lolo". ROG 6497, slope W of Yalobi, $15 \mathrm{~m}$ tall $30 \mathrm{~cm}$ dbh, rare in forest of rocky gully. $R O G 6839$, high point NE of Olo stream, 8 $\mathrm{m}$ tall $25 \mathrm{~cm} \mathrm{dbh}$, in open forest of ridge crest.

Illn: FV t. 50, as Tetranthera vitiana.

\subsection{LEEACEAE}

\section{Leea indica (Burm. f.) Merr.}

Widespread in Fiji. ROG 6751, peaks above Waya

Levu, uncommon in open forest on talus.

\subsection{LEGUMINOSAE}

Abrus precatorius L.

lele

Widespread on Fiji's coast. St John 18030. ROG 6400, near Waya Levu village, occ. in streamside scrub.

\section{Acacia simplex (Sparrman) Pedley \\ Widespread on Fiji's coast. ROG 11295, above \\ Vunasinu Point (between village and Olo stream mouth), several trees in secondary forest on dry slope.}

\section{Caesalpinia bonduc}

\section{(L.) Roxb. kai lalālau, qalausori}

Widespread in Fiji. ROG 6408, Yalobi, occ. climber in open bush and under Cocos on sand.

\section{Caesalpinia major}

(Medik.) Dandy \& Exell kai lalālau, qalausori Quite widespread in Fiji but apparently not known from Viti Levu. ROG 6446, Naseva Beach, at edge of coastal scrub. $R O G$ 6510, slope SW of Yalobi, occ. in open forest of rocky gully.

\section{Canavalia cathartica Thou.}

Widespread in Fiji's lowland scrub. St John 18078, Wailevu Creek, "wati koori" [wa tikuri].

\section{Canavalia rosea (Sw.) DC.}

rautolu

Widespread on Fiji's coast. ROG 6448, Naseva Beach, in sandy waste at coastal fringe.

\section{Canavalia sericea A. Gray}

Widespread on Fiji's coast. ROG 6814, 11333, Naseva Beach, occ. on sand just above HWM.

Cynometra insularis A.C. Sm. namo

Endemic to Fiji (Waya and five other high islands), in dry forest. St John 18055, "cibicibi". ROG 6349, Nagwa, $12 \mathrm{~m}$ tall $30 \mathrm{~cm}$ dbh, locally common in older forest. $R O G$ 6655, Olo stream, $6 \mathrm{~m}$ tall, in rocky streamside scrub. ROG 6837 , towards high point above Olo stream, in open forest on rocky slope, flrs with a slightly sour odour.
Dendrolobium umbellatum (L.) Benth. seuseutavē Widespread in Fiji, in dry coastal scrub. St John 18086 , "seuseutavei". ROG 6250, Yalobi, $4 \mathrm{~m}$ tall bushes in dryish scrub, common only where goats cannot get to. $R O G$ 6733, towards summit of Vatunareba, treelets in Dodonaea-Decaspermum scrub.

Derris trifoliata Lour. tuva $d u$

Widespread and abundant on Fiji's coast. ROG 6275, Yalobi, common climber in open bush.

Entada phaseoloides (L.) Merr. $\quad$ wā qiri, wā tiqiri Widespread in Fiji. ROG 6387, between Yalobi and Nalauwaki, climber in secondary forest.

\section{Erythrina variegata $\mathrm{L}$.}

rara

Widespread in Fiji's drier coastal forests. St John 18091. Weiner 254, Yalobi. ROG 6316, E of Olo stream, a few trees $12 \mathrm{~m}$ tall $60 \mathrm{~cm}$ dbh in open forest among boulders, small spines of branchlets \pm proximal on growth flushes, fruit ripe. Seemann (FV: 60) noted that the Fijians coordinated the time of planting of the yam Dioscorea alata with the flowering of the rara.

Inocarpus fagifer (Parkinson) Fosberg $i v i$

Anciently cultivated in Fiji, often naturalized near the coast, $R O G$ 11329, rear of mangrove E of Yalobi village, a few out-of-season flrs, scented as violets.

Intsia bijuga (Colebr.) Kuntze vesi, vesi $d \bar{u}$ Widespread and abundant in Fiji's drier coastal forests.

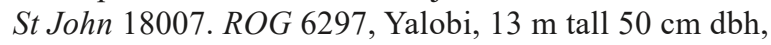
in open bush at foot of hillside.

Illn: USEE 15, Atlas pl. 51, as Afzelia bijuga.

Kingiodendron platycarpum B.L. Burtt namo Endemic to Fiji (Waya and five other high islands). $R O G$ 6532, slope W of Yalobi, towards Naseva beach, $8 \mathrm{~m}$ tall $30 \mathrm{~cm} \mathrm{dbh}$, in forest along bouldery gully, fruit green turning to brown, perhaps nearly ripe. ROG 6722, SE slope of Vatunareba, $10 \mathrm{~m}$ tall $25 \mathrm{~cm} \mathrm{dbh}$, common in open dry forest.

Maniltoa grandiflora (A. Gray) Scheffer namo Widespread in Fiji's drier forests. ROG 6736, SE slope of Vatunareba, $3 \mathrm{~m}$ tall treelet in gully forest. $R O G$ 6746, 6800, E side of peaks above Waya Levu, $3 \mathrm{~m}$ tall, in ridge-crest thicket.

Illn: USEE 15, Atlas pl. 52, as Cynometra grandiflora

\section{Milletia pinnata (L.) Panigrahi}

vesi, vesi wai Widespread in Fiji's coastal forests. St John 18089, "tosinga". ROG 6353, coast E of Olo end of Yalobi, 10 $\mathrm{m}$ tall $40 \mathrm{~cm}$ dbh sprawling tree, fruit ripe. Formerly known as Pongamia pinnata.

Mucuna gigantea (Willd.) DC. kori, tikori Widespread in Fiji's forests. St John 18092, "wa tikoori". ROG 6414, slope above Naseva Beach. ROG 6528, 6529, Olo stream, in Hibiscus tiliaceus scrub, ripe fruit. 


\section{Ormocarpum orientale (Spreng.) Merr.}

Rare on Fiji's dry coasts (Waya, Ovalau, Matuku). ROG 6762, SE slope of Vatunareba, two small treelets in dry open scrub; seen just once elsewhere. The two non-Wayan collections from Fiji are 19th C. ones. The species is also known as $O$. cochinchinense (Lour.) Merr.

\section{Pueraria lobata (Willd.) Ohwi} $a k a$

Widespread in Fiji's dry scrubby hillsides, perhaps after cultivation as a famine-food. ROG 6263, Yalobi, common in dry open places, sometimes initially dominant after grassland fires.

\section{Schleinitzia insularum (Guillemin) Burkart}

Local on Fiji's drier coasts (Waya, Vanua Levu and several other islands). ROG 11326, near S end of Naseva beach, several old trees at one place on coral rock and sand, to $4 \mathrm{~m}$ tall $15 \mathrm{~cm} \mathrm{dbh}$, not regenerating here (the bush frontage being dominated by Leucaena leucocephala).

\section{Serianthes vitiensis}
A. Gray
sē agoago, kaimocemoce

Endemic to Fiji, rare (Waya; two collections from Vanua Levu). ROG 6872, N side of Lekutu, $15 \mathrm{~m}$ tall $80 \mathrm{~cm}$ dbh short-boled tree in forest among rocks. $R O G$ $6810, R O G$ 6825, summit of second peak E of top of gardens in valley NW of Yalobi, in Geissois forest. The related $S$. melanesica is listed as a dry-forest species by Keppel \& Tuiwawa (2007: 563). Fig. 6

Tephrosia purpurea (L.) Pers.

Widespread on Fiji's coast. St John 18137 ,

"rhausenge". ROG 6398, Waya Levu, occ. in gravel berm at beach rear, ripe fruit.

\section{Vigna marina (Burm.) Merr.}

Widespread on Fiji's coast. ROG 6281, Yalobi, at Olo, prostrate vine at beach rear.

\subsection{LOGANIACEAE}

Geniostoma vitiense Gilg \& Benedict buibuitā Widespread and abundant in Fiji's forests. St John 18018, "boiboinda". ROG 6365, Nagwa, $4 \mathrm{~m}$ tall treelet in older secondary forest. $R O G$ 6506, slope $\mathrm{W}$ of Yalobi towards Vatunareba, $8 \mathrm{~m}$ tall $20 \mathrm{~cm}$ dbh, occ. in forest of rocky gully, ripe fruit. ROG 6841, towards high point north of Olo stream, $4 \mathrm{~m}$ tall treelet in open forest, flrs pale green, with a faecal odour.

\subsection{LYTHRACEAE}

\section{Pemphis acidula J.R. \& G. Forst.}

Rather local in Fiji, on coral shores. No specimen is known from Waya, but the species occurs on Viwa I. (ROG obs., July 1991).

\subsection{MALPIGIACEAE}

\section{Hiptage myrtifolia A. Gray}

Endemic to Fiji (Waya, the larger high islands but not Taveuni, and some smaller islands). ROG 6534, slope $\mathrm{W}$ of Yalobi, towards Nasewa Beach, liane to $4 \mathrm{~m}$ high in forest of bouldery gully. ROG 6737, SE slope of Vatunareba, occ. in dry forest. Illn: USEE 15, Atlas pl. 21.

\subsection{MALVACEAE}

Hibiscus tiliaceus $\mathrm{L}$. rea, vau Widespread in Fiji. ROG 6257, Yalobi, shrub $4 \mathrm{~m}$ tall, common throughout the island.

\section{Sida rhombifolia $\mathrm{L}$.}

Widespread in Fiji, a weed of dry open places. ROG 6287, nr Yalobi school, common in grassy waste, ripe fruit.

Thespesia populnea (L.) Solander wiriwiri Widespread in Fiji's coastal forests. ROG 6276, Yalobi, common at beach rear, ripe fruit.

Urena lobata L. qatima Widespread in Fiji in dry open places (an ancient introduction ?), but perhaps declining in frequency. ROG 6426, above Naseva Beach, $1 \mathrm{~m}$ tall singlestemmed bushes, local in open forest, ripe fruit.

\subsection{MELASTOMATACEAE}

Medinilla ovalifolia (A. Gray) A.C. Sm.

Endemic to Fiji (Waya, Viti Levu, Vanua Levu, Ovalau). ROG 6848, E side of peaks above Waya Levu, rare (only two plants seen), epiphytic in low ridge-crest forest.

\section{Memecyclon vitiense A. Gray}

Widespread in Fiji's forests. St John 18044. ROG 6461, slope $\mathrm{W}$ of Yalobi, $3 \mathrm{~m}$ tall $5 \mathrm{~cm}$ dbh, in forest of rocky gully. ROG 6671, in forest high on SE slopes of Vatunareba, locally common.

\subsection{MELIACEAE}

Aglaia vitiensis A.C. Sm.

Endemic to Fiji. St John 18165, “boiboi”. ROG 6703, SE slopes of Vatunareba, $2 \mathrm{~m}$ tall treelet, ripe fruit. $R O G 6685$, loc. cit., occ. in dry light forest at middle and higher altitudes. The Wayan plant belongs to var. minor A.C. Sm., which is known from six of the larger islands.

\section{Dysoxylum mollissimum Miq.}

Widespread, abundant in Fiji's forests. ROG 6429, near peaks $\mathrm{N}$ of valley above Yalobi village's garden valley, $12 \mathrm{~m}$ tall $30 \mathrm{~cm} \mathrm{dbh}$, in forest among boulders. Illn: USEE 15, Atlas pl. 20, as Didymochiton richii. Until recently, known as Dysoxylum richii. 


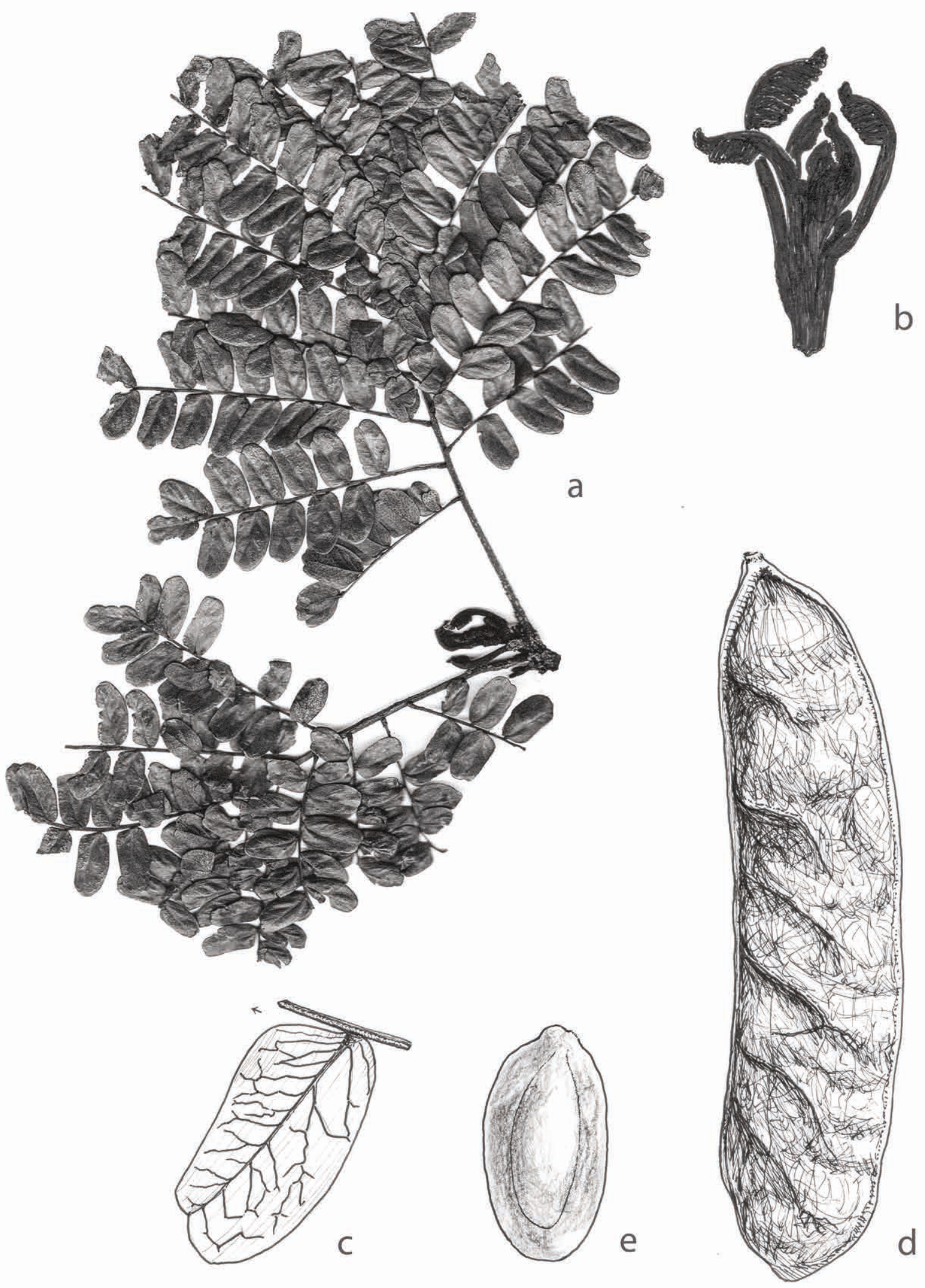

Figure 6. Serianthes vitiensis. a, Leaf [scan, Iflts $1.5 \mathrm{~cm}$ long]; $b$, Shoot apex [photo, image $3 \mathrm{~cm}$ long]; $c$, Leaflet (abaxial), showing prominent nerves [ Iflt $1.5 \mathrm{~cm}$ long]; $d$, Fruit-pod, its seed-bearing edge on left [pod $5 \mathrm{~cm}$ wide]; e, Seed in face view [seed $1.35 \mathrm{~cm}$ long]. a-c from AK 213349, Waya; $d$, e from AK 213395,Waya. 


\section{Dysoxylum seemannii Gillespie}

Endemic to Fiji, apparently widespread in drier forests. $R O G$ 6310, Olo stream, $2 \mathrm{~m}$ tall, occ. among rocks in relic forest, cut bark without odour. ROG 6701, S side of Vatunareba, $3 \mathrm{~m}$ tall, local in forest of old talus slope, near-ripe fruit. $R O G 6821$, loc. cit.

\section{Vavaea amicorum Benth.}

Widespread in Fiji's forests. ROG 6457, $5 \mathrm{~m}$ tall $10 \mathrm{~cm}$ $\mathrm{dbh}$, in forest of rocky gully. ROG 6679, SE slopes of Vatunareba, occ. in dry light forest, ripe fruit. This fruit is said to be the favorite food of the Fijian crested iguana (Morrison et al. 2009). Illn: USEE 15, Atlas pl. 16 B.

\section{Xylocarpus granatum Koenig leqileqi \\ Widespread on Fiji's coast. ROG 6286, Yalobi, at the Olo stream lagoon, $3 \mathrm{~m}$ tall, infrequent.}

\subsection{MOLLUGINACEAE}

\section{Mollugo pentaphylla $\mathrm{L}$.}

Uncommon (an ancient introduction ?) in Fiji in dry places; ROG 6729, SE slopes of Vatunareba, on shallow soil on lava.Other than this Wayan record only one 20th C. collection, from Viti Levu, seems to have been made of this plant.

\subsection{MORACEAE}

Ficus barclayana (Miq.) Summerhayes masimasi Endemic to Fiji (Waya, the three largest islands, and elsewhere). St John 18096, “masimasi”. ROG 6381, Yalobi, $2.5 \mathrm{~m}$ tall treelet in scrub at foot of hillside, hacked-about to provide goat fodder. ROG 6384, Yalobi to Nalauwaki track, in scrub at stream S of Koroimatalevu peak (high point $\mathrm{S}$ of Lekutu), $4 \mathrm{~m}$ tall, ripe fruit. $R O G$ 11298, -9, Yalobi to Natawa track, common in degraded tall coastal forest. ROG 6658, Olo stream, $2.5 \mathrm{~m}$ tall $5 \mathrm{~cm} \mathrm{dbh}$, in dry streamside forest, the figs soft, white, with wasps exiting apically. $R O G$ 6807, peaks E above top of Yalobi's garden-valley, $4 \mathrm{~m}$ tall tree in scrub on steep slope, the figs ripe, dark and soft, with seeds. Illn: FV t. 66, as F. barclayi.

\section{Ficus masonii Horne ex Baker}

Endemic to Fiji (Waya, the three largest islands, and elsewhere). St John 18040, Naruarua Gulch, "masimasi". ROG 6767, Viwa I., $4 \mathrm{~m}$ tall $10 \mathrm{~cm}$ dbh tree in garden; supposedly brought from Likuliku on Waya I., to provide a famine food.

Ficus obliqua G. Forst.

Widespread in Fiji's drier forests. St John 18037, "bak". ROG 6415, rocky slope above Naseva, $12 \mathrm{~m}$ tall banyan, ripe fruit. The record of $F$. prolixa from Waya (Gardner \& Pawley 2006: 99) is probably based on a sighting of $F$. obliqua; no Wayan specimen of $F$. prolixa is known, and the species is infrequent in Fiji. Illn: FV t. 68, excl. fig. 8, which is Ficus prolixa (FVN 2: 174).
Ficus pritchardii Seem.

$a a w a$

Endemic to Fiji, abundant on many of the larger islands. St John 18013, "kamba". ROG 6716, towards high point NE of Olo stream, $8 \mathrm{~m}$ tall, $15 \mathrm{~cm}$ dbh. $R O G$ 6757 , peaks $\mathrm{E}$ above gardens in valley NW of Yalobi, $10 \mathrm{~m}$ tall $20 \mathrm{~cm}$ dbh, common in forest with Dillenia and Geissois, figs turning from greenish pink to red and soft and wasps in them now escaping through apex. Illn: FV t. 70.

Ficus tinctoria G. Forst. $a a w a$

Widespread in Fiji's coastal forests. St John 18041, Naruarua Gulch, "mbaka”. ROG 6493, slope W of Yalobi, $4 \mathrm{~m}$ tall tree in forest of rocky gully, uncommon. Illn: FV t. 63.

Ficus vitiensis Seem.

$k a b a$

Endemic to Fiji, widespread and often abundant. $R O G$ 6270 , Yalobi, above the Sayaba compound, $4 \mathrm{~m}$ tall 10 $\mathrm{cm}$ dbh tree on dry hillside.

Trophis scandens (Lour.) Hook. \& Arn. wata Rather local in Fiji (Waya, Mamanuca Is., the three largest islands). ROG 6462, slope $\mathrm{W}$ of Yalobi, brittlestemmed liane in forest of rocky gully. Formerly known as Malaisia scandens.

\subsection{MYRISTICACEAE}

\section{Myristica chartacea Gillespie}

kaidam

Endemic to Fiji (Waya, the two largest high islands and several others). ROG 6496, slope $\mathrm{W}$ of Yalobi, single $6 \mathrm{~m}$ tall tree in forest of rocky gully, ripe fruit. $R O G$ 6698, SE slopes of Vatunareba, uncommon in mid-altitude gully forest.

\subsection{MYRSINACEAE (APG IV Primulaceae)}

\section{Embelia deivanuae R.O. Gardner}

Endemic to Fiji, so far known only from Waya (Gardner 1997: 487). ROG 6811, on the peak east above top of Yalobi village gardens. Not rediscovered in 2017.

Maesa persicifolia A. Gray butabuta

Endemic to Fiji (Yasawa Is., Viti Levu and Vanua Levu). St John 18010. ROG 6249, Yalobi, $2 \mathrm{~m}$ tall, common in dry scrub, ripe fruit. ROG 6504, slope $\mathrm{W}$ of Yalobi, towards Vatunareba, $2 \mathrm{~m}$ tall, in open forest, ripe fruit. $R O G 6656$, Olo stream, $1 \mathrm{~m}$ tall shrub on scrubby dry slope.

\section{Myrsine myricifolia A. Gray}

Widespread and abundant in Fiji's forests. St John 18159, "becebece". ROG 6439, towards the peaks $\mathrm{N}$ of Yalobi above the village's gardens, rare, rock cliffs. $R O G$ 6670, SE slopes of Vatunareba, locally common in dry forest. Sometimes known as Rapanea myricifolia. 


\subsection{MYRTACEAE}

Decaspermum vitiense (A. Gray) Niedenzu nuqa Endemic to Fiji, common in light dry forest. $R O G$ 6469 , Lekutu forest, sprouting from cut $10 \mathrm{~cm} \varnothing$ stump in aqona garden, flrs fragrant. Illn: USEE 15, Atlas pl. 60 B, C, D, as Nelitris vitiensis and N. fruticosa.

Eugenia reinwardtiana (Bl.) DC. $q \bar{e}$ ni koro Abundant on Fiji's coast. ROG 6832, E end of Yalobi coastal frontage, $2 \mathrm{~m}$ tall bushes, local in coastal forest remnant on clay slope. Sometimes known as Jossinia reinwardtiana or Eugenia rariflora. Illn: USEE 15, Atlas pl. 60 A, as E. rariflora.

\section{Metrosideros collina (J.R. \& G. Forst.) A. Gray Widespread in Fiji's rocky forests. St John 18156, "sekula". ROG 6735, SE slope of Vatunareba, $5 \mathrm{~m}$ tall bushes at top of rock face, uncommon. The Wayan plant has been identified as belonging to var. villosa (L.f.) A. Gray, which appears to have the range of the species, excepting Hawaii. Illn: USEE 15, Atlas pl. 68.}

Syzygium corynocarpum (A. Gray) C. Muell. ulalo Widespread in Fiji's forests. St John18043. ROG 6503, slope W of Yalobi towards Vatunareba, $300 \mathrm{~m}, 5 \mathrm{~m}$ tall $10 \mathrm{~cm} \mathrm{dbh}$, local in open forest in gap between the peaks. Illn: USEE 15, Atlas pl. 64, as Eugenia corynocarpa.

\section{Syzygium gillespiei Merr. \& Perry}

Endemic to Fiji (Waya and also, though rather infrequently, on the two largest islands). $R O G 6850$, E side of peaks above Waya Levu, $4 \mathrm{~m}$ tall $5 \mathrm{~cm} \mathrm{dbh}$ treelets, local in ridge-crest thicket.

\section{Syzygium gracilipes (A. Gray) Merr. \& Perry} Endemic to Fiji, as a widespread forest-understorey tree, St John 18172, Olo Creek, "naaaloalo [na aloalo]”. Illn: FV t. 15, as Eugenia gracilipes.

\section{Syzygium malaccense (L.) Merr. \& Perry kavika} Anciently cultivated in Fiji. St John 18124.

\section{Syzygium neurocalyx}

\section{(A. Gray) Christophersen}

Widespread in Fiji's forests, and often cultivated for its scented fruit. ROG 6464, Yalobi, $2 \mathrm{~m}$ tall tree by main entrance to chief's bure. Illn: USEE 15, Atlas pl. 59, as Eugenia neurocalyx.

\section{Syzygium richii}

\section{(A. Gray) Merrill \& Perry}

dakadaka

Widespread in Fiji's coastal forests. ROG 6779, Olo, old $4 \mathrm{~m}$ tall tree on beach frontage; also $\mathrm{nr}$ mangrove here, otherwise not seen on island. Illn: USEE 15, Atlas pl. 58, as Eugenia richii.
Syzygium rubescens (A. Gray) C. Muell.

Endemic to Fiji (Waya, the two largest islands, and Ovalau). ROG 6459, slope $\mathrm{W}$ of Yalobi, $7 \mathrm{~m}$ tall $40 \mathrm{~cm}$ $\mathrm{dbh}$, in forest of rocky gully. ROG 6477, slope W of Yalobi, $5 \mathrm{~m}$ tall $20 \mathrm{~cm}$ dbh, in rocky gully forest. Listed as a dry-zone forest species by Keppel \& Tuiwawa (2007: 560).

Illn: USEE 15, Atlas pl. 63, as Eugenia rubescens.

Syzygium seemannianum Merr. \& Perry asiasi Endemic to Fiji (Waya and five other high islands); a rheophyte, often abundant in its streamside habitat. ROG 6308, 6667, 6870 [with ripe fruit], above Olo stream near Yalobi, to c. $10 \mathrm{~m}$ tall $50 \mathrm{~cm}$ dbh, common at forested stream edge among boulders. The suggestion (Gardner \& Pawley 2006: 99) that ROG 6308 might represent $S$. curvistylum is wrong.

\subsection{NYCTAGINACEAE}

\section{Boerhavia glabrata $\mathrm{Bl}$.}

Local on Fiji's coast. ROG 6390, Olo, occasional at rear of sandy beach. The names $B$. diffusa or $B$. repens (in the broadest sense) might apply to this plant.

Pisonia grandis $\mathrm{R}$. Br.

koakoa Local in Fiji 's coastal forests (Waya, Kadavu, Vanua Levu, Nayambo). ROG 6875, top of gardens in valley $\mathrm{NW}$ of Yalobi, a single tree $15 \mathrm{~m}$ tall $80 \mathrm{~cm}$ dbh on rocky slope, trunk stout and cylindrical, with smooth pale bark and rather sappy wood; said to be rare on the island.

\subsection{OLACACEAE}

\section{Ximenia americana $\mathrm{L}$.}

Widespread on Fiji's coast. ROG 6781, rocky coast near Vanuaseva, a single $1 \mathrm{~m}$ tall bush, "soni" given as possible Wayan name.

\subsection{OLEACEAE}

Chionanthus vitiensis (Seem.) A.C. Sm.

Fiji (Waya and four other high islands). ROG 6686, SE slopes of Vatunareba, $4 \mathrm{~m}$ tall, occ. in light dry forest at middle and higher altitudes, fruit nearly ripe.

Jasminum didymum G. Forst.

rautolu Widespread in Fiji, in dry open forest. St John 18036, Naruarua Gulch, "nunganunga"; St John 18103, Nagua, "rautolu". ROG 6808, central peaks above Yalobi village gardens, climber in open fire-damaged forest on dry ridge, uncommon; fruit mostly not quite ripe. The Wayan specimens of St John here have been identified (FVN 4: 127) as Jasminum degeneri Kobuski, a taxon so far known only from Waya and coastal northern Viti Levu. This seems to be just a xerophytic form of $J$. didymum. 


\subsection{PEPEROMIACEAE (APG IV: Piperaceae)}

\section{Peperomia blanda Kunth}

Widespread in Fiji. St John 18108, "tangatanga". ROG 6452, slope W of Yalobi, $20 \mathrm{~cm}$ tall juveniles, rare on shady rocky ledges in forest, only near the sea and where goats cannot get to; no fertile plants seen. The Wayan plants belong to var. floribunda (Miq.) $\mathrm{H}$. Huber, the Old World representative of the species, formerly recognized as $P$. leptostachya Hook. \& Arn. It is said to be distinguished from the typical variety especially by its non-stipitate fruits.

Peperomia lasiostigma C. DC.

Endemic to Fiji; probably found on most of the high islands. St John 18112. ROG 6759, peaks E above gardens in valley NW of Yalobi, local on rocky ledges in open forest. The Wayan plant belongs to the type variety, which is found on numerous other Fijian high islands.

\subsection{PIPERACEAE}

Piper puberulum Benth. aqonaaqona, aqoaqona Widespread in Fiji's forests. St John 18062. ROG 6371, Lekutu, occ. in shady forest, fruit ripe.

Formerly known as Macropiper puberulum. The Wayan plant belongs to what has been recognized as a glabrous form of the species (FVN 2: 68). Illn: FV t. 75.

\subsection{PITTOSPORACEAE}

Pittosporum brackenridgei A. Gray

Rather local in Fiji's drier forests. St John 18145, "tuba". ROG 6699, SE slopes of Vatunareba, $2 \mathrm{~m}$ tall, uncommon in lower-altitude forest. Illn: USEE 15, Atlas pl. 17 A.

\section{Pittosporum rhytidocarpum A. Gray}

Endemic to Fiji, widespread in forest. St John 18050, Naruarua Gulch, “mbau”. Illn: USEE 15, Atlas pl. 18.

\subsection{PORTULACACEAE}

\section{Portulaca samoensis Poelln.}

Rather local on Fiji's coast (Waya, the two largest islands and several others). St John 18152, Nakawa Gulch, "ndomindomi".

\subsection{RHAMNACEAE}

\section{Alphitonia franguloides A. Gray}

Endemic to Fiji, widespread and often abundant in forest. St John 18116, "ndoi ndra". ROG 6518, $4 \mathrm{~m}$ tall $25 \mathrm{~cm}$ dbh crooked-trunked tree in scrub, especially the branchlets smelling of oil-of-wintergreen. Illn: USEE 15, Atlas pl. 22 B.

Alphitonia zizyphoides (Spreng.) A. Gray doi Widespread and often abundant in Fiji's forests. St John 18019, Olo Creek, N of Yalobi, “ndoi ndu". Illn: USEE 15, Atlas pl. 22 A.
Colubrina asiatica (L.) Brongn. $k \bar{a}$ vere, vere Widespread on Fiji's coast. St John 18031, "sili". ROG 6357 , gardens in valley NW of Yalobi, $3 \mathrm{~m}$ tall bush edge treelet, ripe fruit. $R O G$ 6463, Yalobi, $2 \mathrm{~m}$ tall scandent plant at lagoon edge.

Rhamnella vitiensis (Benth.) A.C. Sm. wata Local in Fiji (mostly the high islands). ROG 6404, Waya Levu gardens, shrub in regrowth.

\section{Smythea lanceata (Tul.) Summerhayes}

Uncommon in Fiji (Waya and the two largest islands), in dry open scrub. $D A 13670$, Yalobi.

Illn: FV t. 14, as Smythea pacifica.

\section{Ventilago vitiensis A. Gray}

Quite widespread in Fiji. St John 18105, "wawa". $R O G$ 6322, gardens in valley NW of Yalobi, common in forest on bouldery slope. ROG 6694, SE slopes of Vatunareba, in dry forest.

\subsection{RHIZOPHORACEAE}

Bruguiera gymnorrhiza (L.) Lam. lailai Widespread in Fiji's mangrove. ROG 6277, Yalobi, 6 m tall, at lagoon edge.

Rhizophora stylosa Griffith tiritiri Widespread in Fiji's mangrove. ROG 6409, Yalobi, to c. $6 \mathrm{~m}$ tall, dominant at lagoon edge.

\subsection{RUBIACEAE}

\section{Antirhea inconspicua (Seem.) Christophersen}

Widespread in Fiji's dry coastal forests. ROG 6431, towards the peaks $\mathrm{N}$ of Yalobi, in forest among boulders. ROG 6721 , SE slopes of Vatunareba, occ. in dry open forest, ripe fruit.

\section{Badusa corymbifera (G. Forst.) A. Gray}

Widespread in Fiji's dry rocky forests, often on limestone (but not so on Waya). St John 18099, "tarutaru nikora[ni koro]". St John 18133. St John 18163, “tarutaru”. ROG 6708 , towards high point NE of Olo stream, $2 \mathrm{~m}$ tall shrub, local in forest, flrs scentless by day.

Dolicholobium oblongifolium A. Gray

Endemic to Fiji, widespread and abudant in light forest on the high islands. $R O G 6798$, E side of peaks above Waya Levu, $3 \mathrm{~m}$ tall bushy trees, local in forest towards ridge crest.

\section{Gardenia grievei Horne ex Baker}

Endemic to Fiji, known just from Waya and Vanua Levu. ROG 6478, slope W of Yalobi, $2.5 \mathrm{~m}$ tall $5 \mathrm{~cm}$ $\mathrm{dbh}$, uncommon in forest of rocky gully. $R O G 6680, \mathrm{SE}$ slopes of Vatunareba, $2.5 \mathrm{~m}$ tall, local in light dry forest.

Guettarda speciosa L. buatoka

Widespread on Fiji's coast. ROG 6284, Yalobi, by the school, $4 \mathrm{~m}$ tall, on sandy beach rear. $R O G 6828$, beach at Olo stream mouth, common at scrub edge, to c. $8 \mathrm{~m}$ tall. 


\section{Guettarda wayaensis R.O. Gardner}

Endemic to Fiji. ROG 6498, slope $\mathrm{W}$ of Yalobi, $6 \mathrm{~m}$ tall $10 \mathrm{~cm} \mathrm{dbh}$, occ. in forest of rocky gully. ROG 6700, SE slopes of Vatunareba, local in low-altitude forest, to 12 $\mathrm{m}$ tall $20 \mathrm{~cm} \mathrm{dbh}$, old fruit on ground. Not relocated in 2017. Described from Waya, and subsequently reported from westernmost Vanua Levu (Keppel \& Tuiwawa 2007: 463). Resembles a hybrid between Antirhea inconspicua and Guettarda speciosa.

\section{Hedyotis lapeyrousii DC.}

Widespread in Fiji's disturbed forests. ROG 6344, Nagwa, on clay bank above stream in secondary forest, rare, apparently without a Wayan name. Sometimes considered conspecific with the Asian taxon H. auricularia.

\section{Ixora vitiensis A. Gray}

Endemic to Fiji, known from five islands. St John 18047, "rauyangili". St John 18118. St John 18140, "rautolu". $R O G$ 6330, valley NW of Yalobi, 2 m tall treelets, occ. in forest among boulders. $R O G 11318, \mathrm{~W}$ above grassy mid-part of Olo stream, common on rock outcrops.

\section{Mastixiodendron flavidum (Seem.) A.C. Sm.} Endemic to Fiji (Waya, the two largest islands, and Rabi). ROG 6501, slope $\mathrm{W}$ of Yalobi village, towards Vatunareba, local in open forest, ripe fruit. ROG 6507, loc. cit., $3 \mathrm{~m}$ tall, uncommon in forest of rocky gully.

\section{Morinda citrifolia $\mathrm{L}$.}

kura

Widespread in Fiji's coastal forests.

$R O G$ 6442, Naseva beach, $3 \mathrm{~m}$ tall trees in scrub, fruit nearly ripe (yellow but firm).

\section{Morinda myrtifolia A. Gray}

wata

Widespread in Fiji's drier forests and scrub. ROG 6483, W above Nagwa, on rocky slope, fruit hard, purple.

\section{Mussaenda raiateensis J.W. Moore}

bobo

Widespread in Fiji, in open forest and regrowth. $D A$ 13674, below Yalobi and Natawa. ROG 6379, Yalobi, brought from bush and cultivated at one house.

\section{Ophiorrhiza laxa A. Gray}

Endemic to Fiji, common and widespread in mesic forests. St John 18126 [type of O. leptantha var. yasawana Fosberg], "karaua". ROG 6786, towards summit of Vatunareba, $40 \mathrm{~cm}$ tall, uncommon in gully forest. $R O G$ 6852, E side of peaks above Wayalevu, $50 \mathrm{~cm}$ tall, locally common along rocky channel of gully on steep forested slope. See Darwin (1976) for photographs of this species.

\section{Ophiorrhiza peploides A. Gray}

Endemic to Fiji, common in rocky mesic forests. $R O G$ 6783 , towards Vatunareba summit, occ. in uppermost gully forest. ROG 6788, E side of peaks above Waya Levu, $40 \mathrm{~cm}$ tall, locally common in mesic gully forest. See Darwin (1976) for photographs of this species.
Psychotria amoena A.C. Sm.

Endemic to Fiji (Waya and the two largest islands). $R O G$ 6348, Nagwa, treelets to c. $3 \mathrm{~m}$ tall, locally common in older forest. $R O G 6470$, Lekutu, locally common in shady forest; new growth from cut stump in Piper methystichum garden. ROG 6714, high point NE of Olo stream, $2 \mathrm{~m}$ tall, common in forest, ripe fruit. $R O G$ 6816, towards summit of Vatunareba, common in mid- and higher-altitude gully forest, ripe fruit.

\section{Psychotria tephrosantha A. Gray}

Endemic to Fiji, widespread and abundant in the drier forests. ROG 6743, E side of peaks above Waya Levu, juveniles creeping on rocks and bases of tree trunks. ROG 6792, loc. cit., common here, scrambling on lower parts of trees in forest towards ridge crest, ripe fruit.

\section{Psychotria volii R.O. Gardner}

Endemic to Fiji, known only from Waya. ROG 6488, peaks $\mathrm{W}$ above Nagwa, $3 \mathrm{~m}$ tall, along ridge crest. $R O G$ 6500 , slope W of Yalobi, towards Vatunareba, local in open forest. $R O G$ 6727, SE peak of Vatunareba, treelet of light dryish forest. $R O G$ 6754, 6805, 6809, 6860, peaks E above gardens in valley NW of Yalobi, relict tree on dry fire-swept ridge. $R O G 6858$, towards $\mathrm{S}$ peak of Vatunareba, $2 \mathrm{~m}$ tall, in light dry forest. At the time of its description this tree was not seen in abundance anywhere on Waya. Continued firing of the island's hillsides and the presence of goats now seriously threaten its survival.

Psydrax odorata (G. Forst.) A.C. Sm. \& S.P. Darwin Widespread in Fiji, in dry open forest. St John 18101, "bolabatu". ROG 6432, peaks N of Yalobi, 300 m; 3 m tall, in forest among boulders. ROG 6676, SE slopes of Vatunareba, locally common in dry light forest, fruit ripe.

Tarenna sambucina (G. Forst.) Durand ex Drake Widespread in Fiji, in dry forest, mostly near the coast. No specimen known from Waya; sighted by $R O G$ in 1991 on the peak opposite Nagwa.

\subsection{RUTACEAE}

Euodia hortensis J.R. \& G. Forst. $u c i$ Widespread in Fiji, usually just as a village plant. No specimen known from Waya; sighted by $R O G$ at Yalobi village in the 1990s.

\section{Melicope cucullata}

(Gillespie) A.C. Sm. qālaka, rautolu Apparently rather infrequent in Fiji. St John 18034, "rautolu". ROG 6328, gardens in valley NW of Yalobi, $3 \mathrm{~m}$ tall, occ. in relic forest on bouldery slope. $R O G$ 6842 , high point NE of Olo stream, $3 \mathrm{~m}$ tall, common in open forest. $R O G$ 6406, regrowth in Waya Levu gardens, $3 \mathrm{~m}$ tall.

The Wayan plant belongs to var. cucullata, known from Waya and the three largest islands. 


\section{Micromelum minutum}

(G. Forst.) Seem.

madamada

Widespread in Fiji's drier secondary forests. St John 18017, "mandamanda". ROG 6394, Olo stream, 3 m tall treelet at scrub edge.

\subsection{SANTALACEAE}

\section{Santalum yasi Seem.}

In Fiji known from several of the high islands, but not Taveuni. No specimen is known from Waya, but the plant is said to have been cultivated on the island, at least in former times. Said to grow in other parts of Fiji from near sea-level to c. $200 \mathrm{~m}$, in dry or open forest, often in the talasinga, that is, areas of infertile, fire-swept open ground (FVN 3:738). Apparently overlooked by Keppel \& Tuiwawa (2007) in their list of dry-zone forest species. Illn: FV t. 55.

\subsection{SAPINDACEAE}

Arytera brackenridgei (A. Gray) Radlk. marasa Widespread in Fiji's forests. St John 18115, "marasa". ROG 6410, slope above Naseva Beach, 6 m tall 20 $\mathrm{cm} \mathrm{dbh}$, in young forest. $R O G$ 6683, SE slopes of Vatunareba, $3 \mathrm{~m}$ tall, dominant in dry ridge scrub at middle and higher altitudes.

\section{Cupaniopsis leptobotrys (A. Gr.) Radlk.}

Endemic to Fiji (Waya and four other high islands), often abundant in forest. $R O G$ 6795, E side of peaks above Waya Levu, $3 \mathrm{~m}$ tall $3 \mathrm{~cm}$ dbh, locally common at one place on ridge crest.

\section{Dodonaea viscosa (L.) Jacq.} osi Widespread in Fiji on dry grassy hillsides and scrub and open rocky forest. St John 18005.

Dominant of lower E slope of Vatunareba (after many fires ?), to c. $1.5 \mathrm{~m}$ tall $(R O G, 2017)$.

\section{Elattostachys apetala Radlk.} marasa

Widespread in Fiji's forests. St John 18169, "marasa". ROG 6484, W above Nagwa, $12 \mathrm{~m}$ tall $25 \mathrm{~cm}$ dbh tree in forest among boulders. ROG 6728, SE slope of Vatunareba, $10 \mathrm{~m}$ tall smooth-barked tree at edge of gully forest. Formerly known as E. falcata.

Guioa rhoifolia (A. Gray) Radlk.

marasa

Quite widespread in Fiji's forests. St John 18143. ROG 6537 , high point on E side of Olo stream, $5 \mathrm{~m}$ tall, in open forest. ROG 6845, E side of peaks above Waya Levu, $5 \mathrm{~m}$ tall, in open forest towards ridge crest. In a revision of the genus (van Welzen 1989; see also FVN 5: 593) the St John specimen cited above was said to belong to a new species G. punctata van Welzen, endemic to Fiji. But my two collections agree better with $G$. rhoifolia, having relatively small, straight leaflets (blades $7 \mathrm{~cm}$ long or less), with only a single domatium or often, none. The critical petal-scales seem to be very short and carry robust clavate crests, which does not agree with van Welzen's description of G. punctata. Perhaps both species are present on Waya. Neither G. punctata nor G. rhoifolia is noted by Keppel \& Tuiwawa (2007) as characteristic of Fijian dry-zone forests.

Pometia pinnata J.R. \& G. Forst. tawa

Widespread in Fiji, at least as a cultivated plant. No specimen is known from Waya; seen by ROG at Yalobi village in 1990s. Illn: FV t. 10.

\section{Sapindus vitiensis A. Gray} tōsiga

Widespread but local in Fiji's coastal forests (the three largest islands and several others). ROG 6519, mouth of stream at W end of Yalobi, $10 \mathrm{~m}$ tall $30 \mathrm{~cm}$ dbh crooked-trunked tree among rocks, ripe fruit on ground, yellow-brown, with a pleasant odour. $R O G$ 6782, towards head of Yalobi's village gardens, $10 \mathrm{~m}$ tall $30 \mathrm{~cm}$ dbh, occ. in mesic gully-forest. Sometimes regarded as conspecific with $S$. saponaria L., an almost pantropical taxon.

\subsection{SAPOTACEAE}

Burckella richii (A. Gray) Lam bau

Uncommon in Fiji (Waya and one of the Lau Is.). ROG 6324, gardens in valley NW of Yalobi, trees to $15 \mathrm{~m}$ tall $40 \mathrm{~cm}$ dbh, occ. in relict forest, bark grey, regularly rectangular-platy. $R O G$ 6663, E above Olo stream, 12 $\mathrm{m}$ tall $40 \mathrm{~cm} \mathrm{dbh}$, on grassy hillside, sap yellowishcream and hardly sticky. $R O G$ 6867, SE slope of Vatunareba, $10 \mathrm{~m}$ tall $40 \mathrm{~cm}$, locally common in gully forest; bat-gnawed fruit on ground, green, $7.5 \times 5 \mathrm{~cm}$, a thin fleshy layer over spongy tissue. Fig. 7.

\section{Manilkara vitiensis}

(H.J. Lam \& Olden) B. Meeuse bau, bau som Endemic to Fiji, local in rocky coastal forest (Waya, Mamanucas, northern Lau Group). ROG 6689, SE slopes of Vatunareba, $10 \mathrm{~m}$ tall, in gully forest. $R O G$ 6732, loc.cit., windswept $6 \mathrm{~m}$ tall $15 \mathrm{~cm}$ dbh tree on edge of gully forest.

\section{Palaquium fidjiense Pierre ex Dubard} bau

Endemic to Fiji, rather local (Waya, the two largest high islands, and several others).

ROG 6711, high point NE of Olo stream, $10 \mathrm{~m}$ tall, local in forest below summit. ROG 6791, E side of peaks above Waya Levu, $3 \mathrm{~m}$ tall, local near ridge crest, flrs borne just below leaves.

Planchonella garberi Christopherson bau, bau leke Scattered in low- to mid-altitude forest (Waya, Viti Levu, and elsewhere). St John 18168, "tandiri”. $R O G$ 6479, slope W of Yalobi, $5 \mathrm{~m}$ tall $10 \mathrm{~cm}$ dbh tree in forest of rocky gully. $R O G 6725$, SE slopes of Vatunareba, $10 \mathrm{~m}$ tall $15 \mathrm{~cm}$ dbh smooth-barked tree, fruit green but apple-scented, nearly ripe ? 


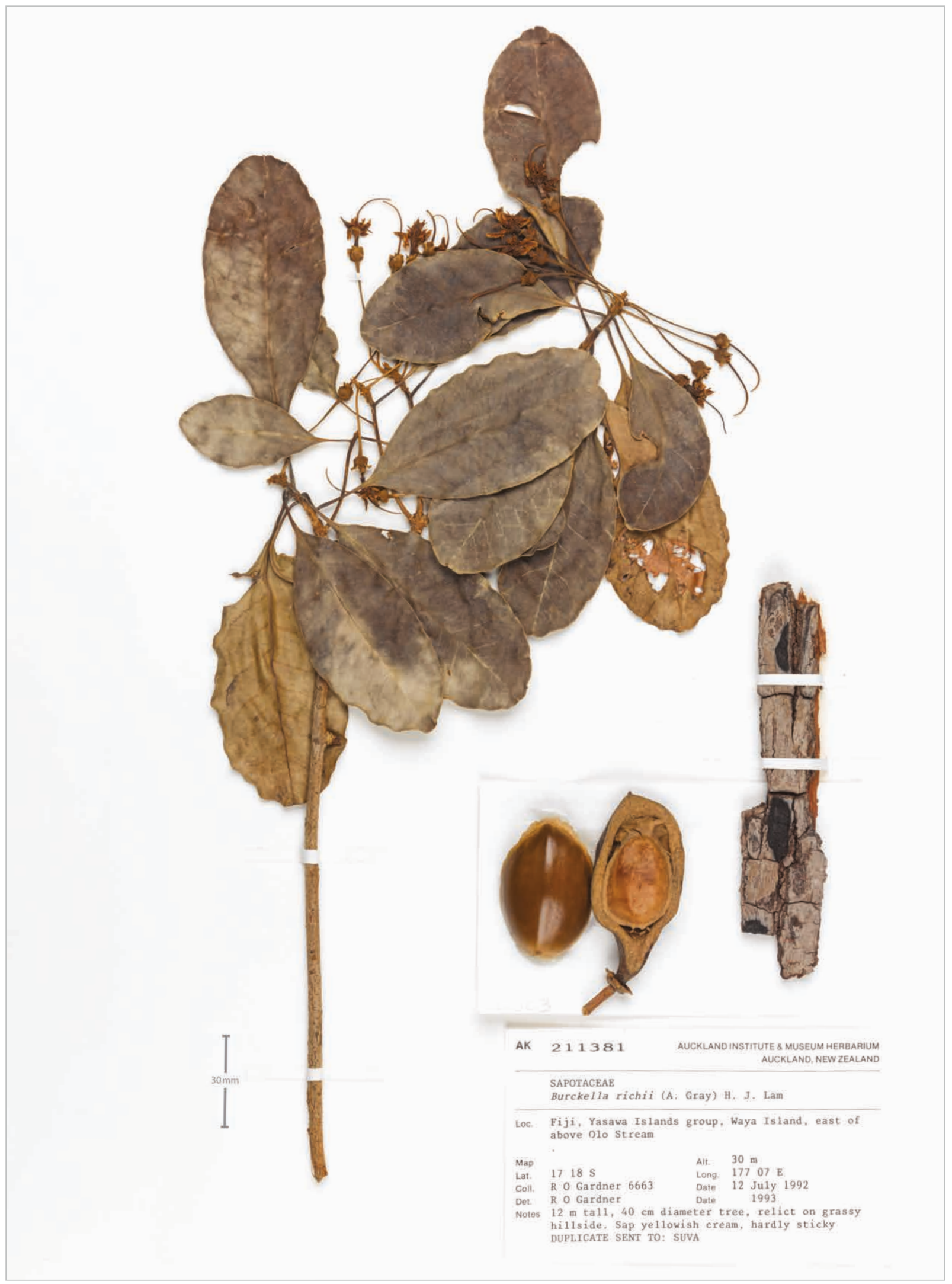

Figure 7. Burckella richii, AK211381. (c) Auckland Museum CC BY. 
Planchonella smithii (van Royen) A.C. Sm. bau Endemic to Fiji (Waya and three largest islands). ROG 6836, high point NE of Olo stream, a single $10 \mathrm{~m}$ tall 25 $\mathrm{cm}$ dbh tree in forest on mesic site (old talus slope), the fruit unripe (?), green under a brown scurf, to $5 \mathrm{~cm} \varnothing$.

\section{Planchonella tahitensis}

(Nadeaud) Pierre ex Dubard bau, bau levu Widespread in Fiji's coastal forests (absent from Viti Levu). $R O G$ 6533, between Yalobi village and Naseva beach, $5 \mathrm{~m}$ tall $15 \mathrm{~cm}$ dbh tree in scrub. ROG 6399, $10 \mathrm{~m}$ tall $30 \mathrm{~cm}$ dbh, bark rough and rectangularly fissured, fruit flattened-globose, glaucous, $3.5 \mathrm{~cm} \varnothing$, nearly ripe. $R O G$ 6450 , Yalobi, at the coast $\mathrm{E}$ past school, $4 \mathrm{~m}$ tall, in coastal forest remnant, flrs not scented. ROG 6726, SE slopes of Vatunareba, $10 \mathrm{~m}$ tall $15 \mathrm{~cm}$ dbh, occ. in dry forest. Formerly known as P. grayana (Swenson et al. 2013).

\subsection{SOLANACEAE}

Solanum americanum Mill. $\quad$ boro dū, boroboro Widespread in Fiji as a village and cultivation weed. No specimen is known from Waya but the species is known from elsewhere in the Yasawa Is.: Weiner 248, Yaqeta I.

\section{Solanum vitiense Seem.}

Quite widespread in Fiji's forests. ROG 6524, Lekutu, $3 \mathrm{~m}$ tall treelets at trackside; seen at only two other places. Illn: FV t. 36.

\subsection{STERCULIACEAE (APG IV: Malvaceae)}

\section{Heritiera littoralis Ait.}

kea ivi na kula

Widespread in Fiji, often abundant at the inland edge of mangrove. St John 18095, "kaenaivinakaka". ROG 6531, Olo stream, sprouts from a cut stump at lagoon edge.

\section{Kleinhovia hospita L.}

Common in Fiji's forests. ROG 6315, E of Olo stream, a few $4 \mathrm{~m}$ tall trees together at edge of forest among boulders; 6718 , loc. cit., several trees to $8 \mathrm{~m}$ tall, not seen elsewhere, said to be "a kind of vau".

Melochia degeneriana A.C. Sm.

vuvudi Endemic to Fiji, quite common on Viti Levu and nearby islands. St John 18009, “pupuinti”. ROG 6268, Yalobi, to c. $4 \mathrm{~m}$ tall. ROG 6361, Yalobi, ridge above Sayaba compound, $3 \mathrm{~m}$ tall $20 \mathrm{~cm}$ dbh treelets, occ. on grassy slope, fruit ripe.

\subsection{THYMELAEACEAE}

Phaleria disperma (G. Forst.) Baill.

tarutaru Widespread in Fiji's coastal forests. ROG 6445, 6780, Naseva Beach, 2-3 m tall shrubs, uncommon on sandy beach frontage.

Phaleria ixoroides Fosb.

tarutaru Endemic to Fiji; known only from drier forests of Waya and Viti Levu. St John 18123 [type of species], small tree $5 \mathrm{~m}$ high, in woods by stream, "tarutaru". ROG 6388, Yalobi to Nalauwaki, stream S of Koroimatalevu peak (high point $\mathrm{S}$ of Lekutu), $1.5 \mathrm{~m}$ tall, seen twice at track edge. ROG 6669, above Olo stream, locally common in streamside forest. ROG 6695, SE slopes of Vatunareba, $2 \mathrm{~m}$ tall bush in dry forest.

\section{Phaleria lanceolata (A. Gray) Gilg}

Endemic to Fiji; known only from Waya and Vanua Levu. ROG 6723, SE slope of Vatunareba, a few $2 \mathrm{~m}$ tall bushes in dry open forest, ripe fruit red, oblong, 1.6 $x 1.2 \mathrm{~cm}$. Presumably recognized by the Wayans as a kind of tarutaru. The identification is a tentative one; the relatively small size (c. $8 \mathrm{~cm}$ long and $2.5 \mathrm{~cm}$ wide) of the leaves of $R O G 6723$ and the lack of persistent involucral bracts, would, according to Smith (FVN 2: 581), rule out $P$. glabra (Turrill) Domke but not $P$. acuminata (A. Gray) Gilg.

Wikstroemia coriacea Seem.

mudu

Widespread in Fiji's drier forests. St John 18006. ROG 6323 , gardens in valley NW of Yalobi, $2 \mathrm{~m}$ tall treelet in light forest, ripe fruit. The name $W$. foetida (L.f.) A. Gray has been commonly used for this species.

\subsection{TILIACEAE (APG IV: Malvaceae)}

\section{Grewia crenata}

(J.R. \& G. Forst.) Schinz \& Guillaumin nice Widespread in Fiji's open, rather dry coastal forests. St John 18150. ROG 6374, Lekutu, $2 \mathrm{~m}$ tall, occ. in shady places.

\section{Trichospermum richii (A. Gray) Seem.}

Widespread in forest of Fiji's larger islands. ROG 6706, towards high point $\mathrm{N}$ of Olo stream, $3 \mathrm{~m}$ tall, local on forest margin. The usual Fijian name mako for this distinctive tree is probably used on Waya. Illn: USEE 15, Atlas pl. 14, as Diclidocarpus richii.

* Triumfetta rhomboidea Jacq. qatima

Widespread and often abundant in Fiji, often on open scrubby hillsides, etc. ROG 6256, Yalobi, $1 \mathrm{~m}$ tall, common weed here and throughout island, ripe fruit.

\subsection{ULMACEAE (APG IV: Cannabaceae)}

Parasponia andersonii (Planch.) Planch. drou Widespread in Fiji, a forest pioneer. DA 13673, below Yalobi and Natawa. ROG 6299, Yalobi village, $3 \mathrm{~m}$ tall, among grass on dry slope.

\section{Trema cannabina Lour.}

Widespread in Fiji, a forest pioneer. ROG 6705, towards high point NE of Olo stream; $3 \mathrm{~m}$ tall, local on forest edge, ripe fruit, "rome alewa". $R O G$ 11296,above Vunasinu Point (between village and Olo stream mouth), uncommon in dry scrub. This species is much less common on Waya than the very similarlooking Parasponia andersonii. There appears to be no well-attested, contrastive Wayan name for it. 


\subsection{URTICACEAE}

Boehmeria virgata (G. Forst.) Guillemin rōmē Local in Fiji's drier forests (Waya, the three larger islands, and others). ROG 6797, E side of peaks above Waya Levu, at one place in open mesic forest on talus.

\section{Cypholophus heterophyllus (Wedd.) Wedd.}

Widespread in Fiji's forests. St John 18076. ROG 6383, 6386 , stream S of Koroimatalevu peak (high point S of Lekutu), to $1.5 \mathrm{~m}$ tall, local in scrub about the gardens of Nalauwaki village.

Illn: FV t. 62, as Boehmeria harveyi.

Dendrocnide harveyi (Seem.) Chew salato

Widespread in Fiji's forests (Waya, the three larger islands, and others). $R O G$ 6416, slope above Naseva beach, $10 \mathrm{~m}$ tall $80 \mathrm{~cm}$ basal $\varnothing$ trees at foot of cliff below peaks. ROG 6512, slope on NW side of Vatunareba peak, to $12 \mathrm{~m}$ tall, common on good soil of old talus slope.

Illn: FV t. 59, as Laportea harveyi.

Leucosyke corymbulosa (Wedd.) Wedd. rōme Widespread in Fiji's forests and scrub, mostly near the coast. St John 18065, "kalakuro". ROG 6255, Yalobi, $3 \mathrm{~m}$ tall shrub in dryish scrub, ripe fruit mucilaginous, slightly sweet and bitter.

\section{Pipturus argenteus}

\section{(G. Forst.) Wedd.}

rōmē, rōmē kavukavu

In Fiji known mainly from drier forests of Viti Levu. St John 18077. ROG 6428, gardens in valley NW of Yalobi, $2.5 \mathrm{~m}$ tall treelet in grassy scrub. ROG 6662, E above Olo stream, $2 \mathrm{~m}$ tall bush on rock face. $R O G$ 6752, E side peak above Waya Levu, occ. in open forest, ripe fruit.

Procris pedunculata (J.R. \& G. Forst.) Wedd. Widespread in Fiji in rocky forests. No specimen is known from Waya. Sighted by ROG 22 July 1992, east from central peaks towards Lekutu, a colony in rock crevice in light shade.

\subsection{VERBENACEAE (APG IV: Lamiaceae)}

Clerodendrum inerme (L.) Gaertn. aria, ria Widespread and abundant on Fiji's coasts. ROG 6397, Waya Levu village, sprawling $2 \mathrm{~m}$ tall shrub on coral gravel berm at beach rear.

Premna protrusa A.C. Sm. \& S. Darwin araro Endemic to Fiji, widespread in coastal and inland places. $D A$ 13671, below Yalobi and Natawa. $R O G$ 6690 , SE slopes of Vatunareba, $8 \mathrm{~m}$ tall $25 \mathrm{~cm} \mathrm{dbh}$, occ. in dry forest, ripe fruit.

Illn: FV t. 43, as P. taitensis [except for a detached branchlet at lower left, which belongs to P. serratifolia; FVN 5: 192].
Premna serratifolia $\mathrm{L}$.

araro Widespread in Fiji's coastal forests. St John 18136. DA 13669, Yalobi. ROG 6298, Yalobi, $4 \mathrm{~m}$ tall $10 \mathrm{~cm} \mathrm{dbh}$ bushes on dry grassy hillside. See under P. protrusa for reference to FV t. 43.

Vitex trifolia $\mathrm{L}$. drala

Common in Fiji, usually at or near the coast. $R O G$ 6301, Yalobi, ridge above Sayaba compound, prostrate bushes, common among rocks on dry grassy slope, not eaten by goats. ROG 6354, coast E of Olo end of Yalobi, $3 \mathrm{~m}$ tall treelet behind beach. Some of the Wayan plants (e.g., ROG 6301) belong to var. subtrisecta, whose leaves usually have three leaflets; the type variety (e.g., $R O G$ 6354) has three to five.

\subsection{VIOLACEAE}

\section{Agatea violaris A. Gray}

Widespread in Fiji's forests. ROG 6822, SE side of range above track between Yalobi and Waya Levu, scandent in light forest on ridge. Illn: USEE 15, Atlas pl. 7.

\section{Rinorea benghalensis (Wall.) Kuntze}

In Fiji known only from Waya (Gardner 1997). ROG 6494, slope W of Yalobi, towards Vatunareba, $2.5 \mathrm{~m}$ tall, local in open forest. ROG 6701, E slopes of Vatunareba, $3 \mathrm{~m}$ tall, locally common in mid- and higher-altitude gully forest, not seen on other peaks of Waya. An earlier record of $R$. benghalensis for Fiji (Ovalau) is wrong, being based on a specimen of Casearia richii (FVN 2: 644).

\subsection{VITACEAE}

Tetrastigma vitiense (A. Gray) A.C. Sm.

Endemic to Fiji (Waya and several of the higher islands). $R O G$ 6799, 6846, E side of peaks above Waya Levu, occ. in open ridge thickets.

\section{ACKNOWLEDGEMENTS}

I am grateful for the help I have had from the Botany Department (AK) of the Auckland War Memorial Museum, whose Curator, Ewen Cameron, and Collections Manager, Dhahara Ranatunga, encouraged this project and attended to all biosecurity and curatorial matters.

Barbara Parris, Bill Sykes, Jan-Frits Veldkamp, Dick Watling and Art Whistler advised on taxonomic and ecological problems. Roger Munn was a good companion on my 2017 trip.

I first went to Waya with Andrew Pawley of the Australian National University, who has been studying all aspects of "the words of Waya" since the 1960s; consequently, I was readily given permission by the Tui Waya of the time, Ratu Nalotonidave Naivalu, to collect throughout his island. I am also indebted to those Wayans who have shared their plant-knowledge with me, in particular, my two friends at Yalobi, Ms. Adi Kelera Sayaba and Mr. Seremaia Tuicuvu. 


\section{REFERENCES}

Adema, F., 1993. Elattostachys (Blume) Radlk. in Fiji. Pacific Science 47: 295-297.

Angiosperm Phylogeny Group, 2016. An update of the Angiosperm Phylogeny Group classification for the orders and families of flowering plants: APG IV. Botanical Journal of the Linnaean Society 181: 1-20. doi.org/10.1111/boj.12385

Brackenridge, W.D., 1855. United States Exploring Expedition 1838-1842. Vol. 16 Cryptogamia: Filices. Atlas. C. Sherman, Philadelphia.

Brownlie, G., 1977. The Pteridophyte Flora of Fiji. Vaduz: J. Cramer.

Brownsey, P.J. and L.R. Perrie, 2011. A revised check-list of Fijian ferns and lycophytes. Telopea 13: 513-562.

Chen C.W., L. Perrie, D. Glenny, and W.L. Chiou, 2017. Sol Amazing: Lycophytes and Ferns of the Solomon Islands. Taichung: National Museum of Natural Science.

Clayton, W.D. and N. Snow, 2010. A Key to Pacific Grasses. Kew: Royal Botanic Gardens.

Darwin, S.P., 1976. The Pacific species of Ophiorrhiza L. (Rubiaceae). Lyonia 1: 47-102.

Derrick, R.A., 1965. The Fiji Islands. 2nd revd edn. Suva: Government Printer.

Forster, P.I., 1992. A taxonomic revision of Sarcolobus (Asclepidaceae: Marsdenieae) in Fiji. Australian Systematic Botany 5: 593-596.

Forster, P.I., 1994. Revision of Euphorbia plumerioides Teijsm. ex Hassk. (Euphorbiaceae) and allies. Austrobaileya 4: 245-264. doi.org/10.1071.5139920593

Gardner, R.O., 1997. New and noteworthy plants from Fiji. New Zealand Journal of Botany 35: 487-492. doi.org/10.1080/0028825X.1987.10410172

Gardner, R. and A. Pawley, 2006. Annotated list of local plant names from Waya Island, Fiji. Records of the Auckland Museum 43: 97-108.

Geraghty, P., 1983. The History of the Fijian Languages. University of Hawaii Press.

Gillespie, T.W. and T. Jaffré, 2003. Tropical dry forest in New Caledonia. Biodiversity and Conservation 12: 1687-1697.

Gray, A., 1854. United States Exploring Expedition 1838-1842. vol. 15. Phanerogamia. Vol. 1. Philadelphia: C. Sherman.

Gray, A., 1856. United States Exploring Expedition 1838-1842. vol. 15. Phanerogamia, Atlas. Philadelphia, C. Sherman.

Henderson, C.P \& I.R. Hancock, 1988. A Guide to the Useful Plants of the Solomon Islands. Honiara: Ministry of Agriculture \& Lands.
Holttum, R.E., 1964. The tree-ferns of the genus Cyathea in Australasia and the Pacific. Blumea 12: 241-274.

Hopkins, H.F. and I.J. Menzies, 1995. The Flora of Motupore Island. Port Moresby, UPNG.

Hovenkamp P.H. and F. Miyamoto, 2005. A conspectus of the native and naturalized species of Nephrolepis (Nephrolepidaceae) in the world. Blumea 50: 279-322.

Hunt, T., K. Aronsen, E. Cochrane, J. Field, L. Humphrey and T. Reith, 1999. A preliminary report on archaeological research in the Yasawa Islands, Fiji. Domodomo 12: 5-43.

Keppel, G. and M.W. Tuiwawa, 2007. Dry zone forests of Fiji: species composition, life history traits, and conservation. New Zealand Journal of Botany 45: 545-563. doi.org/10.1080/0028825079509738

Laubenfels, D. J. de and F. Adema, 1998. A taxonomic revision of the genera Cycas and Epicycas gen. nov. (Cycadaceae). Blumea 43: 351-400.

Morrison, C., G. Keppel, N. Thomas, I. Rounds, and P.S. Harlow, 2009. Critically Endangered Fijian Crested Iguana (Brachylophus vitiensis) shows habitat preference for globally threatened tropical dry forest. Pacific Science 63: 223-242. doi.org/10.2984.049.063.0205

Middleton, D.J., 2002. Revision of Alyxia (Apocynaceae). Part 2: Pacific Islands and Australia. Blumea 47: 1-93.

Mueller-Dombois, D. and F.R. Fosberg, 1998. Vegetation of the Tropical Pacific Islands. Springer.

Nakamura, T. and S. Matsumoto (eds), 2008. Illustrated Flora of Ferns and Fern Allies of South Pacific Islands. Tokyo, Tokai University Press.

Orchard, A.E. and P.M. McCarthy (eds), 1998. Flora of Australia. Vol. 48. ABRS/CSIRO.

Peekel, G., 1984. Flora of the Bismarck Archipelago for Naturalists. Lae, Office of Forests.

Seemann, B., 1865-1873. Flora Vitiensis. London, L. Reeve \& Co.

Smith, A.C., 1979-1991. Flora Vitiensis Nova. Vols 1-5 [1979, 1981, 1985, 1988, 1991; also Comprehensive Indices, 1996. Hawaii, Pacific Tropical Botanical Gardens.

Swenson, U., S. Nylinder, and J. Munzinger, 2013. Towards a natural classification of Sapotaceae in Oceania and Southeast Asia. Taxon 62: 746-770. doi.org/10.12705/624.11

Twyford, I.T. and A.C.S. Wright, 1967. The Soil Resources of the Fiji Islands. Suva: Government of Fiji.

Welzen, P. van, 1989. Guioa Cav.; taxonomy, phylogeny and historical biogeography. Leiden Botanical Series 12: $1-314$. 
APPENDIX 1: Summary list.

$\mathbf{e}=$ species endemic to Fiji

* = may not be indigenous to Fiji

\section{Ferns and lycophytes}

\section{ASPLENIACEAE}

Asplenium amboinense Willd.

Asplenium polyodon $\mathrm{G}$. Forst.

BLECHNACEAE

Blechnum orientale $\mathrm{L}$.

CYATHEACEAE

Cyathea lunulata (G. Forst.) Copel.

DAVALLIACEAE

Davallia heterophylla Sm.

Davallia solida (G. Forst.) Sw.

DENNSTAEDTIACEAE

Microlepia speluncae (L.) T. Moore

Pteridium esculentum (G. Forst.) Cockayne

DICKSONIACEAE

Calochlaena straminea (Labill.) M.D. Turner \& R.A. White DRYOPTERIDACEAE

e Polystichum pilosum Copel.

GLEICHENIACEAE

Dicranopteris linearis (Burm.f.) Underw.

HYMENOPHYLLACEAE

Trichomanes atrovirens (C. Presl) Kunze

LOMARIOPSIDACEAE

Nephrolepis hirsutula (G. Forst.) C. Presl

LYCOPODIACEAE

Lycopodiella cernua (L.) Pic.Serm.

LYGODIACEAE

Lygodium reticulatum Schkuhr

MARATTIACEAE

Angiopteris evecta (G. Forst.) Hoffm.

POLYPODIACEAE

Drynaria rigidula (Sw.) Bedd.

Microsorum grossum (Langsd. \& Fisch.) S.B. Andrews

e Prosaptia vomaensis (Brownlie) Parris

Pyrrosia lanceolata (L.) Farw.

PSILOTACEAE

Psilotum nudum (L.) P. Beauv.

PTERIDACEAE

Acrostichum aureum $\mathrm{L}$.

Adiantum hispidulum Sw.

* Adiantum trapeziforme L.

Antrophyum plantagineum (Cav.) Kaulf.

Cheilanthes nudiuscula (R.Br.) T. Moore

Doryopteris concolor (Langsd. \& Fisch.) Kuhn

Haplopteris elongata (Sw.) E.H. Crane

Pteris tripartita $\mathrm{Sw}$.

* Pteris vittata $\mathrm{L}$.

Taenitis pinnata (J. Sm.) Holttum

SELAGINELLACEAE

Selaginella laxa Spring

Selaginella firmula A. Braun ex Kuhn

Selaginella victoriae T. Moore

SCHIZAEACEAE

Schizaea dichotoma (L.) Sm.

TECTARIACEAE

Tectaria latifolia (G. Forst.) Copel.

THELYPTERIDACEAE

Macrothelypteris torresiana (Gaudich.) Ching

Sphaerostephanos invisus (G. Forst.) Holttum

\section{Gymnosperm}

\author{
CYCADACEAE \\ Cycas celebica Miq.
}

\section{Monocotyledons}

AGAVACEAE

* Cordyline fruticosa (L.) A. Chev

ARACEAE

* Alocasia macrorrhizos (L.) G. Don

* Amorphophallus paeoniifolius (Dennst.) Nicolson

* Cyrtosperma merkusii (Hassk.) Schott

Epipremnum pinnatum (L.) Engl.

ARECACEAE

Cocos nucifera $\mathrm{L}$.

* Pritchardia pacifica Seem. \& H. Wendl. CYMODOCEACEAE

Halodule pinifolia (Miki) den Hartog

Syringodium isoetifolium (Aschers.) Dandy

CYPERACEAE

Carex brunnea Thunb.

Carex dietrichiae Boeck.

Cyperus javanicus Houtt.

Fimbristylis cymosa $\mathrm{R}$. Br.

Fimbristylis dichotoma (Burm. f.) Kern

Fimbristylis ovata (Burm. f.) Kern

Gahnia aspera (R. Br.) Spreng.

Rhynchospora corymbosa (L.) Britton

Scleria lithosperma (L.) Sw.

Scleria polycarpa Boeck.

DIOSCOREACEAE

* Dioscorea bulbifera L.

* Dioscorea pentaphylla L.

HEMEROCALLIDACEAE

Geitonoplesium cymosum (R. Br.) A. Cunn. ex Hook. HYDROCHARITACEAE

Halophila minor (Zoll.) den Hartog

ORCHIDACEAE

Calanthe triplicata (Willemet) Ames

Dendrobium tokai Reichenb. f. ex Seem.

Eulophia pulchra (Thouars) Lindl.

Liparis condylobulbon Rchb. f.

Oberonia equitans (G. Forst.) Mutel

e Pseuderia smithiana C. Schweinf. Spathoglottis pacifica Rchb. f.

Taeniophyllum fasciola (G. Forst.) Seem. PANDANACEAE

Freycinetia urvilleana Hombron \& Jacq.

Pandanus tectorius Sol. ex Parkinson

POACEAE

* Cenchrus polystachios (L.) Morrone

Centotheca lappacea (L.) Desv.

Chrysopogon aciculatus (Retz.) Trin.

* Coix lacryma-jobi L.

* Cymbopogon coloratus (Hook. f.) Stapf

Cymbopogon refractus $\mathrm{R}$. Br.

Cyrtococcum oxyphyllum (Hochst. ex Steudel) Stapf

Digitaria setigera Roth ex Roem. \& Schultes

Heteropogon contortus (L.) P. Beauv. ex Roem. \& Schultes

Imperata conferta (J. Presl) Ohwi

Lepturus repens (G. Forst.) R. Br. 
Miscanthus floridulus (Labill.) Warb. ex K. Schum. \& Lauterb.

Oplismenus compositus (L.) Beauv.

Paspalum scrobiculatum L.

* Schizostachyum glaucifolium (Rupr.) Munro Stenotaphrum micranthum (Desv.) Hubbard Thuarea involuta (Forst. f.) R. Br. ex Sm. SMILACACEAE

Smilax vitiensis (Seem.) A. DC. in DC. TACCACEAE

* Tacca leontopetaloides (L.) Kuntze XANTHORRHOEACEAE

Dianella adenanthera (Forst. f.) R.F. Henderson ZINGIBERACEAE

* Curcuma longa $\mathrm{L}$.

* Zingiber zerumbet (L.) Sm.

\section{Dicotyledons}

\section{ACANTHACEAE}

Graptophyllum insularum (A. Gray) A.C. Sm. AIZOACEAE

Sesuvium portulacastrum (L.) L.

AMARANTHACEAE

* Achyranthes aspera L.

AMARANTHACEAE

Deeringia amaranthoides (Lam.) Merr.

ANACARDIACEAE

Dracontomelon vitiense Engl.

Pleiogynium timoriense (DC.) Leenh.

Rhus taitensis Guillemin

Semecarpus vitiensis (A. Gray) Engler

APIACEAE

Centella asiatica (L.) Urb.

APOCYNACEAE

Alyxia bracteolosa A. Gray

Alyxia stellata (J.R. \& G. Forst.) Roem. \& Schult.

Cerbera manghas $\mathrm{L}$.

Melodinus glaber Turrill

Ochrosia oppositifolia (Lam.) K. Schum.

Ochrosia vitiensis (Markgraf) Pichon

Tabernaemontana pandacaqui Lam.

ARALIACEAE

Polyscias multijuga (A. Gray) Harms

ASCLEPIADACEAE

Hoya autralis $\mathrm{R}$. $\mathrm{Br}$.

e Sarcolobus stenophyllus (A. Gray) P.I. Forst. ASTERACEAE

Wollastonia biflora (L.) DC.

BALANOPHORACEAE

Balanophora fungosa J.R. \& G. Forst.

BARRINGTONIACEAE

Barringtonia asiatica (L.) Kurz

Barringtonia edulis Seem.

BORAGINACEAE

Cordia subcordata Lam.

Heliotropium foertherianum Diane \& Hilger

CAPPARIDACEAE

Capparis cordifolia Lam.

CASUARINACEAE

Casuarina equisetifolia J. R. \& G. Forst.

CELASTRACEAE

e Cassine vitiensis (A.C. Sm.) A.C. Sm.

e Celastrus richii A. Gray

CLUSIACEAE

Calophyllum inophyllum $\mathrm{L}$.

e Calophyllum vitiense Turrill

Garcinia pseudoguttifera Seem.

COMBRETACEAE
Terminalia catappa $\mathrm{L}$.

Terminalia litoralis Seem.

e Terminalia vitiensis A.C. Sm.

CONNARACEAE

e Connarus pickeringii A. Gray

CONVOLVULACEAE

Evolvulus alsinoides (L.) L.

Ipomoea littoralis $\mathrm{B} 1$.

Ipomoea pes-caprae (L.) R. Br.

Merremia peltata (L.) Merr.

Operculina turpethum (L.) A. Silva Manso

CUNONIACEAE

e Geissois ternata A. Gray

e Weinmannia vitiensis Seem.

DICHAPETALACEAE

Dichapetalum vitiense (Seem.) Engl.

DILLENIACEAE

Dillenia biflora (A. Gray) Martelli

EBENACEAE

e Diospyros gillespiei (Fosb.) Kostermans

Diospyros major (Forst. f.) Bakh.

e Diospyros phlebodes (A.C. Sm.) A.C. Sm.

e Diospyros vitiensis Gillespie

EUPHORBIACEAE

Acalypha lanceolata Willd.

Acalypha repanda Muell. Arg.

e Claoxylon echinospermum Muell. Arg.

* Codiaeum variegatum (L.) A.H.L. Juss.

e Croton metallicus Seem.

Croton microtiglium Burkill

Euphorbia plumerioides Teijsm. ex Hassk.

EUPHORBIACEAE ctd

Excoecaria agallocha L.

Glochidion concolor Muell. Arg.

e Glochidion seemannii Muell. Arg.

e Glochidion vitiense (Muell. Arg.) Gillespie

Homalanthus nutans (Forst. f.) Guill.

Macaranga seemannii (Muell. Arg.) Muell. Arg.

Mallotus tiliifolius (B1.) Muell. Arg.

* Phyllanthus virgatus G. Forst.

Stillingia pacifica Muell. Arg.

FLACOURTIACEAE

e Casearia longifolia A.C. Sm.

Erythrospermum acuminatissimum (A. Gray) A.C. Sm.

e Flacourtia subintegra A.C. Sm.

e Homalium vitiense Benth.

Xylosma simulans A.C. Sm.

GESNERIACEAE

e Cyrtandra anthropophagorum Seem.

GOODENIACEAE

Scaevola sericea Vahl

GYROCARPACEAE

Gyrocarpus americanus Jacq.

HERNANDIACEAE

Hernandia nymphaeifolia (Presl) Kubitzi

HIPPOCRATEACEAE

e Salacia vitiensis A.C. Sm.

ICACINACEAE

e Citronella vitiensis R. Howard

LAMIACEAE

Leucas decemdentata (Willd.) Sm.

Plectranthus forsteri Benth.

LAURACEAE

Cassytha filiformis L.

e Litsea vitiana (Meissn.) Benth. \& Hook. f.

LEEACEAE

Leea indica (Burm. f.) Merr.

LEGUMINOSAE

Abrus precatorius L. 
Acacia simplex (Sparrman) Pedley

Caesalpinia bonduc (L.) Roxb.

Caesalpinia major (Medik.) Dandy \& Exell

Canavalia cathartica Thou.

Canavalia rosea (Sw.) DC.

Canavalia sericea A. Gray

e Cynometra insularis A.C. Sm.

Dendrolobium umbellatum (L.) Benth.

Derris trifoliata Lour.

Entada phaseoloides (L.) Merr.

Erythrina variegata $\mathrm{L}$.

* Inocarpus fagifer (Parkinson) Fosberg

Intsia bijuga (Colebr.) Kuntze

e Kingiodendron platycarpum B.L. Burtt Maniltoa grandiflora (A. Gray) Scheffer Milletia pinnata (L.) Panigrahi

Mucuna gigantea (Willd.) DC.

Ormocarpum orientale (Spreng.) Merr.

* Pueraria lobata (Willd.) Ohwi

Schleinitzia insularum (Guillemin) Burkart

e Serianthes vitiensis A. Gray

Tephrosia purpurea (L.) Pers.

Vigna marina (Burm.) Merr.

LOGANIACEAE

Geniostoma vitiense Gilg \& Benedict

LYTHRACEAE

Pemphis acidula J.R. \& G. Forst.

MALPIGIACEAE

e Hiptage myrtifolia A. Gray

MALVACEAE

Hibiscus tiliaceus L.

* Sida rhombifolia L.

Thespesia populnea (L.) Solander

Urena lobata $\mathrm{L}$.

MELASTOMATACEAE

e Medinilla ovalifolia (A. Gray) A.C. Sm.

Memecyclon vitiense A. Gray

MELIACEAE

e Aglaia vitiensis A.C. Sm.

Dysoxylum mollissimum Miq.

e Dysoxylum seemannii Gillespie

Vavaea amicorum Benth.

Xylocarpus granatum Koenig

MOLLUGINACEAE

Mollugo pentaphylla $\mathrm{L}$.

MORACEAE

e Ficus barclayana (Miq.) Summerhayes

e Ficus masonii Horne ex Baker

Ficus obliqua Forst. f.

e Ficus pritchardii Seem.

Ficus tinctoria Forst. f.

e Ficus vitiensis Seem.

Trophis scandens (Lour.) Hook. \& Arn.

MYRISTICACEAE

e Myristica chartacea Gillespie MYRSINACEAE

e Embelia deivanuae R.O. Gardner

e Maesa persicifolia A. Gray

Myrsine myricifolia A. Gray

MYRTACEAE

Decaspermum vitiense (A. Gray) Niedenzu

Eugenia reinwardtiana (B1.) DC.

Metrosideros collina (J.R. \& G. Forst.) A. Gray

Syzygium corynocarpum (A. Gray) C. Muell.

e Syzygium gillespiei Merr. \& Perry

e Syzygium gracilipes (A. Gray) Merr. \& Perry

* Syzygium malaccense (L.) Merr. \& Perry

Syzygium neurocalyx (A. Gray) Christophersen

Syzygium richii (A. Gray) Merrill \& Perry e Syzygium rubescens (A. Gray) C. Muell.

e Syzygium seemannianum Merr. \& Perry

NYCTAGINACEAE

Boerhavia glabrata B1.

NYCTAGINACEAE ctd

Pisonia grandis $\mathrm{R}$. Br.

OLACACEAE

Ximenia americana $\mathrm{L}$.

OLEACEAE

Chionanthus vitiensis (Seem.) A.C. Sm.

Jasminum didymum $\mathrm{G}$. Forst.

PEPEROMIACEAE

Peperomia blanda Kunth

e $P \quad$ eperomia lasiostigma C. DC.

PIPERACEAE

Piper puberulum Benth

PITTOSPORACEAE

Pittosporum brackenridgei A. Gray

Pittosporum rhytidocarpum A. Gray

PORTULACACEAE

Portulaca samoensis Poelln.

RHAMNACEAE

Alphitonia franguloides A. Gray

Alphitonia zizyphoides (Spreng.) A. Gray

Colubrina asiatica (L.) Brongn.

Rhamnella vitiensis (Benth.) A.C. Sm.

Smythea lanceata (Tul.) Summerhayes

Ventilago vitiensis A. Gray

RHIZOPHORACEAE

Bruguiera gymnorrhiza (L.) Lam.

Rhizophora stylosa Griffith

RUBIACEAE

Antirhea inconspicua (Seem.) Christophersen

Badusa corymbifera (Forst. f.) A. Gray

e Dolicholobium oblongifolium A. Gray

e Gardenia grievei Horne ex Baker

Guettarda speciosa L.

e Guettarda wayaensis R.O. Gardner

Hedyotis lapeyrousii DC.

e Ixora vitiensis A. Gray

e Mastixiodendron flavidum (Seem.) A.C. Sm.

Morinda citrifolia L.

Morinda myrtifolia A. Gray

Mussaenda raiateensis J.W. Moore

e Ophiorrhiza laxa A. Gray

e Ophiorrhiza peploides A. Gray

e Psychotria amoena A.C. Sm.

e Psychotria tephrosantha A. Gray

e Psychotria volii R.O. Gardner

Psydrax odorata (G. Forst.) A.C. Sm. \& S.P.

Darwin

Tarenna sambucina (G. Forst.) Durand ex Drake RUTACEAE

Euodia hortensis J.R. \& G. Forst.

Melicope cucullata (Gillespie) A.C. Sm.

Micromelum minutum (Forst. f.) Seem.

SANTALACEAE

Santalum yasi Seem.

SAPINDACEAE

Arytera brackenridgei (A. Gray) Radlk.

e Cupaniopsis leptobotrys (A. Gr.) Radlk.

Dodonaea viscosa (L.) Jacq.

Elattostachys apetala Radlk.

Guioa rhoifolia (A. Gray) Radlk.

* Pometia pinnata J.R. \& G. Forst.

Sapindus vitiensis A. Gray

SAPOTACEAE

Burckella richii (A. Gray) Lam

e Manilkara vitiensis (H.J. Lam \& B. Meeuse 
e Palaquium fidjiense Pierre ex Dubard Planchonella garberi Christopherson

e Planchonella smithii (van Royen) A.C. Sm. Planchonella tahitensis (Nadeaud) Pierre ex Dubard SOLANACEAE

Solanum americanum Mill.

Solanum vitiense Seem.

STERCULIACEAE

Heritiera littoralis Ait.

Kleinhovia hospita L.

e Melochia degeneriana A.C. Sm.

THYMELAEACEAE

Phaleria disperma (Forst. f.) Baill.

e Phaleria ixoroides Fosb.

e Phaleria lanceolata (A. Gray) Gilg

Wikstroemia coriacea Seem.

TILIACEAE

Grewia crenata (J. R. \& G. Forst.) Schinz \& Guillaumin

Trichospermum richii (A. Gray) Seem.

* Triumfetta rhomboidea Jacq.
ULMACEAE

Parasponia andersonii (Planch.) Planch. Trema cannabina Lour.

URTICACEAE

Boehmeria virgata (Forst. f.) Guillemin

Cypholophus heterophyllus (Wedd.) Wedd.

Dendrocnide harveyi (Seem.) Chew

Leucosyke corymbulosa (Wedd.) Wedd.

Pipturus argenteus (Forst. f.) Wedd.

Procris pedunculata (J.R. \& G. Forst.) Wedd.

VERBENACEAE

Clerodendrum inerme (L.) Gaertn.

e Premna protrusa A.C. Sm. \& S. Darwin

Premna serratifolia $\mathrm{L}$.

Vitex trifolia $\mathrm{L}$.

VIOLACEAE

Agatea violaris A. Gray

Rinorea benghalensis (Wall.) Kuntze

VITACEAE

e Tetrastigma vitiense (A. Gray) A.C. Sm. 


\title{
Charles De Kempeneer (c.1852-1884), preparator: one of Auckland Museum's earliest employees
}

\author{
B.J. Gill Associate Emeritus, Auckland War Memorial Museum
}

\begin{abstract}
Henry Ward, the American businessman and trader in natural history specimens, visited Auckland Museum in 1881 and subsequently helped the museum to recruit a preparator. Correspondence between Ward and the museum's curator, Thomas Cheeseman, shows that the first preparator sent by Ward was the Belgian, Charles De Kempeneer, who had worked previously for about seven years at both the "Royal Museum", Brussels, and at Ward's establishment in Rochester, New York State. De Kempeneer started at Auckland Museum in July 1882 for a trial period of about three months until October 1882, the museum having insufficient funds to pay him for longer. He then got work with the Macleay collection in Sydney (Australia) but negotiated with Cheeseman a permanent position at Auckland Museum, whose finances had been improved by the Costley Bequest of 1884. De Kempeneer returned to Auckland to commence work but died on arrival, a tragic loss of a talented young man. By virtue of his short-term engagement, De Kempeneer ranks as one of Auckland Museum earliest employees and the museum's archival record of the Cheeseman correspondence has enabled a memory of him to be recovered.
\end{abstract}

\section{KEYWORDS}

Henry Ward, Thomas Cheeseman, William Macleay, museum history, biography, taxidermy, New Zealand, Australia.

\section{INTRODUCTION}

Thomas Frederic Cheeseman (1845-1923) was curator of Auckland Institute and Museum from 1874 until his death, and was responsible for greatly developing and professionalising the organisation. For much of this time Cheeseman was assisted only by a caretaker-janitor and the museum could afford to employ no other staff. Cheeseman's priority for a second professional position at Auckland Museum was for a taxidermist. After a donation from a benefactor and some special fund-raising, the museum was able to employ Andreas Reischek as taxidermist for part of the period 1880-1881 (Gill 2008). The museum's Annual Report for 1882-83 (Anon. 1883: 7) gave indication of a second, but unnamed, preparator:

"From [want of funds] it has been impossible to retain the services of a taxidermist, and with the exception of a temporary engagement with a competent osteologist [italics added], through which a few excellently prepared skeletons have been added to the collections, little has been done towards working up the large number of specimens received by exchange during the last few years, and now lying packed away in drawers".
H.A. (Henry) Ward, a natural history collector and dealer from Rochester, New York State, visited Auckland in 1881 and met Cheeseman. Ward was well known as an advisor to museums (Kohlstedt 1980, 1985), and his correspondence with Cheeseman shows that he undertook to help recruit from America a taxidermist for Auckland Museum. He recommended the Belgian, Charles De Kempeneer (Figs 1 and 2), who had been working at Ward's establishment for many years. Cheeseman, with limited funds, was able to employ De Kempeneer for a few months in 1882. De Kempeneer then got work in Sydney. Meanwhile, Auckland Museum received the Costley Bequest and Cheeseman negotiated to employ De Kempeneer on a full-time permanent basis. The young man returned to Auckland early in 1884 but died before he could take up his job at Auckland Museum. Ward then recommended another experienced taxidermist from his own establishment. This was Charles Francis Adams who started work at Auckland Museum in January 1885 (Gill 2014).

The purpose of this paper is to record details of the employment of De Kempeneer at Auckland Museum and to restore knowledge of him to the museum's memory. 

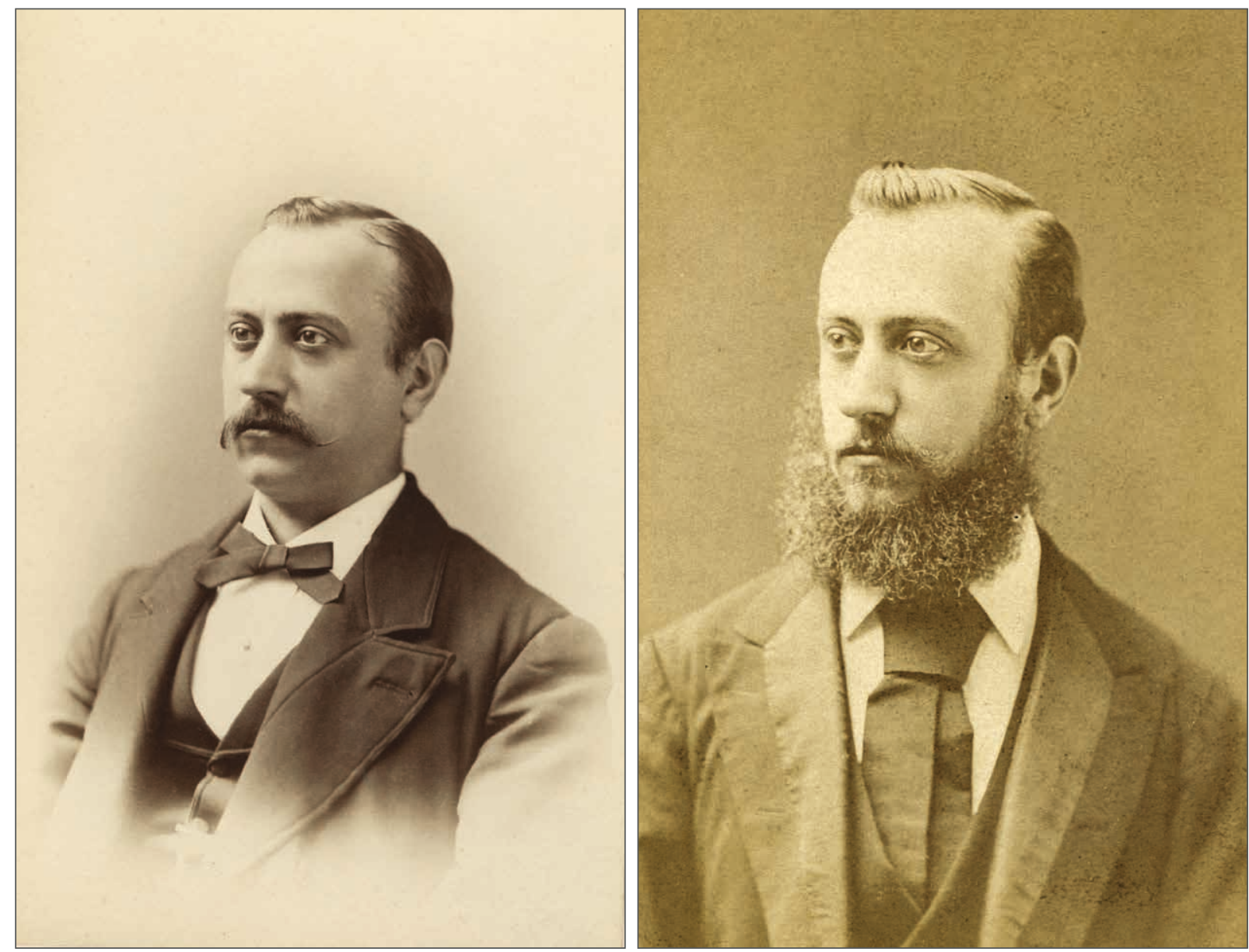

Figure 1. Two studio portraits of Charles De Kempeneer presumably taken around 1875 to 1882 while he was employed at Ward's Natural Science Establishment, Rochester, New York State. Photos: Ward Project, Rush Rhees Library, University of Rochester.

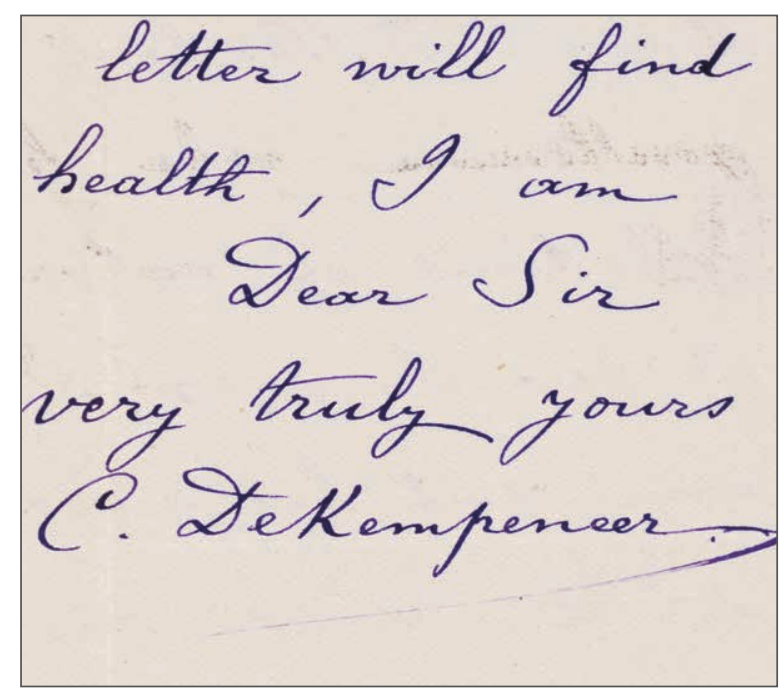

Figure 2. Charles De Kempeneer's hand-writing and signature from one of his letters to Thomas Cheeseman (MUS-1995-38-70).

\section{MATERIALS}

Auckland Museum's Annual Report recorded minimal indications of De Kempeneer's employment and supplied no name. Instead, his identification and details of his employment in Auckland were discovered principally from manuscript collections in Auckland Museum Library (ZAR). MUS-1995-38-70 has seven letters from Charles De Kempeneer to Cheeseman written (in English) from Sydney. It also has two letters from Charles De Kempeneer's father (P. De Kempeneer) to Cheeseman written (in French) after his son's death. MUS-199538-158 has letters from H.A. Ward to Cheeseman, five of which mention Charles De Kempeneer. MUS-1996-6 (letter-books) has copies of four letters from Cheeseman to Charles De Kempeneer and three letters from Cheeseman to Ward that mention De Kempeneer.

The Ward Project (wardproject.org) of the Rush Rhees Library (University of Rochester, N.Y., U.S.A.) has 18 letters from Charles De Kempeneer to H.A. Ward, written (most in French) between 1880 and 1884 from Rochester, Berlin, Brussels, New York, San Francisco, Sydney and Melbourne. There is also one letter from Charles De Kempeneer's father to H.A. Ward (June 1884; in French). 


\section{SHORT ENGAGEMENT IN AUCKLAND, 1882}

In 1881 H.A. Ward set out on a year-long collecting tour to Australasia and South-east Asia (Anon. 1881). He sailed from San Francisco on 14 February 1881 and reached Auckland on 9 March to spend about a month in New Zealand before proceeding to Australia. Ward met Cheeseman at Auckland Museum, and understanding the museum's need for a taxidermist was able to recommend one of the young staff members of his own establishment who was keen to travel. After returning home, Ward wrote to Cheeseman on 24 May 1882 (MUS-1995-38-158):

"Eight years ago when at Brussels the Director of the Royal Museum there [now Royal Belgian Institute of Natural Sciences] gave me a very high recommendation of a young man - Charles De Kempeneer - who had been in their Museum for 7 years engaged in work upon skeletons. Seeing his work and liking it, I then and there (with the Director's assent) engaged $\mathrm{Mr}$ De Kempeneer to come with me to America. He has now been with me for seven years as a trusted and valuable Employi $[$ sic]. His work has been mainly mounting skeletons of all kinds and of all sizes, both with natural and with artificial ligaments. At this he has extraordinary ability - making most beautiful preparations. ...

I naturally want to keep him with me. But he has long had in mind visiting Australia. I have postponed him for a year and now let him go reluctantly (for my own interests), yet cheerfully as a long-tried, faithful workman. I am anxious that he shall find friends and a good position promptly after reaching your country. Do you not want him for a longer or shorter engagement at your flourishing Museum? He will mount your skeletons (Moas included) and put up Crustaceans or other things requiring skill and nice manipulation in an excellent manner. He has been stuffing a few mammals lately, and is already an average taxidermist with assurance of excelling with practice.

If you need an assistant for work as above mentioned I can most heartily and unqualifiedly recommend to you (for skill and for character) Mr. Charles De Kempeneer. I think that he will follow by next steamer to [the] one taking this letter, and he will (I so advise him) get off at Auckland to try a little of New Zealand. He will call on you, and this letter I send ahead as his introduction."

De Kempeneer arrived in San Francisco on 14 June 1882 (De Kempeneer to H.A. Ward, 17 June 1882, Ward Project), where he attempted to acquire seals and other specimens for Ward. He sailed for Auckland on 1 July 1882 (De Kempeneer to H.A. Ward, 1 July 1882, Ward Project) and would have arrived later that month. On 26 August 1882 a local newspaper (N.Z. Herald issue 6482: 5) reported that:

"Mr. T. F. Cheeseman has had mounted the skeleton of a python, which is set out on a black ground and shown to great advantage. The preparation and mounting has been very artistically performed by M. De Kempeneer, osteologist, at present on a flying visit to Auckland."

The python was said to be 12.5 feet long $(3.8 \mathrm{~m})$. I realise now that this was the derelict item I discovered in a disused stairwell at Auckland Museum in 1984 (Gill 2016: 6). The skull and a selection of vertebrae and ribs were saved (LH644, Figs 3 and 4). The snake (Python sebae from West Africa) had been received on exchange from the Muséum National d'Histoire Naturelle (Paris) in 1878 , probably as a roughed-out dry skeleton that De Kempeneer had to macerate and clean as well as articulate and mount.

In reply to Ward's letter of 24 May 1882, Cheeseman wrote on 9 September 1882 (MUS-1996-6-2: 44):

"I noted your remarks about $\mathrm{Mr}$ de Kempener [sic]. I have given him a short engagement, but fear that our funds will not allow me to keep him long. I like his work very much."

On 12 October 1882 the N.Z. Herald (issue 6522: 4) reported that the S.S. Rose Casey had arrived in Auckland with a swordfish 12 feet long $(3.7 \mathrm{~m})$ including the "sword". "Captain Somerville at once sent the monster to the museum, where it will be prepared for exhibition by M. de Kempeneer." On 14 October 1882 (MUS-199538-158), Ward wrote to Cheeseman:

"I am glad that you gave Mr. De Kempeneer a trial. $\mathrm{He}$ is a first-class Osteological workman. I write him by this mail offering him an increase of salary and advance of money for his passage if he will come back to me for 2 or 3 years."

\section{NEGOTIATIONS WHILE AT SYDNEY}

With no further paid work in New Zealand, De Kempeneer moved to Australia. He reached Sydney on 6 November 1882 and wrote to Cheeseman on the 29th (MUS-199538-70). De Kempeneer called on Edward Pierson Ramsay (1842-1916), curator of the Australian Museum, seeking work. "I saw Mr Ramsay and gived [sic] him your Kind letter, and after reading it, he said that he was willing to give me work about the $1^{\text {st }}$ of January next, that he could not get money before that time, but that if I wished to have some work before, that I could go and see the Hon. Wm. Macleay, a wealthy gentleman who has some large collections of natural history. A few days ago I saw that gentleman and he gived [sic] me some work, at £4-0-0 a week, which is rather good, considering that I have to work only 39 hours a week." William Macleay's family collection is now the Macleay Museum of the University of Sydney (Stanbury \& Holland 1988, Stacey \& Hay 2007). De Kempeneer was at a boarding house at 109 William Street, Woolloomooloo. He liked Sydney but found the sun rather hot.

De Kempeneer had no reply from Cheeseman, so wrote again on 21 March 1883 (MUS-1995-38-70). 


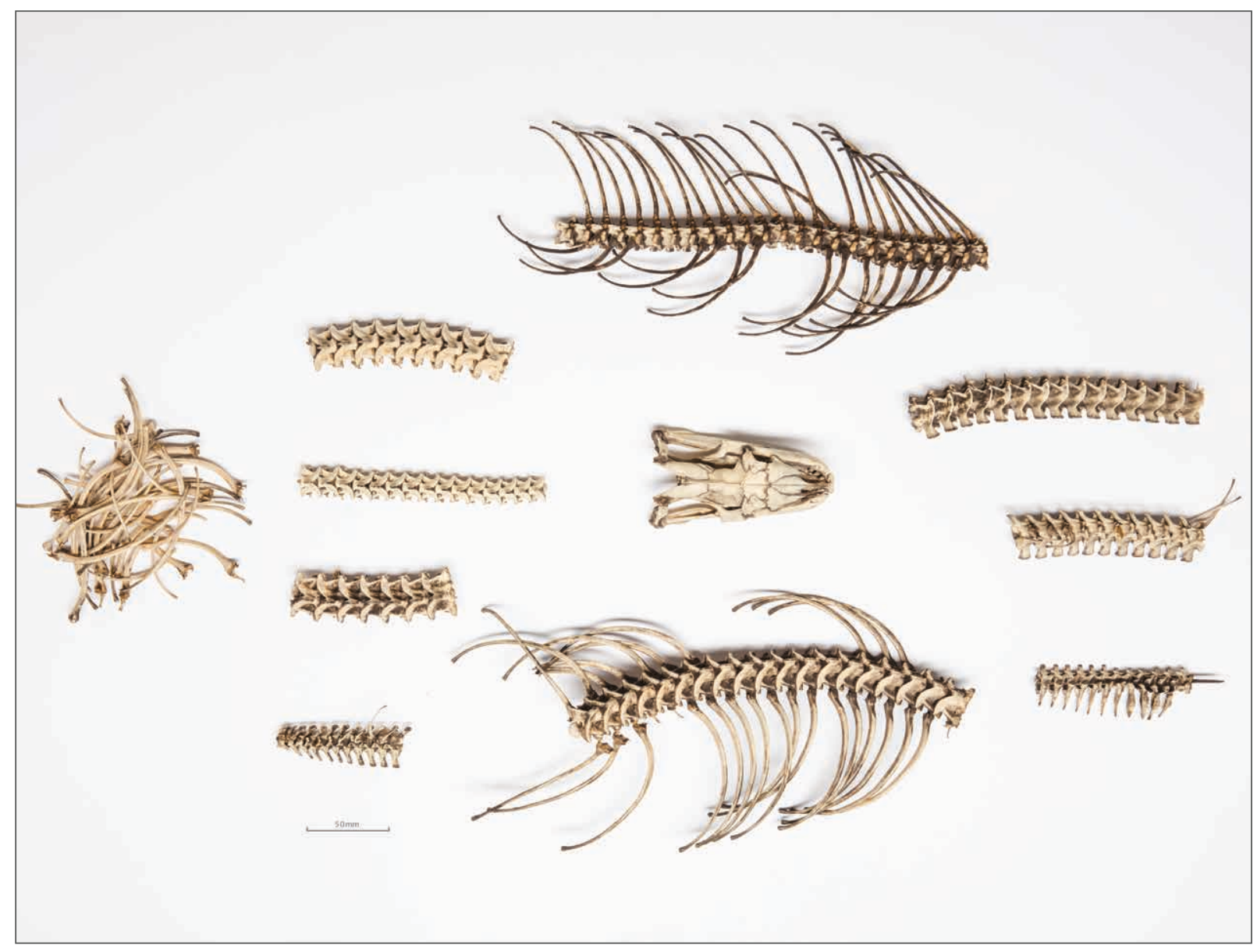

Figure 3. Surviving bones from the skeleton of a $3.8 \mathrm{~m}$ python (LH644) that De Kempeneer mounted for display at Auckland Museum in 1882. It was assembled originally in a sinuous shape, the snake viewed dorsally but elevated (tilted 90 degrees) onto a vertical black board.

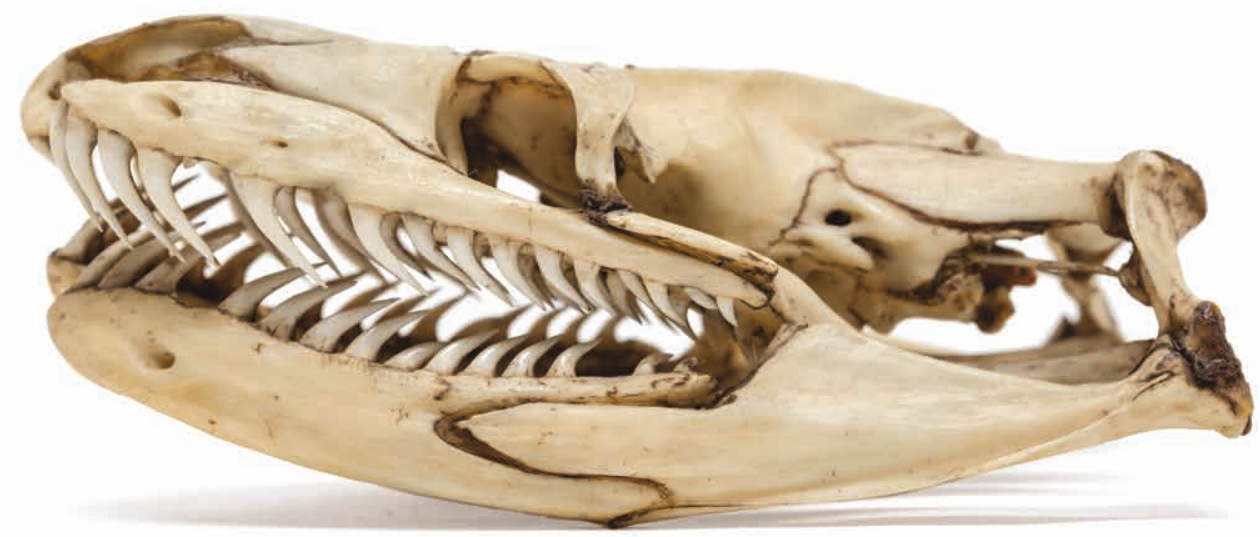

Figure 4. Skull of the python (LH644) that De Kempeneer prepared. 
"I am still working for the Hon. Wm. Macleay, and the prospects are that I will have work there for quite a while yet. I have stuffed a large Cervus Canadensis [deer] and an American rocky mountain sheep, and Mr Macleay is much pleased with it.

Mr Ramsay is gone to Europe as representative of N.S.W. at the International Fisheries Congress, and also to visit the different large Museums of Europe to find out which are the best glass cases for specimens. The governement $[$ sic $]$ has voted four thousand pounds to renew all the glass cases in the Sydney Museum. Mr Ramsay told me that he expects to stay away about five months and intends to come back by the way of America, and said that I would probably not have a billet [i.e. appointment] at the Museum before he gets back. Since he has gone I heard that the governement [sic] has given him 9 months leave of absence.

Prof. Ward has written to me several letters and wishes me to go back to Rochester for a three years engagement. I have not accepted [h] is offer because I wish to stay several years in these colonies.

In December last I had an other [sic] offer. The Director of the Hobart Town Museum (Tasmania) had written to Mr Ramsay and asked to send him a taxidermist to stuff a collection of fishes for the London Exhibition. Mr Ramsay thought that gentleman would hardly pay me the same as I have here and was not willing to pay my passage neither [sic], so I naturally refused.

Please be kind enough to write me a few lines to know how prospects are at the Auckland Museum."

Cheeseman wrote on 9 July 1883 (MUS-1996-6-2: 118):

"Since I last wrote you the Institute has been bequeathed a large sum of money - probably nearly $£ 10,000$. We have not yet received it, for the estate has to be wound up, the property sold, etc, and this will take a few months."

This was a bequest of $£ 12,150$ from Mr Edward Costley that the museum received in 1884 (Powell 1967: 80).

Cheeseman continued:

"If you are still disengaged, you might write me a line or two stating what salary you would expect for an engagement as taxidermist and osteologist to the Auckland Museum. I do not think that it will now be long before we are in a position to employ a properly qualified person, and I should like to know what your terms are before making an actual recommendation to our committee. In any case I hope you will not take a permanent situation in Australia until after you have written to us on the question. I have not yet brought the matter before our committee, but will do so as soon as I receive your reply."

De Kempeneer was pleased at this news, and replied on 31 July 1883 (MUS-1995-38-70). “About taking an engagement to the Auckland Museum I have thought that matter over and as I suppose that you will need a permanent person I would be willing to go back to Auckland to teach such person during about twelve months at $£ 25$ a month. Should I be accepted at those terms I could not possibly be in Auckland before the end of this year or the beginning of the next. If possible [I] would like to receive an answer within two months." On 5 September 1883, De Kempeneer wrote to Ward about shark specimens but also copied out Cheeseman's letter verbatim. He told Ward he was happy in Sydney and reluctant to return to Auckland which he found more expensive than Sydney and lacking in amusements (De Kempeneer to H.A. Ward, 5 September 1883, Ward Project).

Cheeseman made a counter-proposal (4 September 1883; MUS-1996-6-2: 145).

"About taking an engagement at our Museum. I should much like to arrange with you, but I don't think the plan you propose - to teach a person for say 12 months at a salary of $£ 25$ per month - would suit our views[?]. In the first place, I don't suppose that a likely person would come to be taught unless he was also paid a salary, and that, in addition to your own, would make it very expensive to us - in fact would make the cost more than we could afford, unless we starved other departments. Then again, $£ 26$ per month (or $£ 300$ per annum) is a rather large salary compared to what the other taxidermists in the Colony are receiving. My views in writing you were these. That perhaps we might obtain your services (alone) at about the same salary that is paid at the other Museums in the Colony, which I believe is from $£ 200$ to $£ 225$; or, if you were indisposed to take a permanent engagement, that we might have engaged you for a year or two until we could get someone from England or America. I have not put the matter before our committee, for unless it could be put into some shape similar to the above, I don't well see what we could do. But I should be glad to hear further from you on the Subject. It will probably be six months before we are in possession of funds to do anything."

De Kempeneer (now at 191 William St., Woolloomooloo) replied to Cheeseman on 3 October 1883 (MUS-1995-38-70).

"I would have written sooner but all this time have been so undecided about what to do, all on account of prospects here being rather good, however as I now have decided to remain in Australasia longer than I at first thought of staying I have decided to accept an engagement at the Auckland Museum for 2 or 3 years or perhaps longer, at $£ 240$ per year and work 44 hours per week or if the Institute could not afford to pay such a salary would be willing to do it for $£ 225$ per year but then work as I actually do here 38 hours per week, and also would want to work alone." 
Cheeseman replied promptly (29 October 1883, MUS-1996-6-2: 155).

\begin{abstract}
"I received your letter some little time back, and it was considered at a meeting of our committee held the other day. The proposal you make - to accept an engagement for a period at the rate of $£ 240$ per annum - was considered to be more within the means of the Institute than your previous idea of working with an assistant, and I think that the committee are favourably inclined towards it. But it was not possible to come to a decision at that meeting, as we are still somewhat in the dark as to when we shall receive our share of the bequest made by $\mathrm{Mr}$ Costley, although it cannot be [?]long. I was requested to write and ask you when you could come to Auckland provided it was decided to engage you. In asking this I should say that we shall probably not be ready at the end of the year - although I think we shall be by March or April. You might send me a line by the return of mail, and it would probably be in time for the next committee meeting, to be held about the middle or later part of November. At this meeting the matter will be again discussed."
\end{abstract}

De Kempeneer wrote back on 6 November 1883 (MUS-1995-38-70).

“... I was somewhat surprised that the committee had not yet come to a definite conclusion with reference to my proposal, as it is necessary that I should give due notice to my present employer, and as I would like, if possible, to visit those Australian colonies that I have not yet visited, I would feel extremely obliged if they would come to a decision as soon as possible."

He could be in Auckland in March or April after a visit to other colonies.

Cheeseman concluded the arrangements on 14 December 1883 (MUS-1996-6-2: 166).

\begin{abstract}
"I am now to inform you that the committee will accept your offer of an engagement at the rate of $£ 240$ per annum, working 44 hours per week. The engagement would be for one year certain, after which three months notice might be given by either side. In reference to this, I should say that it is our intention to employ a taxidermist permanently, so that in all probability we should wish to keep you much longer than the year, if you yourself were agreeable. The engagement might commence any time after April 1st next [1884], before which time we could hardly be ready."
\end{abstract}

De Kempeneer was pleased (2 January 1884, MUS-1995 $-38-70)$.

“... I will now be in a position to tell to Mr Macleay, (as soon as I see him), the precise time I shall have to leave Sydney. Please accept my best thanks for your kindness and courtesy and also for your exertions on my behalf."

He continued:

"I need hardly say that it will be my constant endeavour to give entire satisfaction and to advance the interests of the Museum. I entirely consent with the conditions stated in your letter. They are liberal, and will suit me nicely. In order that I might not incommode Mr Macleay (who has at present a large number of specimens on hand, sufficient to keep a taxidermist constantly employed for some months at least) I have resolved not to leave Sydney before the middle or latter part of April. I shall therefore, in all probability, be in Auckland by the $1^{\text {st }}$ of May. In consequence of this, I have determined to forego my trip around N.Z., etc, for the present however."

The situation changed, and by the end of the month (De Kempeneer to H.A. Ward, 30 January 1884, Ward Project) Macleay had indicated that he wanted no more specimens prepared as there was no space at the museum to store them. De Kempeneer had about three months before he was due in Auckland and resolved:

“... in about ten days I expect to sail for Melbourne, then Tasmania and New Zealand, where I expect to visit the main towns and the hot springs ...".

He left Sydney on 15 February 1884 and reached Melbourne on the 17 th, expecting to sail for Tasmania around 4 March (De Kempeneer to H.A. Ward, 27 February 1884, Ward Project).

Auckland Museum's Annual Report for 1883-84 (Anon. 1884: 7) expected a happy outcome from the De Kempeneer negotiations:

"In anticipation of an increased revenue,
arrangements have been made for the employment
of a permanent taxidermist; and a thoroughly
competent workman has been selected, and in a few
months will arrive in Auckland".

The last letter from De Kempeneer in the Auckland Museum archive (6 February 1884, MUS-1995-38-70), however, was short and ominous. He reported that during the last few weeks he had not been in very good health, but: "I think that a change of air will do me good, and, expect to be ready for work by the first of May next [1884]".

\section{RETURN TO AUCKLAND, 1884}

On 19 April 1884, in a section headed "Local Gossip", the N.Z. Herald (issue 6996, suppl.: 1) carried a detailed but anonymous tribute to the Belgian preparator:

"I opened my paper the other morning and was startled and made inexpressibly sad by seeing the announcement of the death of poor M. de Kempeneer. ... I believe I am the only one here 
[Auckland] who knew him intimately. ... I bade him bon voyage fifteen months ago on his departure for Sydney [that would be January 1883 , but in fact De Kempeneer reached Sydney in November 1882] ... For some short time before he left for Sydney he was engaged at the Auckland Museum preparing specimens. He was an osteologist by profession, and possessed great skill and experience, partly acquired in Brussels, his native place, and partly in America ... Unfortunately he found his services here of no use by reason of the impecunious condition of the various colonial museums. His abilities and high testimonials were appreciated by all competent to judge of them, but "no funds" was the answer he got wherever he applied. It was the same in Sydney. But Baron Macleay found him out, and for some time he was engaged in arranging and fixing his large and valuable collection of natural history. The intense heat, however, was too much for him. After wandering about Australia he returned to New Zealand, and the Auckland Museum being at last in funds, was returning to resume his duties here, when his health gave way, and he reached Auckland only to expire. ... He had a passion for travel, and it was his intention to visit Japan, China, and India before returning to Belgium. ... He was a quiet and singularly unobtrusive man, a most pleasant companion, and altogether a good fellow."

On 24 or 28 April 1884 (second day-numeral illegible), Cheeseman wrote to Ward (MUS-1996-6-2: 198-201):

"I have sad news to tell you about poor De Kempeneer. As you know, we had offered him a year's engagement in the Museum, and he was to have been here in time to commence work on May $1^{\text {st }}$. He left his engagement in Sydney some time back, intending to spend some time in Australia \& the southern part of New Zealand, travelling. He reached Dunedin all right, but was taken ill there, but not thinking much of it, took his passage to come on to Auckland. He got rapidly worse during the voyage, and when the steamer arrived was in a nearly comatose state. The Steward of the boat took him up to the Hospital, and a message was sent to me asking me to come and see him. Unfortunately I had just left the Museum for the day, and heard nothing of it until the following morning - when it was too late, as he died during the night. Poor fellow - I have felt very sorry for him, dying alone and among strangers. The cause of his death was acute inflammation of the kidneys. We found nothing among his effects giving a clue to the address of his friends in Belgium; so that if you know this I should be extremely obliged if you would write and tell them the sad news."

His death certificate shows that Charles De Kempeneer died on 8 April 1884 at Auckland Hospital, aged 32 years (entry 244 in register of deaths for Auckland District during the quarter ending 30 June 1884; scan provided by Department of Internal Affairs
25 July 2018). The cause of death was “Acute Bright's Disease" (nephritis) and he was given a Church of England burial on 10 April by Rev. J. Shanahan. He was listed as having a personal estate under $£ 50$ in the "Notice of estates of deceased persons placed under the charge of the Public Trustee in April" (N.Z. Herald issue 7024: 4, 22 May 1884). His belongings were advertised for auction by Samuel Cochrane \& Son (Auckland Star issue 4363: 4, 13 May 1884): "Estate of De Kempeneer (deceased): Taxidermist's tools and utensils, trunk clothing, portmanteau and clothing, watches, globes, fancy goods".

A few months after the death, Cheeseman received a letter (dated 12 June 1884; MUS-1995-38-70) from Charles' father, Monsieur P. De Kempeneer of 32 rue Botanique, Bruxelles (Nord), an attaché in the Belgian Interior Ministry. He explained (translated from French):

"Professor Ward of Rochester, told me the sad news
of the death of my beloved son Charles, who was
engaged to work under your direction as natural
history preparator at Auckland Museum. You will
understand how much this news has distressed us,
both me and all my family."

The father continued:

"If this does not stretch your kindness, I will allow myself, professor, to ask you to tell me what of, and how, my unfortunate son died. It would please me to know if he was cared for in his last moments and by whom and how he has been buried."

Unfortunately, a copy of Cheeseman's reply has not been found in the Letter-books. P. De Kempeneer wrote again to Cheeseman on 11 July 1884 (MUS-1995-3870), saying (translated from French):

\begin{abstract}
"We can't, my family and me, thank you enough, and for the big part that you take in the cruel loss that we have just had, and for the effort that you have given us in attending to the funeral of our missed Charles, in making sure that all went properly".
\end{abstract}

\section{DISCUSSION}

In 32 years as Curator of Land Vertebrates at Auckland Museum I can recall no reference to the name Charles De Kempeneer. This was partly because the names of preparators had never been recorded in catalogue records for individual land vertebrates specimens. The brief reference in the 1882-83 Annual Report to the "temporary engagement with a competent osteologist" was a mystery. Then, recently, I studied the correspondence between Cheeseman and Henry Ward, preserved in the Auckland Museum Library, and a full story unfolded of De Kempeneer as a preparator in Auckland. Ward's letters gave the surname and that enabled discovery of the letters from son and father to Cheeseman. 
It is clear now that Charles De Kempeneer was employed at Auckland Museum from July to October 1882. The newspapers show that during this time he mounted a large python skeleton (LH644), and probably worked on a large swordfish (not present in the current collection). He probably worked on other skeletons that survive in the collection, whether collected in 1882 or earlier, but these cannot now be identified. By virtue of this temporary engagement at Auckland Museum, De Kempeneer ranks as one of the institution's earliest employees.

De Kempeneer's death left Cheeseman once again without a taxidermist and in the same letter to Ward giving news of the tragic death (24 or 28 April 1884; MUS-1996-6-2: 198-201) Cheeseman asked Ward to find a replacement (who, as events turned out, was Charles Adams; see Gill 2014). In stating employment terms for the replacement, Cheeseman gave the hours of work, and these presumably would have applied to De Kempeneer's 44 hours per week. "The hours of work would be the same as in the other Museums in the Colony - from 8 to 5, with an hour for dinner, and half a day on Saturdays." "Dinner" in those days was a mid-day meal.

On 9 December 1884 a New Zealand newspaper (Evening Star 6770: 2) had an enigmatic comment:

"I see the New York papers refer mysteriously to the disappearance of a large sum of money supposed to have been in the possession of Mr Charles De Kempeneer, who died recently at Auckland".

The matter had been raised in the Buffalo Courier (Buffalo, N.Y., 19 September 1884: 2). B. Frank Enos, of Rochester, N.Y., had heard of De Kempeneer's early death, and, because De Kempeneer was a member of Rochester Lodge, Enos

"wrote a letter to New Zealand, addressing it to any master, secretary or member of a lodge of Masons located in or about Auckland, inquiring as to whether such a person as Charles De Kempeneer had died at that place".

James Slator, past grand secretary of a North Island lodge, replied from Auckland on 15 August 1884 giving details of De Kempeneer's death and offering to try to recover his Masonic papers. The Buffalo Courier article noted the rumour that De Kempeneer "was in possession of a considerable amount of money". "Whether this money was deposited in a bank at Sydney ... or whether it was with him at the time of his death, is not known".

\section{ACKNOWLEDGEMENTS}

Cited New Zealand newspaper articles were found through the National Library of New Zealand's "Papers Past" website. I thank Severine Hannam (Auckland Museum) for finalising a translation of two letters in French by P. De Kempeneer. I am grateful to Martin Collett and Elizabeth Lorimer (Auckland Museum Library) and Melissa Mead (Rush Rhees Library, University of Rochester, U.S.A.) for assisting me with access to letters, documents and photographs pertaining to Charles De Kempeneer, and for checking a draft of this article.

\section{REFERENCES}

Anonymous, 1881. Foreign tours for the establishment. Ward's Natural Science Bulletin 1(1): 2.

Anonymous, 1883. Annual Report of the Auckland Institute and Museum for 1882-83: 7.

Anonymous, 1884. Annual Report of the Auckland Institute and Museum for 1883-84: 7.

Gill, B., 2016. The Unburnt Egg. More Stories of a Museum Curator. Wellington: Awa Press.

Gill, B.J., 2008. Chap. 2. Ornithology at Auckland Museum, New Zealand. Pp. 121-164. In: Davis, W.E., Recher, H.F., Boles, W.E. and J.A. Jackson (eds). Contributions to the History of Australasian Ornithology. Cambridge, MA, Nuttall Ornithological Club.

Gill, B.J., 2014. Charles Francis Adams: diary of a young American taxidermist visiting New Zealand, 1884-1887. Archives of Natural History 41: 1-16.

Kohlstedt, S.G., 1980. Henry A. Ward: the merchant naturalist and American museum development. Journal of the Society for the Bibliography of Natural History 9: 647-661.

Kohlstedt, S.G., 1985. Henry Augustus Ward and American museum development. The University of Rochester Library Bulletin 38: 21-37.

Powell, A.W.B., (ed.) 1967. The Centennial History of the Auckland Institute and Museum. Auckland: Auckland Museum.

Stacey, R. and A. Hay, 2007. Museum: the Macleays, their Collections and the Search for Order. Melbourne: Cambridge University Press.

Stanbury, P. and J. Holland, 1988. Mr Macleay's Celebrated Cabinet. The History of the Macleays and their Museum. Sydney: University of Sydney. 



\section{Records of the Auckland Museum}

\section{INSTRUCTIONS FOR AUTHORS}

The Records publishes scholarly papers by Auckland Museum staff and research associates, and papers by other authors that are based at least partly on material in the Auckland Museum collections. Submission of a paper is taken to mean that the results reported have not been published or submitted for publication elsewhere. Papers will be refereed.

Manuscripts should be submitted to the Editors (jearly@aucklandmuseum.com (natural sciences topics) or fpereira@aucklandmuseum.com (human history topics) as an email attachment. Manuscripts should be in MS Word 2000 or later, saved as .doc or .docx files, and formatted at A4 size with up to $16 \mathrm{~cm}$ wide text block. Text should be double spaced, Times New Roman 12 pt or equivalent. The first page should show: author name(s) and address(es) plus email address(es), noting author for correspondence, and abstract and keywords if required. Begin the text, References Cited, Figures captions on separate pages. Tables and appendices, with captions above, should also be on separate pages at the end.

Authors must consult volume 50- of the Records to ensure that their manuscript follows the correct layout, conventions and format for sectional headings, tables, captions, references, abbreviations, etc. Manuscripts not submitted in the required format will be returned. An acceptable guide for style, other than recent volumes of the Records, is the New Zealand Government Printing Office Style Book (3rd ed., 1981), or later edition. Nomenclature of organisms must follow the current international codes (e.g. International Code of Zoological Nomenclature, 4th ed., 1999).

Figures should be separate files and not embedded in the text of the submitted manuscript. Do not put captions on Figures. The maximum block size for figures is $165 \mathrm{~mm}$ wide x $220 \mathrm{~mm}$ high. Submit raster or pixel based Figures as TIFF, PSD or High Quality JPEG figures. Black and white line-art should be at least $600 \mathrm{dpi}$ (Dots per inch) at reproduction size. All other raster or pixel images (i.e. digital photographs, scanned artwork etc.) should be at least 300 dpi at reproduction size. Submit vector based illustrations as Macromedia Freehand (FH\#), Adobe Illustrator (AI) or Portable Document Format (PDF) files.

For examples of the referencing style for the Records of the Auckland Museum consult volume 50-.

Abstracts are required for all papers (except Short Notes) and should be informative (by giving principal findings) rather than indicative (by saying what was done). All measurements should be in metric (SI) units, or with metric equivalents given. Entries listed under "References" must be referred to in the text.

Authors are responsible for the accuracy of their data, references and quotations, for their conclusions and remarks, and for correcting proofs. They should ensure they have permission to reproduce any images that are not their own. 